Efeitos das condições metabólicas de vacas leiteiras durante o período de transição e início de lactação sobre a saúde e fertilidade no inverno e no verão 


\section{Efeitos das condições metabólicas de vacas leiteiras durante o período de transição e início de lactação sobre a saúde e fertilidade no inverno e no verão}

Tese apresentada ao Programa de Pós-Graduação em Reprodução Animal da Faculdade de Medicina Veterinária e Zootecnia da Universidade de São Paulo para a obtenção do título de Doutor em Ciências

\section{Departamento:}

Reprodução Animal

Área de Concentração:

Reprodução Animal

Orientador:

Prof. Dr. Ed Hoffmann Madureira

De acordo:

Orientador(a)

Pirassununga-SP

2013 
Autorizo a reprodução parcial ou total desta obra, para fins acadêmicos, desde que citada a fonte.

\section{DADOS INTERNACIONAIS DE CATALOGAÇÃO-NA-PUBLICAÇÃO}

(Biblioteca Virginie Buff D’Ápice da Faculdade de Medicina Veterinária e Zootecnia da Universidade de São Paulo)

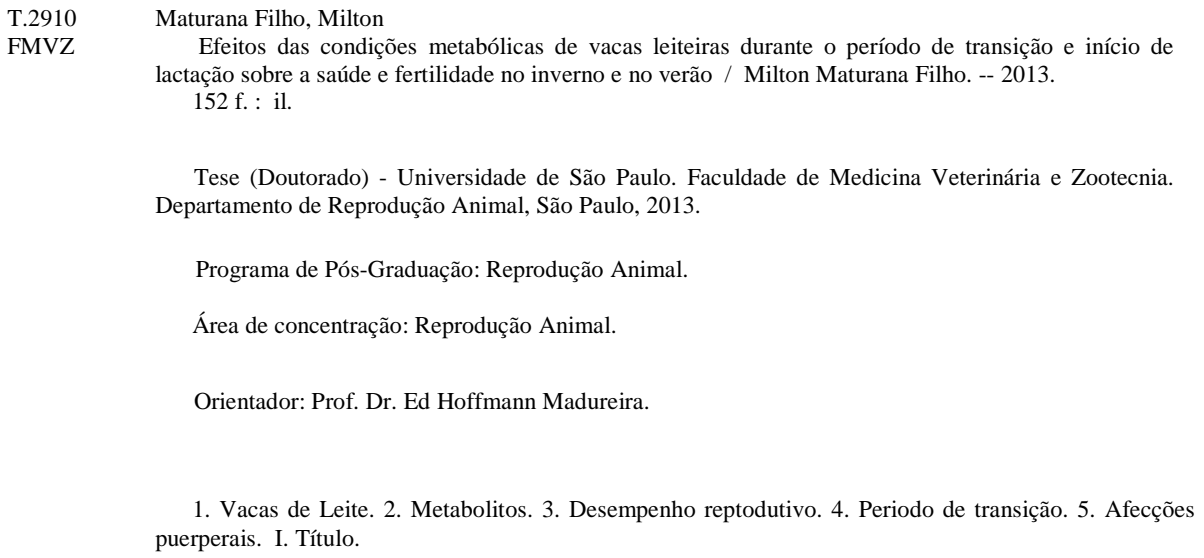

Tese (Doutorado) - Universidade de São Paulo. Faculdade de Medicina Veterinária e Zootecnia. Departamento de Reprodução Animal, São Paulo, 2013.

Programa de Pós-Graduação: Reprodução Animal.

Área de concentração: Reprodução Animal.

Orientador: Prof. Dr. Ed Hoffmann Madureira.

1. Vacas de Leite. 2. Metabolitos. 3. Desempenho reptodutivo. 4. Periodo de transição. 5. Afecções puerperais. I. Título. 


\section{Comissão de Ética no uso de animais}

\section{CERTIFICADO}

Certificamos que o Projeto intitulado "Avaliação da condição metabólica e hormonal de vacas leiteiras durante o período de transição e inicio de lactação no desempenho produtivo e reprodutivo", protocolado sob o no 1896/2010, utilizando 200 (duzentos) vacas leiteiras, sob a responsabilidade do Prof. Dr. Ed Hoffmann Madureira, está de acordo com os princípios éticos de experimentação animal da "Comissão de Ética no uso de animais" da Faculdade de Medicina Veterinária e Zootecnia da Universidade de São Paulo e foi aprovado em reunião de $30 / 06 / 2010$.

We certify that the Research "Evaluation of metabolic and hormonal conditions of dairy cows during the transition period and early lactation on productive and reproductive performance", protocol number 1896/2010, utilizing 200 (two hundred) dairy cows, under the responsibility Prof. Dr. Ed Hoffmann Madureira, agree with Ethical Principles in Animal Research adopted by "Ethic Committee in the use of animals" of the School of Veterinary Medicine and Animal Science of University of São Paulo and was approved in the meeting of day 06/30/2010.

São Paulo, 01 de julho de 2010

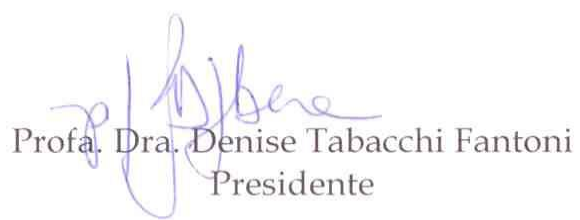




\section{FOLHA DE AVALIAÇÃO}

Nome: MATURANA FILHO, Milton

Título: Efeitos das condições metabólicas de vacas leiteiras durante o período de transição e início de lactação sobre a saúde e fertilidade no inverno e no verão

Tese apresentada ao Programa de Pós-Graduação em Reprodução Animal da Faculdade de Medicina Veterinária e Zootecnia da Universidade de São Paulo para a obtenção do título de Doutor em Ciências

Data:

\section{Banca Examinadora}

Prof. Dr:

Instituição: Julgamento:

Prof.Dr:

Instituição: Julgamento:

Prof.Dr:

Instituição: Julgamento:

Prof.Dr:

Instituição: Julgamento:

Prof.Dr: Julgamento: 
“A sorte não existe. Aquilo a que chamas sorte é o cuidado com os pormenores".

\section{Winston Churchill}

"A REGRA a ser observada neste estábulo, em todas as ocasiões, com relação ao bovino jovem ou idoso, é ter paciência e gentileza. A utilidade de um homem termina quando ele perde seu humor e passa a ter um tratamento rude. Os homens devem ser pacientes. Lembre-se que o oferecimento do leite se trata de Maternidade. Trate cada vaca como se trataria uma mãe. O tratamento áspero diminui o fluxo lácteo. Isso me afeta tanto quanto à vaca. Sempre tenha essas idéias em mente quando lidar com o meu gado. Faça aquilo que gosta e não terá de trabalhar um único dia na sua vida”.

W.D Hoard, 1885

"Ter um objetivo é a chave para alcançares o teu melhor." Henry J. Kaiser

"As oportunidades nunca são perdidas. Alguém sempre vai aproveitar as que você perdeu” 


\section{Dedicatória}

Dedico a Deus e a Jesus Cristo, por me dar saúde, discernimento, força e a paz, necessárias para passar por mais esta etapa de minha vida. Tudo que eu conquistar, que seja para o bem das pessoas e dos animais, mas acima de tudo, para exaltar o teu Santo nome!!! "O principio da ciência é o temor a Deus; Bem aventurado o homem que acha sabedoria e o homem que adquire conhecimento" (PV 1:7a/2:13)

Dedico esta conquista, a minha mãe, Tereza Salvático de Paula, meu grande exemplo de dedicação, esforço e amor. Obrigado pela educação concedida, pelo grande apoio para que eu conseguisse chegar até no Doutorado. "Tudo aquilo que sou, ou pretendo ser, devo a um anjo, minha mãe" (Abraham Lincoln). Dedico também ao meu pai e grande amigo, Milton Maturana, que me ensinou e incentivou a cuidar de animais desde a minha infância. Hoje sei o quanto os animais são importantes e como podem trazer alegria na nossa vida. Saiba que os exemplos de vocês, sempre me ajudam a lutar para honrar com os meus objetivos e compromissos.

Dedico aos meus irmãos Francisco Alexandre de Paula Maturana e a Mirian de Paula Maturana, pelo apoio e amor, durante toda minha vida, pela compreensão, pelos momentos tolhidos, pelo auxílio na busca do meu crescimento profissional e pessoal e por serem sempre presentes nos meus anseios, mesmo que às vezes eu esteja distante por causa do trabalho.

Dedico a minha avó Alcídia Salvático de Paula (in memorian), por ter me educado e por sempre ter sido um grande exemplo de dedicação e amor a minha família.

Dedico a três professores: Ed Hoffmann Madureira, Elias Tunon Vilarreta e José Ricardo Mesquita (Cal), que foram fundamentais em várias escolhas que fiz e que me ajudaram a enxergar o grande valor da profissão do médico veterinário, além disso, também me incentivaram a estudar, trabalhar e pesquisar sobre reprodução animal.

Dedico as vacas Leiteiras, fonte de meu estudo, de meu trabalho, pelas quais tenho motivação para acordar para trabalhar.

\section{"Dedico com imensa e sincera gratidão!!"}




\section{AGRADECIMENTOS}

A Deus, por me dar forças, paz e discernimento, que permitiu que tudo se tornasse possível.

A Faculdade de medicina veterinária e zootecnia da universidade de São Paulo (FMVZUSP) e ao Departamento de Reprodução Animal (VRA), pela oportunidade de cursar o doutorado.

Agradeço ao Conselho Nacional de Desenvolvimento Cientifico e Tecnológico (CNPq) pela bolsa de estudos no primeiro ano do doutorado.

Agradeço a Fundação de amparo a pesquisa e ao ensino do estado de São Paulo (FAPESP) pela concessão da bolsa de estudos para a realização do projeto no Brasil (Processo 2010/06827-6) e também pela bolsa de estágio no exterior (Processo 2012/ 2453-0).

Agradeço também a FAPESP pela concessão do auxílio financeiro que permitiu a estruturação e a realização deste projeto (Processo 2010/06821-8).

Ao meu orientador e amigo, professor Ed Hoffmann Madureira, por ter aceitado, permitido e orientado no desenvolvimento deste e de outros trabalhos durante o doutorado, que foram muito importantes para meu desenvolvimento profissional e pessoal, possibilitando assim, a geração dos resultados, que hoje, apresento. Obrigado também pela igualdade que me tratou durante o decorrer do curso, muito de sua conduta pessoal e profissional me ajudaram a enxergar o trabalho e a pesquisa de um modo mais abrangente. Muito obrigado pelos esforços dispensados!!!.

Ao professor Ricardo Carbonari Chebel, por ter dado a oportunidade de realizar parte do meu doutorado no seu laboratório, na Universidade de Minnesota, e por ter me ensinado mais sobre as vacas leiteiras. Obrigado também pela imprescindível ajuda no desenvolvimento da tese, pelas sugestões, pelas conversas técnicas e pelo auxilio nas análises estatísticas. Muito obrigado também por me ajudar a ver a pesquisa e o trabalho de um modo mais dinâmico. 
A Fazenda Colorado, por proporcionar excelente infra-estrutura, conforto e animais de alta qualidade para o desenvolvimento deste estudo. Muito Obrigado!

Ao Senhor Lair Antonio de Souza, proprietário da Fazenda Colorado, por permitir a realização deste estudo, o uso dos animais e da infra-estrutura da fazenda para realizar meu projeto de Doutorado. Muito Obrigado! Parabéns pela fazenda!!

Ao Senhor Antonio Carlos, administrador da Fazenda Colorado. Obrigado por permitir este estudo!

Ao Dr. Sérgio Soriano, médico veterinário responsável da fazenda colorado, por ter aceitado e dado apoio a nossas idéias e também por ter contribuido de forma tão ativa em nosso estudo. Agradeço pelo seu profissionalismo e também pela atenção e dedicação dispensadas, que garantiu que todas as etapas do estudo acontecessem de forma clara e eficiente. Aprendi muito pela convivência, pelas explicações e por seus pontos de vista a respeito do trabalho com as vacas leiteiras. Muito Obrigado!!!!

Ao Senhor Luis, responsável pelo manejo das vacas na fazenda Colorado. Muito obrigado pela dedicação, pelo imprescindível auxilio no desenvolvimento de todas as etapas do estudo, pela colaboração nos protocolos, inseminações. Muito obrigado!!

Aos Funcionários do Manejo na fazenda colorado: Luca, Luisinho, Mauro e Bita; e aos médicos veterinários: Natalia Sobreira e Alex (Sica); e ao Rodrigo Hernandez do gerenciamento de dados. Pela convivência e auxilio Muito Obrigado!

Ao Dr. Neto Oliveira da empresa Nutron, por ceder os dados de dieta e consumo, pelas conversas técnicas e disponibilidade todas as vezes que necessitei. Muito Obrigado!

Aos todos os professores do Departamento de Reprodução Animal, em especial: Dr.Mario Binelli, Dr. Pietro Sampaio Baruselli, Dr. Rubens de Paes Arruda, Dra. Anelise Souza Traldi, Dra. Eneiva Carla Carvalho Celeghini e Dra Claudia Barbosa Fernandes pela convivência, ensinamentos e oportunidade de colaboração em estudos e aulas. Obrigado! 
Agradeço também ao professor Mario Binelli, por todas as vezes que emprestou a centrifuga e as dependências do LFEM para preparamos amostras. Muito obrigado!

A professora Claudia Maria Bertan Membrive, pela amizade desenvolvida durante esses anos, pelos ensinamentos e pelas oportunidades de colaboração em estudos e em aulas. Muito obrigado!

Ao professor Julio Balieiro (FZEA-USP) por todas as vezes que me recebeu em sua sala para tirar dúvidas e pelo auxilio e direcionamento nas análises estatísticas. Muito obrigado!

Ao meu grande amigo Jefferson Rodrigues Gandra e a sua esposa Érika Rosendo Senna Gandra, por nossa grande amizade, pelos bons momentos que compartilhamos desde o mestrado. Mesmo não encontrando com a mesma freqüência, sempre estão presentes e isso é muito importante. Muito obrigado! Que Deus ilumine a cada dia mais suas vidas, carreira profissional e sua filha Julia!

A Bruna Marcelle Martins de Oliveira. Obrigado pela imprescindível colaboração dada neste estudo, pela amizade e pela convivência. É muito ter pessoas como você por perto. Muito Obrigado por tudo! Que Deus continue abençoando imensamente sua vida e sua família!!!

Aos meus grandes amigos Kleber Menegon e Henrique Fullaneti (Rick Sax), pelo companheirismo, pela convivência e também pela amizade que pudemos desenvolver. Que Deus abençoe sempre vocês!! Obrigado!

A Julianne Rezende Naves, que quase não é chata. Obrigado pela amizade, convivência e pela ajuda no desenvolvimento deste experimento. Obrigado!

Ao meu amigo Thiago Santin (Arroiz abeia), obrigado por toda ajuda e empenho no desenvolvimento dos experimentos e pela convivência (apesar de você Abeiar a maioria do tempo). Saiba que sua amizade e sua ajuda foram muito importantes! Obrigado!

A Gabriela Arantes Fonseca, pela ajuda no experimento e nas atividades laboratoriais. Muito obrigado! 
Ao Pedro Ratto e ao professor Flávio Viera Meirelles, pela atenção e ajuda dispensada nos experimentos de aspiração folicular. Muito obrigado!

Ao meu amigo Miguel Henrique de Almeida Santanna, a Marina Nadai Bonin e ao professor José Bento Sterman Ferraz, pelo ultrasson de carcaça e pelo imprescindível auxilio nos experimentos com gado de corte. Obrigado!

Ao meu amigo Rafael Villela Barletta (Bizão), pelos bons momentos convividos desde a graduação e agora na pós-graduação. Muito obrigado e que Deus ilumine seu caminho e do seu filho Miguel!

A Saara Carolina Scolari, pela amizade, pela ajuda no início do experimento e também pelas oportunidades de colaboração em estudos. Muito Obrigado por tudo. Que Deus ilumine seu caminho e o da Mariana!

A Julianne Diniz, pelas oportunidades de colaborações em estudos, e pela convivência. Muito Obrigado!

A Mayara, pela amizade, pela ajuda nas atividades de laboratório, pelos Tererés, pelos empadões e pelas análises laboratoriais. Obrigado!

Ao Julio Barboza, pela amizade, pelas conversas técnicas e colaboração em pesquisas e trabalho. Muito obrigado!

Ao Juan Kamilo Morales, pela amizade e auxilio na rotina de trabalho. Muito obrigado!

Ao meu amigo Manoel Sá Filho, pelas conversas técnicas, pelas explicações de estatística e também pelas oportunidades de colaboração em pesquisas e trabalho. Muito obrigado!

Aos estagiários Virgilio Nunes Barbosa e Thiago Kan Nishimura. Pela ajuda neste e em outros experimentos e pela boa amizade que desenvolvemos. Fico feliz por ver o desenvolvimento profissional de vocês. Muito obrigado! 
A minha amiga Guta (Maria Augusta Alonso), pela amizade desenvolvida durante o doutorado, pelo bom humor, pelo profissionalismo, por sempre ter sanado inúmeras dúvidas acadêmicas!! Obrigado pela ajuda e pelas vezes que me recebeu no haras. Muito obrigado!

Aos estagiários: Fidel, David, Rômulo e Toshiro, pela ajuda durante este experimento, pelas conversas e pizzas depois do trabalho e também pelo Tereré do dia a dia. Muito obrigado!

Aos amigos de doutorado, no VRA: Laís (Kokota), Julia (Maranhão), Robertinha, Milena, Dani, Estelinha, Shirley Flores, Carolina Camargo Rocha, Roberta Harue, João, Andressa, Flávia, Mariana, Samir, Adriano, José Nelio, Julia Baldrigh, Rodrigo Sala; Moana, Leonardo Batissaco, no VNP: Marina Nina, Larissa, Elmeson, Lenita, Alejandro, Fred, Bruno (Chacrete), Rodolfo (Badá), Rui (Libido), Nara, Barbara, Danilo, Rafael; na Esalq: Marcão, Delcy, Alexandre, Ricardo, Fernanda e Monique. Muito obrigado!

Aos pós-graduandos, estagiários do laboratório do professor Ricardo Chebel e aos demais brasileiros em Minneapolis: João Moraes e a Fernanda Shoyama, Paula Regina Basso Silva, karine Machado (a fera), Marília Ferreira, Daniela Neiva Liboreiro, Alice Poggi Brandão, Gabriel Franco e Ana Ruth Dresch, pela convivência, amizade, ensino e ajuda durante minha estadia em Minnesota. Muito obrigado!

Ao Dr Fernando Mesquita e ao Dr Guilherme Pugliesi, pela amizade, auxilio e conversas técnicas. Muito obrigado!

Aos funcionários do Departamento de Reprodução Animal: Sr. José Maria, João, Márcio, Cleiton, Elaine, Sandra e Alexandra, por sempre garantir o funcionamento e desenvolvimento das coisas.

A secretária da pós-graduação Harumi, pelo imprescindível auxílio nas questões acadêmicas e burocráticas, pelo profissionalismo, por sempre ter sanado inúmeras dúvidas. Obrigado!! 
A Dra Letícia Zocorallo, peloi seu bom humor, sinceridade e alegria contagiantes, além de seu empenho profissional. Muito obrigado por Tudo!!!

A Ana Carolina de Mira Geraldo (Qui), pela amizade, pelas festas, pelos trabalhos (desenvolvidos, em desenvolvimento e próximos para desenvolver), pelas conversas, por saber um monte de coisa sobre estresse térmico, pela hospitalidade quando estive em Portugal e pela ajuda profissional em vários momentos. Muito Obrigado Ana Bela de Malhadas!!

A Aline Laila Portes, pela amizade, pela ajuda com as planilhas e pelo empenho que teve durante seu estágio e também por seu jeito Paranaense de ser. Muito obrigado Vermeia!

Aos funcionários do estábulo leiteiro da USP de Pirassununga, Srs: José Antônio Coelho, Antônio Carlos Baladore, Edilson José da Silva, João Paulo Pagotti, José Antônio da Costa, José Antônio da Silva, Luis Tadeu de Oliveira, Carlos Alberto Schimmitt e Valmir Donizetti Botteon. Obrigado pela amizade, esforços e atenção dispensada;

Aos funcionários do setor de gado de Corte: Ismael, Paulinho, Ricardo e Macarrão. Obrigado pela amizade, bom humor esforços e atenção dispensada na organização das estações de monta; Parabéns pelo empenho que têm para garantir a qualidade do trabalho no setor!!

Aos funcionários da Fabrica de Ração da PCAPS, Srs. Cláudio de Jesus Aparecido São Romão, Israel Andrietta, Fernando e José Luiz Aparecido Landgraf, agradeço pela colaboração, e boa vontade.

Aos funcionários do setor de Bubalinocultura, Srs. Cuel e Pavão. Obrigado pela colaboração, amizade e boa vontade no auxilio durante as pesquisas.

Ao professor Dr Eduardo Harry Birgel, a Dra Daniela Birgel e aos pós graduandos Dudu, Flávio, Paulinho e Melina pelas analises hematológicas, pela colaboração, e boa vontade.

Ao Dr. Fernando Schalch, Médico Veterinário da PCAPS, pela convivência durante esses anos, pelos ensinamentos e pela atenção dispensada. 
A Aline Kehrle, a Patrícia Miguez e ao José Rodrigo, pela grande amizade, pelo auxilio em assuntos acadêmicos e pela ótima convivência que tivemos. Época muito boa com vocês!! Muito Obrigado!!

A Dra Lilian Jesus Oliveira, a Aninha Mançanares e ao Rodrigo Barreto, pela amizade, pelo bom humor, pelas análises imunológicas. Muito Obrigado! Torço muito por vocês!!

A professora Dra Maria Claudia Sucupira Araripe (Macau) e suas orientadas (Giovanna Rocha Nunes, Aline Alberti Morgado, Rebeca Alves Weigel, Priscilla Marques Nascimento, Vanessa Martins Storillo, Alessandra Silva Lima) e a técnica Clara Satsuki Mori, pelas análises de estresse oxidativo e pela parceria nos trabalhos durante esses anos. Muito obrigado!!!

Aos amigos da UFU: Cirsu, Japonês, Paraná, Paulinho, Lucão, Guaíra e Piracicaba, pela amizade de longa data, pelo bom humor, pelas conversas fiadas, festas, pelos trabalhos e ajuda profissional. Obrigado!

A o Pastor Carlos Alberto da Cruz e a Pastora Maria Cristina Tramassio da Cruz, pela grande amizade, pelos conselhos e ensinamentos dados em vários momentos que me ajudaram a passar por mais essa etapa de minha vida profissional e pessoal. Obrigado pelas orações e por me ensinar buscar a verdadeira fé em Jesus Cristo!

Aos professores: Dr Roberto Sartori (ESALQ USP) e ao Dr. Milo Wiltbank (University of Wisconsin) pela convivência e ensinamentos. Obrigado!

Ao professor: Dr Luis Felipe Prada e Silva (VNP-FMVZ-USP) e ao professor Heidge Fukumasu (FZEA-USP) pela oportunidade de colaboração em pesquisas. Obrigado!

Ao meu grande amigo, técnico de futebol e de vôlei, Professor Luiz Margutti Netto pela grande e verdadeira amizade, pelo respeito que sempre demonstra com as pessoas e também pela oportunidade de treinar diariamente, mesmo com minha ausência nos treinos agora durante o doutorado. Muito obrigado!! 
Ao grande amigo Wanley Eduardo Lopes do departamento de Cultural, pelas conversas, pela sinceridade, pelas oportunidades oferecidas nas aulas de música, que com certeza, me ajudaram ter um grande crescimento e que sempre me traziam tranqüilidade nessa maratona do dia a dia. Muito obrigado!

Ao Meu Grande amigo Octávio Nobre Roxo, pela amizade, pelas oportunidades, conselhos e ensinamentos profissionais, que me motivaram a dar continuidade na busca por aperfeiçoamento e crescimento profissional. Muito obrigado!!

E finalmente as Vacas, que são as responsáveis pela opção de trabalho e dedicação na minha vida na Medicina Veterinária e na Reprodução Animal, que enchem meus dias de alegria e sentimento de tarefa cumprida, mesmo que com muito cansaço. Cada dia trabalhado me faz ter mais certeza de que faço a única coisa que me faria feliz! 
"Ore como se tudo dependesse de Deus e trabalhe como se tudo dependesse de você".

Porque a sabedoria serve de defesa, como de defesa serve o dinheiro; mas a excelência do conhecimento é que a sabedoria dá vida ao seu possuidor."

Eclesiastes 7:12

"E mesmo que muitas vezes eu dê passos em falso, mesmo que os meus caminhos pareçam errados, mesmo que meu jeito de levar a vida te incomoda, eu sei quem sou, e sei pelo que devo lutar, se você acha que meu orgulho é grande, é porque não conhece o tamanho da minha FÉ!"

\section{Tião Carreiro}




\section{RESUMO}

MATURANA FILHO, M. Efeitos das condições metabólicas de vacas leiteiras durante o período de transição e início de lactação sobre a saúde e fertilidade no inverno e no verão. [Effects of metabolic conditions of dairy cows during transition period and early lactation in winter and summer on health and fertility]. 2013. $152 \mathrm{f}$. Tese (Doutorado em Ciências) - Faculdade de Medicina Veterinária e Zootecnia, Universidade de São Paulo, Pirassununga, 2013.

O presente estudo teve como objetivo verificar as associações entre variáveis plasmáticas ligadas ao metabolismo energético, com outras ligadas ao metabolismo protéico, hepático e renal, em vacas leiteiras durante o período de transição, como também durante o início de lactação no inverno e no verão, de modo que algumas destas variáveis possa ser utilizadas como preditoras da saúde e da fertilidade em vacas leiteiras nos três primeiros serviços. $\mathrm{O}$ experimento foi realizado em uma granja leiteira Comercial (Fazenda Colorado, município de Araras - SP) com 245 vacas leiteiras, multíparas da raça Holandesa. Os animais foram distribuídos, de forma retrospectiva, de acordo com a produção média durante o pico de lactação $(45,9 \mathrm{Kg} /$ leite/ dia). Posteriormente, as vacas foram alocadas dentro dos grupos experimentais (Alta Produção (AP), $\geq 45,9$ até $65 \mathrm{~kg} /$ leite no Pico de lactação; média Produção (MP), entre 30 e 45,8 kg/leite no Pico de lactação). As vacas eram alocadas para o galpão a partir de 35 dias da data de parto prevista, para adaptação prévia de 15 dias antes do período de avaliação e também na eventualidade de algum parto ser antecipado. As dietas foram formuladas de acordo com o NRC (2001). As coletas de amostra de sangue e as avaliações foram realizadas durante o período de transição e durante os protocolos de inseminação artificial em tempo fixo. As variações nos teores de globulinas (GLOB) durante o período de transição foram mais evidentes e significativas nas vacas que desenvolveram metrite, como também nas vacas que não ficaram prenhez após três serviços. Aumentos das concentrações da enzima creatina quinase (CK), foram observados para todos os grupos experimentais durante o pico de lactação. Ainda em relação as variações das enzimas medidas, as vacas do grupo de alta produção de ambos os períodos (API e APV), tiveram valores de Superóxido dismutase (SOD) mais elevados do que as vacas de média produção (MPI e MPV), sendo essas mudanças significativas a para as vacas do grupo AP a partir de 7 dias antes do parto, se mantendo mais elevada até os 104 dias de lactação. Foram observados maiores teores de glicose entre as vacas prenhes no primeiro serviço (menores teores) e aquelas vazias depois da terceira inseminação. As diferenças no perfil lipídico, foram 
observadas tanto no modelo animal de grupo de produção, como também no modelo animal baseado na prenhez para a maioria das variáveis avaliadas, destacando principalmente as mudanças nos teores de AGNE. Para esta variável, houve de grupo de produção $(\mathrm{P}<0,001)$, dia $(\mathrm{P}<0,001)$ e interações entre dia $\mathrm{x}$ estação $(\mathrm{P}<0,001)$ e entre grupo $\mathrm{x}$ dia $\mathrm{x}$ estação do ano $(\mathrm{P}=0,009)$. Nas analises baseadas no modelo de prenhez, houve somente efeito de dias $(\mathrm{P}<0,001)$ para as variações das concentrações de AGNE. As vacas APV tiveram valores mais elevados, bem como um padrão de variação de uréia diferente dos demais grupos até os 100 dias em lactação (DEL). De acordo com o modelo de prenhez, as vacas vazias do período de verão tiveram valores mais elevado de uréia, enquanto que no pico de lactação foram as do inverno. Não foi observada diferença na incidência de doenças entre as vacas de alta ou média produção leiteira, ou entre os períodos $(\mathrm{P}>0,05)$. Houve somente tendência para a incidência de retenção de placenta $(\mathrm{P}=0,09)$ e de metrite $(\mathrm{P}=0,07)$. Houve tendência para a antecipação do parto $(\mathrm{P}=0,1)$, peso da cria $(\mathrm{P}=0,07)$ e metrite no período de verão $(\mathrm{P}=0,08)$. Baseado no modelo de prenhez, foram observadas, diferenças significativas para as variáveis: antecipação do parto $(\mathrm{P}=0,03)$, auxilio parto $(\mathrm{P}=0,05)$, retenção de placenta $(\mathrm{P}=0,009)$, metrite $(\mathrm{P}=0,04)$ e tendências de efeito nas variáveis peso da cria $(\mathrm{P}=0,07)$, deslocamento de abomaso $(\mathrm{P}=0,06)$, cetose $(\mathrm{P}=0,08)$ e endometrite $(\mathrm{P}=0,08)$. Baixas concentrações de glicose (por volta de 45 $\mathrm{mg} / \mathrm{dL})$, aliadas a altas concentrações de AGNE (>0,4 mmol/L) no pré-parto, foram características das vacas que tiveram distocia, retenção de placenta e metrite, além disso, essas vacas tiveram uma pior taxa de prenhez no primeiro serviço. Os teores de AGNE $(0,4$ $\mathrm{mmol} / \mathrm{L})$ e BHBA $(0,7 \mathrm{mmol} / \mathrm{L})$ foram altamente correlacionados com a ocorrência de doenças uterinas. Foi verificado tanto nas vacas com cetose, como nas vacas com deslocamento de abomaso altos teores de AST (por volta de $128 \mathrm{U} / \mathrm{L}$ ), no pré parto. No presente estudo, as variáveis: glicose, AGNE, são importantes preditoras da fertilidade, podendo ser mensuradas no D21 pós parto ou no dia da inseminação artificial $(\mathrm{P}<0,05)$. De acordo com os resultados obtidos, pode se concluir que a produção leiteira não foi um fator de risco para as vacas permanecerem vazias após os três primeiros serviços.

Palavras chave: Afecções puerperais Desempenho reprodutivo. Metabólitos. Periodo de transição. Vacas leiteiras 


\begin{abstract}
MATURANA FILHO, M. Effects of metabolic conditions of dairy cows during transition period and early lactation in winter and summer on health and fertility. [Efeitos das condições metabólicas de vacas leiteiras durante o período de transição e início de lactação sobre a saúde e fertilidade no inverno e no verão]. 2013. 152 f. Tese (Doutorado em Ciências) - Faculdade de Medicina Veterinária e Zootecnia, Universidade de São Paulo, Pirassununga, 2013.
\end{abstract}

The present study aimed to examine the associations between plasma variables related to energy metabolism, with other related to the protein, hepatic and kidney metabolism in dairy cows during the transition period, and during early lactation in winter and summer. So these variables can be used as predictors of health and fertility for dairy cows in the first three services. The experiment was conducted on a dairy farm Commercial (Fazenda Colorado, Araras - SP) with 235 dairy cows, multiparous, Holstein. The animals were divided, retrospectively, according to the average production during peak lactation $(45.9 \mathrm{~kg} / \mathrm{milk} /$ day). Thereafter, the cows allocated within the experimental groups (High Production (AP), $\geq$ 45.9 to $65 \mathrm{~kg} /$ milk at peak lactation; Medium production (MP), between 30 and $45.8 \mathrm{~kg} /$ milk at peak lactation). The cows were allocated to the shed from 35 days from the date of delivery provided, prior to 15 days before the adaptation period of assessment and also in the event of any delivery be anticipated. Diets were formulated according to NRC (2001). Blood samples and evaluations ocurred during the transition period and during the protocols for artificial insemination. Variations in levels of globulins (GLOB) during the transition period were more evident and significant in cows that developed metrits, as well as in cows that were not pregnancy after three services. Increases in concentrations of the enzyme creatine kinase (CK) were observed for all experimental groups during peak lactation. Variations of the enzymes measures, the cows of the group of high production of both periods ( API and APV), had higher levels of superoxide dismutase (SOD) than cows of medium production (MPI and MPV), with these significant changes to the cows in the AP group from 7 days before calving and remained higher until 104 days of lactation. Higher glucose levels between pregnant cows at first service (lower levels) and those empty after the third insemination were observed. The differences in lipid profile were observed in both the animal model of group production, as well as in the animal model based on pregnancy rates for most variables, particularly highlighting the changes in the levels of NEFA. To this variable, there was a production group $(\mathrm{P}<0.001)$, day $(\mathrm{P}<0.001)$ and day $\mathrm{x}$ season interactions $(\mathrm{P}<0.001)$ 
and between group $\mathrm{x}$ day $\mathrm{x}$ season $(\mathrm{P}=0.009$ ). In analyzes based on the model of pregnancy, affected only days $(\mathrm{P}<0.001)$ for changes in NEFA concentrations. The APV cows had higher values, as well as a variation pattern of urea different from the other groups until 100 days in milk (DEL). According to the model of pregnancy, the pregnant cows of the summer had higher values of urea; while at the peak of lactation were the winter. No difference in the incidence of disease among the cows of high or average milk production, or between periods $(\mathrm{P}>0.05)$. There was only trend in the incidence of retained placenta $(\mathrm{P}=0.09)$ and metritis $(P=0.07)$. There was a tendency for earlier calving $(P=0.1)$, calf weight $(P=0.07)$ and metritis in the summer period $(\mathrm{P}=0.08)$. Earlier calving $(\mathrm{P}=0.03)$, dystocia $(\mathrm{P}=0.05)$, retained placenta $(\mathrm{P}=0.009)$, metritis $(\mathrm{P}=0,04)$ : Based on pregnancy model, significant differences were observed for the variables 04$)$ and tendencies in effect creates weight $(\mathrm{P}=$ $0.07)$, displaced abomasum $(\mathrm{P}=0.06)$, ketosis $(\mathrm{P}=0.08)$ and endometrits $(\mathrm{P}=0.08)$ variables. Low glucose concentrations (about $45 \mathrm{mg} / \mathrm{dL}$ ), allied to high NEFA concentrations $(>0.4$ $\mathrm{mmol} / \mathrm{L}$ ) before calving, and were characteristic of cows with dystocia, retained placenta and metritis in addition these cows had a poor pregnancy rate in the first service. The levels of NEFA (0.4 mmol / L) and BHBA (0.7 mmol / L) were highly correlated with the occurrence of uterine diseases. Was observed both in cows with ketosis, as in cows with abomasal displacement high levels of AST (around $128 \mathrm{U} / \mathrm{L}$ ) pre calving. In this study, the variables: glucose, NEFA, are important predictors of fertility, can be measured in D21 postpartum or the day of insemination $(\mathrm{P}<0.05)$. According to the results obtained, concluded that milk production was not a risk factor for cows remain empty after the first three services.

Keywords: Dairy cows. Metabolites. Puerperal disorders. Reproductive performance. Transition period. 


\section{LISTA DE FIGURAS}

Figura 1 - Caracterização dos pontos de coleta e avaliações reprodutivas nos experimentos de inverno e verão.

Figura 2 A-Variação da concentração de proteína total (PT) (mg/dL) no soro de vacas de alta (AP) e média (MP) produção, no inverno (I) e no verão (V).

Figura 2-B -Variação da concentração de proteína total (PT) $(\mathrm{mg} / \mathrm{dL})$ no soro das vacas leiteiras prenhes à primeira IATF ou vazias aos 150 DEL no inverno (I) e no verão (V). 72 Figura 3-A: Variação da concentração de Albumina (ALB) (mg/dL) no soro de vacas de alta (AP) e média (MP) produção, no inverno (I) e no verão (V). 75

Figura 3-B: Variação da concentração de Albumina (ALB) (mg/dL) no soro das vacas leiteiras prenhes à primeira IATF ou vazias aos 150 DEL no inverno (I) e no verão (V). 76 Figura 4-A:Variação da concentração de globulinas (GLOB) (mg/dL) no soro de vacas de alta (AP) e média (MP) produção, no inverno (I) e no verão (V).

Figura 4-B:Variação da concentração de globulinas (GLOB) (mg/dL) no soro das vacas leiteiras prenhes à primeira IATF ou vazias aos 150 DEL no inverno (I) e no verão (V). 77 Figura 5-A:Variação da relação Albumina:globulinas (AGR) no soro de vacas de alta (AP) e média (MP) produção, no inverno (I) e no verão (V).

Figura 5-B:Variação da relação Albumina:globulinas (AGR) no soro das vacas leiteiras prenhes à primeira IATF ou vazias aos 150 DEL no inverno (I) e no verão (V). 78

Figura 6-: Variação da concentração de creatina quinase (CK) (U/L) no soro de vacas de alta (AP) e média (MP) produção, no inverno (I) e no verão (V).

Figura 7-: Variação da concentração de Superóxido dismutase (SOD)/ g de hemoglobina no soro de vacas de alta (AP) e média (MP) produção, no inverno (I) e no verão (V).....84

Figura 8-A: Variação da concentração de glicose (GLI) (mg/dL) no soro de vacas de alta (AP) e média (MP) produção, no inverno (I) e no verão (V).

Figura 8-B: Variação da concentração de glicose (GLI) (mg/dL) no soro das vacas leiteiras prenhes à primeira IATF ou vazias aos 150 DEL no inverno (I) e no verão (V). 87 Figura 9-: Variação da concentração de colesterol total (CT) (mg/dL) no soro de vacas de alta (AP) e média (MP) produção, no inverno (I) e no verão (V). 
Figura 10-: Variação da concentração de triacilglicerol (TG) (mg/dL) no soro de vacas de alta (AP) e média (MP) produção, no inverno (I) e no verão (V).

Figura 11-A: Variação da concentração do colesterol HDL (HDL) (mg/dL) no soro de vacas de alta (AP) e média (MP) produção, no inverno (I) e no verão (V)

Figura 11-B: Variação da concentração do colesterol HDL (HDL) (mg/dL) no soro das vacas leiteiras prenhes à primeira IATF ou vazias aos 150 DEL no inverno (I) e no verão $(\mathrm{V})$

Figura 12-: Variação da concentração do colesterol VLDL (VLDL) (mg/dL) no soro de vacas de alta (AP) e média (MP) produção, no inverno (I) e no verão (V). 92

Figura 13-: Variação da concentração de colesterol LDL (LDL) (mg/dL) no soro de vacas de alta (AP) e média (MP) produção, no inverno (I) e no verão (V).

Figura 14- Variação da relação colesterol:HDL (CTHDL) no soro de vacas de alta (AP) e média (MP) produção, no inverno (I) e no verão (V).

Figura 15-: Variação da relação LDL: HDL (LDLH) no soro de vacas de alta (AP) e média (MP) produção, no inverno (I) e no verão (V).

Figura 16-A: Variação da concentração de ácidos graxos não esterificados (AGNE) (mmol/L) no soro de vacas de alta (AP) e média (MP) produção, no inverno (I) e verão (V).

Figura 16-B: Variação da concentração de ácidos graxos não esterificados (AGNE) (mmol/L) no soro das vacas leiteiras prenhes à primeira IATF ou vazias aos 150 DEL no inverno (I) e no verão (V).

Figura 17-A: Variação da concentração de beta hidroxibutirato (BHBA) (mmol/L) no soro de vacas de alta (AP) e média (MP) produção, no inverno (I) e no verão (V). 98

Figura 17-B: Variação da concentração de beta hidroxibutirato (BHBA) (mmol/L) no soro das vacas prenhes à primeira IATF ou vazias aos 150 DEL no inverno (I) e no verão (V). 98

Figura 18-A: Variação da concentração de uréia (UR) (mg/dL) no soro de vacas de alta (AP) e média (MP) produção, no inverno (I) e no verão (V). 102

Figura 18-B: Variação da concentração de uréia (UR) (mg/dL) no soro das vacas leiteiras prenhes à primeira IATF ou vazias aos 150 DEL no inverno (I) e no verão (V). 102 
Figura 19-A: Variação da concentração de nitrogênio uréico no sangue de vacas de alta (AP) e média (MP) produção, no inverno (I) e no verão (V)

Figura 19-B: Variação da concentração de nitrogênio uréico no sangue de vacas leiteiras prenhes à primeira IATF ou vazias aos 150 DEL no inverno $(\mathrm{I})$ e no verão $(\mathrm{V})$.

Figura 20- Porcentagem de eventos nos quais as variáveis metabólicas medidas no D-21 foram significantes no modelo de regressão logistica.

Figura 21-. Caracterização do protocolo de IATF e dos manejos reprodutivos subseqüentes (ressincronizações).

Figura 22-. Caracterização do protocolo de pré sincronização e de IATF e as variáveis mensuradas

Figura 23-: Taxa de prenhez acumulada aos 150 DEL de acordo com a estação do ano no inverno (I) e no verão (V).

Figura 24-: Taxa de prenhez média durante os três serviços de acordo com a estação do ano no inverno (I) e no verão (V).

Figura 25- Taxa de prenhez acumulada aos 150 DEL de acordo com a produção de leite estação do ano no inverno (I) e no verão (V).

Figura 26-: Taxa de prenhez média durante os 3 primeiros serviços em vaca de alta média acumulada aos 150 DEL de acordo com a produção de leite estação do ano no inverno (I) e no verão $(\mathrm{V})$.

Figura 27- Probabilidade de prenhez no primeiro serviço de acordo com as concentrações plasmáticas de glicose (mg/dL) no D21.

Figura 28- Probabilidade de prenhez no primeiro serviço de acordo com os teores de AGNE (mmol/L) no D21.

Figura 29- Probabilidade de prenhez no primeiro serviço de acordo com as concentrações plasmáticas de glicose $(\mathrm{mg} / \mathrm{dL})$ no momento da IATF.

Figura 30- Probabilidade de prenhez no primeiro serviço de acordo com os teores de AGNE (mmol/L) no momento da IATF. 


\section{LISTA DE QUADROS}

Quadro 1 - Enzimas usadas para monitoramento de vacas durante o período em transição e inicio de lactação 


\section{LISTA DE TABELAS}

Tabela 1 - Composição do TMR durante o período de transição e início de lactação .......62 Tabela 2 - Proporção de ingredientes e composição nutricional do TMR oferecido durante período de transição e início de lactação

Tabela 3 - Parâmetros nutricionais do TMR durante o período de transição e (d -21 \pm 3 a d $21 \pm 3$ ) e no início de lactação (depois do período de transição até d $150 \pm 3$ )

Tabela 4A - Incidência de doenças e fatores ligados ao parto em vacas holandesas de alta produção (AP) e vacas de média produção (MP), no inverno (I) e no verão (V) 111

Tabela 4B - Incidência de doenças e fatores ligados ao parto em vacas holandesas prenhes à primeira IATF ou vazias aos 150 DEL no inverno (I) e no verão (V)

Tabela 5 - Razão de chances da estimativa e intervalo de confiança do perfil máximo de verossimilhança para taxa de auxilio ao parto, em vacas holandesas de alta produção (AP) e de média produção (MP), no inverno (I) e no verão (V), com base em eventos durante o período de transição

Tabela 6 - Razão de chances da estimativa e intervalo de confiança do perfil máximo de verossimilhança para taxa de auxilio ao parto, em vacas holandesas de alta produção (AP) e de média produção (MP), no inverno (I) e no verão (V), com base na mensuração de variáveis bioquímicas no dia -21 em relação ao parto

Tabela 7 - Razão de chances da estimativa e intervalo de confiança do perfil máximo de verossimilhança para incidência de retenção de placenta em vacas holandesas de alta produção (AP) e de média produção (MP), no inverno (I) e no verão $(\mathrm{V})$, com base em eventos durante o período de transição.

Tabela 8 - Razão de chances da estimativa e intervalo de confiança do perfil máximo de verossimilhança para incidência de retenção de placenta em vacas holandesas de alta produção (AP) e de média produção (MP), no inverno (I) e no verão (V), com base na mensuração de variáveis bioquímicas no dia -21 em relação ao parto 118

Tabela 9 - Razão de chances da estimativa e intervalo de confiança do perfil máximo de verossimilhança para incidência de metrite em vacas holandesas de alta produção (AP) e de média produção (MP), no inverno (I) e no verão (V), com base em eventos durante o período de transição 
Tabela 10 - Razão de chances da estimativa e intervalo de confiança do perfil máximo de verossimilhança para incidência de metrite em vacas holandesas de alta produção (AP) e de média produção (MP), no inverno (I) e no verão (V), com base na mensuração de variáveis bioquímicas no dia -21 em relação ao parto

Tabela 11 - Razão de chances da estimativa e intervalo de confiança do perfil máximo de verossimilhança para incidência de cetose em vacas holandesas de alta produção (AP) e de média produção (MP), no inverno (I) e no verão (V), com base na mensuração de variáveis bioquímicas no dia -21 em relação ao parto

Tabela 12 - Razão de chances da estimativa e intervalo de confiança do perfil máximo de verossimilhança para incidência de cetose em vacas holandesas de alta produção (AP) e de média produção (MP), no inverno (I) e no verão (V), com base em eventos durante o período de transição.....

Tabela 13 - Razão de chances do risco de deslocamento de abomaso em vacas holandesas de alta produção (AP) e de média produção (MP), no inverno (I) e no verão (V), com base em eventos durante o período de transição 122

Tabela 14 - Razão de chances do risco de deslocamento de abomaso em vacas holandesas de alta produção (AP) e de média produção (MP), no inverno (I) e no verão (V), com base na mensuração de variáveis bioquímicas no dia -21 em relação ao parto 122

Tabela 15 - Taxa de ciclicidade de vacas holandesas de alta produção (AP) e de média produção (MP), no inverno (I) e no verão (V)

Tabela 16 - Razão de chances da estimativa e intervalo de confiança do perfil máximo de verossimilhança para o risco de prenhez (aos 60 dias) na primeira IATF (75 \pm 3 ) em vacas holandesas de alta produção (AP) e de média produção (MP), no inverno (I) e no verão (V), com base na mensuração de variáveis bioquímicas, hematológicas e de produção no dia 21 pós parto 132

Tabela 17- Razão de chances da estimativa e intervalo de confiança do perfil máximo de verossimilhança para o risco de prenhez (aos 60 dias) na primeira IATF (75 \pm 3 ) em vacas holandesas de alta produção (AP) e de média produção (MP), no inverno (I) e no verão (V), com base na mensuração de variáveis bioquímicas e de produção no dia da IATF 133 


\section{SUMÁRIO}

1 INTRODUÇÃO ......................................................................................................................................29

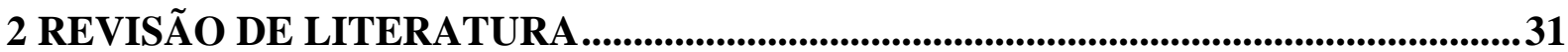

2.1 Biologia das vacas leiteiras durante o Período de Transição e Início do período de Lactação .31

2.2 Avaliação metabólica durante o período de transição como ferramenta para maximizar a saúde e o desempenho reprodutivo de vacas leiteiras ....................................................36

2.3 Balanço energético negativo e atividade ovariana.................................................................44

2.5 Período de Transição e estresse oxidativo .....................................................................................48

2.6 Efeitos do estresse calorico, sobre a saúde, o desempenho produtivo e reprodutivo de vacas leiteiras . .54

3 Capítulo 1: diferenças metabólicas durante o período de transição DE vacas de alta e média produção no inverno e no verão..............................................................................................59

3.1 Justificativa e hipótese .................................................................................................................59

3.2 Objetivos ..............................................................................................................................................59

3.3 Objetivos Específicos..............................................................................................................................59

3.4 Materiais e Métodos ........................................................................................................................60

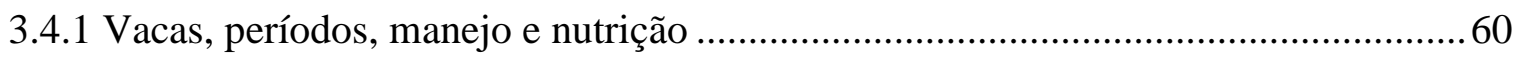

3.4.2 Coletas de sangue, avaliação da saúde, análises metabólicas ..................................65

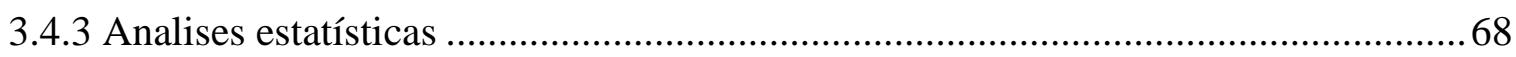

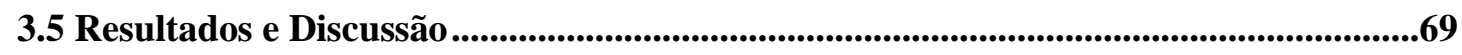

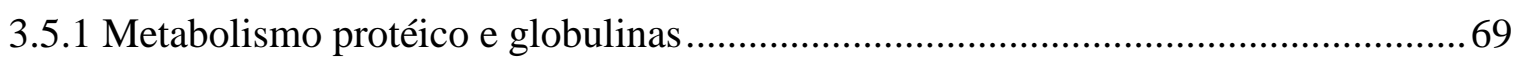

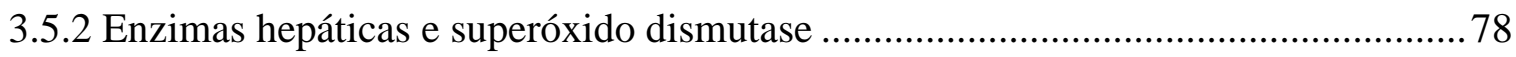

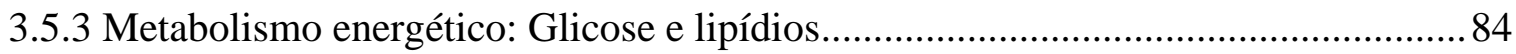

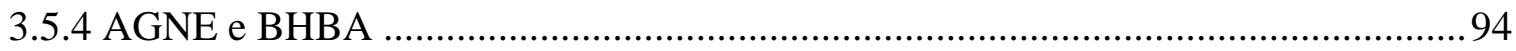

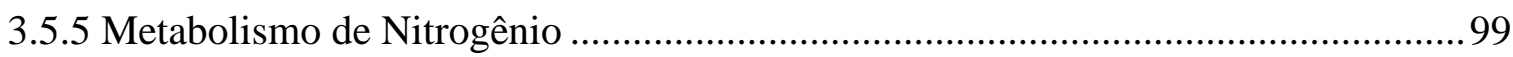

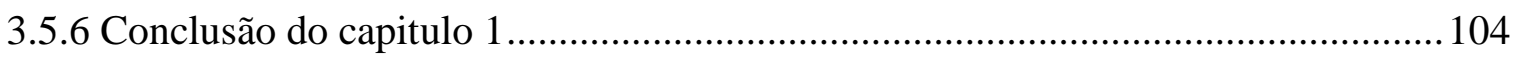


4 Capítulo 2: Avaliação e escolha de variáveis preditoras da incidência de DOENÇAS NO período de transição e início de lactação em vacas de alta e média produção no

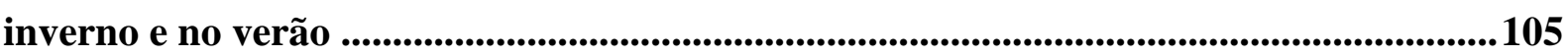

4.1 Justificativa e Hipótese ....................................................................................................................105

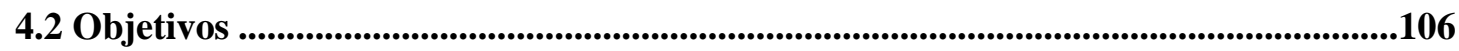

4.3 Objetivos Específicos..........................................................................................................................106

4.4 Materiais e Métodos ....................................................................................................................106

4.4.1 Produção e composição do leite .......................................................................... 107

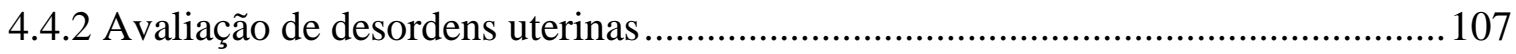

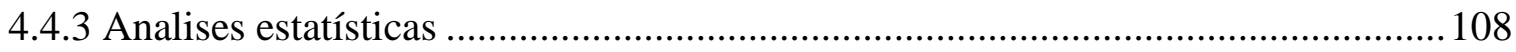

4.5 Resultados .................................................................................................................................109

4.5.1 Incidência e fatores predisponentes na ocorrência de doenças puerperais ............. 109

4.5.2 Fatores preditores da taxa de auxilio ao parto e retenção de placenta .................... 117

4.5.3 Fatores preditores da ocorrência metrite e endometrite ........................................ 119

4.5.4 Fatores preditores da ocorrência cetose e de deslocamento de abomaso ................120

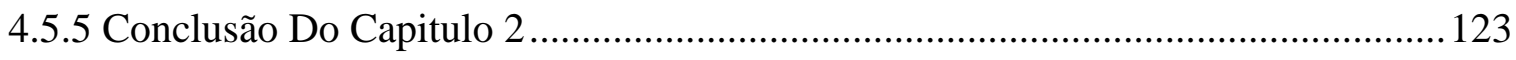

5 Capítulo 3: Desempenho reprodutivo e principais variáveis preditoras da fertilidade nos três primeiros serviços no inverno e no verão....................................................................... 124

5.1 Justificativa e Hipótese .......................................................................................................................124

5.2 Objetivos .................................................................................................................................125

5.3 Objetivos Específicos...............................................................................................125

5.4 Materiais e Métodos .............................................................................................................125

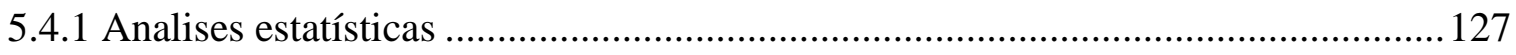

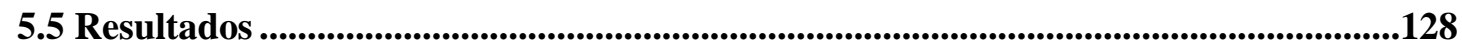

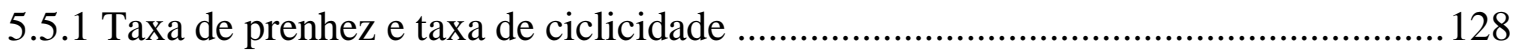

5.5.2 Fatores metabólicos ligados a taxa de prenhez na primeira inseminação............... 131

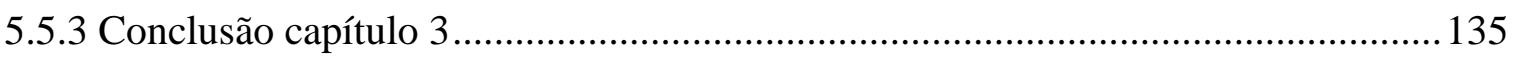

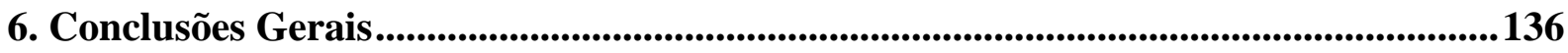

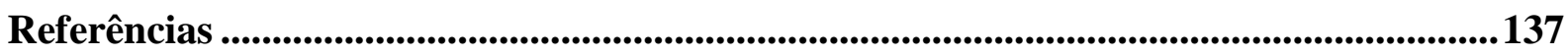




\section{INTRODUÇÃO}

O período de transição está compreendido entre as últimas três semanas pré-parto até as três primeiras semanas de lactação (GRUMMER, 1995). É uma fase do ciclo produtivo das vacas leiteiras, caracterizada por inúmeras alterações metabólicas e hormonais, visando o estabelecimento da produção leiteira (DRACKLEY, 1999).

A maioria dos problemas de saúde, dentro do ciclo produtivo de uma vaca leiteira, ocorre durante este período, quando comparado com outras fases de lactação. A regulação e coordenação principalmente do metabolismo de lipídios no fígado, intestino e glândula mamária são os principais componentes das adaptações da lactação. Acúmulo de lipídios no fígado pode contribuir com o aumento dos problemas de saúde e diminuição da produção de leite (DRACKLEY, 1999).

As alterações metabólicas, hormonais, imunológicas e de estresse oxidativo ocorridas durante o período de transição nas vacas leiteiras, refletem diretamente na saúde, na produção e na fertilidade dos rebanhos (KIMURA et al., 2002; HATAMOTO, 2004; AGARWAL et al., 2012).

Durante o período de transição e no inicio do período de lactação, as vacas leiteiras passam por períodos de balanço energético negativo (BEN), caracterizado pelo aumento da mobilização de reservas energéticas, normalmente do tecido adiposo, para atender às demandas voltadas à produção de leite (GRUMMER, 1995). Uma das consequências do BEN é o comprometimento da qualidade dos oócitos, devido a exposição aos altos teores dos ácidos graxos não esterificados (AGNE), que afeta a estabilidade e a integridade da membrana dos oócitos, com isso, pode prejudicar a taxa de fertilização e comprometer o desempenho reprodutivo dos rebanhos (LEROY et al, 2005a b; VAN HOECK et al., 2012; 2013).

Tem sido demonstrado em alguns estudos nos últimos anos, um aumento dos problemas reprodutivos nos rebanhos leiteiros (LUCY et al., 2001; LUCY et al., 2000). As principais causas relacionadas a isso são: 1) O aumento substancial na produção de sólidos no leite para atender as exigências do mercado consumidor. Portanto, essa intensa seleção genética tem gerado aumentos substanciais nos requerimentos de energia, proteína e minerais; 2) Falhas de manejo nutricional e de condições de conforto e ambiência, que conseqüentemente, aumenta a susceptibilidade a doenças e ao estresse calórico; 3) Ineficiência nos sistemas de manejo reprodutivo e de monitoramento da saúde dos rebanhos (LUCY, 2000; NRC, 2001; 
LEBLANC et al., 2005; MATURANA FILHO, 2009; FREITAS JR et al., 2010; GANDRA, 2012).

Algumas práticas de manejo, como o monitoramento da condição metabólica e nutricional pré parto podem auxiliar no estabelecimento de estratégias de manejo, que minimizem a ocorrência de doenças e o descarte involuntário, consequentemente, aumentando a rentabilidade do sistema produtivo.

Durante o período de transição ocorre também um aumento na formação de radicais livres em função da mobilização de reservas corporais. No entanto, durante este período, a síntese de compostos antioxidantes normalmente é insuficiente devido ao baixo consumo de matéria seca (CMS) e consequentemente de minerais como zinco, cobre e manganês. Quando ocorre esse aumento da produção de radicais livres em detrimento a produção de antioxidantes, é chamado de estresse oxidativo, que afeta a saúde, principalmente por interferir na condição imunológica das vacas (LACETERA et al., 2005).

Portanto, este trabalho tem como intuito escolher variáveis metabólicas para monitorar a saúde e a fertilidade de rebanhos leiteiros no Brasil, bem como auxiliar na elaboração de modelos de experimentação animal para pesquisas de contexto multidisciplinar. 


\section{REVISÃO DE LITERATURA}

Ao longo da revisão de literatura serão abordados temas referentes ao assunto pesquisado, com o intuito de prover informações para justificar e discutir os materiais e métodos e resultados do presente trabalho.

\subsection{Biologia das vacas leiteiras durante o Período de Transição e Início do período de Lactação}

O período de transição compreende as últimas três semanas de gestação, o parto e as três primeiras semanas de lactação (GRUMMER, 1995). O início de lactação é caracterizado como sendo os primeiros 90 a 120 dias de lactação após o parto. Durante esses períodos, ocorrem inúmeras mudanças na demanda de nutrientes no organismo da vaca leiteira, sendo necessárias coordenadas alterações no metabolismo, para atender suas exigências de mantença, lactação e reprodução. (BELL, 1995; TAMMINGA et al., 1997; HERDT, 2000).

No final do período seco, quando a vaca se aproxima do parto, ocorre grande aumento do crescimento fetal, ocasionando elevação da pressão interna nos órgãos digestivos e diminuição do seu espaço físico, além disso, ocorre grande variação hormonal, marcado principalmente pelo aumento nas concentrações sanguíneas de estrógenos e corticóides. Como conseqüência, ocorre redução no consumo de matéria seca em até 30\%, (NRC, 2001; MATURANA FILHO, 2009).

Em função da assincronia entre a demanda metabólica e o consumo de alimentos no final da gestação e no início do período pós parto, as vacas leiteiras passam por um período de balanço negativo de nutrientes $(\mathrm{BEN})$, principalmente, energia, proteína e cálcio (BELL, 1995). Para atender a esse estado de balanço negativo de nutrientes, ocorrem inúmeras adaptações fisiológicas no organismo da vaca. Essas alterações endócrinas e fisiológicas durante o BEN, tornam as vacas mais vulneráveis a problemas de saúde, como doenças infecciosas e metabólicas no pós-parto imediato (GRUMMER, 1993; HERDT et al., 2000; GRUMMER, 2004). Aproximadamente $75 \%$ das doenças em vacas leiteiras acontecem no primeiro mês pós-parto (LEBLANC et al., 2006), o que afetará diretamente a produtividade e a rentabilidade dos rebanhos leiteiros (GRUMMER, 1993). 
As adaptações envolvem mobilização da energia armazenada nos tecidos corporais, alterações na utilização de substratos, e na conversão dos combustíveis corporais (HERDT, 2000). Além disso, a capacidade de estocar nutrientes é relativamente pequena para vacas leiteiras, portanto, altas quantidades de reservas corporais são mobilizadas até que o consumo de matéria seca (CMS) seja regulado (COPPOCK; WILKS, 1991). Durante este período, ocorre um aumento substancial do catabolismo do tecido adiposo, e elevação das concentrações plasmáticas de ácidos graxos não-esterificados (AGNE) em duas ou três vezes, em um curto prazo de semanas (CONTRERAS et al., 2011).

Os AGNE presentes na corrente sanguínea podem ser utilizados por diversos tecidos corporais para a geração de energia e economia na utilização de glicose (PULLEN et al., 1989). Por isso, as concentrações plasmáticas destes, refletem a magnitude da mobilização do tecido adiposo e normalmente estes compostos são incorporados na gordura do leite. No parênquima hepático, a maior parte dos AGNE são oxidados completa ou parcialmente, esterificados ou exportados como lipoproteína de muito baixa densidade (VLDL) (GRUMMER, 1993). O fígado aparentemente metaboliza os AGNE de acordo com a proporção de seu suprimento via corrente sanguínea, (EMERY et al., 1992; GRUMMER, 1993; DRACKLEY, 1999; HERDT, 2000; BUTLER, 2004; HOEDEMAKER et al., 2004).

No entanto, a capacidade hepática de oxidação de ácidos graxos e exportação de VLDL é relativamente baixa em ruminantes (GRUMMER, 1993). Assim, o excesso de AGNE no fígado, durante o período de transição e início da lactação, podem ser: 1) completamente oxidados a dióxido de carbono para fornecimento de energia para o fígado, 2) parcialmente oxidados para produção de corpos cetônicos que são liberados no sangue e servem com fontes de energia para outros tecidos ou 3) reconvertidos para triacilglicerol (TG) (BERTICS et al., 1992; GRUM et al., 1994, NRC, 2001).

O acúmulo de triacilglicerol no parênquima hepático reduz a capacidade do fígado em detoxicar amônia em uréia (STRANG et al., 1998), resultando na diminuição da capacidade de gliconeogênese hepática. Com isso, ocorre uma diminuição da síntese a partir do propionato, que é o principal precursor de glicose em ruminantes (CADORNIGA-VALINO et al., 1997; OVERTON et al., 1999). Dessa forma, o animal estará sujeito a alterações nos desempenho produtivo e reprodutivo, bem como alterações de saúde, sendo, portanto, prioridade a identificação de estratégias de manejo que promovam alterações no metabolismo hepático, principalmente de lipídeos, que resultem na diminuição da ocorrência de fígado gorduroso em vacas leiteiras durante o período de transição (MASHEK et al., 2005). 
O BEN que normalmente se inicia nos últimos dias pré-parto e se estende até o inicio da lactação, além de provocar acúmulo de triglicérides no parênquima hepático, também compromete outras funções importantes, como a síntese de glicose e IGF-1, por aumentar a resistência à insulina. Tanto o acúmulo de triglicérides no fígado como de cetonas no sangue estão ligados ao atraso da primeira ovulação pós-parto (OVERTON, 2004; BUTLER, 2004).

Portanto, o manejo nutricional e a alimentação são fatores essenciais para maximizar o potencial de cada vaca durante o ciclo produtivo, entretanto, devem atender a inúmeros critérios que estão relacionados a esses eventos que afetam as mudanças na fisiológicas nas últimas semanas de gestação (NRC 2001).

Assim sendo, as vacas no período seco devem ser agrupadas em grupos distintos: o primeiro grupo abrange os animais que iniciam o período de repouso, que vai da primeira a sexta semana dentro do período seco, denominada Fase 1 ou "Far Off"; o segundo grupo abrange os animais desde da Fase 1 até as três últimas semanas que antecedem o parto, sendo denominada Fase 2 ou “Close Up” (NRC 2001).

Aumentando a densidade energética na dieta de 1,30 para 1,62 mega-calorias de energia líquida de lactação (Mcal ELL) /kg de matéria seca (MS) e a proteína bruta de 12 para 16 por cento durante os vinte e seis dias pré-parto pode resultar em maior ingestão de energia durante o periparto e diminuição de até 9 vezes o acúmulo de gordura no parênquima hepático $(15,0$ mg/grama de tecido) (VANDEHAAR et al., 1999).

A disponibilidade de energia regula a secreção de insulina, que é capaz de inibir ou minimizar a lipólise e o aumento de AGNE na circulação. Esse é um dos pontos que ajuda a melhorar o consumo de matéria seca (CMS) no pré-parto e no pós-parto imediato (DOEPEL et al., 2002). Além disso, estes autores citam que este quadro influencia positivamente a função hepática e a fertilidade.

A redução da capacidade da insulina em inibir a síntese hepática de glicose representa uma das adaptações promovidas pelo hormônio do crescimento no inicio da lactação, permitindo que mais glicose seja utilizada para a síntese de leite (BAUMAN, 1992; BAUMAN; CURRIE, 1980; BAUMAN; GRIINARI, 2003). Segundo Overton et al. (1999) a demanda estimada de glicose de uma vaca da raça holandesa é de 1000 a 1100 g/d durante os últimos dias de gestação, mas aumenta rapidamente após o parto para aproximadamente 2500 g/d aos 21 dias pós-parto.

Tais adaptações também têm implicações sobre o ambiente folicular, visto que aumentar o aporte de glicose para os ovários, pode estimular a síntese de aromatases e desmolases nos folículose e consequentemente favorecer a esteroidogênese. Ou seja, de particular 
importância, um maior estoque folicular dessas enzimas pode contribuir com a diminuição de condições anovulatórias (WILTBANK, 2004).

Ainda sobre o metabolismo animal, o hormônio do crescimento (GH) é o principal regulador metabólico no inicio da lactação, pois altera os sinais homeostáticos em vários tecidos e orgãos, com isso, há um direcionamento preferencial de nutrientes para a produção leiteira, chamado homeorrese. Além dessas mudanças, os efeitos do GH, envolve ações mediadas por fatores de crescimento semelhantes à insulina (IGF), os quais são produzidos principalmente no fígado (BAUMAN, 1992).

Devido a essas mudanças, no inicio do período pós parto, ocorre uma diminuição da oxidação tissular da glicose para aumentar a disponibilidade da mesma para o úbere, durante a lactação (LUCY, 2000). Isso ocorre porque o GH aumenta o transporte de aminoácidos através da membrana celular, proporcionando melhores condições para a síntese protéica e aumento do catabolismo das gorduras (LEHNINGHER, 2006).

De uma forma geral, existem três vias metabólicas principais para a glicose, que são alteradas devido às ações do GH:

a) armazenamento (como polissacarídeo): pois, o GH é fundamental na estimulação de enzimas glicogênicas (KNAPP et al., 1992), bem como altera inúmeros mecanismos celulares nos hepatócitos, onde, é o principal local de estoque de glicogênio para as vacas leiteiras. No início do período pós-parto, as concentrações de GH no sangue das vacas leiteiras, estão aumentadas, mas as concentrações de glicose normalmente estão baixas, devido ao direcionamento desta para a síntese de lactose pela a glândula mamária (HAYIRLI, 2006; LEROY et al., 2008a; LUCY et al., 1992). Portanto, altas concentrações de GH no pós-parto induzem a um estado de insulinorresistente (LUCY, 2001), que é uma condição imprescindível para ativação de enzimas lipolíticas (LEROY et al., 2008a). A baixa capacidade hepática dos ruminantes em reesterificar ácidos graxos livres, juntamente a diminuição da atividade antilipolítica da adenosina e estimulo da atividade lipolítica das catecolaminas, gera um aumento da deposição de triacilgliceróis no fígado, e diminui o armazenamento de glicogênio (HOUSEKNECHT; BAUMAN, 1997; LANNA; BAUMAN, 1999).

b) Oxidação pela via das pentoses-fosfato: aumentando a síntese de ácidos nucléicos, e de NADPH. Este processo é o caminho central no catabolismo da glicose no fígado e é de grande importância para regulação homeostática do controle das concentrações sanguíneas deste metabólito nas vacas leiteiras durante o inicio de lactação (BAUMAN, 1992; GRUMMER, 2005; CAMMACK, 2006; LEHNINGHER, 2006; GONZÁLES, 2008). 
c) A regulação da produção de acetil-CoA que é feita pelo produto, ou seja, ATP, NADH e mesmo ácidos graxos de cadeia longa, que inibem o complexo PDH. Sendo que ao contrário, AMP, CoA e $\mathrm{NAD}^{+}$ativam este complexo. De modo que maiores concentrações destes compostos, normalmente estão ligadas a um menor fluxo e também produção de acetilCoA. De um modo geral, a reação de oxidação do piruvato é ativada em situações de maior exigência energética, como, por exemplo, a alta produção leiteira, encaminhando mais acetilCoA para o Ciclo de Krebs (LEHNINGHER, 2006).

Vários estudos têm demonstrado que os teores plasmáticos de glicose no início da lactação, em vacas sadias, estão por volta de 65,4 ×5,3 mg/dL (GONZÁLES et al., 1996; MATURANA FILHO, 2009; CERRI et al., 2009), podendo haver variações de até 12,5\% destes valores.

Dessa forma, semelhante à glicose, a insulina tem papel importante no metabolismo energético celular por estimular o transporte da glicose para dentro das células por proteínas (GLUT) (LAWRENCE; MCKERN; WARD, 2007). Além disso, a insulina apresenta efeitos anti cetogênicos que podem interferir positivamente na eficiência reprodutiva durante o BEN, reduz a produção de AGNE pelo fígado, estimula a lipogênese, inibe a lipólise, aumenta a utilização de corpos cetônicos em tecidos periféricos e diminui tanto a disponibilidade de substrato como a atividade de enzimas hepáticas responsáveis pela cetogênese (BROCKMAN; LAARVELD, 1986).

Existe forte relação entre o balanço energético no pós-parto e a retomada da atividade ovariana, que também tem alta correlação com as necessidades nutricionais e metabólicas voltadas a produção leiteira. São esperadas diferenças significativas no balanço energético das vacas antes do parto e no início de lactação, uma vez que estão bem estabelecidas as diferenças existentes entre as exigências nutricionais para mantença na vaca gestante em terço final de lactação em comparação a alta energia exigida para mantença e produção de leite na vaca em inicio de lactação (MCNAMARA et al., 2003). Portanto, as estratégias de manejo nutricional nesta fase devem priorizar a manutenção de consumo adequado de energia e do escore de condição corporal (ECC), visando minimizar a severidade do balanço energético, sendo este aspecto de grande importância para o entendimento da influencia da nutrição na reprodução. 


\subsection{Avaliação metabólica durante o período de transição como ferramenta para maximizar a saúde e o desempenho reprodutivo de vacas leiteiras}

A situação metabólica dos animais e transtornos no funcionamento de órgãos, bem como a adaptação do organismo diante de desafios nutricionais, fisiológicos e desequilíbrios metabólicos, podem ser monitorados por variáveis bioquímicas, hematológicas e hormonais Estas ferramentas, aliadas com o exame clínico, apresentam grande utilidade no diagnóstico de casos clínicos não bem evidenciados, mas que podem ocasionar prejuízos no desempenho produtivo e reprodutivo dos rebanhos leiteiros (GONZÁLES, 1997; GONZÁLES et al., 2000).

Segundo, Gonzáles (1997), a interpretação do perfil bioquímico é complexa tanto quando aplicada a rebanhos quanto a indivíduos, devido aos mecanismos que controlam a concentração sanguínea de vários metabólitos e também, à grande variação desses valores em função de fatores como raça, idade, estresse, dieta, nível de produção leiteira, manejo, clima e estado fisiológico, principalmente na lactação e a gestação.

Segundo Leblanc (2006), existe duas razões principais para monitorar vacas leiteiras durante o período de transição e realizar testes metabólicos em particular:

- Rebanho ou grupo: para monitorar o manejo nutricional com metas para detecção de problemas ou mudanças no programa de manejo;

- Individual: identificar e intervir nas vacas com alto risco para doenças metabólicas e reprodutivas.

No início da lactação, vacas de alta produção apresentam balanço energético negativo, e sua duração afeta o desenvolvimento de ondas foliculares, o intervalo para a primeira ovulação e a taxa de concepção ao $1^{\circ}$ serviço (STAPLES et al., 2000). O anestro pós-parto pode reduzir a eficiência reprodutiva por atrasar o primeiro serviço, pois as vacas que não apresentam estro nos primeiros 30 dias pós-parto requerem mais serviços por concepção com maior risco de serem descartadas (THATCHER; WILCOX, 1973; COTE, 1991; COZZI et al., 2011).

Durante o período de BEN, as vacas mobilizam grande estoque de reservas corporais, que pode ser medido pela avaliação do escore de condição corporal (ECC). Essas mudanças na condição corporal estão correlacionadas com o desempenho produtivo e reprodutivo dos rebanhos (EDMONSON et al., 1989; BUTLER et al., 1996; GRUMMER, 2004; MATURANA FILHO, 2009, D’ÂNGELO, 2009). 
Vacas leiteiras que apresentam escore de condição corporal inferior à 2,5 (escala de 15), no início do período pós-parto, em $80 \%$ dos casos, apresentam redução da atividade ovariana durante o período voluntário de espera, aumentando, em média, 11 dias o período até o primeiro serviço. Em torno de $38 \%$ das vacas, com escore entre 2,5 e 2,75, podem apresentar-se anovulatórias à ultra-sonografia, enquanto que, as vacas com escore 3,25 a 3,5 podem apresentar por volta de 20\% de casos de anovulação (BRITT, 1992; WILTBANK, 2004).

Em geral, os folículos dessas vacas têm tamanho superior ao observado no estado préovulatório (17 mm a $20 \mathrm{~mm}$ ), sendo também freqüente o aparecimento de cistos foliculares (>22 mm). Entretanto, muitas vacas anovulatórias nos rebanhos leiteiros não apresentam condições de escore abaixo de 2,5 (WILTBANK, 2004).

Em situações onde as concentrações de glicose, insulina e progesterona, são baixas, associadas com o teor elevado de AGNE e Beta Hidroxi Butirato (BHB), os pulsos de LH são negativamente influenciados, principalmente no início da lactação (BUTLER, 2004).

Devido a todas essas alterações, a mensuração dos teores plasmáticos de colesterol em vacas leiteiras é uma importante ferramenta, para indicar alterações hepáticas e nutricionais. Os teores plasmáticos de colesterol correspondem a 30\% do total de lipídeos no plasma (GONZÁLES; ROCHA, 1998).

Os teores de colesterol em vacas leiteiras sadias, durante o período de transição e início de lactação variam entre 106 e 152 mg/dL (GONZÁLEZ et al., 1996; MATURANA FILHO, 2009), enquanto que os teores de HDL devem ser por volta de 47 à 90 mg/dL, o de LDL por volta de 112 à 180 mg/ dL e de VLDL por volta de 6 à 11 mg/dL (CERRI et al., 2009; MATURANA FILHO, 2009).

Dokovic et al. (2005) mostraram que nas vacas com altos teores plasmáticos de corpos cetônicos, a concentração sérica de triacilgliceróis (TG) é menor que em vacas sadias, pois os mesmos são acumulados no tecido hepático. González et al. (2009) relatam que 52\% de vacas com alta lipomobilização no primeiro mês de lactação e $43 \%$ de vacas com baixa lipomobilização no terceiro mês de lactação, tiveram valores de TG <10,6 mg/dL. Os autores não acharam correlação significativa entre valores sanguíneos de TG e AGL nem entre TG e BHB, sugerindo que valores isolados de TG não podem ser considerados como indicadores de lipomobilização. Contudo, todas as vacas com Cetose subclínica e $61 \%$ de vacas com alta lipomobilização (AGL> $400 \mu \mathrm{mol} / \mathrm{L}$ ) tiveram valores de TG menores de 8,8 mg/dL. Esses resultados merecem ver com mais atenção o significado dos TG em vacas no início da lactação. Um aumento na quantidade de AGNE plasmático acima de $15 \mathrm{mg} / \mathrm{dL}$ configuram 
um quadro clínico de cetose (DUFFIELD et al., 2009; DUFFIELD et al., 2005ab; GONZÁLES, 2009), principalmente quando coincidem com teores plasmáticos de glicose < $45 \mathrm{mg} / \mathrm{dL}$ e triacilglicerol (TAG) $<10,6 \mathrm{mg} / \mathrm{dL}$ (LEBLANC et al., 2005). De fato, o catabolismo dos ácidos graxos é uma das fontes de energia mais importantes para muitos organismos, estando responsável, por exemplo, por cerca de $70 \%$ das necessidades energéticas voltadas para lactação, coração e fígado das vacas leiteiras (BAUMAN, 1992).

Durante o processo de $\beta$-oxidação, os ácidos graxos sofrem sucessivamente a remoção de pares de carbonos sob a forma de acetil-CoA, com início no terminal carboxil da cadeia. As moléculas de acetil-CoA provenientes da $\beta$-oxidação serão oxidadas a $\mathrm{CO}_{2}$, juntando-se as moléculas derivadas da glicose, via glicólise e da oxidação do piruvato, entrando no ciclo do ácido cítrico. Estes dois processos ocorrem na mitocôndria e reduzem os transportadores de elétrons $\mathrm{NADH}$ e $\mathrm{FADH}_{2}$, com isso, pode aumentar a produção de radicais livres em detrimento a capacidade de produzir enzimas oxidantes e caracterizar uma condição de estresse oxidativo (LEHNINGHER, 2006).

Essas alterações no metabolismo hepático que levam a um aumento do processo de cetogênese e contribuem com um aumento da infiltração de lipídeos nos hepatócitos, devido a capacidade reduzida dos ruminantes transformar os ácidos graxos livre em VDL, essa situação, mantém as concentrações plasmáticas de AGNE e BHB mais elevadas (KLEPPE et al., 1988; PULLEN et al., 1989). Entretanto, a capacidade do tecido hepático em esterificar AGNE em TG paerece ser aumentada com a aproximação do parto (SKAAR et al., 1989; VASQUEZ-ANON et al., 1994; GRUM et al. 1996; VAN DEN TOP et al., 1996; RUKKWAMSUK et al., 1999; LITHERLAND et al., 2003). Se a absorção de AGNE pelo fígado é excessiva, poderá predispor a ocorrência do fígado gorduroso (BOBE et al., 2004).

$\mathrm{O}$ balanço energético negativo e a insuficiência de carboidratos no fígado após o parto pode resultar em quadros clínicos ou subclinícos de cetose, bem como a desordens no parto (HERDT, 2000; HERDT, 2000; DRACKLEY et al., 2001; JORRITSMA et al., 2003; BOBE et al., 2004; DUFFIELD et al., 2005a; DUFFIELD et al., 2009).

Existem associações fortes entre as concentrações de AGNE e BHB com a saúde e com o desempenho de vacas leiteiras durante o período de transição (LEBLANC, 2006). Vacas com teores plasmáticos maiores que $0,4 \mathrm{mmol} / \mathrm{L}$, em torno de 2 semanas antes do parto, tem de 2 a 4 vezes o aumento do risco deslocamento de abomaso para esquerda (CAMERON et al., 1998; LEBLANC et al., 2005), 1,8 vezes aumentado o risco de retenção de placenta (RP) (LEBLANC et al., 2004); 2 vezes mais chance de ser descartada antes de 60 dias em lactação (DEL) e 1,5 vezes o aumento do risco de ser descartada durante o restante da lactação 
(DUFFIELD et al., 2005b), além disso, estima-se uma perda média de 1,2 kg/dia de leite nos primeiros 120 dias de lactação(CARSON, 2008).

Vacas com altas concentrações de AGNE no período pré parto podem desenvolver casos de Cetose (BHB > 1200-1400 $\mu \mathrm{mol} / \mathrm{l})$ no início da lactação, o que leva a um aumento de 4 a 8 vezes no risco de deslocamento de abomaso (GEISHAUSER et al. 2000; LEBLANC et al., 2005; DUFFIELD et al., 2009), decréscimo na produção leiteira (DUFFIELD, 2000), aumento da Duração e severidade dos casos de mastite (SURIYASATHAPORN, 2000) e diminuição de 3 a 4 vezes a probabilidade de prenhez na primeira IATF (WALSH et al., 2004).

Em um estudo de campo desenvolvido por Duffield et al. (2000) com 1010 vacas em 25 rebanhos, o pico de incidência de novos casos de cetose subclínica foi de $30 \%$ na primeira semana após o parto, com a ocorrência de novos casos por volta da terceira semana pós-parto. A incidência acumulada até a nona semana pós-parto foi de $43 \%$ A incidência média variou de 8 a $80 \%$ entre os rebanhos avaliados. No mesmo estudo o pico de prevalência foi de $33 \%$ e ocorreu na segunda semana pós-parto. Os autores sugeriram este ponto como ótimo para testar a ocorrência de Cetose subclínica, o que corrobora com o estudo de Oetzel (2004).

De acordo com Oetzel (2004), o teste de cetose subclínica deve ser realizado em todas as vacas entre o $5^{\circ}$ e o $50^{\circ} \mathrm{DEL}$, sugerindo que combinando este teste com uma investigação compreensiva e práticas de manejo nutricional podem diminuir esses problemas, o que corrobora com o estudo de Maturana Filho et al., (2010), onde vacas receberam um dieta rica em ácidos graxos de cadeia longa, para compensar o déficit energético durante essa fase do ciclo produtivo.

Entretanto, no estudo de Maturana Filho et al. (2010), onde os animais foram distribuídos em três grupos experimentais, em delineamento inteiramente casualizado, recebendo a mesma ração durante o períodos pré e pós-parto: 1) Controle (C); 2) Óleo de soja (OS); e 3) Sais de cálcio de ácidos graxos insaturados de cadeia longa (SC) não foram encontradas alterações das concentrações de glicose $(65,9 \mathrm{mg} / \mathrm{dl} \mathrm{C} ; 61,5 \mathrm{mg} / \mathrm{dl} \mathrm{OS} ; 64,1$ $\mathrm{mg} / \mathrm{dl} \mathrm{SC})$, AGNE (0,73 mmol/l C; $0,83 \mathrm{mmol} / \mathrm{l} \mathrm{OS} ; 0,73 \mathrm{mmol} / \mathrm{l} \mathrm{SC})$ e BHB $(0,68 \mathrm{mmol} / \mathrm{l} \mathrm{C}$; 0,56 mmol/l OS; 0,76 mmol/l SC), entre os grupos experimentais, mas houve efeito de tempo (semanas em relação ao parto) para as concentrações de AGNE e BHBA, nos períodos pré e pós- parto. Semelhantemente, Duske et al. (2009) avaliaram a suplementação de sais de cálcio de ácidos graxos em vacas da raça Holandesa com média de produção de leite de 35,0 kg/vaca /dia, e utilizaram dietas controle com $(2,7 \% \mathrm{EE})$ e com gordura $(5,5 \% \mathrm{EE})$ com base na 
matéria seca total. Estes autores observaram valores de AGNE e BHB superiores ao estudo de Maturana Filho (2009), sendo de 0,85 mmol/1 e 1,10 mmol/l, respectivamente.

Oetzel (2004) e Leblanc et al. (2005) recomendam incluir todas as vacas entre 5 e 50 dias em lactação no teste de Cetose subclínica e na investigação de rebanho inclua o numero de animais doentes, os descartes devido a doença e as práticas nutricionais da propriedade, pois, a Cetose do tipo 1 (baixa glicose sangüínea, entretanto, sem infiltração lipídica hepática) ou a Cetose do tipo 2 (associada com fígado gorduroso desde o parto) ocorre entre 5 e 15 dias pós-parto. Quando a cetose é detectada nas duas primeiras semanas pós-parto e que entraram no pré-parto com condição corporal abaixo de 3 ou acima de 3.75, ocorre um aumento da reincidência ou de novos casos no lote até 6 semanas pós-parto, que é também consequiência do manejo nutricional durante o período de transição (DUFFIELD, 2000).

Publicações indicam que a prevalência típica de cetose subclínica é cerca de $15 \%$ (OETZEL, 2004) a 20\% (DUFFIELD et al., 1998; DUFFIELD et al., 2003).

O deslocamento de abomaso (DA) é um problema comum e economicamente importante no ciclo de produção das vacas leiteiras. Os custos de tratamento, além da baixa produção leiteira aumentam o risco da vaca ser descartada. Existem numerosos fatores de risco para o DA (SHAVER, 1997; CAMERON et al., 1998), mas é importante identificar os principais fatores para melhor compreender a patogênese da doença.

Geishauser et al. (2000) demonstraram uma associação entre vários metabólitos no período de transição com o risco de subseqüente DA. A cetose subclínica e a baixa atividade da enzima aspartato aminotransferase no sangue, nas duas primeiras semanas pós parto foram associadas com o aumento no risco de DA.

Além dos AGNE, outros metabólitos são importantes no monitoramento de vacas durante período de transição e inicio de lactação.

As principais proteínas plasmáticas são a albumina, as globulinas e o fibrinogênio. Elas estão envolvidas em múltiplas funções, tais como a manutenção da pressão osmótica e da viscosidade do sangue, o transporte de nutrientes, metabólitos, hormônios e produtos de excreção, a regulação do $\mathrm{pH}$ sanguíneo e a participação na coagulação sanguínea (CUNINGHAN, 2006; CAMMACK 2006; GONZALES, 2009). As proteínas sanguíneas são sintetizadas principalmente pelo fígado, sendo que a taxa de síntese está diretamente relacionada com o estado nutricional do animal, especialmente com os níveis de proteína e de vitamina A, e com a funcionalidade hepática. A hipoproteinemia pode ser indicadora de estados de subnutrição, bem como de insuficiência ou de lesão hepática e hemorragias. Animais jovens têm valores menores que os animais adultos (PAYNE et al., 1970). 
Hiperproteinemia pode ser observada em casos de desidratação e infecções. Foram relatados valores de proteína total sérica em vacas da raça holandesa no sul do Brasil de 84,5 $\pm 18,8 \mathrm{~g} / \mathrm{L}$ (GONZÁLES et al., 1996) e de 77,6 \pm 12,96 g/L em vacas durante o período de transição (MATURANA FILHO, 2009).

A albumina é a proteína mais abundante no plasma, perfazendo cerca de $50 \%$ do total de proteínas. É sintetizada no fígado e contribui em $80 \%$ da osmolaridade do plasma sanguíneo, constituindo também um transportador de ácidos graxos livres, aminoácidos, metais, cálcio, hormônios e bilirrubina. A albumina também tem função importante na regulação do pH sanguíneo, atuando como ânion (CUNINGHAM, 2006). Para a detecção de mudanças significativas na concentração de albumina sérica é necessário um período de pelo menos um mês, devido à baixa velocidade de síntese e de degradação (GONZÁLEZ et al., 2000).

Quando as concentrações de albumina e de uréia estão diminuídas, pode indicar deficiência protéica na alimentação. Níveis de albumina diminuídos com níveis de uréia normais ou elevados, acompanhados ou não de valores de enzimas altos, podem ser indicadores de falha e/ou de lesão hepática (GONZALES et al., 1997). Existe uma relação direta entre a capacidade de aumento da albuminemia das vacas leiteiras no pós-parto com o desempenho reprodutivo e produtivo (GONZALES; ROCHA, 1998).

A hipoalbuminemia pode afetar o metabolismo e as concentrações obtidas de outras substâncias devido ao papel da albumina como transportador, principalmente de cálcio, fructosamina e ácidos graxos livres, além de causar queda da pressão osmótica do plasma com probabilidade de levar a ascite, o que ocorre quando a concentração de albumina cai para menos de 20 g/L (GONZALES; ROCHA, 1998).

Os teores plasmáticos adequados para vacas em torno de 70 dias de lactação estão por volta de 49,3 \pm 10,5 g/L (GONZÁLEZ et al., 1996) e por volta de 32,7 $7.6 \mathrm{~g} / \mathrm{L}$ durante o período de transição (MATURANA FILHO, 2009).

A concentração sérica de globulinas pode ser obtida pela diferença de concentração entre as proteínas totais e a albumina. As globulinas podem ser divididas em três tipos, $\alpha, \beta$ e $\gamma$, identificadas mediante eletroforese. Elas têm funções no transporte de metais, lipídeos e bilirrubina, bem como papel na imunidade (fração gama). As globulinas são indicadores limitados do metabolismo protéico, tendo mais importância como indicadores de processos inflamatórios (GONZALES et al., 1997; CUNINGHAM, 2006). Altos concentrações plasmáticas de globulinas estão associados a doenças infecciosas. Um aumento nas globulinas 
devido a estados infecciosos inibe a síntese de albumina no fígado como mecanismo compensatório para manter constante o nível protéico total e, portanto, a pressão osmótica sanguínea. Por outra parte, na disfunção hepática, o nível de albumina cai e o de globulinas aumenta (GONZALES et al., 1997; CAMMACK, 2006).

A concentração de globulinas diminui ao final da gestação devido à passagem de gamaglobulinas para o colostro (ROSSATO et al., 2001). Em rebanhos do sul do Brasil os valores médios de globulina foram de 49,3 \pm 10,5 g/L (GONZÁLEZ et al., 1996).

Os níveis de uréia e nitrogênio uréico no plasma e no leite podem indicar intensa mobilização energética, adaptações ao estresse e também são afetados pela nutrição, sendo um indicador sensível, direto e imediato da ingestão de proteína (MULLIGAN et al., 2006). Altos teores plasmáticos de N-uréico estão associados a efeitos deletérios na fertilidade e na qualidade do leite (WITTWER et al., 2000).

Os valores médios de uréia sanguínea variaram entre 25 e 57 mg/dL (GONZÁLEZ; ROCHA, 1998; MATURANA FILHO, 2009), mostrando uma ampla variação, em função do manejo nutricional, do estágio de lactação, do estado metabólico e da produção leiteira (GONZÁLEZ et al., 2001; MATURANA FILHO, 2009).

Os teores plasmáticos de uréia, em conjunto com os teores de albumina e de creatinina, podem ser usados para determinar o balanço protéico da dieta (GONZÁLEZ et al., 1996).

Altas concentrações plasmáticas nitrogênio uréico (NUS) estão associadas com diminuição da fertilidade em vacas leiteiras (BUTLER, 2000), por alterar os teores de uréia, $\mathrm{Mg}, \mathrm{K}, \mathrm{P}$ e $\mathrm{Zn}$ e o $\mathrm{pH}$ uterino. As maiores mudanças no ambiente uterino ocorrem durante o a período inicial do desenvolvimento embrionário e aumenta até $15 \%$ a porcentagem de oócitos não fertilizados para vacas com teores acima de $57 \mathrm{mg} / \mathrm{dl}$ de NUS (BUTLER, 2000). Teores acima de $14,9 \mathrm{mg} / \mathrm{dL}$ de nitrogênio uréico no leite (NUL), também podem ser usados como ferramenta de manejo para monitorar a condição nutricional das vacas. Altos teores NUL, acima de 14,9 mg/dL, têm sido associado à efeitos negativos na reprodução e no balanço energético de vacas leiteiras no início da lactação (BUTLER et al., 1996).

A De acordo com Gonzales et al. (1996) e Hoedemaker et al. (2004) a medição da atividade enzimática no plasma de vacas no início de lactação é de grande importância pois, representam alterações na síntese, função e morte dos tecidos (HARPER, 2003). Além disso, como a concentração intracelular das enzimas é bem maior que no plasma, danos celulares relativamente pequenos podem levar a aumentos significativos da atividade das enzimas no plasma. Desse modo é possível fazer inferência sobre o lugar e o grau do dano celular, uma vez que muitas enzimas são específicas de órgãos (LEHNINGHER, 2006). 
Quadro 1 - Enzimas usadas para monitoramento de vacas durante o período em transição e inicio de lactação

\begin{tabular}{|c|c|c|c|}
\hline Enzima & Órgão & Interpretação do aumento & Referencia \\
\hline $\begin{array}{c}\text { Aspartato } \\
\text { aminotransferase } \\
\text { (AST) }\end{array}$ & $\begin{array}{c}\text { Fígado, músculo e } \\
\text { eritócitos }\end{array}$ & $\begin{array}{c}\text { Lesão muscular (deficiência } \\
\text { de vitamina E e selênio) e } \\
\text { lesão hepato celular }\end{array}$ & Gonzáles (2007) \\
\hline $\begin{array}{c}\text { Creatina quinase } \\
\text { (CK) }\end{array}$ & Músculo & $\begin{array}{c}\text { Lesão muscular } \\
\text { (rabdomiólise), infiltração } \\
\text { hepática e miopatias }\end{array}$ & $\begin{array}{c}\text { Hoedemaker et al. } \\
\text { (2004) }\end{array}$ \\
\hline $\begin{array}{c}\text { Gama-glutamil } \\
\text { transferase } \\
\text { (GGT) }\end{array}$ & Fígado, rins & $\begin{array}{c}\text { Dano hepático (hepatite, } \\
\text { obstrução biliar e } \\
\text { aflatoxicoses) }\end{array}$ & Souza et al. (2005) \\
\hline
\end{tabular}

As aminotransferases são um grupo de enzimas, que por transferência de grupos amino, catalisam a interconversão de aminoácidos e $\alpha$-oxoacidos. A AST (aspartato aminotransferase ou transaminase glutamato oxaloacetato) foi encontrada no citoplasma e mitocôndria das células estudadas. Em casos de pequenas lesões dos tecidos hepáticos, a forma predominante de soro AST é a do citoplasma, com uma menor quantidade originária da mitocôndria. Em lesões graves dos tecidos verifica-se uma maior liberação mitocondrial da enzima. Elevados níveis de AST podem indicar enfarte de miocárdio, hepatopatia, distrofia muscular e lesões orgânicas. Embora a maior atividade da enzima se verifique no músculo do coração, detectouse também uma atividade significativa no cérebro, fígado, mucosa gástrica, tecido adiposo e rins (CUNINGHAM, 2006). Os padrões normais dessa enzima é 34,7 $\pm 10,6$ UI para vacas holandesas.

A creatinina quinase é derivada, praticamente em sua totalidade, do catabolismo da creatina presente no tecido muscular. A conversão de creatina em creatinina é uma irreversível, dependente de fatores estequiométricos (GONZALES, 2000; LEHNINGHER, 2006; CAMMACK, 2006; CUNINGHAM, 2006). A excreção de creatinina só se realiza por via renal, uma vez que ela não é reabsorvida nem reaproveitada pelo organismo, sendo os níveis plasmáticos de CK altamente correlacionados (LEHNINGHER, 2006). Os níveis de creatinina podem ser interpretados de forma similar aos de uréia no tocante à taxa de filtração renal (GONZALES, 2000). Em bovinos, o valor máximo de creatinina plasmática é de 130 U/l (WITTWER et al., 2000), sendo necessário determinar os valores deste metabólito para as vacas leiteiras durante o período de transição. 


\subsection{Balanço energético negativo e atividade ovariana}

O BEN se inicia no pré-parto e se estende durante o inicio da lactação pode comprometer funções importantes, como a síntese de glicose e IGF-1, e aumenta a resistência à insulina, que juntas reduzem a capacidade de resposta dos ovários e gonadotrofinas. Tanto o acúmulo de triglicérides no fígado como de cetonas no sangue estão ligados ao atraso da primeira ovulação pós-parto (OVERTON, 2004; BUTLER, 2004).

Na primeira semana pós parto, após a redução das concentrações de estradiol, ocorre um pico de FSH (GINTHER et al., 1996), conseqüentemente, a primeira onda folicular entre 4 e 12 dias pós-parto (SAVIO et al., 1990a; GINTHER et al., 1996; HAUGHIAN et al., 2002). Apesar de haver o crescimento folicular, normalmente a primeira ovulação em vacas de alta produção, ocorre somente por volta dos 33 dias de lactação (FERGUSON, 1996). A primeira ovulação pós-parto geralmente ocorre na ausência na manifestação de estro (LOPEZ et al., 2004).

O balanço energético negativo interfere primariamente com a habilidade do eixo hipotalâmico-hipofisário em desenvolver um padrão de hormônio luteinizante (LH) necessário para estimular o desenvolvimento folicular e a ovulação. Secundariamente, o déficit de energia e a baixa concentração de insulina durante este período podem limitar a responsividade dos ovários a estimulação pelas gonadotrofinas (BUTLER, 2004). A magnitude do balanço energético negativo influencia o desenvolvimento folicular, o intervalo entre o parto e a primeira ovulação e a taxa de concepção ao $1^{\circ}$ serviço, além disso, as vacas que não apresentam estro nos primeiros 30 dias pós-parto requerem mais serviços por concepção (THATCHER; WILCOX, 1973; STAPLES et al., 1998; MOALLEM et al., 2007).

Vacas com baixa condição corporal (escala 1-5) apresentam maior probabilidade de não ovularem, principalmente vacas com condições de escore inferior a 2,5, estas normalmente apresentam baixa atividade ovariana ou são anovulatórias, apresentando folículos pequenos a ultra-sonografia. Entretanto, grande quantidade de vacas anovulatórias também é encontrada entre aquelas com bons escores de condição corporal, superior a 2,75, mais de $20 \%$ das vacas com escore 3,25 também pode ser anovulatórias (ADAMS, 1992; BRITT, 1992). Em geral, os folículos dessas vacas têm tamanho superior ao observado no estado pré-ovulatório $(17 \mathrm{~mm}$ a $20 \mathrm{~mm}$ ), sendo também freqüente o aparecimento de cistos foliculares (>22 mm). Apesar de ser provável que vacas com escore de baixa condição corporal (ECC) não consigam ovular, a 
maioria das vacas anovulatórias nos rebanhos leiteiros não apresentam escores baixos (WILTBANK et al., 2002).

Vacas de alta produção (acima de $40 \mathrm{~kg} / \mathrm{dia}$ ) estão mais susceptíveis a condições mais severas ou mais prolongadas de BEN. Essas vacas apresentam uma redução de até 6,7 horas na expressão do estro (WILTBANK et al., 2002).

Vacas de baixa ( $\leq 20 \mathrm{~kg}$ /dia) e média produções $(28$ a $30 \mathrm{~kg} /$ dia $)$ têm baixa taxa de ovulação dupla, ao contrário das vacas de alta produção (acima de $40 \mathrm{~kg} /$ dia), que podem chegar à 50\% e ocasionar até 20\% de partos gemelares (GINTHER, 1989).

A prevalência de anestro durante o período voluntário de espera (65 a 80 dias de lactação), não pode ultrapassar 20 a $30 \%$, podendo ser verificado pelas concentrações plasmáticas de progesterona e pela ultra-sonografia (WILTBANK et al., 2002).

A probabilidade de desenvolver uma condição anovulatória no inicio do período pós parto, é semelhante para vacas tanto de alta como de baixa produção. Pois o fator principal ligado a esses casos de anovulação é o escore de condição corporal. Em média, 83\% das vacas magras $(<2,5$ ECC) estão anovulatórias durante os primeiros 70 dias pós parto, nas vacas com escore entre 2,5 e 2,75 o percentual de anovulação é por volta de $38 \%$. Em vacas com escore corporal entre 3,0 e 3,25 a anovulação pode chegar a 21,8 \% e em vacas com ECC acima de 3,25 no máximo 8\% são anovulatórias (GINTHER, 1996; WILTBANK et al., 2002; GUMMEN; WILTBANK, 2003). Foi proposto por Wiltbank (2004), que a porcentagem do rebanho que não está ciclando entre os dias 65 a 75 de lactação, não pode ultrapassar 20 a $30 \%$ que pode ser verificado pelas concentrações plasmáticas de progesterona ou por ultrassonografia.

Spicer et al. (1990) demonstraram que o balanço de energia entre os dias vinte e sessenta pós-parto foi inversamente relacionado ao número de dias do parto até a primeira ovulação. Resultados semelhantes foram obtidos por Beam e Butler (1997), que encontraram correlação positiva entre o número de dias do parto até a primeira ovulação com tempo para o restabelecimento do balanço energético, observando também uma melhoria no desenvolvimento de folículos maiores (> $15 \mathrm{~mm}$ ) (SPICER et al., 1990; LARSON, 1992; BEAM; BUTLER, 1997; BUTLER, 2001; MATURANA FILHO, 2009). Além disso, a primeira ovulação normalmente ocorre entre 12 a 15 dias após o ponto mais negativo do balanço de energia e também a baixa concentração de insulina durante este período pode limitar a responsividade dos ovários a estimulação pelas gonadotrofinas (BEAM; BUTLER, 1997, 1998). 
Em relação ao desempenho reprodutivo, conforme citaram Gwazdauskas et al. (2000), no mínimo $80 \%$ das vacas leiteiras apresentam balanço energético negativo durante o início da lactação, variando em intensidade e duração. Durante o balanço energético negativo, eventos homeorréticos sustentam as necessidades metabólicas da lactação e, aparentemente, a função da glândula mamária tem prioridade metabólica em relação à função ovariana (STAPLES et al., 1998). Assim, a função reprodutiva no pós-parto é diretamente dependente da disponibilidade de nutrientes a serem utilizados para a lactação.

Em geral, os folículos dessas vacas têm tamanho superior ao observado no estado préovulatório (17 mm a $20 \mathrm{~mm}$ ), sendo também freqüente o aparecimento de cistos foliculares (>22 mm). Entretanto, muitas vacas anovulatórias nos rebanhos leiteiros não apresentam condições de escore abaixo de 2,5 (WILTBANK et al., 2002).

Dessa forma, a duração e a magnitude do balanço energético negativo pós-parto podem ser importantes reguladores no restabelecimento do ciclo estral e subseqüente manutenção da gestação (MATURANA FILHO, 2009). O balanço energético negativo interfere, primariamente, com a habilidade do eixo hipotalâmico-hipofisário em desenvolver um padrão de hormônio luteinizante (LH) necessário para estimular o desenvolvimento folicular e a ovulação. Secundariamente, o déficit de energia e a baixa concentração de insulina durante este período podem limitar a responsividade dos ovários à estimulação pelas gonadotrofinas.

O intervalo para a primeira ovulação no período pós-parto depende da recuperação da função normal do eixo hipotalâmico-hipofisário-gonadal (BUTLER; SMITH, 1989). A composição bioquímica e hormonal do plasma reflete a situação metabólica dos animais, transtornos no funcionamento de órgãos, adaptação do organismo do animal diante de desafios nutricionais, fisiológicos e desequilíbrios metabólicos (CERRI et al., 2009). Esta ferramenta, aliada com o exame clínico, apresenta grande utilidade no diagnóstico de casos clínicos não bem evidenciados, que podem ocasionar prejuízos no desempenho produtivo e reprodutivo dos rebanhos leiteiros (GONZÁLES, 1997; GONZÁLES et al., 2000). 


\subsection{Balanço energético negativo e qualidade dos oócitos}

Nas últimas décadas, os grandes aumentos na capacidade de produção das vacas leiteiras têm afetado a taxa de concepção (TC) em grandes rebanhos (LUCY, 2001). A Taxa de concepção nos rebanhos leiteiros é de 35\% à $40 \%$ em vacas multíparas, $51 \%$ em primíparas e maior que $65 \%$ em novilhas, mostrando que os atuais sistemas de produção têm afetado negativamente a fertilidade e a eficiência reprodutiva das vacas em lactação (BUTLER et al., 2004).

Com relação à fertilidade na inseminação artificial, há uma relação positiva entre a taxa de concepção e início precoce dos ciclos ovulatórios pós-parto (MATURANA FILHO, 2009). A taxa de concepção aumenta com o decorrer dos ciclos, sendo provável que haja uma relação com a melhora do perfil de progesterona (LUCY, 2001).

Os teores de progesterona aumentam nos três primeiros ciclos ovulatórios no pós-parto, entretanto, há uma menor evolução, no aumento dos teores nas vacas de alta produção, que normalmente apresentam condições mais severas e/ou mais prolongadas de BEN (BUTLER et al., 1996).

$\mathrm{Na}$ medida em que aumentarem as demandas metabólicas para síntese de leite, as funções reprodutivas podem ser diminuídas, quando uma ingestão compensatória de nutrientes não é conseguida (SANTOS, 2005). Este quadro é, freqüentemente, acompanhado por uma diminuição da glicose, insulina e IGF-I, aliada a um aumento de AGNE e BHB. Isso afeta a viabilidade dos oócitos e a taxa de fertilização (BRITT, 1992; WEBB et al., 2008).

Vacas que passam por períodos prolongados de BEN têm uma diminuição de até 2 vezes a probabilidade de ficarem prenhes à primeira inseminação (BRITT, 1992; WEBB et al., 2003; WALSH et al., 2007).

O BEN é capaz de prejudicar a competência de desenvolvimento dos oócitos aos oitenta a cento e vinte dias de lactação, que normalmente é compatível com o período de primeiro e segundo serviço nas fazendas leiteiras e dá indícios da toxicidade das altas concentrações de AGNE sobre o desenvolvimento inicial do embrião, principalmente nas vacas que perdem mais que uma condição corporal no inicio de lactação (KRUIP et al., 19981).

Britt (1992) sugeriu que a menor taxa de concepção em vacas de leite de alta produção, é explicada por efeitos deletérios do balanço energético negativo no início da lactação, na qualidade dos folículos, influenciando a taxa de concepção pela menor qualidade dos oócitos e quantidade de progesterona secretada pelo corpo lúteo. Quando os folículos são expostos à 
condições adversas (balanço energético negativo, estresse térmico, doenças metabólicas) durante o seu desenvolvimento (a foliculogênese dura aproximadamente 60 dias), os efeitos adversos sobre a qualidade dos oócitos ocorreriam 40 a 60 dias seguintes, quando estariam ovulando, gerando quedas aos índices reprodutivos, devido ao atraso da primeira ovulação, falhas na concepção, tanto pelas concentrações inadequadas de progesterona , como pelo efeito negativo causado no oócito liberado após a ovulação. Estratégias de alimentação, saúde e nutrição das vacas em lactação, voltadas ao melhor desempenho reprodutivo devem começar no período de transição (BUTLER, 2008).

Uma forma interessante de avaliar a qualidade do oócito é por ativação partenogenética (PORCIUNCULA, 2009). Este método, evita possíveis oscilações, que podem acontecer durante a fusão do espermatozóide com o óvulo e também a subjetividade, que ocorrem com alguns métodos visuais (DE BEM, 2009).

No verão é mais comum que as vacas leiteiras apresentem um quadro mais severo de BEN, que muitas vezes ocasiona um aumento dos teores plasmáticos de AGNE, acima de 0,8 mmol/ L, por períodos mais prolongados. De acordo com Leblanc et al., (2005), essas vacas têm de 2 a 4 vezes mais chances de desenvolverem o deslocamento de abomaso e 1,8 vezes mais chances de ter retenção de placenta (LEBLANC, 2006; DUFFIELD et al., 2009). Além disso, vacas leiteiras que desenvolvem esses problemas metabólicos ou reprodutivos, podem reduzir significativamente seu consumo de matéria seca em até $70 \%$, o que agrava mais o estado de saúde do animal. Isso aumenta até 2 vezes mais a chance dessa vaca ser descartada antes dos 60 dias de lactação e até 1,5 vezes de ser descartada até o final da lactação (DUFFIELD et al., 2009).

\subsection{Período de Transição e estresse oxidativo}

Embora seja um mecanismo de proteção, a produção de radicais livres, causa inúmeras alterações funcionais no organismo da vaca leiteira, que aumenta de 2 a 4 vezes a susceptibilidade a doenças e compromete o desempenho reprodutivo, principalmente por afetar a qualidade do oócito e a sobrevivência do embrião (VAN HOECK et al., 2013).

A resposta do organismo ao estresse oxidativo é o aumento na produção e liberação de hormônios, como o cortisol, de enzimas como a creatina fosfoquinase (CK), de 
neurotransmissores e eicosanóides. Por conseguinte, pode afetar, negativamente, as funções imunológicas e reprodutivas (LEWIS; MCKAY, 2009).

Muitos estudos têm demonstrado uma diminuição da eficiência produtiva e reprodutiva de vacas leiteiras (HAFEZ, 2004; WILTBANK, 2004). Nos períodos de maior demanda metabólica, há um aumento de marcadores de estresse oxidativo, que ocasionam modificações progressivas dos mecanismos fisiológicos normais, para permitir que o indivíduo responda ao agente estressor. No verão, o estresse oxidativo pode ser mais severo e causar danos maiores ao DNA e às membranas dos oócitos e dos espermatozoides (BRITT, 1992; NICHI, 2003).

A produção de energia nas células gera radicais livres e outras espécies reativas de oxigênio de forma contínua e abundante. O oxigênio é usado na queima de moléculas de glicose que atuam como combustível biológico. Nesta operação liberam energia que ocorre na cadeia de transporte de elétrons da mitocôndria. Um terço do oxigênio consumido pode escapar do sistema e resultar na formação de radicais livres. Radicais livres são espécies reativas de oxigênio, que apresentam eletrons desemparelhados. Os radicais livres possuem elétrons de valência desemparelhados, e, portanto, são altamente reativos, podendo inclusive reagir entre si em uma dimerização para formar uma molécula com todos os elétrons emparelhados (LEHNINGHER, 2006). Muitas enzimas, como as xantinas oxidases e aminoácidos oxidases levam a formação de peróxidos de hidrogênio. Superóxido, peróxidos de hidrogênio e radicais hidroxil, são mais reativos que o oxigênio e são chamados de espécies reativas de oxigênio (Eros) (CAMMACK, 2006).

O radical hidroxil causa danos a proteínas, ácidos nucléicos e ácidos graxos de membrana lipídica (peroxidação lipídica). É produzido como resultado da radiação ionizante e representa maior atividade mutagênica, sendo também produzido a partir de $\mathrm{H} 2 \mathrm{O} 2$ na reação de Fenton (LEHNINGHER, 2006; CAMMACK, 2006; SORDILLO et al., 2009).

$\mathrm{H} 2 \mathrm{O} 2+\mathrm{Fe} 2+($ ou $\mathrm{Cu}+)->\mathrm{Fe} 3+($ ou $\mathrm{Cu} 2+)+\mathrm{OH}$ radical + OHSuperóxido

O Superóxido, só combina com o óxido nítrico, que é um outro agente sinalizador desse tipo de reação. O produto formado, o peróxidonitrito (OONO), também é considerado um Eros e também causa a nitração do grupo tirosil hidroxila das proteínas, causando danos na membrana protéica (CAMMACK, 2006).

A produção em larga escala das espécies reativas de oxigênio durante períodos de maior exigência metabólica nas vacas leiteiras, como no período de transição, tem um potencial considerável para causar danos nos tecidos onde são produzidos, causando o estresse oxidativo, que pode afetar a homeostase, a condição imunológica e conseqüentemente o desempenho animal. Durante esses processos metabólicos, na proliferação celular e na defesa 
contra agentes agressores, também são produzidos radicais livres. Entre estes, pequenas quantidades de espécies reativas de oxigênio (ERO) são constantemente produzidas. A quantidade ideal destes metabólitos é mantida pelo sistema de defesa antioxidante, que evita danos celulares. O dano celular ocorre quando há aumento na produção de ERO e/ou diminuição das defesas antioxidantes (HATAMOTO, 2004). Entretanto, existe grande necessidade de estudos que mostrem quais os teores plasmáticos aceitáveis desses marcadores para vacas leiteiras, sem que a saúde e a eficiência reprodutiva sejam afetadas.

O conceito de estresse oxidativo baseia-se na relação entre os níveis celulares de oxidantes e antioxidantes. Um desequilíbrio nesta relação pode determinar alterações importantes na fisiologia celular considerando-se por um lado o papel de radicais livres em vias de sinalização e por outro como agentes do dano oxidativo. Segundo Helmut Sies (1991), estresse oxidativo define-se como uma perturbação no balanço pró-oxidante-antioxidante com predomínio de pró-oxidantes, levando a potenciais danos.

Neste sentido, o estresse oxidativo poderia resultar, como apontado por Halliwell e Gutteridge (2007): da redução dos níveis de antioxidantes: por mutações que afetam a atividade de defesas antioxidantes enzimáticas (superóxido dismutases, catalases, glutationa peroxidases, glutationa redutases, peroxirredoxinas, tiorredoxinas, enzimas de reparo); por ação de toxinas que depletem defesas antioxidantes (como a depleção de glutationa (GSH) por conjugação a metabólitos e xenobióticos em sua biotransformação); por deficiências dietárias de certos minerais (cofatores de enzimas antioxidantes) e antioxidantes; -e/ou do aumento na produção de espécies reativas: por exposição de células e tecidos a altas tensões de O2 (condições de hiperóxia); por efeito de substâncias (fármacos, xenobióticos, toxinas) que possam gerar espécies reativas em sua biotransformação; ou por ativação excessiva de sistemas naturais de produção de espécies reativas (como na ativação de fagócitos em doenças inflamatórias crônicas).

Alterações na fisiologia celular associadas ao estado de estresse oxidativo podem decorrer não apenas diretamente do dano oxidativo a biomoléculas (afetando sua função), mas também da interferência dos mesmos nas vias de sinalização (via oxidação e redução de grupos sulfidrila (-SH) presentes em proteínas (FORMAN et al., 2004), além de íons Fe, presentes por exemplo nos grupos [Fe-S] de certas enzimas (LILLIG et al., 2005). As consequências do estresse oxidativo são variadas, estando associadas ao tipo celular e extensão dos danos oxidativos (reversíveis ou irreversíveis), podendo ainda afetar a comunicação intercelular e inibir a progressão do ciclo celular, favorecendo a liberação de fatores pró-apoptóticos (MIKALSEN et al., 1994; CHANDRA et al., 2000). 
Os componentes antioxidantes, tais como, a glutationa, vitamina $\mathrm{C}$, vitamina $\mathrm{E}$ (principal antioxidante lipossolúvel), Vitamina A (antioxidante lipídico) e ácido úrico (inativação do peróxidonitrito) provém a proteção não enzimática do estresse oxidativo e normalmente atuam na cadeia de oxidação da peroxidação lipídica.

Existem vários mecanismos enzimáticos, que atuam durante os processos de estresse oxidativo. A superóxido dismutase (SOD) é uma família de metaloenzima que catalisa a dismutação por meio do peróxido de hidrogênio que é metabolizado pela catalase ou limitando a família das peroxidases (CHANDRA et al., 2000).

$$
2 \mathrm{H} 2 \mathrm{O} 2->2 \mathrm{H} 2 \mathrm{O}+\mathrm{O} 2
$$

A superóxido dismutase cataliza reações similares entre elas.

$$
\mathrm{O} 2-+\mathrm{O} 2-+2 \mathrm{H}+->\mathrm{H} 2 \mathrm{O} 2+\mathrm{O} 2
$$

O termo dismutase descreve um grupo de enzimas que atuam em duas moléculas idênticas que vão resultar em produtos diferentes. O peróxido de hidrogênio formado na reação pode inibir a ação da enzima catalase (LENNINGHER, 2006).

Embora seja um mecanismo de proteção, a produção de radicais livres, causa inúmeras alterações morfofuncionais no organismo da vaca leiteira, como a atividade imunológica, podendo a susceptibilidade a doenças e comprometer o desempenho reprodutivo.

As células imunológicas criam inúmeras espécies reativas de oxigênio e as utilizam como meio para eliminar patógenos. Nos casos de infecções crônicas, a atividade continua de fagócitos leva a superprodução de radicais livres, o que pode contribuir para o dano de membranas celulares. A resposta do organismo ao estresse oxidativo é o aumento na produção e liberação de hormônios, como o cortisol, de enzimas como a creatina fosfoquinase (CK), de neurotransmissores e eicosanóides. Por conseguinte, pode afetar, negativamente, as funções imunológicas e reprodutivas (LEWIS; MCKAY, 2009). Durante os processos metabólicos, na proliferação celular e na defesa contra agentes agressores, também são produzidos radicais livres. Entre estes, pequenas quantidades de espécies reativas de oxigênio (ERO) são constantemente produzidas. A quantidade ideal destes metabólitos é mantida pelo sistema de defesa antioxidante, que evita danos celulares. O dano celular ocorre quando há aumento na produção de ERO e/ou diminuição das defesas antioxidantes (HATAMOTO, 2004). 
Entretanto, não existem estudos que mostrem quais os teores plasmáticos aceitáveis desses marcadores para vacas leiteiras, sem que a saúde e a eficiência reprodutiva sejam afetadas.

O considerável aumento nas exigências de oxigênio durante este período gera um desbalanço das defesas antioxidantes necessário para reduzir a acumulação de ROS durante o período de. Primeiros estudos sugeriram um papel do estresse oxidativo em etiologias dos distúrbios de gado leiteiro, uma vez que a suplementação com certo antioxidante pode amenizar a gravidade de uma variedade de doenças metabólicas e infecciosas (MILLER et al., 1993). Agora há vários estudos mais recentes para apoiar o conceito de que o estresse oxidativo é um fator subjacente significativo para respostas imunes e inflamatórias, particularmente durante o período de transição (ALLISON; LAV, 2000; BERNABUCCI et al., 2005; CASTILLO et al., 2005; WILDE, 2006).

O organismo possui sistemas de defesa antioxidante, que podem ser classificados em primários e secundários. As defesas primárias são constituídas pelas enzimas catalase, superóxido desmutase (SOD) e glutationa peroxidase (GP), que atuam na prevenção e na inativação da ERO, antes destas oxidarem os lipídios. A defesa secundária é constituída pela vitamina E, que atua no reparo e eliminação desses danos (RIVERA et al., 2002; PEETERS et al., 2005).

Uma alternativa é a dosagem de componentes oxidados, como o malondialdeído (MDA), que pode ser usado como um índice de peroxidação lipídica, para vacas leiteiras, durante o período de transição e início de lactação (AITKEN et al., 1993a, b). Um aumento da incidência de doenças durante o periparto está diretamente relacionado com vários fatores genéticos, fisiológicos e ambientais que podem comprometer as defesas imunológicas. $\mathrm{O}$ estresse de oxidativo durante o período de transição pode ser a maior causa de disfunção imune em vacas leiteiras (GITTO et al., 2002; BERNABUCCI et al., 2005; CASTILLO et al., 2005; STEFANON et al., 2005; SORDILLO et al., 1997). O desbalanço de nutrientes altera a população de leucócitos devido a baixas concentrações circulantes de vitaminas e oligoelementos que são necessários para maximizar o potencial antioxidante durante períodos de desafio pró-oxidante (SUTTLE; JONES, 1989; BENDICH, 1993; LANÇAS, 2000). A maioria dos estudos realizados sobre as populações de leucócitos bovinos envolve a suplementação com vitamina E ou selênio (FINCH; TURNER, 1996). Vários estudos mostraram que vacas leiteiras que tinham maiores concentrações plasmáticas da vitamina $\mathrm{E}$ e do Se, possuíam neutrófilos com maior capacidade (GYANG et al., 1984; HOGAN et al., 1990, 1992; GRASSO et al., 1990). As funções dos macrófagos podem ser reforçadas pela suplementação com vitamina $\mathrm{E}$, aumentando principalmente por aumentar a expressão de 
genes relacionados com a interleucina 1 e moléculas de MHC de II (POLITIS et al., 1995). Outros estudos demonstraram que a suplementação in vitro de células mononucleares de sangue periférico de bovinos com o a-tocoferol resultou em um aumento induzido da produção de IgM quando comparado com culturas sem tocoferol (SCHRAMA et al., 1992).

A vitamina E (tocoferol) é lipossolúvel e apresenta importante papel no reparo dos danos causados pelas EROS e também na sua eliminação (HATAMOTO, 2004). Sua suplementação em humanos levou à melhora da glicemia e ação da insulina (PAOLISSO et al., 1993), em bovinos abatidos proporcionou estabilização na cor da carne destes animais por inibição da oxidação de lipídios (FAUSTMAN et al., 1998; GRANIT et al., 2001), em bovinos confinados levou à melhora na resposta imune humoral (RIVERA et al., 2002).

Foi demonstrado, in vitro, que a vitamina $\mathrm{E}$ além de captar os RL, repara, protege membranas celulares (GIROTTI, 1998) e também mantém os níveis da superóxido dismutase no plasma seminal (BECONI et al., 1991). Segundo Bradford et al. (2003) a ação do tocoferol sobre a modulação da atividade enzimática pode ser maior do que a sua ação sobre a estrutura da membrana. Apesar das funções da vitamina E, no sistema antioxidante, serem muito variadas, ela atua em vários outros mecanismos celulares e orgânicos como regulação da transcrição de genes, agregação plaquetária e adesão monocitária (BRADFORD et al., 2003).

A vitamina A possui propriedades anticarcinogênicas e antimutagênicas, é necessária às células epiteliais, ao crescimento ósseo e à visão noturna. Em relação à vitamina $\mathrm{D}$, embora sua principal ação esteja relacionada com o metabolismo do cálcio e fósforo, mantendo os níveis normais destes elementos no organismo, ela também atua no sistema imune (POND, 2005). Baixas taxas de concepção e a mortalidade embrionária até o período do reconhecimento materno embrionário estão estimadas em $15 \%$, no gado leiteiro, que pode chegar até 30\%, quando as vacas estão expostas a um elevado índice de temperatura e umidade e podem estar ligadas as condições de estresse oxidativo aliadas a função imunológica das vacas leiteiras. Nessas condições, pode haver até $8 \%$ de aumento na taxa de mortalidade, entre os 30 e 60 dias, estimada em 28\% (WILTBANK, 2006).

O número de variáveis potencialmente mensuráveis, para determinação do perfil metabólico, hormonal e oxidativo, em vacas leiteiras é grande, entretanto, uma das maiores dificuldades da utilização desta ferramenta é a sua interpretação correta, devido à falta de valores nacionais adequados de referência (GONZÁLES, 1997; GONZÁLES et al., 2000).

Existe, portanto, uma grande necessidade de se determinar os valores de referência, as causas de variação e a relação entre os efeitos destas variações, no comprometimento do 
desempenho produtivo e reprodutivo (MATURANA FILHO, 2009; GONZÁLES et al., 2000).

Muitos esforços estão sendo dispensados, em alguns centros de pesquisa, na condução de projetos voltados à compreensão dos mecanismos que ocorrem durante o período de transição e início de lactação, de vacas leiteiras, mostrando a necessidade de ampliar no Brasil, o número de projetos nesta área.

A complexidade do tema e suas implicações, especialmente econômicas, ligadas à melhoria da saúde, da eficiência produtiva e reprodutiva, exigem o desenvolvimento de modelos de experimentação que expliquem corretamente essas mudanças e que auxiliem na elaboração e aplicação de novas técnicas de manejo para o rebanho leiteiro nacional.

\subsection{Efeitos do estresse calorico, sobre a saúde, o desempenho produtivo e reprodutivo de vacas leiteiras}

O estresse calórico é responsável por perdas econômicas importantes na indústria leiteira mundial. Em uma condição de termoneutralidade ( 0 a $25{ }^{\circ} \mathrm{C}$ para raças européias), a vaca pode manter a homeostasia sem o uso excessivo de energia para regular a temperatura interna, portanto, a energia disponível será dispensada para a manutenção de condições ótimas de saúde e produção (YOUSEF, 1985). Inúmeros estudos têm sido desenvolvidos nas ultimas décadas, enfatizando os efeitos do estresse térmico em sobre a produção, saúde e reprodução de vacas leiteiras (ver revisão por WOLFENSON et al., 2000).

A estratégia básica de termorregulação de um mamífero é o de manter uma temperatura corporal superior a temperatura ambiente, para permitir que o calor seja dissipado através de quatro vias básicas de troca de calor (condução, convecção, radiação e evaporação). Três dessas vias (condução, convecção e radiação) são referidos como vias de perda de calor sensível e necessita de um gradiente térmico. A quarta (evaporação) trabalha em um gradiente de vapor / pressão. Quando as condições de temperatura ambiente se aproximam da temperatura corporal, o único caminho viável para a perda de calor é a evaporação (MCDOWEL, 1975; RAVAGNOLO; MIZTAL, 2002). Portanto, os sistemas de produção, com estabulação para as vacas leiteiras, são capazes de melhorar e controlar parcialmente as suas necessidades de refrigeração. 
Um ponto importante a se considerado no que diz respeito aos efeitos sazonais sobre a saúde e desempenho de vacas leiteiras, são os aumentos observados nas concentrações de prolactina (PRL) sob dias longos em comparação a dias curtos (AUCHTUNG et al., 2003), pois em períodos de maior intensidade de temperatura e umidade, ocorre uma diminuição na abundancia dos receptores desse hormônio (PRLR), o que diminui as respostas, mesmo em períodos de maior secreção. Evidências recentes sugerem que um aumento na expressão de PRLR no parênquima hepático hepática, no tecido mamário, e tecidos imunes de bovinos ocorre em dias curtos, portanto, pode potencializar ações deste hormônio, que além de ter um um papel fundamental na mamogênese, também participa na estimulação na produção de enzimas como a glutationa peroxidase e também na função imune (AUCHTUNG; DAHL, 2004).

A relação entre a PRL com a função imune alterada foi testada em alguns estudos, que revelaram que a sensibilidade das células imunes a PRL eram semelhantes tanto em ensaios in vitro como em estudos in vivo. No estudo de Auchtung e Dahl (2004) foi encontrada uma maior expressão PRLR sob exposição de dias curtos, com o aumento da proliferação de linfócitos, e da quimiotaxia para neutrófilos. Nesse estudo os autores também encontraram uma redução na contagem de células. A confirmação adicional de uma resposta mediada por PRL foi baseada na observação de que a exposição a dias longos, combinadas com tratamento com bromocriptina para diminuir circulante PRL induziu respostas semelhantes às das vacas em dias curtos. Além disso, quando testado em condições in vitro, os linfócitos colhidos de vacas sob dias curtos eram significativamente mais sensíveis do que aqueles para PRL de vacas em dias longos, proporcionando mais apoio para o conceito de que a manipulação fotoperíodo para melhorar a função imune é mediada por alterações na sensibilidade da PRL.

No que diz respeito ao desempenho produtivo de vacas leiteiras durante o estresse térmico, sabe-se que as alterações fisiológicas no sistema digestivo, principalmente as que regulam o equilíbrio ácido básico no rúmen, e a variação hormonal, podem comprometer a ingestão e a absorção (WEST, 2003).

Os neurônios que são sensíveis à temperatura estão localizados em todo o corpo do animal afim de enviar informações para o hipotálamo, que desencadeará um aumento ou em alguns casos a diminuição de estímulos na tentativa de manter o equilíbrio térmico (CURTIS, 1983). Durante o período do verão, as vacas leiteiras exibem reduzida ingestão de alimentos, diminuição da atividade de ruminação e aumentam a taxa respiratória, consequentemente gera uma alteração dos mecanismos acido-básico e que afeta mecanismos celulares. Estas 
respostas ter um efeito deletério sobre a produção e estado fisiológico das vacas (HAYRILI, et al., 2003).

Comparando vacas que foram alimentados ad libitum em ambiente de conforto térmico, ou em um ambiente de estresse térmico, com vacas com restrição alimentar em um ambiente de conforto térmico havia, a produção de leite de leite foi comprometida para os grupos de ingestão restrita e estresse térmico (LOUGH et al., 1990). Para vacas expostas aos tratamentos semelhantes aos do estudo de Lough et al. (1990), outros estudos foram conduzidos, avaliando o fluxo hepático. Foi observada uma redução média de $14 \%$ do fluxo nas vacas em conforto térmico com a ingestão restrita e das vacas submetidas ao estresse térmico, quando comparadas as vacas alimentadas ad libitum dentro de uma com conforto térmico (MCGUIRE et al., 1989). Os autores concluíram que era uma parte dos efeitos negativos do estresse calórico sobre a produção de leite pode ser explicada por uma diminuição da ingestão de nutrientes e conseqüentemente da absorção de nutrientes, aliado a uma diminuição da atividade hepática, pois o fluxo de sangue deslocado para os tecidos periféricos para fins de resfriamento podem alterar o metabolismo de nutrientes e contribuem para a menor produção de leite durante o tempo quente.

Fatores ambientais, especialmente temperatura e umidade, exposição influenciar a saúde e a produtividade das vacas leiteiras durante o início do período de lactação, mas possivelmente muito desses efeitos decorrem de comprometimento gerado desde o período seco. Foi avaliado por Amaral et al. (2009) os efeitos do estresse térmico e do foto período pré-parto estresse sobre o desempenho produtivo durante a lactação e a expressão de alguns genes ligados ao metabolismo hepático de vacas multíparas. Os tratamentos consistiram de tanto estresse térmico (HT) ou resfriamento (CL), com ventiladores e aspersores, tanto sob fotoperíodo de 14L: $10 \mathrm{D}$. A temperatura retal foi medida duas vezes ao dia durante o período seco. Foram retiradas amostras de sangue de metabólitos e também foram feitas biópsias hepáticas para medir a expressão de mRNA de supressores de sinalização de citocinas (SOCS-2 -2), a insuline like growth factor binding protein-5 (IGFBP-5), um fator de transcrição na biossíntese de lipídios (SREBP-1c) e enzimas do metabolismo lipídico (FASN, CACA, e ACADVL). A exposição ao estresse térmico aumentou a temperatura retal (39,2 vs $38,8^{\circ} \mathrm{C}$ ), as concentrações de prolactina no -1 (171 vs $\left.79 \mathrm{ng} / \mathrm{mL}\right)$ e $0 \mathrm{~d}(210 \mathrm{vs} 115 \mathrm{ng} /$ $\mathrm{mL}$ ) e diminui a ingestão de matéria seca a 0 e $14 \mathrm{~d}$ em relação ao parto. A produção de leite corrigido para 3,5\% de gordura também foi inferior (26,1 vs 35,4 kg / d). Em relação a vacas CL, a expressão de mRNA hepático SOCS-2 e IGFBP-5 foi diminuída para as vacas HT. Estes resultados sugerem que a redução do estresse calórico durante o período seco aumenta a 
produtividade na lactação subseqüente, principalmente por uma supressão de prolactina plasmática e uma melhora na regulação do metabolismo lipídico no fígado.

O mecanismo pelo qual o estresse calórico afeta a produção pode ser explicada principalmente pela redução da ingestão de alimentos (COLLIER; BEEDE, 1985). No entanto, outras alterações fisiológicas induzidas pelo calor, inclui um aumento das exigências de manutenção (COLLIER et al., 2005) status e endócrino alterado e ambos podem causar uma diminuição líquida de nutrientes e disponibilidade de energia para a síntese de leite. Estudos recentes demonstraram as concentrações de AGNE não são aumentados em vacas estressadas pelo calor (HS) (SHAWRTZ et al., 2009), apesar de uma redução no consumo de ração (RHOADS et al., 2009). Esta alteração do metabolismo lipídico pós-absortivo, independente de mudanças associadas no consumo de ração, pode ajudar a explicar por que menor ingestão de alimentos não explica totalmente a diminuição da síntese de leite durante o estresse térmico (RHOADS et al., 2009). Além de mudanças no metabolismo lipídico, o estresse calórico altera a estabilidade de carboidratos durante o processo de digestão e absorção (FEBBRARIO, 2001; JENTJENS et al, 2002; WHEELOCK et al., 2010), fornecendo mais evidências de um perturbado ambiente metabólico que pode contribuir para as perdas de produção, principalmente por alterar os mecanismos de ação do GH (BAUMAN; CURRIE, 1980).

Foi mostrado no estudo de Rhoads et al. (2010) que o estresse calórico prejudica a resposta hepática ao $\mathrm{GH}$ em vacas leiteiras submetidas ou não ao estresse calórico. Isto foi comprovado por meio de uma diminuição na abundância de GHR e STAT5 após administração de somatotropina recombinante bovina (rBST). Não houve diferença nas concentrações plasmáticas de GH, no entanto, as concentrações de IGF-1 foram reduzidas, sugerindo que o desacoplamento do eixo GH-IGF pode ocorrer durante o estresse térmico.

Taxas de concepção significativamente menores tem sido observadas em vacas com temperaturas corporais acima de $39,2^{\circ} \mathrm{C}$ no momento da inseminação, normalmente associado com uma baixa de fertilização e uma incidência elevada de mortes embrionárias (FUQUAY, 1981; EDWARD; HANSEN, 1997; AMBROSE et al., 1999; RAVAGNOLO; MIZTAL, 2002; WEST, 2003; HANSEN, 2007). Tanto a viabilidade do oócito, como o potencial de capacitação e fecundação dos espermatozóides são significativamente reduzidos quando a temperatura corporal das vacas leiteiras está mais elevada que $39,2{ }^{\circ} \mathrm{C}$. Altas temperaturas afetam o desenvolvimento de embriões jovens, que são mais vulneráveis nos primeiros dias de vida (FALLON, 1962; STOTT; WILLIANS, 1969; HANSEN, 1997; COLLIER et al., 2006; COLLIER et al., 2008; EDWARD; HANSEN 2007). Há também um efeito negativo 
sobre a incidência e intensidade e duração do estro. Além disso, tem sido observado que o estresse térmico pode impedir ou atrasar a ovulação (HER et al., 1988; EDWARD; HANSEN, 1997; WILSON et al., 1998; COLLIER et al., 2006; JOUSAN; HANSEN, 2007).

No estudo de Wolfenson et al. (2000) foi observado um menor diâmetro do folículo dominante da primeira onda em vacas submetidas ao estresse quando comparado a vacas em uma condição de termoneutralidade. Isso pode ser explicado por uma ineficiência no processo de dominância folicular, devido às baixas concentrações plasmáticas de inibina nessas vacas. Além disso, o estresse térmico reduziu a viabilidade de celulas granulosa, atividade das aromatases, e a produção de androstenediona.

Menores concentrações de estradiol (E2) também são encontradas tanto no plasma como no fluido folicular nas vacas leiteiras no final do verão (COPPOCK; WILKS, 1991).

Alterações no desenvolvimento folicular durante o estresse térmico em vacas em lactação pode interagir com outros componentes do sistema reprodutivo. Por exemplo, o comprometimento da função folículo pré-ovulatório pode afetar a função CL, subseqüentemente a secreção de progesterona (P4), resultando em potenciais alterações de ambientes tubário ou uterino que podem afetar o desenvolvimento do embrião (EDWARD; HANSEN, 1997; WOLFENSON, 2003; PAYTON et al., 2004; COLLIER et al., 2006; COLLIER et al., 2008; HANSEN, 2007). A redução da secreção de P4 a partir de células lútea do CL coletadas no verão contra o inverno (EDWARD; HANSEN, 1997; HANSEN, 2007) pode ser relacionada com a função prejudicada do folículo pré-ovulatório.

Ravagnolo e Misztal (2000) encontraram variabilidade genética suficiente dentro da raça holandesa, para permitir a seleção de animais com bom potencial para a produção de sólidos e com maior tolerância ao calor. Porque a correlação genética entre tolerância ao calor e capacidade de produção foi -0,33, portanto, é possível selecionar para as duas características simultaneamente. Isso também pode ser o caso para características reprodutivas, que parecem ser ainda mais suscetíveis ao estresse térmico do que as características de produção.

Gwazdauskas et al. (2000) verificaram que as duas variáveis mais importantes na determinação da taxa de concepção foram a temperatura máxima no dia após a inseminação. No entanto, Ingraham et al. (1974) constataram que a temperatura média do índice de temperatura e umidade (ITU) $2 \mathrm{~d}$ antes da inseminação artificial teve uma relação maior do que a mesma variável no dia da inseminação e no dia após a inseminação. Muitas características diferentes estão sendo utilizadas para avaliar o desempenho reprodutivo. 


\section{CAPÍTULO 1: DIFERENÇAS METABÓLICAS DURANTE O PERÍODO DE TRANSIÇÃO DE VACAS DE ALTA E MÉdIA PRODUÇÃO NO INVERNO E NO VERÃO}

\subsection{Justificativa e hipótese}

As diferenças metabólicas ocorridas durante o período de transição determinam a produtividade leiteira e a fertilidade nos animais até os 150 dias em lactação.

As hipóteses do presente capitulo são:

1) O padrão de variação metabólica durante o período de transição e inicio de lactação é diferente nas vacas de alta produção, quando comparado a vacas de média produção. Sendo esse padrão, influenciado principalmente, pela estação do ano;

2) Vacas leiteiras que ficam prenhes na primeira inseminação, têm um padrão metabólico semelhante, mesmo em diferentes estações do ano;

\subsection{Objetivos}

O presente estudo tem como objetivo verificar as associações entre variáveis metabólicas durante o período de transição em vacas leiteiras de alta e média produção no inverno e no verão.

\subsection{Objetivos Específicos}

Como objetivos específicos, este trabalho visa:

- Determinar quais pontos de coleta nos períodos pré e pós parto podem ser utilizados para prever as alterações de saúde e fertilidade de vacas leiteiras de alta e média produção, no inverno e no verão; 
- Determinar quais variáveis metabólicas predizem as alterações de saúde e fertilidade de vacas leiteiras de alta e média produção no inverno e no verão;

- Compreender as relações entre o metabolismo protéico, energético, hepático e renal e indicar quais variáveis são preditoras da prenhez no primeiro serviço.

\subsection{Materiais e Métodos}

3.4.1 Vacas, períodos, manejo e nutrição

O experimento foi dividido em duas fases. A primeira parte do experimento ocorreu no inverno (I) e a segunda fase no verão (V). Ambos os períodos foram realizados em uma fazenda comercial (Fazenda Colorado, Brasil, CEP 13600-000), com 245 vacas holandesas multíparas (entre 2 e 4 lactações), com a data do parto definido para 21 dias após o início da avaliação experimental. Durante o período de transição, todas as vacas foram alojadas em estábulo free-stall com ventilação cruzada.

$\mathrm{Na}$ primeira etapa do experimento (inverno), todas as vacas tiveram o seu período de transição entre maio e junho de 2011 e as três primeiras inseminações entre o final de junho até o início de outubro de 2011. Na segunda etapa do experimento (verão), todas as vacas tiveram seu período de transição entre novembro e dezembro de 2011 e as três primeiras inseminações entre o final de dezembro de 2011 e início de março de 2012.

Todas as vacas utilizadas no experimento e que não foram descartadas por problemas de saúde, também foram monitoradas no início de lactação, durante o manejo reprodutivo dos (com inseminação artificial em tempo fixo para primeira inseminação e subseqüentes ressincronizações). As amostras de sangue foram coletadas em pontos de relevância biológica como descrito na figura 1. Durante o período de transição, foram feitas coletas de sangue, avaliação da condição corporal (ECC), o escore de claudicação (ECLAU), e a incidência de doenças de transição (retenção de placenta, metrite, deslocamento de abomaso, cetose).

Os animais foram distribuídos, de forma retrospectiva, de acordo com a produção média de todas as vacas do experimento, durante o pico de lactação ( $4^{\circ}$ a $8^{\circ}$ semanas). A média geral foi de 45,9 $\mathrm{Kg} /$ leite/ dia. Posteriormente, as vacas foram alocadas dentro dos grupos 
experimentais (Alta Produção (AP), $\geq 45,9$ até $65 \mathrm{~kg} /$ leite no Pico de lactação; média Produção (MP), entre 30 e 45,8 kg/leite no Pico de lactação).

As vacas eram alocadas para o galpão a partir de 35 dias da data de parto prevista, para adaptação prévia de 15 dias antes do período de avaliação e também na eventualidade de algum parto ser antecipado. Na média, as vacas pariram com três dias de antecedência em relação à data prevista, de forma que todas as vacas foram adaptadas ao manejo antes do parto previsto.

As dietas foram formuladas de acordo com o NRC (2001), conforme descrito na tabela 2 e as características da dieta, conforme a tabela 3. A ração de transição foi utilizada durante o período pré-parto até 30 dias pós-parto. Após esse período, os animais foram alocados em outros galpões, usando uma única dieta, mudando somente a quantidade oferecida, de acordo com a produção e o consumo de matéria seca (CMS) do lote no dia anterior.

Figura 1 - Caracterização dos pontos de coleta e avaliações reprodutivas nos experimentos de inverno e verão

Período Experimental (Inverno e Verão) \pm 3

\begin{tabular}{|c|c|c|c|c|c|c|}
\hline \multicolumn{5}{|c|}{ Período de Transição } & \multicolumn{2}{|c|}{ Pré-sincronização } \\
\hline \multicolumn{2}{|c|}{ Pré Parto } & \multicolumn{5}{|c|}{ Inicio de Lactação } \\
\hline D-21 & D-7 & Parto & D7 & D21 & D39 & D53 \\
\hline
\end{tabular}

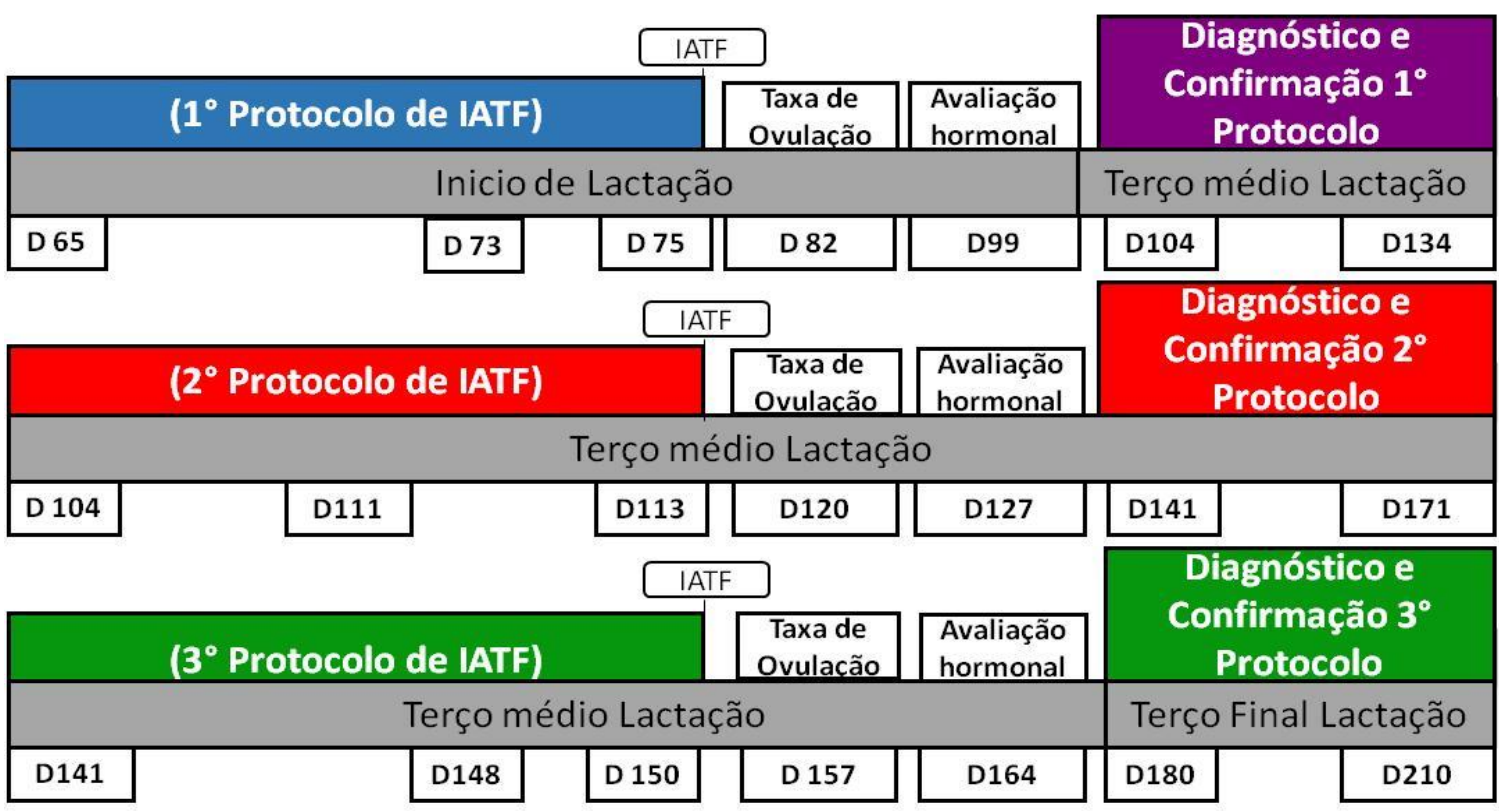

Fonte: (MATURANA FILHO, 2013). 
Tabela 1 - Composição do TMR durante o período de transição e início de lactação

\begin{tabular}{|c|c|c|c|c|}
\hline \multirow[b]{3}{*}{ Ingredientes } & \multicolumn{2}{|c|}{ Pré Parto } & \multicolumn{2}{|c|}{ Pós Parto } \\
\hline & Inverno & Verão & Inverno & Verão \\
\hline & & & $\mathrm{Kg} / \mathrm{MS}$ & \\
\hline $\begin{array}{l}\text { Silagem de Milho 33\% MS } \\
43 \% \text { FDN }\end{array}$ & 7.36 & 7.28 & 6.4 & 6.44 \\
\hline $\begin{array}{l}\text { Pre secado12 PB } 70 \text { FDN } 68 \\
\text { MS }\end{array}$ & 1.125 & 1.4 & - & - \\
\hline Pré secado de Azevém & - & - & 3.12 & 1.575 \\
\hline Caroço de Algodão & 0.46 & 0.46 & 1.38 & 1.38 \\
\hline Polpa Cítrica & 0.455 & 0.46 & 2.276 & 2.73 \\
\hline Milho grão úmido $68 \%$ & 0.93 & 0.93 & 0.931 & 2.294 \\
\hline Milho moído 9\% FDN & - & - & 1.32 & - \\
\hline Farelo de soja $44 \%$ PB & 2.2 & 1.76 & 3.52 & 3.96 \\
\hline Megalac & - & - & 0.098 & 0.098 \\
\hline Água & - & - & 0.01 & - \\
\hline Núcleo Vitamínico 1 & - & - & 0.94 & 1.128 \\
\hline Núcleo Mineral 2 & 0.285 & 0.598 & 0.286 & 0.285 \\
\hline
\end{tabular}


Tabela 2 - Proporção de ingredientes e composição nutricional do TMR oferecido durante período de transição e início de lactação

\begin{tabular}{|c|c|c|c|c|}
\hline \multirow[b]{3}{*}{ Ingredientes } & \multicolumn{2}{|c|}{ Pré Parto } & \multicolumn{2}{|c|}{ Pós Parto } \\
\hline & Inverno & Verão & Inverno & Verão \\
\hline & \multicolumn{4}{|c|}{$\%$ da MS } \\
\hline $\begin{array}{l}\text { Silagem de Milho 33\% MS 43\% } \\
\text { FDN }\end{array}$ & 57.4 & 56.5 & 31.6 & 32.4 \\
\hline Pre secado12 PB 70 FDN 68 MS & 8.8 & 10.9 & - & - \\
\hline Pré secado de Azevém & - & - & 15.4 & 7.9 \\
\hline Caroço de Algodão & 3.6 & 3.6 & 6.8 & 6.9 \\
\hline Polpa Cítrica & 3.6 & 3.6 & 11.2 & 13.7 \\
\hline Milho grão úmido $68 \%$ & 7.3 & 7.2 & 4.6 & 11.5 \\
\hline Milho moído 9\% FDN & - & - & 6.5 & - \\
\hline Farelo de soja $44 \%$ PB & 17.2 & 13.7 & 17.4 & 19.9 \\
\hline Megalac & - & - & 0.5 & 0.5 \\
\hline Água & - & - & 0.04 & - \\
\hline Núcleo Vitamínico 1 & - & - & 4.6 & 5.7 \\
\hline \multirow[t]{2}{*}{ Núcleo Mineral 2} & 2.2 & 4.6 & 1.4 & 1.4 \\
\hline & \multicolumn{4}{|c|}{ Nutrientes \% } \\
\hline Matéria Seca & 43 & 37 & 51 & 48 \\
\hline Matéria orgânica & 92.4 & 92.2 & 92.8 & 92.7 \\
\hline Matéria Mineral & 7.6 & 7.8 & 7.2 & 7.3 \\
\hline Proteína Bruta & 15.3 & 15.6 & 17.5 & 18.3 \\
\hline Extrato etéreo & 2.8 & 2.8 & 4.4 & 4.5 \\
\hline FDN & 46.9 & 46.6 & 35.7 & 35.7 \\
\hline FDA & 29.7 & 29.5 & 21.2 & 21.1 \\
\hline
\end{tabular}

${ }^{1}$ Nutron vitmin - Composição do produto por Kg: Vit, A- 8000UI; vit E - 50000mg; vit D - 2300UI. ${ }^{2}$ Nutron vitabov

- Composição do produto por Kg: Mg-10g; S-9g; Zn-23,750mg; Cu-5625mg; Mn-18125mg; Fe-5,000mg; Co-125mg; I-312mg; Se-144mg; F (max,) 900mg; vit, A- 2000UI; vit E - 12500mg; vit D - 5000UI; MS - Matéria seca; FDN fibra em detergente neutro; FDA - fibra em detergente ácido; PB - proteína bruta; 
Tabela 3 - Parâmetros nutricionais do TMR durante o período de transição e (d $-21 \pm 3$ a d $21 \pm 3$ ) e no início de lactação (depois do período de transição até d $150 \pm 3$ )

\begin{tabular}{|c|c|c|c|c|}
\hline \multirow[b]{2}{*}{ Parâmetros Nutricionais } & \multicolumn{2}{|c|}{ Período de transição } & \multicolumn{2}{|c|}{ Inicio de lactação } \\
\hline & Inverno & Verão & Inverno & Verão \\
\hline PM Bacteria: (g/dia) & 853 & 820 & 1255 & 1229 \\
\hline PM não degradável rúmen: (g/dia) & 362 & 529 & 1020 & 997 \\
\hline PM\% - Bacteriana: (\%) & 70.2 & 60.8 & 55.2 & 55.2 \\
\hline Metionina (\%PM): (\%) & 2.2 & 1.8 & 1.9 & 1.9 \\
\hline Lisina (\%PM): $(\%)$ & 7.1 & 6.1 & 6.4 & 6.5 \\
\hline Balanço de N ruminal: (g/dia) & 54 & 42 & 100 & 125 \\
\hline Balanço de Peptídeos: (g/dia) & 38 & 29 & 72 & 84 \\
\hline NDT: $(\% \mathrm{MS})$ & 78 & 75 & 78 & 79 \\
\hline EM: (Mcal/kg MS) & 2.5 & 2.4 & 2.7 & 2.7 \\
\hline EL: (Mcal/kg MS) & 1.6 & 1.5 & 1.7 & 1.75 \\
\hline Elm: (Mcal/kg MS) & 1.6 & 1.55 & 1.7 & 1.75 \\
\hline peFDN: $(\% \mathrm{MS})$ & 30 & 32 & 25 & 24 \\
\hline Forragem na ração: (\%MS) & 66 & 67 & 44 & 40 \\
\hline Total CNF: $\%$ & 41 & 37 & 39 & 40 \\
\hline Cálcio: \% MS & 0.55 & 0.8 & 0.8 & 0.9 \\
\hline Fósforo: \% MS & 0.4 & 0.4 & 0.4 & 0.5 \\
\hline Magnésio: \% MS & 0.3 & 0.4 & 0.3 & 0.45 \\
\hline Potássio: \% MS & 1.2 & 1.5 & 1.3 & 1.5 \\
\hline Sódio: \% MS & 0.1 & 0.1 & 0.2 & 0.3 \\
\hline Cloro: \% MS & 0.2 & 0.9 & 0.1 & 0.2 \\
\hline Enxofre: \% MS & 0.1 & 0.4 & 0.1 & 0.2 \\
\hline Cobalto: PPM & 1 & 1.04 & 0.9 & 1.04 \\
\hline Cobre: PPM & 17.8 & 17.6 & 19.7 & 21.7 \\
\hline Iodo: PPM & 0.4 & 0.5 & 0.7 & 0.8 \\
\hline Manganês: PPM & 55.6 & 46.4 & 76.7 & 86.5 \\
\hline Selênio: PPM & 0.3 & 0.3 & 0.4 & 0.5 \\
\hline Zinco: PPM & 55.6 & 46.4 & 81.2 & 92.1 \\
\hline Vitamina A: UIK/d & 143 & 150 & 227 & 243 \\
\hline Vitamina D: UIK/d & 41 & 42 & 63 & 68 \\
\hline Vitamina E: UI/d & 1853 & 1993 & 2308 & 2391 \\
\hline
\end{tabular}


3.4.2 Coletas de sangue, avaliação da saúde, análises metabólicas

As coletas de sangue e as avaliações foram realizadas em vários dias, desde o período pré parto até os 150 dias de lactação, visando elucidar as relações existentes entre os processos metabólicos, com a saúde e com a fertilidade, no inverno e no verão, conforme figura 1 .

Para realizar as coletas de sangue e as avaliações, todas as vacas eram contidas no canzil de alimentação, após retornarem da primeira ordenha da manhã. As vacas no galpão de pré parto também eram contidas no canzil, após ser realizado a primeira alimentação do dia. Vacas que tinham alguma dificuldade de locomoção, ou que estavam deitadas ruminando, eventualmente, as coletas eram realizadas na cama do freestal.

No manejo das vacas durante o período pré-parto, foram realizadas, coletas de sangue para analises de metabólitos e para o hemograma. Além disso, também eram realizadas as avaliações do escore de condição corporal (ECC -1 a 5), conforme metodologia descrita por por Fergunson et al. (1994).

Ainda, no manejo no galpão de transição da fazenda, todas as vacas no pré parto foram monitoradas 24 horas, sendo os partos acompanhados, de modo que, caso fosse necessário, intervenções seriam realizadas.

No dia do parto ou até 48 horas após, era coletada uma amostra de sangue e coletadas as informações do parto (distocias, retenção de placenta, peso e sexo da cria e produção de leite) e as avaliados ECC e ECLAU.

No dia $10( \pm 3)$ após o parto, eram realizadas as coletas de sangue, avaliados o ECC e o ECLAU e também eram coletadas as informações de saúde (ocorrência de mastite, deslocamento de abomaso, animais tratados para cetose ou hipocalcemia, ocorrência de metrite, ocorrência de mortes ou de descartes). A Metrite foi definida como a presença de descarga uterina aquosa, rosa / marrom e fétida. Vacas com sintomas de metrite e temperatura retal $>39,5^{\circ} \mathrm{C}$, com queda de mais de $15 \%$ na produção de leite em relação a 3 anteriores a avaliação e deprimidas, foram consideradas como tendo metrite aguda (LEBLANC, 2010; SILVA et al., 2013).

No dia $21( \pm 3)$ após o parto também eram realizadas as coletas de sangue e as avaliações do ECC e do ECLAU e também eram coletadas as informações de saúde (ocorrência de mastite, deslocamento de abomaso, animais tratados para cetose ou hipocalcemia e as ocorrências ocorrência de mortes ou de descartes). 
No dia $39( \pm 3)$ e no dia $53( \pm 3)$, as vacas foram palpadas para avaliação da presença de corpo lúteo. Todas vacas receberam nesses dias de avaliação, uma dose prostaglandina (como parte do protocolo de pré sincronização), seguido da aplicação de um dispositivo para detecção de estro (estrotec).

Durante os protocolos de IATF (conforme esquema da figura 1), foram coletadas amostras de sangue das vacas e avaliados o ECC e o ECLAU.

As amostras de sangue foram colhidas em dois tubos de $10 \mathrm{ml}$ (vacutainer) contendo solução anticoagulante (heparina) para preparar os eritrócitos, para a análise das concentrações da enzima superóxido dismutase; também dois tubos de $10 \mathrm{ml}$ sem anticoagulante foram coletados e divididos e alíquotas, para análise dos metabólitos (glicose, uréia, AGNE, BHB, albumina, proteína total, AST, GGT), hormonal (progesterona, estradiol, cortisol) e um tubo de $5 \mathrm{ml}$ EDTA foi coletado para hematologia.

Todas as amostras foram colhidas por punção dos vasos da região coccígea e imediatamente após a colheita, foram refrigeradas e no laboratório foram centrifugadas a 2000 g durante 15 minutos para separar o plasma / soro (segundo tubo). O plasma e o soro foram transferidos para criotubos de $1,5 \mathrm{ml}$, identificadas e armazenadas a $-20^{\circ} \mathrm{C}$ até as análises laboratoriais.

Para as amostras que foram destinadas as análises das concentrações da enzima superóxido dismutase, preparou-se uma solução de eritrócitos com uma solução tampão. Após a centrifugação de plasma heparinizado a $4{ }^{\circ} \mathrm{C}, 2000 \mathrm{~g}$ durante 15 minutos, as hemácias foram separadas em duas alíquotas e o restante da amostra foi descartado juntamente com leucócitos. Adicionado aos tubos de tampão e homogeneizar ser identificado. Depois disso, centrifugou-se outra vez com a solução de plasma e o procedimento foi repetido por mais 2 ou 3 vezes até que a amostra não está apresentasse mais leucócitos placa. Estas amostras foram aliquotadas em frascos âmbar e armazenado num congelador a $-80^{\circ} \mathrm{C}$, durante um período máximo de 35 dias.

Para avaliar o perfil oxidativo foram determinadas as concentrações séricas da enzima superóxido dismutase (SOD), com o kit de diagnóstico Randox (SD125 pelo método colorimétrico descrito por BEUTLER et al. (1963), no Laboratório de Doenças Nutricionais, Departamento de Medicina Clínica FMVZ / USP.

Todas as análises sanguíneas foram feitas em um analisador bioquímico automático Randox Daytona ${ }^{\circledR}$ - Randox Laboratories, Reino Unido.

A determinação dos teores plasmáticos de proteína total foi feito pelo método de biureto, de acordo com a técnica recomendada por Gornall et al. (1949) e modificado por 
Capítulo 1 -Diferenças metabólicas durante o período de transição

Strufaldi (1987), com a leitura da reação de coloração, utilizando um comprimento de onda de $550 \mathrm{~nm}$ no analisador bioquímico automático, utilizando um kit comercial (referência Randox PT4001).

A determinação dos teores plasmáticos de albumina foi feita pelo método de verde de bromocresol, utilizando um kit comercial (Randox AB3800) de acordo com a técnica recomendada por Doumas et al. (1971).

A determinação dos teores plasmáticos de globulinas foi obtido subtraindo-se os níveis séricos de proteína total e albumina, e os valores são expressos em g / L. Com a determinação dos níveis séricos de globulinas, albumina foi dividido por globulinas obtenção da relação entre as variáveis.

A determinação dos teores plasmáticos da aspartato aminotransferase (AST) e da gama glutamil transferase (GGT) foram realizadas por metodologia cinética, usando os kits comerciais Randox AST 3804 e Randox GGT 3817, respectivamente.

A determinação dos teores plasmáticos da enzima creatina quinase (CK) foi realizada por analise cinética, de acordo com a metodologia recomendada pela Deutsche Gesellschaft fur Klinische Chemie, usando o kit comercial Randox CK NAC 110.

A determinação dos teores plasmáticos de colesterol foram feitas pelo método colorimétrico enzimático, utilizando um kit comercial (Randox CH3810), de acordo com o método descrito por Allain, et al. (1974).

A determinação dos teores plasmáticos de triglicerídeos foram realizadas pelo método colorimétrico enzimático, utilizando um kit comercial (Randox TR3823), de acordo com a técnica descrita por Fossati et al. (1982).

Os teores plasmáticos dos ácidos graxos não esterificados (AGNE) e de betahidroxi butirato foram medidos pelo método colorimétrico enzimático, usando o kit Randox FA115 e Randox RB 1007, respectivamente.

Para determinação dos plasmáticos de glicose, foi realizada analise automatizada, de acordo com metodologia descrita por Barhan et al. (1972), utilizando o kit comercial Randox GL3815.

A determinação dos teores plasmáticos de uréia foi realizada pelo método de cinética enzimática, utilizando um kit comercial de Randox UR3825 @ marca de referência. Os teores de nitrogênio uréico no sangue foi obtido dividindo os valores de ureia por 2,15.

A determinação dos teores plasmáticos de creatinina foi realizada pelo método colorimétrico e a intensidade de cor processado pelo analisador bioquímico automático, utilizando um kit comercial (Randox CR3814). 
3.4.3 Analises estatísticas

As análises estatísticas foram realizadas utilizando o programa SAS versão 9.3 (SAS / STAT ®, SAS Inst. Inc., Cary, NC, 2012).

Foram trabalhados dois modelos estatísticos para avaliar as variações dos parâmetros metabólicos e de produção. Em um dos modelos estatísticos, o grupo alta produção (AP) e média produção (MP), dias (-21 a 157), o período de inverno (I) e verão (V) e as interações entre eles foram os fatores incluídos no modelo fixo. A vaca foi incluída como efeito aleatório. No segundo modelo, voltado a elucidar as diferenças metabólicas e produtivas que afetaram a fertilidade nos dois períodos, a prenhez no primeiro serviço, bem como a vaca não ficar prenhe na inseminação realizada aos 150 dias de lactação foi o modelo animal usado para separar os grupos, levando em consideração também, os efeitos de período e as interações entre estes fatores continuaram sendo utilizados e também foram incluídas no modelo fixo. A vaca também foi incluída como efeito aleatório.

As variáveis metabólicas: proteína total (PT), albumina (ALB), globulina (GLOB), albumina: globulina (AGR), gama glutamil transferase (GGT), aspartato aminotransferase (AST), creatina quinase (CK), glicose (GLU), colesterol total (CT), triglicérideos (TG), lipoproteína de alta densidade (HDL), lipoproteína de baixa densidade (LDL), lipoproteína de muito baixa densidade (VLDL), colesterol total: HDL (TCHDL), LDL: HDL (LDLH) uréia (UR), nitrogênio uréico no sangue (BUN), a creatinina (CREA), beta hidroxibutirato (BHBA), ácidos graxos não esterificados (AGNE), superóxido dismutase (SOD), foram avaliadas utilizando PROC MIXED (SAS, 2012), usando um modelo linear misto para as medidas repetidas.

Para análise destes dados foi considerado o seguinte modelo:

$y i j k l=m+a j+b i+(a b) i j+e i j k l$

em que:

yijkl é o valor observado

m é uma constante inerente a todas as observações;

aj é o efeito do j-ésimo período ( $\mathrm{j}=\mathrm{I}, \mathrm{V}$ ) considerado fixo;

bi é o efeito do i-ésimo grupo (i= AP, MP)

cl é o efeito do l-ésimo de dias $(1=-21,-7 \ldots$.

(abc)ijl é o efeito da interação entre o i-ésimo grupo e o j-ésimo período, 1-ésimo de dias eijkl é o erro aleatório associado à observação yijkl 
Todos os dados obtidos, foram submetidos a análise de homogeneidade de variância e normalidade dos resíduos (Shapiro-Wilk), de modo que foram excluídos ou transformados todos os out-Liers, quando necessário.

Os dados estão expressos pela média como medida de tendência central, e o erro padrão da média como medida de dispersão. O nível de significância utilizado para rejeitar a hipótese H0 (hipótese nula) para todos os dados obtidos foi $\mathrm{P}<0,05$ e tendências estatísticas como $\mathrm{P}$ $<0,10$ foram consideradas na discussão dos resultados.

\subsection{Resultados e Discussão}

\subsubsection{Metabolismo protéico e globulinas}

Houve efeito de grupo $(\mathrm{P}=0,009)$, dia $(\mathrm{P}<0,0001)$ e interação entre grupo $\mathrm{x}$ dia $(\mathrm{P}$ $<0,0001)$, grupo $\mathrm{x}$ dia $(\mathrm{P}=0,002)$, dia $\mathrm{x}$ período $(\mathrm{P}<0,001)$ e grupo $\mathrm{x}$ dia $\mathrm{x}$ período $(\mathrm{P}$ $<0,001$ ), para concentrações da variável PT (Figura 2A). Houve uma tendência de efeito período para esta variável $(\mathrm{P}=0,1)$. Houve efeito de grupo $(\mathrm{P}=0,04)$, dia $(\mathrm{P}=0,003)$, dia $\mathrm{x}$ período $(P<0,001)$ e tendência de interação entre grupo $x$ tempo $(P=0,09)$, Não houve interação entre grupo x dia x período grupo x dia $(\mathrm{P}=0,16)$, para concentrações da variável PT em vacas que ficaram prenhes ao primeiro serviço, ou vazias a inseminação aos 150 DEL (Figura 2B).

Os teores plasmáticos de PT diminuíram até o parto para todos os grupos, exceto para MPV, que tinha aumentado gradualmente desde o primeiro dia - 7. No grupo APV os níveis de PT foram maiores durante a transição e menor durante o pico de lactação. As vacas que ficaram vazias no verão apresentaram um padrão de variação da proteína total diferente dos demais grupos (de acordo com a prenhez) durante o período pré parto, entretanto, a partir de 7 dias de lactação se assemelhou as vacas que ficaram prenhes no mesmo período. Durante o período de transição a correlação entre os períodos foi apenas de grandeza. No início do período de transição cada período seguiu um padrão bem semelhante, mas durante o pico de lactação esse padrão foi diferente entre prenhes e vazias de ambos os períodos, embora não tenham ocorrido diferenças de tempo. 
Os maiores níveis de PT observados durante o período de transição para ambos os grupos no período de verão pode ser explicado por um estado fisiológico mais próinflamatório devido ao aumento das concentrações de GLOB e da relação menor AGR nestas vacas durante o inicio do período pós parto.

No presente estudo não foi observada nenhuma diferença nas variações do proteinograma, entre vacas que tiveram ou não retenção de placenta, o que está de acordo com Chassagne e Barnouin (1992), que reportaram que os teores plasmáticos de proteína total não diferente entre vacas com retenção de anexos fetais com vacas sadias no dia do parto. Entretanto, os valores de 8,57 \pm 1,37 g/dL (vacas com retenção de placenta) e 7,65 $\pm 1,21$ $\mathrm{g} / \mathrm{dL}$ (vacas com parto fisiológico) do estudo citado, foram mais elevados do que a média da maioria dos grupos experimentais do presente estudo (API, MPI, MPV).

Assim como nos achados do presente estudo e dos achados de Saut (2004), Gonçalves e Kozicki (1997) também evidenciaram que no puerpério de vacas leiteiras, há uma redução significativa das concentrações de proteínas. Os valores encontrados foram de 7,0 $\pm 1,1 \mathrm{~g} / \mathrm{dL}$ no dia do parto para $5,8 \pm 1,0 \mathrm{~g} / \mathrm{dL}$ e $6,5 \pm 1,0 \mathrm{~g} / \mathrm{dL}$, o que está mais próximos dos no $3^{\circ}$ e $5^{\circ}$ dias após a parição, respectivamente.

Os teores médios de proteína total encontrados no presente estudo estão em conformidade com valores relatados para vacas da raça holandesa no Brasil $(84,5 \pm 18,8$ mg/dL, (GONZÁLES et al., 1996); e 77,6 \$12,96 mg/dL em vacas durante o período de transição, (Maturana Filho, 2009), entretanto, Kumar et al. (2001) relataram os valores plasmáticos de proteína total, mais elevados, em vacas no estágio final de lactação, $1^{\circ}$ semana e 2 meses pós-parto. Os valores médios para proteína total foram, respectivamente, 10,33 g/dL, 9,35 g/dL e 8,64 g/dL. Uchida, Katoh e Takahashi (1993) dosaram os teores séricos de proteína total no periparto de 42 vacas Holandesas com partos eutócicos e não observaram diferenças entre as concentrações deste metabólito durante o período de transição. Já no estudo de Nath et al. (2005) ocorreu um aumento da proteína total durante o período close-up, seguido por diminuição a partir do parto, que foi associado a um aumento na concentração de proteína total na fase final de gestação à síntese da fração globulina (essencial para a síntese de colostro), e a abrupta diminuição da concentração de proteína total, no dia do parto, à transferência de globulinas para a glândula mamária na vaca.

Alguns estudos como o de Hirvonen et al. (1999) evidenciaram um aumento de proteína total em vacas holandesas no pós-parto, de vacas holandesas que desenvolveram metrite aguda. Mas esse aumento na proteína total estava associado a um aumento das proteínas de fase aguda como a haptoglobina e a $\alpha 1$-glicoproteína ácida, que corrobora com os dados de 
Cairoli et al. (2006). Em ambos os estudos, foram observados dos teores séricos de $\alpha 1$ glicoproteína ácida e haptoglobina no pós-parto de vacas com endometrite, sendo que os valores de $\alpha 1$-glicoproteína ácida permaneceram aumentados todo o período de transição. Embora não tenham sido estudadas as proteínas de fase aguda no presente estudo, o mesmo padrão ocorrido nos estudos supracitados também foi observado para as vacas de média produção e para as vazias aos 150 DEL em ambas as estações. Além destes grupos, também as vacas de alta produção no verão apresentaram padrão semelhante.

No presente estudo não foram observadas diferenças nos teores séricos de proteínas totais entre vacas prenhes e não prenhes $(\mathrm{P}>0.05)$, que é um achado diferente do estudo de Silva (2009). Entretanto, essas diferenças podem ser explicadas pelo modelo animal utilizado em cada estudo, sendo os do presente estudo vacas não repetidoras de cio na lactação anterior, enquanto que no estudo de Silva (2009) eram utilizadas primiparas que ficaram prenhes nos primeiros cinco serviços. Portanto, o desafio metabólico, o numero de lactações e a alta produção leiteiras das vacas deste experimento podem ser os fatores cruciais para explicar essas diferenças no proteinograma, o que está de acordo com Kaneko et al., (1997).

Figura 2 A - Variação da concentração de proteína total (PT) (mg/dL) no soro de vacas de alta (AP) e média (MP) produção, no inverno (I) e no verão (V)

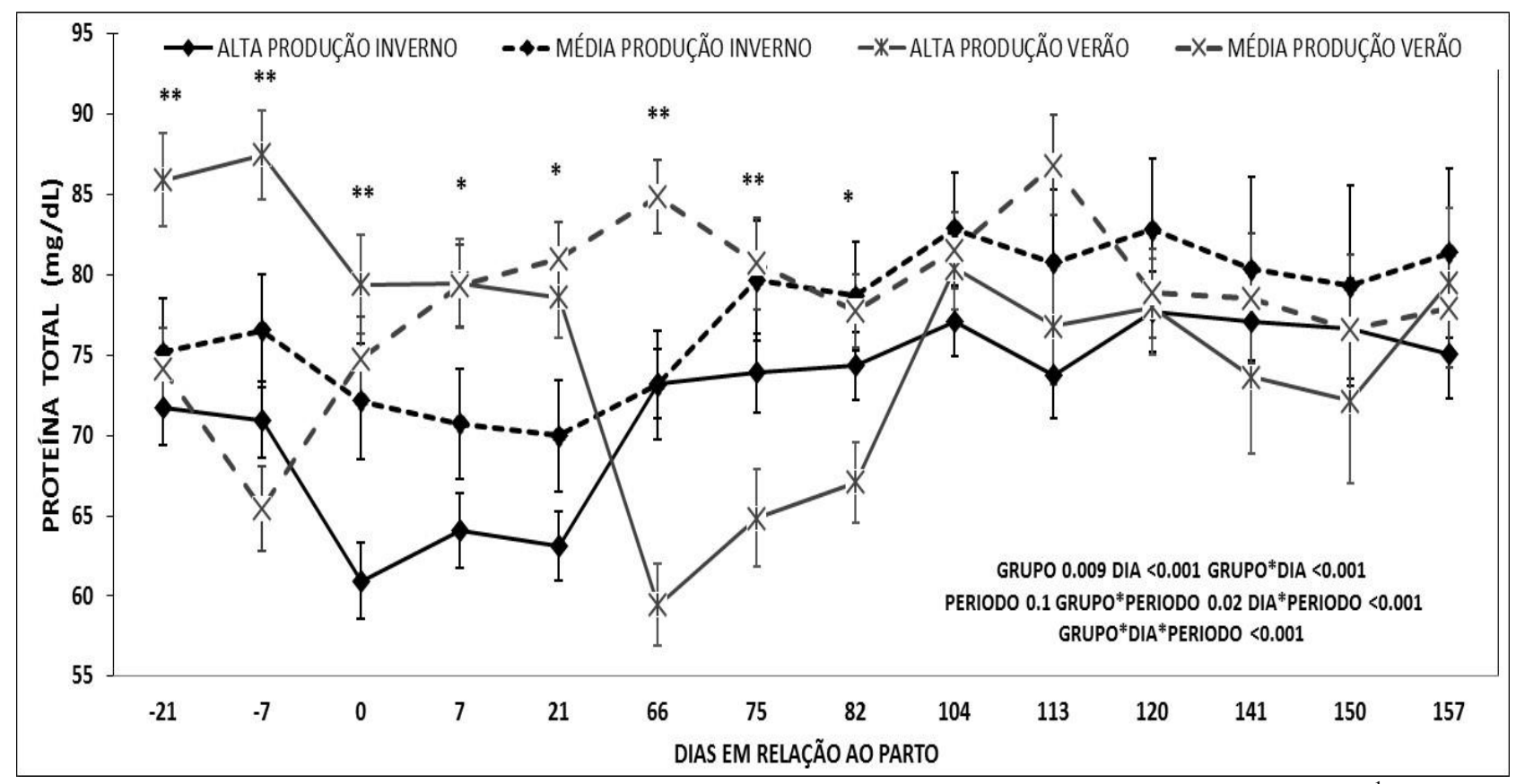

* $\mathrm{P}<0,05, * * \mathrm{P}=0,001, * * * \mathrm{P}<0,001$ para as comparações no período de transição e início da lactação. $\mathrm{AP}^{1}(>45.9$

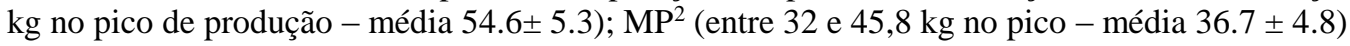


Figura 2 B - Variação da concentração de proteína total (PT) (mg/dL) no soro das vacas leiteiras prenhes à primeira IATF ou vazias aos 150 DEL no inverno (I) e no verão (V)

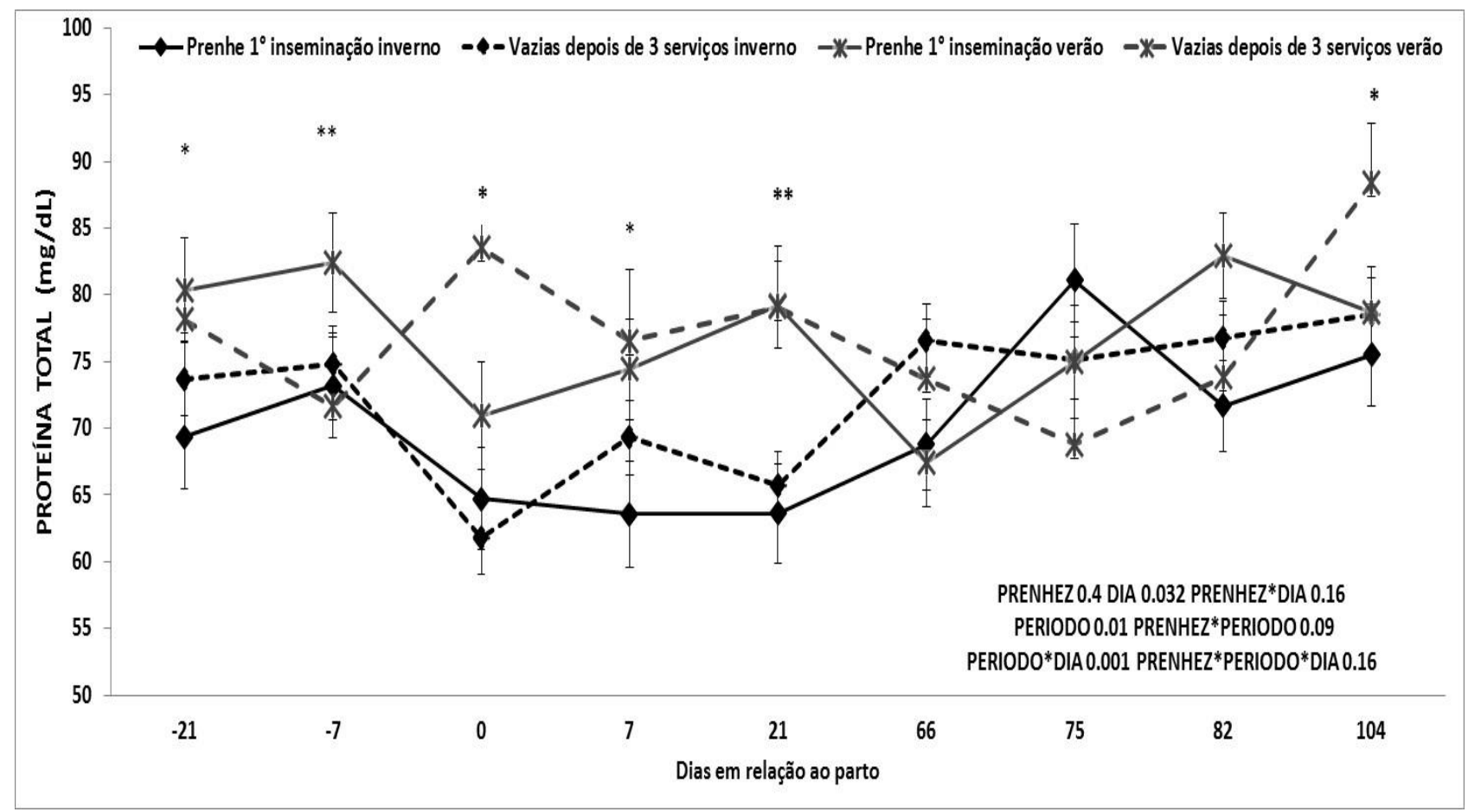

$* \mathrm{P}<0,05, * * \mathrm{P}=0,001, * * * \mathrm{P}<0,001$ para as comparações no período de transição e início da lactação. $\mathrm{AP}^{1}$

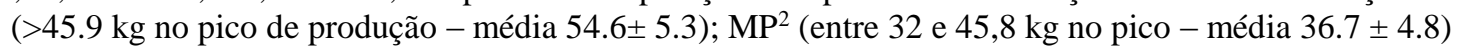

Um efeito de grupo $(\mathrm{P}=0,007)$, dia $(\mathrm{P}=0,005)$ e as interações entre grupo $\mathrm{x}$ dia $(\mathrm{P}=$ 0,009), grupo $\mathrm{x}$ período $(\mathrm{P}=0,03)$, dia $\mathrm{x}$ período $(\mathrm{P}<0,0001)$ e grupo $\mathrm{x}$ dia $\mathrm{x}$ período $(\mathrm{P}=$ 0,003), foi observado para as concentrações da ALB variável (Figura 3A). As alterações nas concentrações séricas de ALB seguiram um padrão semelhante de variação para o PT. Um padrão diferente dos grupos de produção foi observado para os grupos de fertilidade em ambos os períodos, como observado para os teores de PT. Não houve efeito de grupo de prenhez $(P=0,42)$, interação entre grupo de prenhez $x$ dia $(P=0,2)$, entre grupo de prenhez $x$ tempo $(\mathrm{P}=0,6)$, bem como entre grupo de prenhez $\mathrm{x}$ dia $\mathrm{x}$ período $(\mathrm{P}=0,6)$. Houve efeito dia ( $\mathrm{P}=0,002)$, período $\mathrm{x}$ dia $(\mathrm{P}=0,001)$, para concentrações da ALB variável (Figura 3B).

Houve efeito de grupo $(\mathrm{P}=0,001)$, dia $(\mathrm{P}<0,001)$ e interação entre grupo $\mathrm{x}$ dia $(\mathrm{P}=$ $0,001)$, grupo $\mathrm{x}$ tempo $(\mathrm{P}=0,003)$, dia $\mathrm{x}$ período $(\mathrm{P}<0,0001)$ e o grupo $\mathrm{x}$ dia $\mathrm{x}$ período $(\mathrm{P}=$ 0,003), para concentrações da GLOB variável (Figura 4A). Houve uma tendência de interação de efeito período $(\mathrm{P}=0,1)$ para esta variável de acordo com o modelo de grupo de produção. Houve efeito de dia $(\mathrm{P}=0,01)$, período $(\mathrm{P}=0,009)$ e interação entre período $\mathrm{x}$ dia $(\mathrm{P}=0,009)$ e tendência de efeito grupo de prenhez x período $(\mathrm{P}=0,1)$ e grupo de prenhez $\mathrm{x}$ dia $\mathrm{x}$ período 
(P 0,1), para concentrações da GLOB variável (Figura 4B). Não houve efeito isolado de grupo de prenhez $(\mathrm{P}=0,48)$.

Houve efeito de grupo $(\mathrm{P}=0,009)$, dia $(\mathrm{P}<0,0001)$ e interação entre grupo $\mathrm{x}$ dia $(\mathrm{P}$ $<0,0001)$, grupo $\mathrm{x}$ tempo $(\mathrm{P}=0,003)$, dia $\mathrm{x}$ período $(\mathrm{P}<0,05)$ e grupo $\mathrm{x}$ dia $\mathrm{x}$ período $(\mathrm{P}$ $<0,001$ ) para AGR (Figura 4). Houve uma tendência de efeito de períodopara esta variável (P $=0,1)$. Houve efeito de dia $(\mathrm{P}=0,003)$ e interação entre período x dia $(\mathrm{P}=0,005)$ para AGR no modelo animal baseado na fertilidade. Não houve efeito de grupo de prenhez $(\mathrm{P}=0,23)$, período $(P=0,61)$ e interações entre grupo de prenhez $x$ dia $(P=0,25)$, grupo de prenhez $x$ período $(\mathrm{P}=0,4)$ e grupo de prenhez x período x dia $(\mathrm{P}=0,44)$ para esta variável.

A diminuição nas concentrações de albumina e aumento das globulinas no inicio de período pós-parto nas vacas do experimento de verão provavelmente está ligada a maior incidência de retenção de placenta observada nesse período e ao acumulo de triglicerídeos no parênquima hepático. Esses achados corroboram com o estudo de Saut (2004), onde foi verificado que vacas leiteiras com retenção de placenta, a albumina comportou-se como proteína de fase aguda negativa, tendo uma diminuição significativa a partir do parto, acompanhada de haptoglobina, ceruloplasmina e glicoproteína ácida. De acordo com os estudos de Reid (1982) e Strang et al., (1998), existe uma correlação negativa entre a concentração de lipídeos hepáticos e a concentração de albumina no sangue, que está associada aos danos que ocorrem no retículo endoplasmático rugoso. Estes dados também estão em concordância com os estudos de Wagner (1989) e Chassagne e Barnouin (1992) que encontraram uma alta correlação da albumina com os teores plasmáticos de cálcio e ácidos graxos poliinsaturados em vacas com doenças puerperais como retenção de placenta e metrite.

Embora não tenha sido medida a quantidade de triglicerídeos no fígado no presente estudo, de acordo com os estudos de Gonçalves e Kozicki (1997) e de Strang et al. (1997), uma diminuição de mais de $20 \%$ da quantidade de albumina no plasma de vacas no inicio de lactação, juntamente com os aumentos de triacilglicerol, característico de lesão e infiltração lipídica. Portanto, o fato das vacas com mais baixa produção de ambas as estações (MPI e MPV) terem apresentado uma menor relação albumina: globulina no inicio do período pósparto, elucida a hipótese de que a produtividade leiteira altera os teores de proteína total e interfere na saúde hepática desses animais (caracterizado por altas concentrações de proteína total e baixa concentrações de albumina), o que está de acordo com Sugio et al. (1999); Suzuki et al. (2006) e Farrugia (2010).

No estudo de Gonçalves e Kozicki (1997), a relação albumina/globulinas no período pós parto também decresceu (de 1,3 para 0,3) em vacas que tiveram problemas de parto, 
retenção de placenta ou metrite, mas que não apresentaram cetose clinica. Entretanto, de acordo com Birgel e Grunert (2001), quando a relação albumina globulina nas primeiras semanas de lactação é que 0,5 já é considerado um indicativo de alteração hepática e cetose (GRUNERT et al., 2005).

No entanto, somente o acumulo de triglicerídeos hepáticos não seria o único fator metabólico ligado a diminuição da síntese de albumina. Foi verificado em estudos desenvolvidos com cultura de hepatócitos que as taxas basais de síntese de albumina e proteína não foram afetadas somente pelo acumulo de triglicerídeos na célula, mas que a existe um papel fundamental da insulina e do glucagon. Nesse estudo citado, Strang et al. (1997) adicionaram insulina e glucagon na cultura de hepatócitos 12-72 h após plaqueamento, o que aumentou das taxas de síntese de albumina e de proteínas. Neste mesmo estudo foi observado que hepatócitos carregados com triglicerídeos são menos sensíveis à estimulação hormonal para síntese de albumina, mas que em hepatócitos normais (sem infiltração lipídica), a estimulação hormonal com insulina e o glucagon são responsáveis por estimular um aumento na taxa de síntese de albumina. Em hepatócitos com deposição de triglicerídeos, as taxas de depuração de insulina também foram menores, que esse controle hormonal que está ligado a etiologia de distúrbios metabólicos, associadas com o fígado gorduroso, podem ser minimizados quando utilizada uma dieta mais energética durante o período de transição, por exemplo, utilizando fontes de gordura. Está afirmação se apóia nos achados dos estudos de Waltner et al. (1993); Drakcley et al. (1999); Schoeder et al. (2002); Duske et al. (2009), Maturana Filho (2009); Osborne et al. (2009) e Gandra (2012).

O perfil sérico de albumina e de proteínas totais do estudo de Silva (2009) foi semelhante ao do presente estudo, mesmo o modelo animal ter sido vacas primiparas. Entretanto, foi observado um menor teor sérico de albumina e proteína aos 15 dias após o parto, que foi relacionado ao baixo consumo de alimentos aqueles animais, o que também pode explicar parte dessas mudanças nos teores de albumina. Pois de acordo com Kaneko et al. (1997) e Grummer e Kulick (2006), a redução (em torno de 30\%) no CMS ocorrida durante o período de transição levaria a essa diminuição do turnover hepático de albumina, devido a uma baixa de insulina na circulação. Kumar et al. (2001) relataram os valores plasmáticos de globulinas, em vacas no estágio final de lactação, $1^{\circ}$ semana e 2 meses pósparto de bem mais elevados do que os encontrados no presente estudo e nos estudos de Maturana Filho (2009) e Gandra (2012), que foram de 5,66 g/dL, 5,40 g/dL e 3,69 g/dL, respectivamente. Karsai e Schäfer (1984) também demonstraram haver na fase do periparto uma diminuição dos valores de albumina, observados entre a $6^{\circ}$ e $4^{\circ}$ semana antes do parto e os valores em amostras colhidas entre o $1^{\circ}$ e $5^{\circ}$ dia do puerpério. 
Os resultados estão de acordo com Blum et al. (1983) e Cozzi et al. (2013), que verificaram que as concentrações de proteínas totais e globulinas tendiam a ser maior em vacas de 3 a $5^{\circ}$ lactação, sendo que este foi um critério de seleção para a entrada de vacas no presente experimento. Além disso, os mesmos parâmetros sanguíneos também foram maiores no verão. A concentração de albumina nos estudos supracitados também foi afetada pela períododo ano, mas não foi uma consequiência da desidratação, pois as vacas eram todas mantidas estabuladas. É mais provável que o os maiores valores registrados no verão de globulina, como bem como para a creatinina (que será discutida mais adiante, no tópico referente ao perfil renal), caracteriza uma resposta metabólica da vaca no inicio do período de lactação a um ambiente com índice de temperatura e umidade (ITU) mais elevado. Alguns estudos evidenciaram que durante períodos de estresse térmico, ocorre um aumento do catabolismo de AA para a energia (RONCHI et al, 1999; ABENI et al., 2007; COZZI et al., 2013). Assim como descrito por Cozzi et al. (2013), o aumento de alguns desses AA (oriundos da proteína de mobilização tecido muscular) no verão, levaria a um aumento dos níveis de creatinina e CK após algumas semanas, como observado no presente estudo.

Figura 3 A Variação da concentração de Albumina (ALB) (mg/dL) no soro de vacas de alta (AP) e média (MP) produção, no inverno (I) e no verão (V)

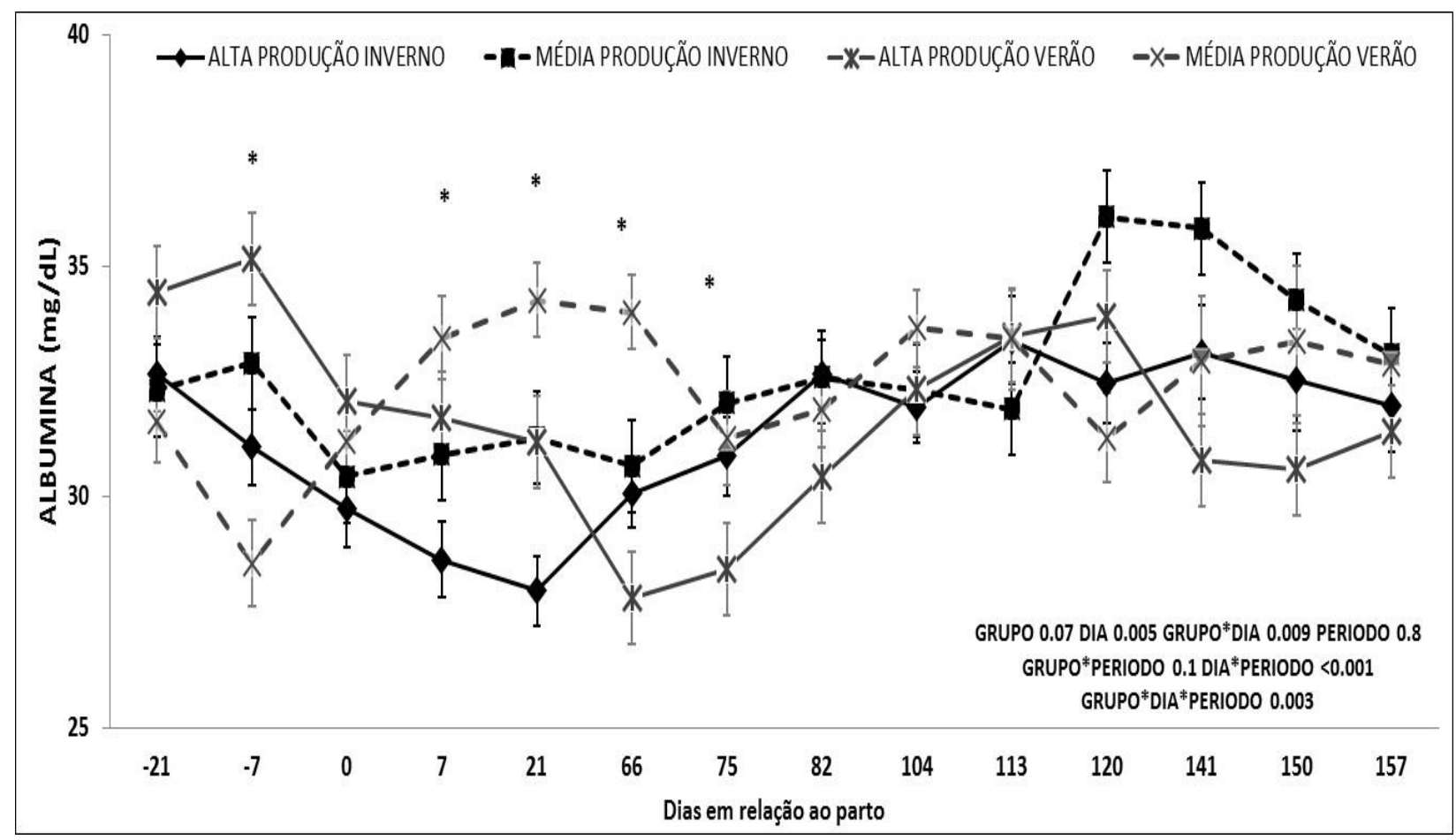

$* \mathrm{P}<0,05, * * \mathrm{P}=0,001, * * * \mathrm{P}<0,001$ para as comparações no período de transição e início da lactação. $\mathrm{AP}^{1}$ (>45.9 kg no pico de produção - média 54.6 \pm 5.3 ); $\mathrm{MP}^{2}$ (entre 32 e 45,8 kg no pico - média $36.7 \pm 4.8$ ) 
Figura 3B - Variação da concentração de Albumina (ALB) (mg/dL) no soro das vacas leiteiras prenhes à primeira IATF ou vazias aos 150 DEL no inverno (I) e no verão $(\mathrm{V})$

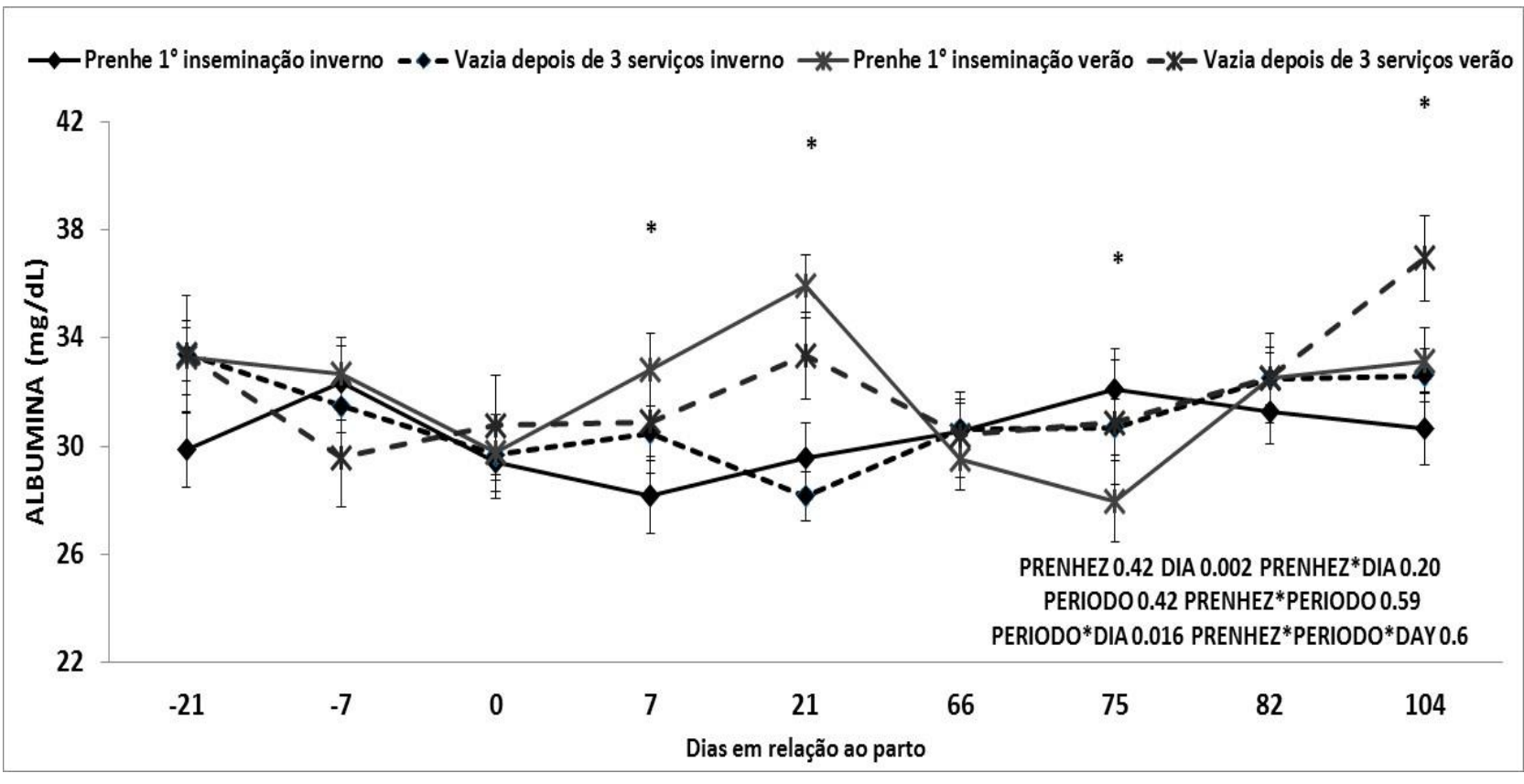

$* \mathrm{P}<0,05, * * \mathrm{P}=0,001, * * * \mathrm{P}<0,001$ para as comparações no período de transição e início da lactação. $\mathrm{AP}^{1}$

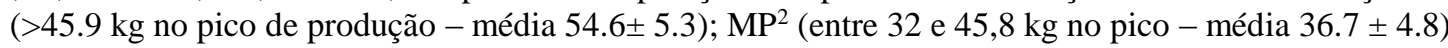

Figura 4A Variação da concentração de globulinas (GLOB) (mg/dL) no soro de vacas de alta (AP) e média (MP) produção, no inverno (I) e no verão $(\mathrm{V})$

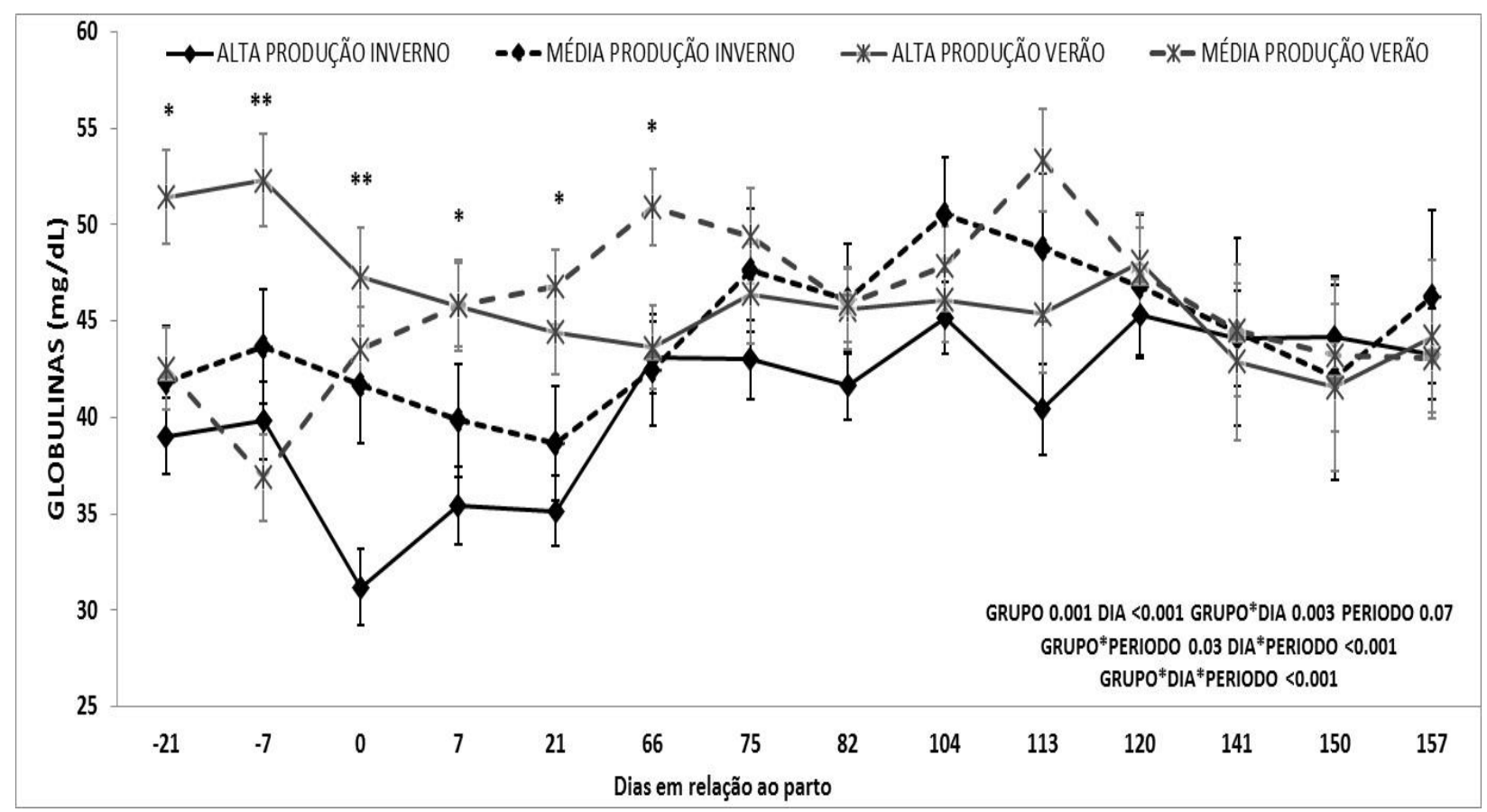

* $\mathrm{P}<0,05, * * \mathrm{P}=0,001, * * * \mathrm{P}<0,001$ para as comparações no período de transição e início da lactação. $\mathrm{AP}^{1}$ (>45.9 kg no pico de produção - média 54.6士 5.3); $\mathrm{MP}^{2}$ (entre 32 e 45,8 kg no pico - média $36.7 \pm 4.8$ ) 
Figura 4B - Variação da concentração de globulinas (GLOB) (mg/dL) no soro das vacas leiteiras prenhes à primeira IATF ou vazias aos 150 DEL no inverno (I) e no verão (V)

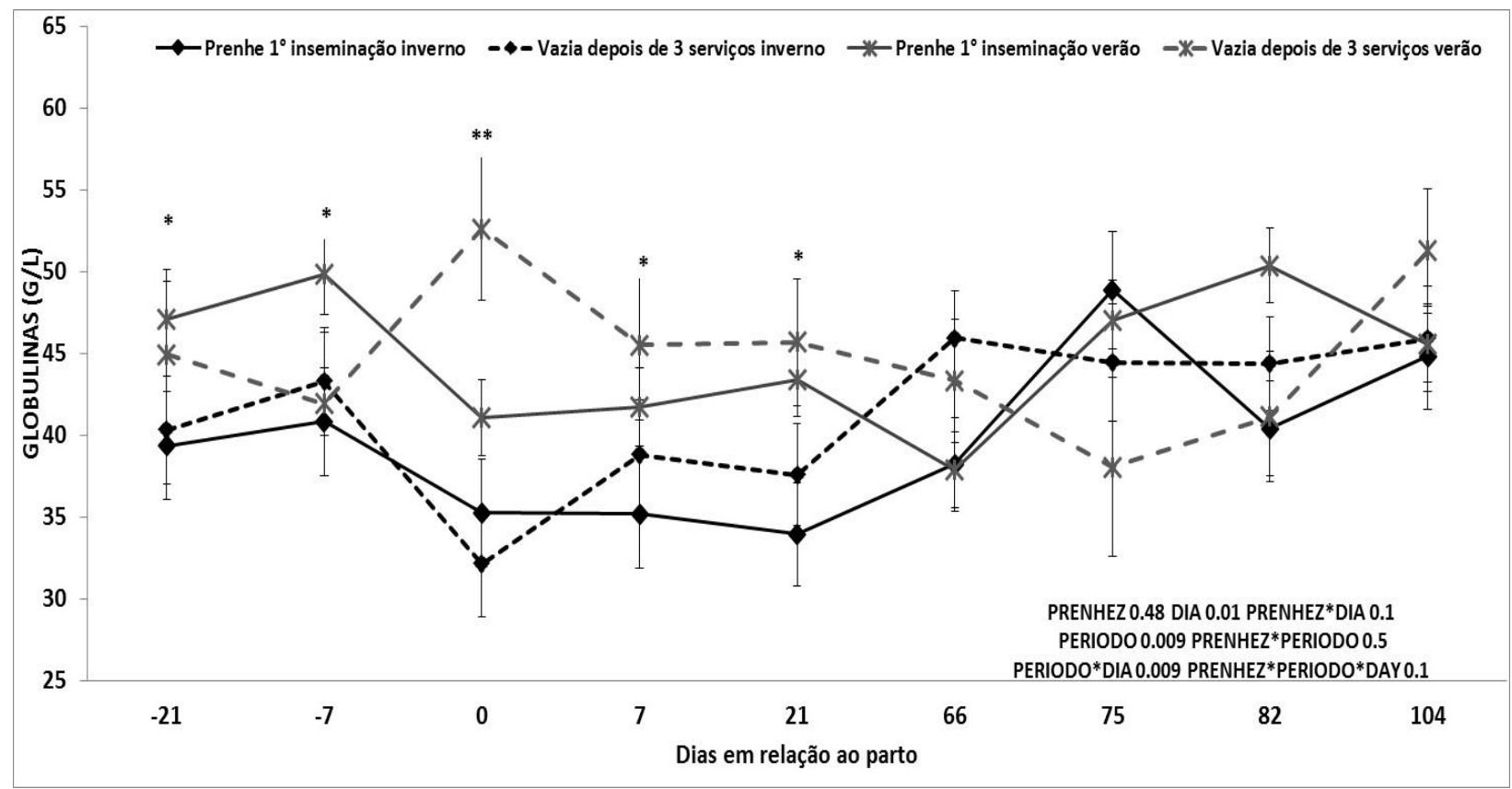

* $\mathrm{P}<0,05, * * \mathrm{P}=0,001, * * * \mathrm{P}<0,001$ para as comparações no período de transição e início da lactação. $\mathrm{AP}^{1}$

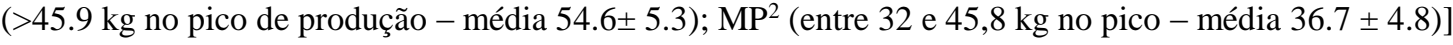

Figura 5A - Variação da relação Albumina:globulinas (AGR) no soro de vacas de alta (AP) e média (MP) produção, no inverno (I) e no verão (V)

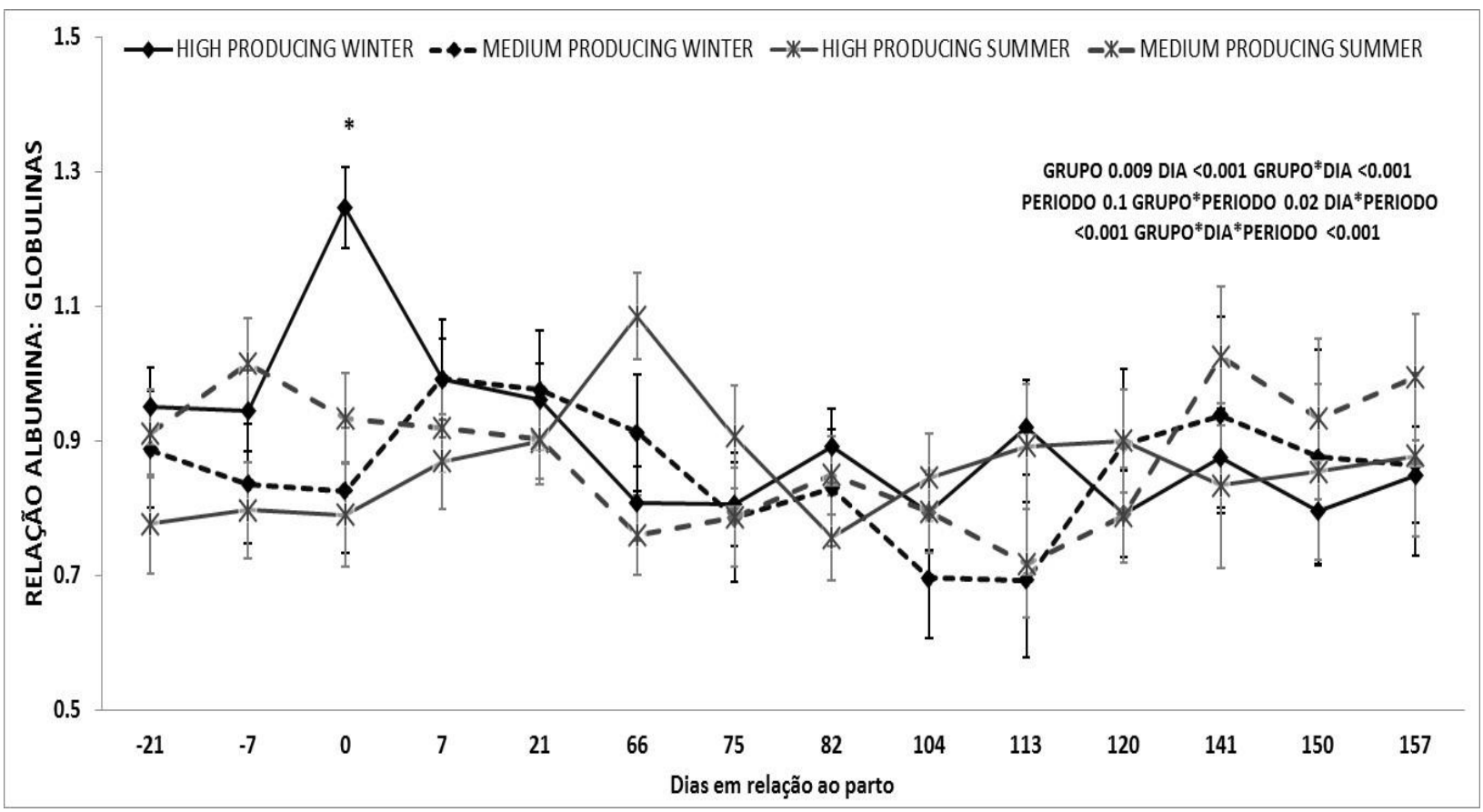

$* \mathrm{P}<0,05, * * \mathrm{P}=0,001, * * * \mathrm{P}<0,001$ para as comparações no período de transição e início da lactação. AP (>45.9 kg no pico de produção - média 54.6士 5.3); $\mathrm{MP}^{2}$ (entre 32 e 45,8 kg no pico - média $36.7 \pm 4.8$ ) 
Figura 5B - Variação da relação Albumina:globulinas (AGR) no soro das vacas leiteiras prenhes à primeira IATF ou vazias aos 150 DEL no inverno (I) e no verão (V) (entre 32 e 45,8 kg no pico - média $36.7 \pm 4.8$ )

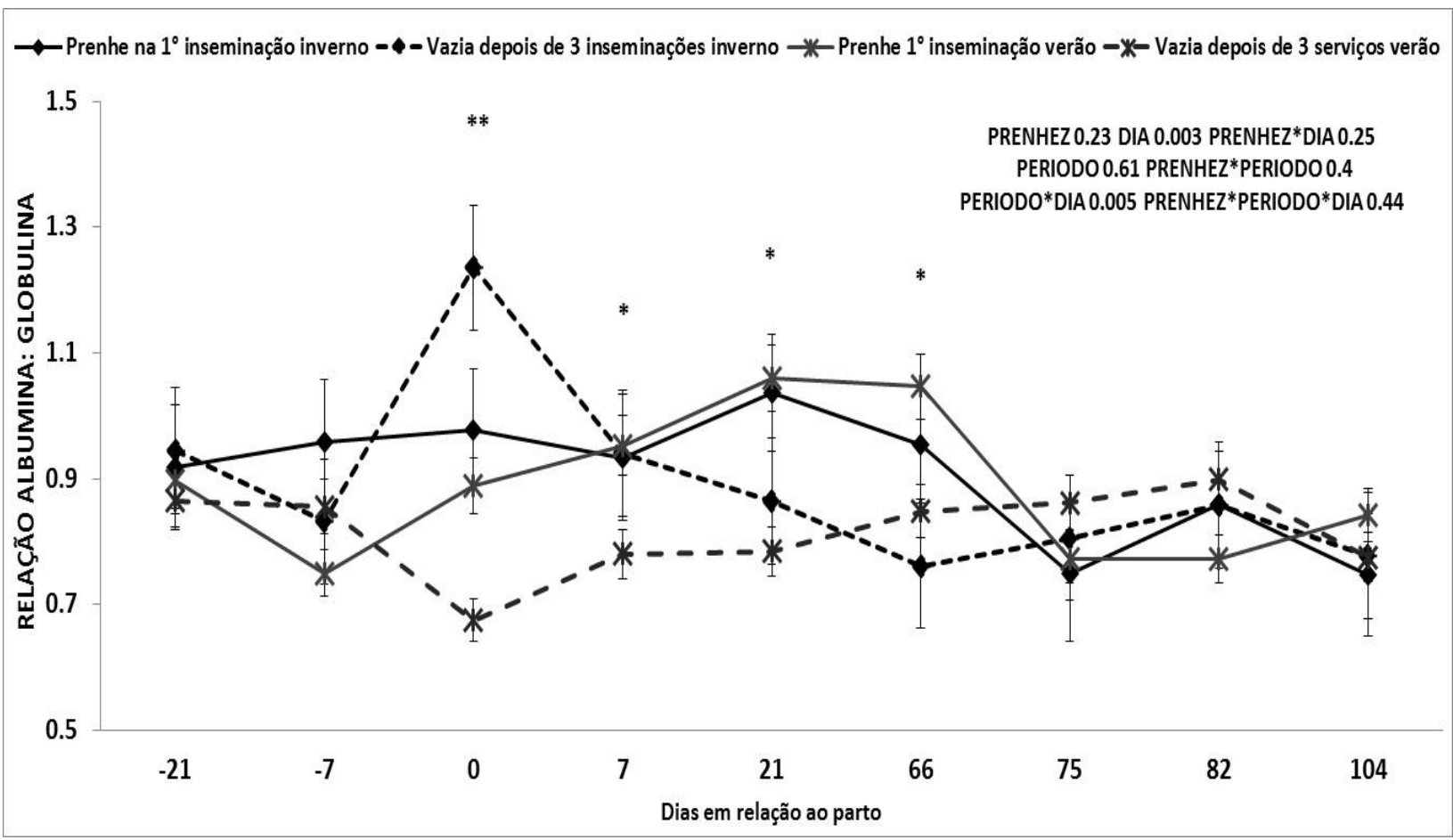

* $\mathrm{P}<0,05, * * \mathrm{P}=0,001, * * * \mathrm{P}<0,001$ para as comparações no período de transição e início da lactação. AP

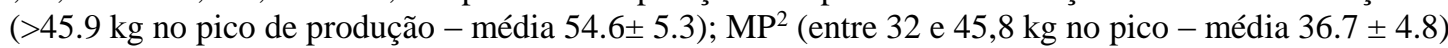

3.5.2 Enzimas hepáticas e superóxido dismutase

Não foi observado nenhum efeito $(P>0,05)$ ou interação $(P>0,05)$ nas variações e nos valores de GGT, AST, CK e SOD em vacas prenhes ao primeiro serviço ou vazias a inseminação aos 150 DEL.

Não houve efeito de grupo $(\mathrm{P}=0,43)$, dia $(\mathrm{P}=0,12)$ ou estação $(\mathrm{P}=0,36)$ e também não houve nenhuma interação (grupo $\mathrm{x}$ dias $\mathrm{P}=0,19$; grupo $\mathrm{x}$ estação $(\mathrm{P}=0,78)$; dias $\mathrm{x}$ temporada $(\mathrm{P}=0,5)$, e grupo $\mathrm{x}$ dia $\mathrm{x}$ estação $(\mathrm{P}=0,3)$ entre esses fatores sobre os níveis de GGT durante o período de transição e início da lactação. Não houve efeito de grupo $(\mathrm{P}=0,12)$ para a atividade de AST. As interações, grupo x estação $(P=0,52)$; dias x estação $(P=0,32)$ e grupo $\mathrm{x}$ dia $\mathrm{x}$ estação $(\mathrm{P}=0,32)$ também não foram significativas. Houve uma tendência de interação entre grupo x dias $(\mathrm{P}=0.07)$ para AST. As vacas do período de inverno apresentaram uma atividade mais elevada dessa enzima durante o período pré- parto. 
Houve efeito de grupo $(\mathrm{P}=0,002)$ e interação entre grupo $\mathrm{x}$ dia $\mathrm{x}$ estação $(\mathrm{P}=0,004)$ para CK. Não houve efeito do dia $(P=0,12)$, estação $(P=0,43)$, dia $x$ estação $(P=0,37)$ para CK (Figura 6). Houve uma tendência de efeito de grupo $\mathrm{x}$ tempo $(\mathrm{P}=0,06)$ para essa variável.

Esse aumento de CK, provavelmente está ligado ao aumento na produção leiteira no pico de lactação e também por ter ocorrido um aumento no grau de claudicação dos animais de todos os grupos experimentais. As comparações dos resultados obtidos para a atividade enzimática sérica da CK evidenciaram que as mudanças nos padrões dessa enzima ocorrem em fases de maior exigência energética e que, portanto, podem sobrecarregar atividade hepática até mesmo em um período onde os animais já regularam o CMS. Esses resultados em concordância com Tradati et al. (1982) e Souza (2005).

Provavelmente, esse aumento da CK durante o pico de lactação está relacionado tanto ao papel importante que esta enzima tem na rápida regeneração dos ATP em células de tecidos onde tais exigências são altas, como fígado, glândula mamária e tecido muscular (maior exigência em vacas com claudicação) e também como uma tentativa do organismo melhorar a atividade de células de defesa (durante períodos de supressão imune), como ocorre com as vacas no inicio do período de lactação (LACETERA et al., 2005).

$\mathrm{O}$ aumento da CK pode derivar do aumento do esforço físico nas vacas com algum grau de claudicação. Alguns estudos em humanos com hipotiroidismo mostram que em alguns períodos, onde estes pacientes têm uma maior supressão imune, associados a algum tipo de lesão ou também de maior exigência muscular, ocorre um aumento dos níveis de CK (HEKIMSOY et al.; 2005). Os autores do estudo citado até sugeriram que existe uma alta correlação entre os níveis séricos de CK e os níveis de TSH em pacientes com hipotireiodismo subclínico, e que esta correlação seria um mecanismo compensatório de regulação dos teores dessa enzima, feito pelas células musculares em resposta a níveis subótimos de hormônios da tiróide.

Alguns estudos também evidenciaram que durante períodos de estresse térmico, ocorre um aumento do catabolismo de AA para a energia (RONCHI et al., 1999; ABENI et al., 2007; COZZI et al., 2013), conseqüentemente levaria a um aumento dos níveis de creatinina e CK no plasma após algumas semanas, que foi observado no presente estudo durante o pico de lactação.

No estudo de Cozzi et al. (2013) foi verificado uma variação de $20 \%$ nos valores de CK entre rebanhos leiteiros, sendo os principais fatores fixos nas mudanças do intervalos de confiança desta enzima, a paridade, a fase de lactação e a estação do ano. Não há indicações que foram encontradas na literatura para explicar das mudanças desta enzima, mas, as 
concentrações mais elevadas de fósforo em vacas jovens já foram relatados por O'Dell e McAdam (1982) como essenciais para uma maior atividade do hormônio do crescimento. Quando isso ocorre, a absorção e a reabsorção de fosfato intestinal parecem ser mais intensas, conseqüentemente, a atividade dessa enzima (MEYER; HARVEY, 2004).

Entretanto, os mecanismos ainda não estão bem elucidados. Portanto, claramente, mais estudos são necessários para determinar a razão para a elevação da CK e sua relação com os problemas metabólicos e com a fertilidade de vacas leiteiras.

Figura 6- Variação da concentração de creatina quinase (CK) (U/L) no soro de vacas de alta (AP) e média (MP) produção, no inverno (I) e no verão (V)

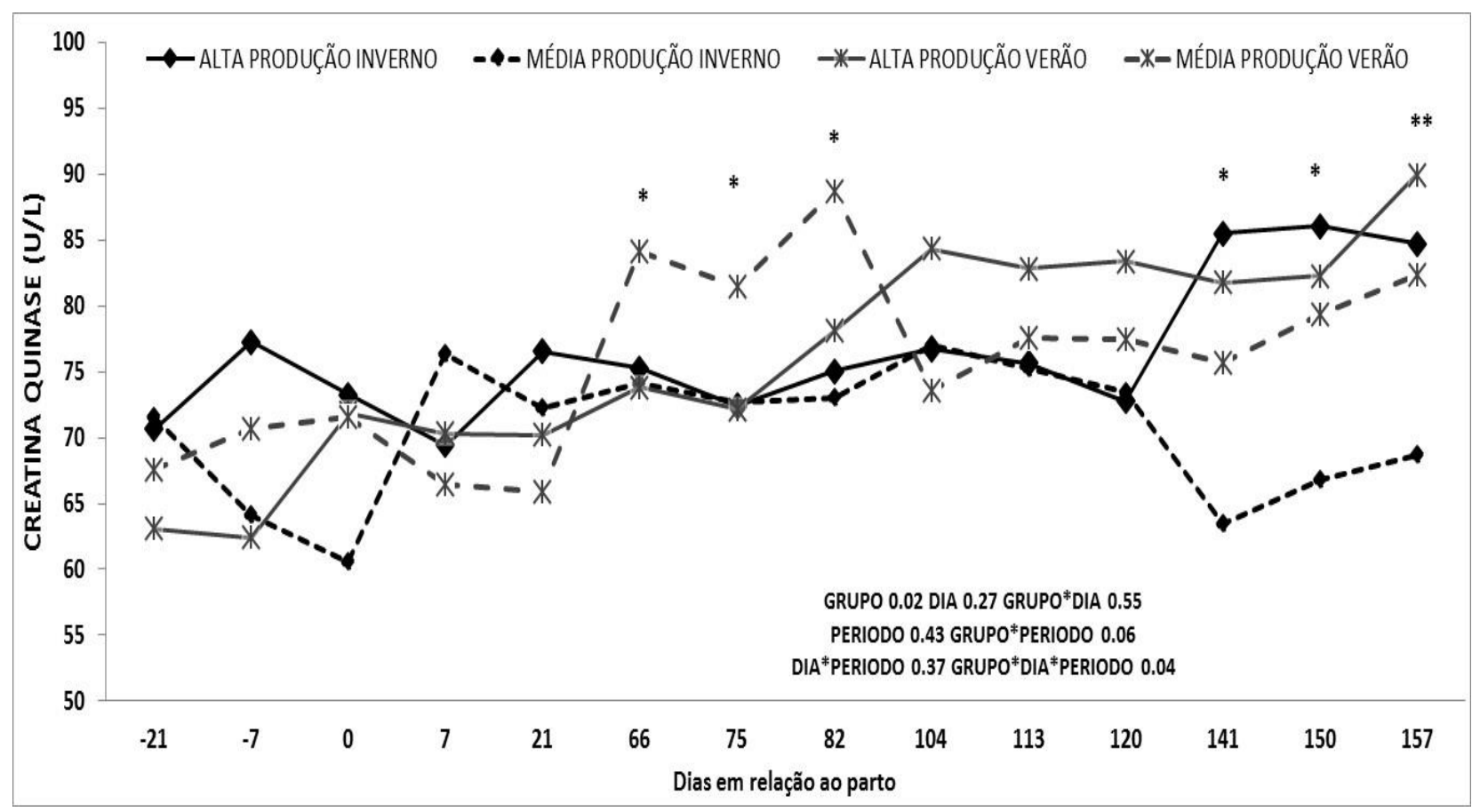

* $\mathrm{P}<0,05, * * \mathrm{P}=0,001, * * * \mathrm{P}<0,001$ para as comparações no período de transição e início da lactação. $\mathrm{AP}^{1}$

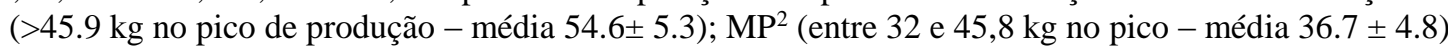

Houve efeito de grupo $(\mathrm{P}<0,001)$, dia $(\mathrm{P}=0,001)$ e estação $(\mathrm{P}<0.001)$ para a atividade da enzima SOD. Houve também interação entre grupo x estação $(\mathrm{P}<0,001)$, dia x estação e uma tendência do efeito entre grupo x dia x estação $(P=0,08)$, conforme figura 7 . Não houve interação entre grupo x dia $(\mathrm{P}=0,29)$.

As vacas do grupo de alta produção de ambos os períodos (API e APV), tiveram valores de SOD mais elevados do que as vacas de média produção (MPI e MPV), embora não tenham mantido um padrão de variação semelhante nos dois períodos, como ocorreu para as vacas de média produção. A atividade da enzima SOD foi maior nas vacas do grupo AP a partir de 7 
dias antes do parto até os 104 dias em lactação, que está diretamente relacionado a maior capacidade de defesa aos radicais livres e que possivelmente reflete em uma adaptação mais rápida desses animais aos eventos metabólicos da lactação.

No estudo de Bernabucci et al. (2005), monitorando as mudanças na condição metabólica e na condição de estresse oxidativo de vacas leiteiras de durante o período de transição no inverno e no verão também verificaram que uma semana antes do parto, as vacas apresentaram um aumento de SOD, sem alterações no numero de eritrócitos. Entretanto, após o parto, as vacas de ambos períodos mostraram uma redução de SOD, e um aumento de espécies reativas de oxigênio no plasma. Eles verificaram que tanto as vacas com maior ECC no início do período de transição tiveram menores teores de SOD no inicio da lactação, o que foi diferente dos resultados encontrados no presente estudo. As vacas de alta produção leiteira tiveram melhor condição corporal no pré-parto e também uma menor variação do ECC no inicio do período pós-parto, juntamente com níveis mais elevados de SOD durante todo inicio de lactação.

Portanto, parece que a mudança da condição corporal e não a somente o ECC no inicio do período de transição é o fator importante a ser considerado na explicação das variações na atividade dessa enzima em vacas leiteiras e isso está de acordo com o NRC (2001) e com os estudo de Grum et al. (1996), que evidencia que vacas leiteiras com maior condição corporal (acima de 4,0 no pré-parto) normalmente tem uma redução mais acentuada do CMS (>30\%) durante o período de transição, conseqüentemente, aumentando a mobilização de reservas corporais, e a formação de espécies reativas de oxigênio. Essa hipótese está de acordo com os achados de Hayirili et al. (1999); Cope et al. (2009) e Dobbelaar et al. (2010), e também com os achados de Bernabucci et al. (2005). Corroborando com essa hipótese, alguns estudos já mostraram aumentos na incidência de doenças no peri parto devido a ao aumento da condição de estresse oxidativo ocasionada pela deficiência de $\mathrm{Zn}$ em vacas leiteiras (SIES, 1991; MILLER et al., 1993; RONCHI et al., 2000).

Os teores de SOD foram menores durante as primeiras semanas de lactação em ambos os grupos período do verão, que pode estar relacionado tanto a uma redução mais acentuada no CMS durante este período, como também aos menores teores de cobre e zinco na dieta desses animais (Tabela 4). Normalmente, nos ruminantes, no máximo 3\% do Cu consumido é absorvido, sendo que deste, $90 \%$ é depositado principalmente no fígado (MCDOWELL, 2003). Do cobre plasmático, aproximadamente $90 \%$ ocorre na forma de ceruloplasmina, que é uma proteína de fase aguda (SAUT, 2004), provavelmente, sendo este outro fator que explicaria a baixa atividade de SOD no verão. 
Ainda, esses baixos teores de SOD no inicio do período pós parto, podem estar ligados aos elevados teores de AGNE e BHBA para as vacas de alta e média produção no verão $(0,52$

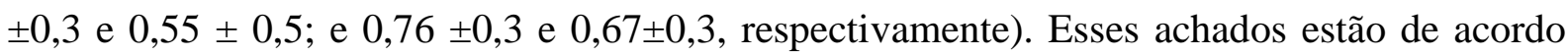
com o estudo de Bernabucci et al. (2005) que também verificaram que vacas com maior teor plasmático de BHBA e NEFA também tinham maior ROM e TBARS e baixos níveis de SOD e outros anti-oxidantes.

Os possíveis efeitos dos AGNE e BHBA sobre a atividade de SOD estariam ligados a possíveis mudanças no polimorfismo de nucleotídeo único (SNP) no gene que codifica a SOD1, tais como o SNP A35C e G2809A, que é o que normalmente ocorre em humanos diabéticos (SUBAPRIYA et al., 2002; BEEVI et al., 2004; CEBRIAN et al., 2006; EIDE, 2006; DIMAYUGA et al., 2007; FLEKAC et al., 2008; TAYSI et al., 2008; SLIWINSKI et al., 2009; YOKOE et al., 2009; BRESSAN, 2010). Levando em consideração que no início do período de lactação as vacas leiteiras passam por períodos de resistência a insulina (ZACHUT et al., 2013), provavelmente esse conceito dos polimorfismo se aplique atividade de SOD em vacas peri-parturientes. Apesar de serem restritas informações a respeito da consequiência funcional desses polimorfismos, mesmo em humanos, verificou-se que o SNP SOD1 A35C resultou em redução da atividade da enzima codificada em indivíduos saudáveis como e diabéticos (FLEKAC et al., 2008). O SNP SOD1 G2809A também é outra fração do gene que tem sido descrita como uma das áreas principais de polimorfismo, por sua vez, também diminui a atividade dessa enzima, entretanto, foi avaliada apenas em pacientes com câncer de mama (CEBRIAN et al., 2006; UDLER et al., 2007; BRESSAN, 2010). Nenhum estudo dando essa abordagem relacionada a possíveis alterações no polimorfismo da SOD foi realizado em vacas leiteiras até o presente.

Partindo do pressuposto de que o estado oxidativo de vacas leiteira pode ser mais acentuado pelo estresse térmico, uma das hipóteses do presente estudo foi a de que a produção leiteira e a estação do ano iriam diminuir a atividade de SOD durante o período de transição e inicio de lactação. No entanto, a hipótese se confirmou somente no que diz respeito a diminuição dessa enzima no período de transição, contrariando os resultados de Calamari et al. (1999), que também observaram efeitos negativos do estresse térmico sobre alguns marcadores plasmáticos de estresse oxidativo em vacas no terço médio de lactação.

A hipótese de que a atividade de SOD seria menor no verão também para as vacas de média produção, também não foi confirmada, pois não houve diferenças entre esses dois grupos. No presente estudo, verificou-se que os marcadores plasmáticos do estado oxidativo em vacas no verão não diferem daqueles observados no inverno, mas que a produção leiteira 
altera os padrões de atividade de algumas enzimas. Estudos anteriores sobre estresse térmico e estado oxidativo de vacas leiteiras, foram realizados apenas em vacas no terço médio de lactação (HARMON et al., 1997; TROUT et al., 1998; CALAMARI et al., 1999). Alguns estudos desenvolvidos no inicio de lactação, voltados a mensurar as condição de estresse oxidativo em vacas leiteiras (RONCHI et al., 2000) abordaram apenas aumentos na incidência de doenças puerperais e doenças metabólicas, mas, nenhum enfoque foi dado a fertilidade das vacas.

No presente estudo, não foi observado nenhum efeito $(\mathrm{P}>0,05)$ de grupo, dia ou estação bem como interações $(\mathrm{P}>0,05)$ entre estes fatores nas variações dos níveis de SOD em vacas prenhes no primeiro serviço ou vazias aos 150 DEL no inverno e no verão.

Nos estudos de Maturana Filho et al. (2012a,b) com vacas e novilhas nelores durante a estação de monta nos meses quentes do ano, foi verificado tanto em vacas primiparas como em multíparas que a maior atividade de SOD no dia da inseminação artificial em tempo fixo, se correlacionou tanto com o aumento da taxa de prenhez (baixa $\mathrm{SOD}=55,8 \%$, sendo $\mathrm{n}=222$ VS alta $\mathrm{SOD}=67,1 \%$, sendo $\mathrm{n}=110)$ como da menor taxa de perda embrionária (10 vs 3,5\%, respectivamente). Os valores médios de SOD nesses estudos citados foram de $2592 \pm 79$ para as vacas de alta SOD. Estes valores foram os limites inferiores da atividade dessa enzima nas vacas leiteiras, independente da estação do ano.

Embora eritrócitos sejam um modelo adequado e sensível para estudar o estado oxidativo em vacas leiteiras durante o período de transição (BERNABUCCI et al., 2005), a avaliação do efeito do estresse térmico não foi suficiente para elucidar o efeito do estresse oxidativo sobre a fertilidade das vacas no presente estudo, por dois motivos principais: 1) Baixa variação nos parâmetros de variáveis ligadas ao hemograma, como: a) contagem de eritrócitos independente do grupo, dia ou período; b) Baixa variação nas concentração de hemoglobina nas vacas APV, MPI e MPV; 2) O estresse térmico ter sido moderado durante o período de transição, pois todas as vacas ficavam no galpão de ventilação cruzada.

Em vacas leiteiras, a utilização somente da SOD como marcador de estresse oxidativo não dá informações suficientes para chegar a definitiva conclusões dos impactos sobre a fertilidade, mas é um modelo importante para estudar diferenças produtivas de vacas em resposta ao estresse por calor. 
Figura 7 - Variação da concentração de Superóxido dismutase (SOD)/ g de hemoglobina no soro de vacas de alta (AP) e média (MP) produção, no inverno (I) e no verão (V)

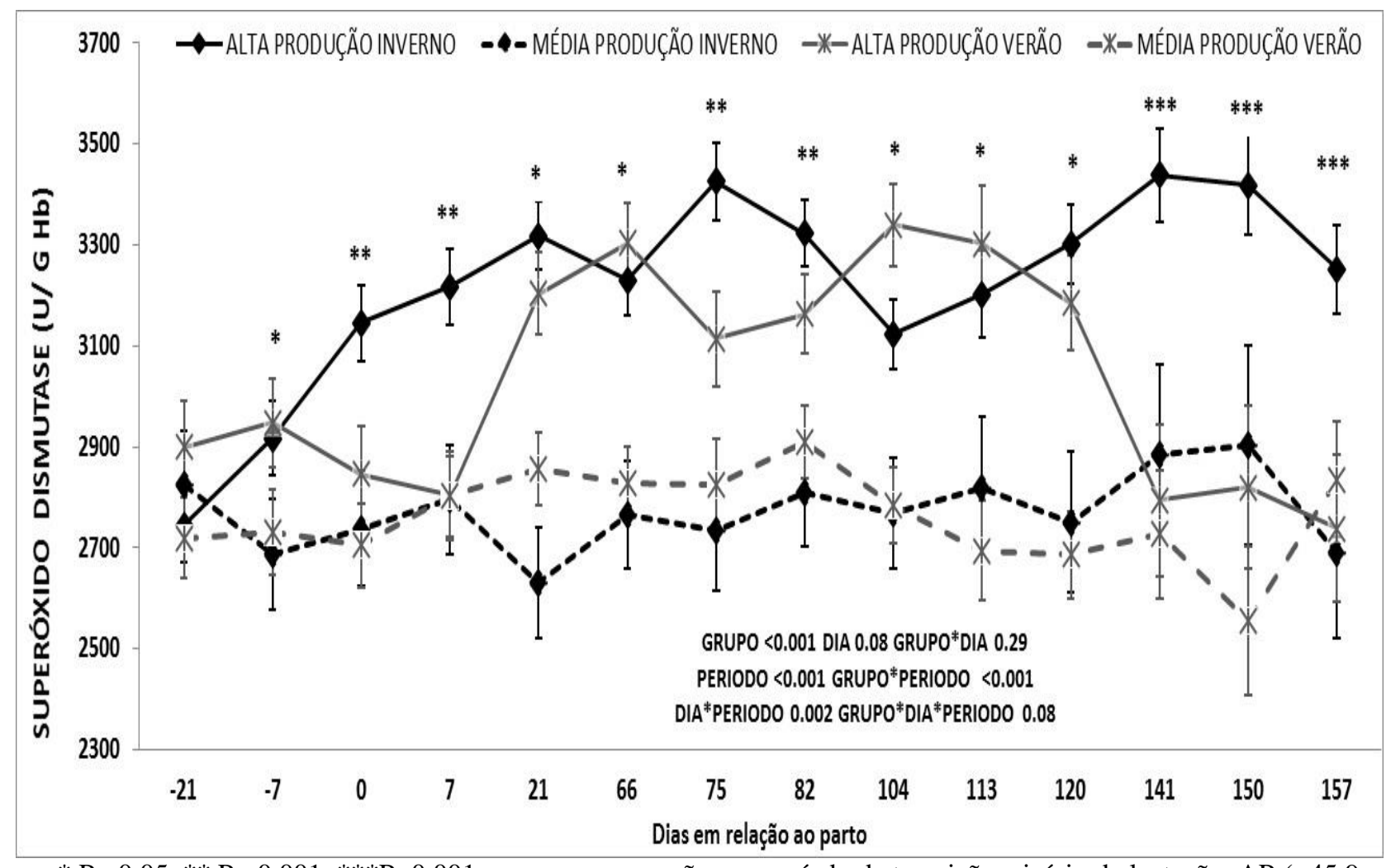

$* \mathrm{P}<0,05, * * \mathrm{P}=0,001, * * * \mathrm{P}<0,001$ para as comparações no período de transição e início da lactação. AP (>45.9

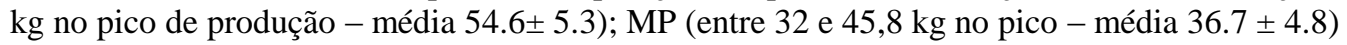

\subsubsection{Metabolismo energético: Glicose e lipídios}

Houve efeito de grupo $(\mathrm{P}<0,001)$, dia $(\mathrm{P}<0,05)$ e interações entre grupo $\mathrm{x}$ dia $(\mathrm{P}=0,004)$ e dia x período $(\mathrm{P}<0,05)$ para as concentrações de glicose. Houve também interação entre grupo $\mathrm{x}$ estação $(\mathrm{P}<0,0001)$, dia $\mathrm{x}$ estação e uma tendência do efeito entre grupo $\mathrm{x}$ dia $\mathrm{x}$ estação $(P=0,08)$, conforme figura $8 \mathrm{~A}$. Não houve efeito de estação $(\mathrm{P}=0.20)$ bem como entre grupo x estação $(\mathrm{P}=0,6)$. As Vacas do grupo API e APS tiveram níveis mais baixos deste metabolito em comparação com os grupos MPI e MPV. Esta condição, com altas concentrações de glicose, associados a níveis mais elevados de TC e TG são indicativos de um quadro de resistência a insulina como um dos fatores determinantes para a produtividade durante o pico de lactação (GONZÁLES, 2007; ZACHUT et al., 2013).

Houve somente efeito de grupo de prenhez $(\mathrm{P}=0,04)$ e período $(\mathrm{P}=0,02)$ para as concentrações de glicose em vacas prenhes no primeiro serviço ou vazias aos 150 DEL no 
inverno e no verão (Figura 8B). As vacas vazias de ambos os períodos apresentaram teores mais elevados após o parto até os 100 dias de lactação e com maior variação quando comparado as vacas prenhez no primeiro serviço.

No estudo de Souza (2005), avaliando a função hepática e o lipidograma no período puerperal, em vacas holandesas que tiveram ou não algum distúrbio reprodutivo, não foi encontrada nenhuma diferença de grupo $(\mathrm{P}>0,05)$ ou efeito de dia $(\mathrm{P}>0,05)$ nos valores de glicose durante o pré parto e inicio de lactação, ao contrário dos resultados do presente estudo, que também corroboram com Maturana Filho (2009); Gandra (2012) e Garverick (2004). Provavelmente o resultado está ligado ao menor potencial leiteiro dos animais utilizados no

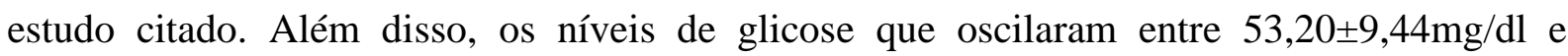
$58,76 \pm 9,86 \mathrm{mg} / \mathrm{dl}$, relatados no estudo de Souza (2005) são mais inferiores do que os valores médios dos estudos de Maturana Filho (2009); Gandra (2012) e Garverick (2004) no mesmo período de avaliação.

Okawa e Oetzel (2006), estudando o efeito do balanço energético no desenvolvimento de esteatose hepática e na resistência à insulina, verificaram que os teores de glicose não variaram em vacas leiteiras não lactantes (que foram submetidas a períodos de jejum), entretanto, elas tinham maior teor de triglicerídeos no fígado $(49,4 \mathrm{vs} 16,2 \mathrm{mg} / \mathrm{g})$, concentrações de AGNE (1,24 vs 0,21 mmol / L) e as concentrações de insulina no plasma foram diminuídas (6,3 vs 14,1 U / mL). Quando as vacas foram estimuladas por insulina, houve uma redução média de glicose de 24,9 vs $48,6 \%$ em vacas submetidas ou não a períodos de jejum, respectivamente, indicando reduzida a resposta de insulina. A Resposta à insulina foi negativamente correlacionada com NEFA no plasma e triglicerídeos no fígado. Esses resultados de Okawa e Oetzel (2006) ajudam a confirmar e a sustentar alguns dos achados do presente experimento, pois, as vacas que tiveram maiores concentrações de glicose plasmática, foram aquelas de menor produção leiteira e que também tiveram as maiores concentrações de NEFA no inicio do período pós parto.

Alguns estudos não mostraram diferenças nos teores de glicose no período de transição (SOUZA, 2005; MATURANA FILHO, 2009; GANDRA, 2012; GARVERICK, 2004), entretanto, algumas diferenças importantes caracterizam e direcionam os valores e os efeitos encontrados sobre os teores de glicose no presente estudo. Nos estudo citados, excluindo os de Maturana Filho (2009) e Gandra (2012), que tiveram valores semelhantes de glicose ao do presente estudo, nos demais, os teores plasmáticos desse metabólito foram inferiores tanto no pré, como no pós-parto, bem como os teores de AGNE e BHBA foram mais elevados. 
Em alguns estudos, foi verificado que vacas que apresentam melhor CMS durante o período de transição e menor AGNE e BHBA, normalmente, a variação e os teores de glicose plasmática foram maiores no inicio do pós parto, assim como no presente estudo (OIKAWA et al., 1997; BERTICS et al., 1992; MOHAMED et al., 2004;).

Finalizando a avaliação dos teores de glicose, usando o modelo de prenhez, foram observadas diferenças entre as vacas prenhes no primeiro serviço (menores teores) e aquelas vazias depois da terceira inseminação. Esse resultado pode ser atribuído a maior produção leiteira e, portanto, maior desprendimento da glicose para a síntese de lactose, uma vez que a taxa de prenhez no primeiro serviço, não foi diferente entre os grupos de produção, mas o teor de lactose. Os resultados do presente estudo são diferentes dos resultados de Santos (2004), que encontraram maiores teores, mas corroboram com os resultados encontrados por Garverick (2004). No estudo de Souza (2005), também houve uma oscilação dos teores plasmáticos de glicose durante a transição entre vacas que emprenham entre o primeiro e quinto serviço (entre $56,22 \pm 5,69 \mathrm{mg} / \mathrm{dl}$ e $60,70 \pm 6,32 \mathrm{mg} / \mathrm{dl}$ ), entretanto, não houve diferença estatística, que pode ser atribuída, ao numero de grupos de prenhez e por ter apenas analisado esses dados por teste de média e não regressão logística.

Figura 8a - Variação da concentração de glicose (GLI) (mg/dL) no soro de vacas de alta (AP) e média (MP) produção, no inverno (I) e no verão (V)

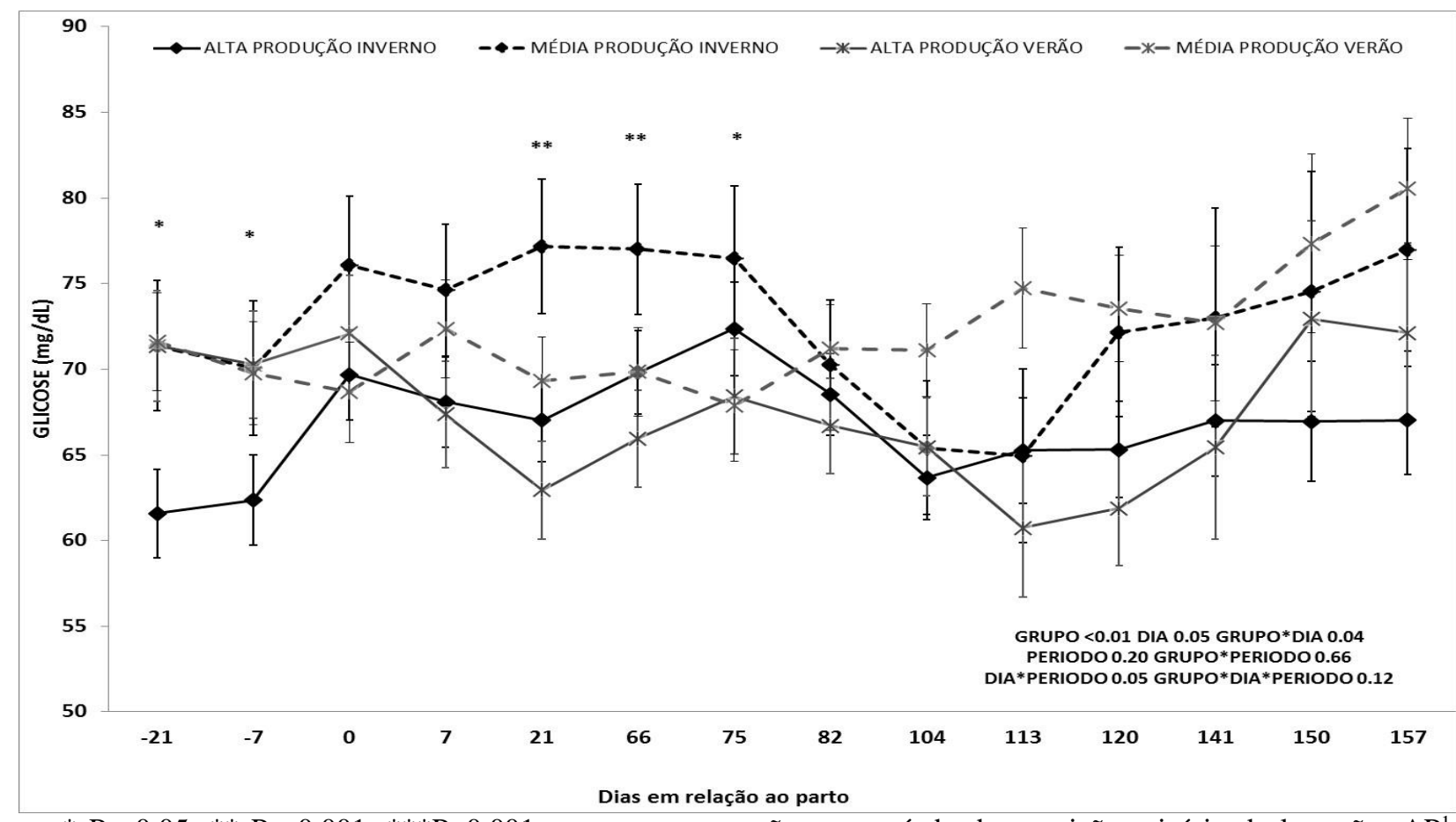

* $\mathrm{P}<0,05, * * \mathrm{P}=0,001$, ***P<0,001 para as comparações no período de transição e início da lactação. AP

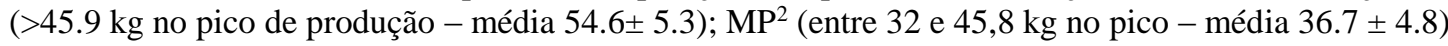


Figura 8B - Variação da concentração de glicose (GLI) $(\mathrm{mg} / \mathrm{dL})$ no soro das vacas leiteiras prenhes à primeira IATF ou vazias aos 150 DEL no inverno (I) e no verão (V)

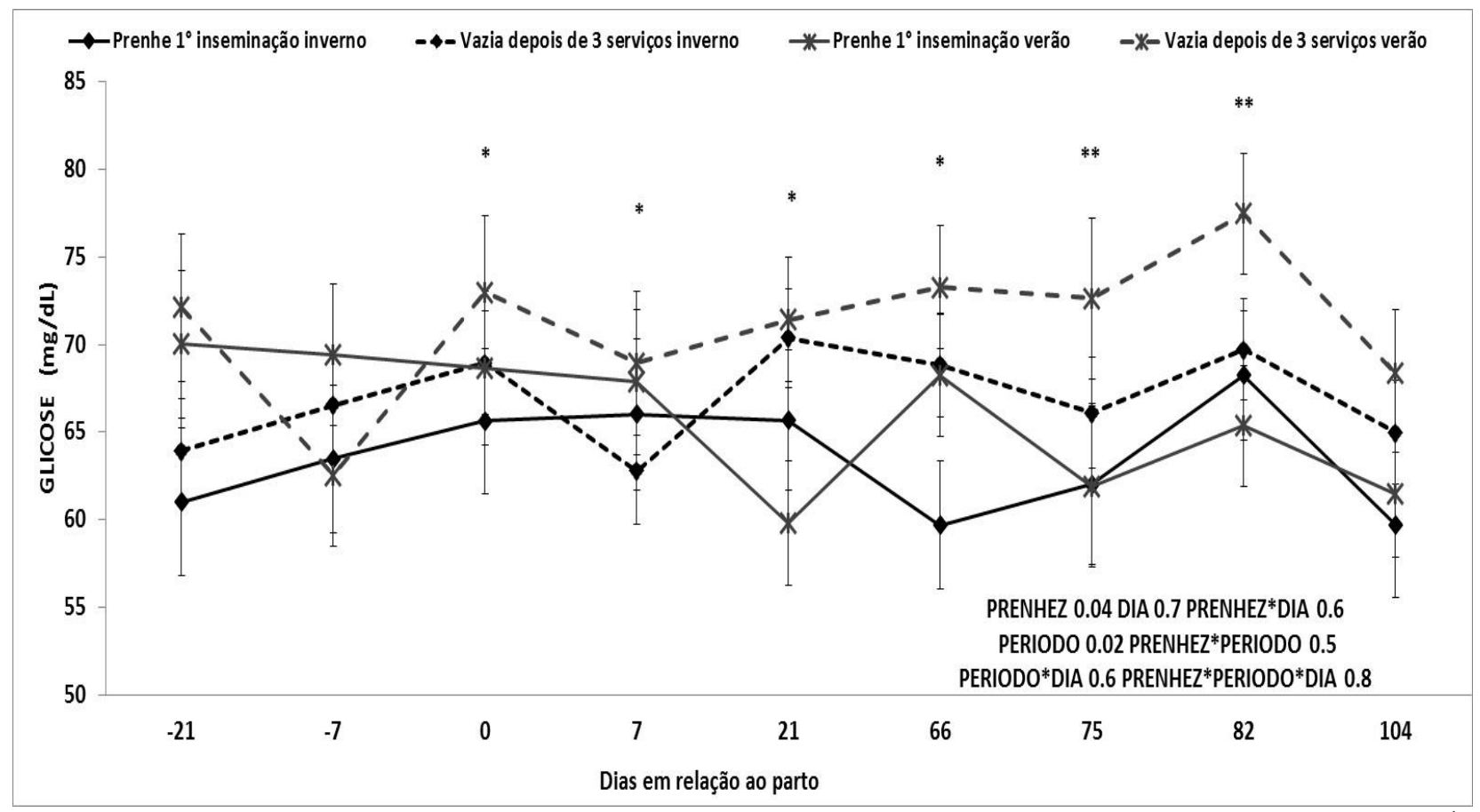

$* \mathrm{P}<0,05, * * \mathrm{P}=0,001, * * * \mathrm{P}<0,001$ para as comparações no período de transição e início da lactação. AP (>45.9 kg no pico de produção - média 54.6士 5.3); $\mathrm{MP}^{2}$ (entre 32 e 45,8 kg no pico - média $36.7 \pm 4.8$ )

Não foi observada nenhuma diferença $(\mathrm{P}>0,05)$ nas variações e nos valores de $\mathrm{CT}$, TG, VLDL, LDL, relação LDL: CT e na relação LDL: HDL em vacas prenhez ao primeiro serviço ou vazia aos 150 dias.

As diferenças no perfil lipídico foram observadas somente no modelo animal de grupo de produção nas estações do ano. Foi observado um efeito de grupo de produção $(\mathrm{P}<0,001)$ e interação entre dia x estação para as concentrações de colesterol total. Houve uma tendência de efeito de dias $(\mathrm{P}=0.1)$ e não houve efeito de estação $(\mathrm{P}=0.2)$, conforme figura 9. Semelhantemente ao colesterol total, foi observado um efeito de grupo de produção $(\mathrm{P}=0,004)$, dia $(\mathrm{P}=0,01)$, período $(\mathrm{P}=0,01)$ e interação entre grupo $\mathrm{x}$ dia $(\mathrm{P}=0,03)$ e grupo $\mathrm{x}$ dia x período $(\mathrm{P}=0,09)$ para as concentrações de triacilglicerol, conforme figura 10.

Houve efeito de grupo de produção $(\mathrm{P}<0,05)$, dia $(\mathrm{P}=0,03)$, e interação entre grupo $\mathrm{x}$ dia $\mathrm{x}$ período $(\mathrm{P}=0,003)$ para as concentrações de $\mathrm{HDL}$, conforme figura 11A. Houve uma interação entre período x dia $(\mathrm{P}<0,05)$ para os teores desse metabólito quando usado o modelo animal de grupos de prenhes (Figura 11b). Para VLDL, foi observado um efeito de grupo de produção $(\mathrm{P}=0,004)$, dia $(\mathrm{P}=0,001)$, período $(\mathrm{P}=0,01)$ e interação entre grupo x dia x período $(\mathrm{P}=0,009)$ para as concentrações de VLDL, conforme figura 12. 
Foi observado efeito de dia $(\mathrm{P}=0,03)$ e interação entre grupo $\mathrm{x}$ dia $\mathrm{x}$ período $(\mathrm{P}<0,05)$ para as concentrações de LDL, conforme figura 13.

Avaliando as relações entre as relações entre o colesterol e suas frações, foi observado um efeito de período, interação entre dia x período $(\mathrm{P}=0,04)$ e grupo x dia x período $(\mathrm{P}=0,01)$, bem como uma tendência de efeito isolado de dia $(\mathrm{P}=0,06)$ para as mudanças na relação colesterol: HDL, conforme figura 14.

Foi observado uma interação entre dia $\mathrm{x}$ período $(\mathrm{P}<0,05)$ e grupo $\mathrm{x}$ dia $\mathrm{x}$ período $(\mathrm{P}=0,02)$, bem como uma tendência de efeito isolado de período $(\mathrm{P}=0,06)$ para as mudanças na relação colesterol: HDL, conforme figura 15.

As mudanças nas concentrações de colesterol total, triacilglicerol, colesterol-HDL e colesterol-VLDL durante o período de transição e inicio de lactação se provavelmente se dera, devido a um melhor CMS do grupo de vacas de alta produção, o que proporcionou elevação das respectivas frações relativas ao teor de lipídios transportados no sangue (DRAKCLEY et al., 1999). Embora não tenha sido medido o CMS individual, as diferenças na produção de leite por dia por vaca, na condição de claudicação, na mudança ECC, são fatores que apóiam essa hipótese citada. Além disso, os teores e as variações do colesterol e de suas frações no presente estudo foram semelhantes as dos estudos de Maturana Filho (2009) e Gandra (2012), que também trabalharam com gordura protegida no período de transição para as vacas leiteiras.

Schroeder et al. (2002) avaliaram a suplementação de óleo vegetal parcialmente hidrogenado em vacas leiteiras no período de transição e observaram valores de CT e C-HDL semelhantes aos observados neste estudo e no estudo de Maturana Filho (2009), com dietas perfazendo um total de 5,0 13,0 e 18,0 \% de EE na matéria seca dos concentrados experimentais.

No estudo de Gandra (2012) foi observada uma maior variação da concentração de colesterol total no pré-parto, quando as vacas recebiam uma dieta com grão de soja, mas os grupos que recebiam ou uma dieta com gordura protegida, as concentrações de colesterol foram constantes ao longo do período e inicio de lactação, ao contrário do perfil de variação observado no presente estudo. Essas diferenças podem ser explicadas, pelo maior teor de extrato etéreo das dietas e uma menor produção leiteira das vacas do estudo citado.

Os valores médios de triglicerídeos encontrados no presente estudo $(17,64 \pm 5,62 \mathrm{mg} / \mathrm{dl})$ foram semelhantes aos valores médios obtidos para os grupos de animais com puerpério fisiológico $(17,83 \pm 5,37 \mathrm{mg} / \mathrm{dl})$ e superiores as vacas com retenção de anexos fetais $(9,96 \pm 5,61 \mathrm{mg} / \mathrm{dl})$ do estudo de Souza (2005). As vacas do grupo MPV apresentaram os 
menores teores plasmáticos de triglicerídeos no início do período de lactação (média de 16,5 $\pm 1,2 \mathrm{mg} / \mathrm{dl}$ ). Isso provavelmente está ligado a cetose, o que acabou afetando a produção de leite até os $150 \mathrm{DEL}$.

De acordo com Mashek et al. (2005), a infusão de emulsão de sebo ou óleo de linhaça (simulando o aumento de triglicerídeos devido a mobilização de reservas) resultou em maiores concentrações de AGNE e diminuição da glicose e dos triglicerídeos plasmáticos, conseqüentemente, foi constatado um aumento da infiltração hepática de triglicerídeos e diminuição do conteúdo de glicogênio. As vacas que recebiam óleo de linhaça tinham concentrações mais baixas AGNE e BHBA. Portanto, mudanças no perfil lipídico nas dietas de transição, podem minimizar o desenvolvimento de fígado gorduroso.

Sustentando a hipótese do que foi mencionado no parágrafo anterior, no estudo de Bobe et al., (2004), foi verificado que baixas concentrações de fosfolipídios, colesterol livre e triglicerídeos no plasma são relacionados com o fígado gorduroso (GRUM et al., 1996; JORRITSMA et al., 2001). Nesse mesmo estudo, foi verificado que há um papel muito importante do glucagon sobre o transporte de lipídios, principalmente no que diz respeito às concentrações de VLDL (que foram aumentadas). Entretanto, foi verificado que o tratamento com glucagon não é tão eficaz quando feito no verão.

Nos resultados do presente estudo foi observado maiores teores de VLDL para todas vacas em torno do pico de lactação $(3,9 \pm 0,9 \mathrm{mg} / \mathrm{dl})$ exceto para as vacas MPV $(3,1 \pm 0,4$ $\mathrm{mg} / \mathrm{dl})$. Nos demais pontos de coleta até pico de lactação, as vacas de baixa produção tiveram teores mais baixos de VLDL plasmáticos. As variações nos padrões de VLDL (diminuição ou aumento) foram maiores nas vacas de média produção (de 20 a 50\%) durante o período de transição. As vacas de alta produção mantiveram um padrão semelhante por todo período.

Dos resultados do presente experimento, foi verificado que a produção leiteira pode ser afetada de acordo com o percentual e com as relações entre as lipoproteínas plasmáticas. A provável razão, baseada nos achados de outros estudos (PULLINGER; GIBBONS, 1985; BOBE et al., 2004) estaria ligado efeitos do glucagon e da insulina sobre o metabolismo energético, principalmente por mudanças no perfil lipídico. Portanto, aumentar a disponibilidade de substratos gliconeogênicos por via oral ou a administração da dieta pode poupar o uso de proteínas como substratos gliconeogênicos para a ação do glucagon e, assim, não aumentar as concentrações de lipídios no fígado. 
Figura 9 - Variação da concentração de colesterol total $(\mathrm{CT})(\mathrm{mg} / \mathrm{dL})$ no soro de vacas de alta (AP) e média (MP) produção, no inverno (I) e no verão (V)

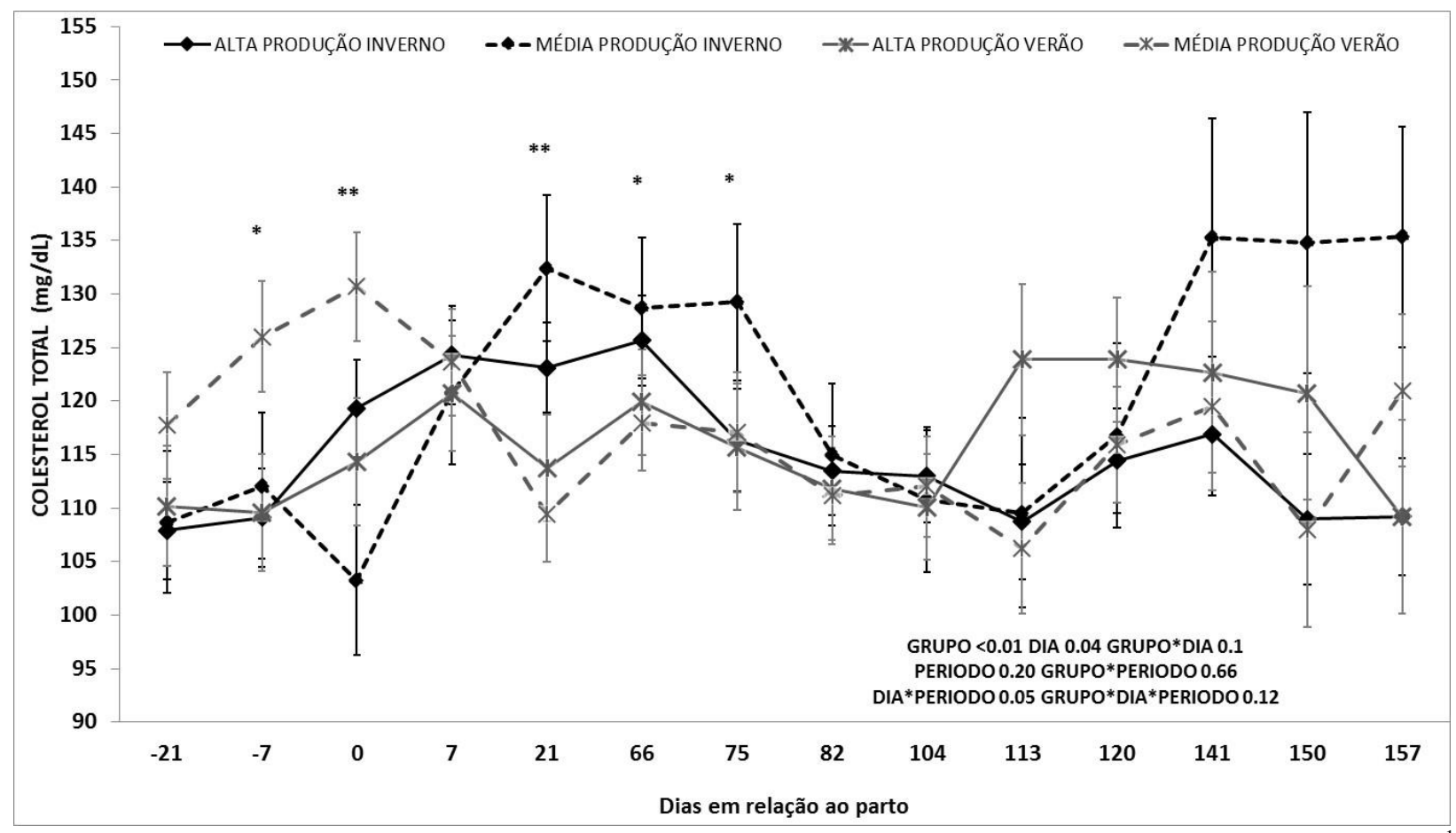

* $\mathrm{P}<0,05$, ** $\mathrm{P}=0,001, * * * \mathrm{P}<0,001$ para as comparações no período de transição e início da lactação. $\mathrm{AP}^{1}$

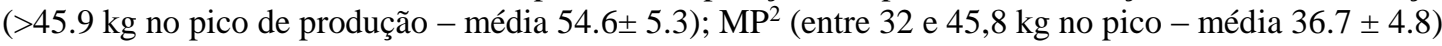

Figura 10 - Variação da concentração de triacilglicerol (TG) $(\mathrm{mg} / \mathrm{dL})$ no soro de vacas de alta (AP) e média (MP) produção, no inverno (I) e no verão (V)

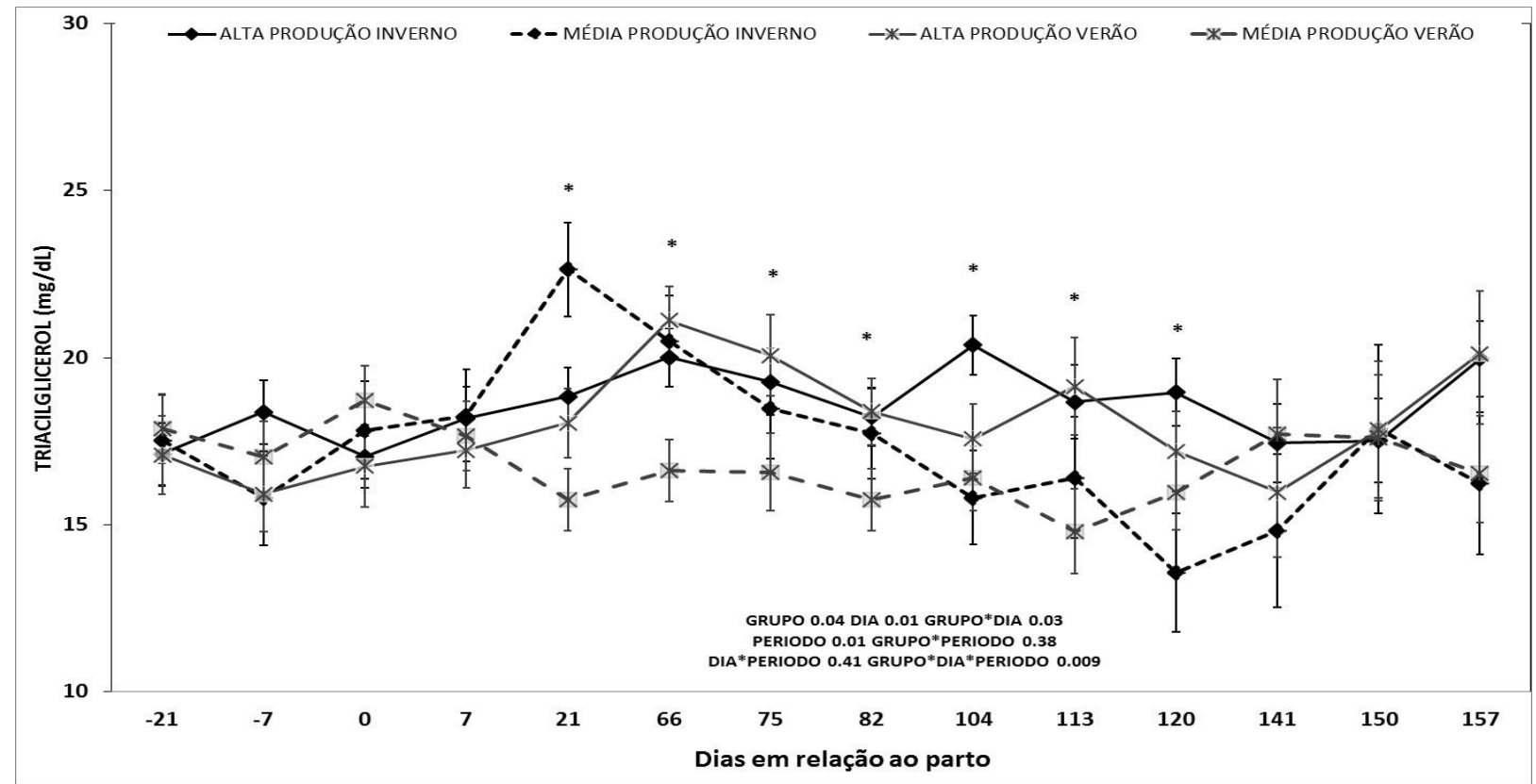

* $\mathrm{P}<0,05, * * \mathrm{P}=0,001, * * * \mathrm{P}<0,001$ para as comparações no período de transição e início da lactação. $\mathrm{AP}^{1}$

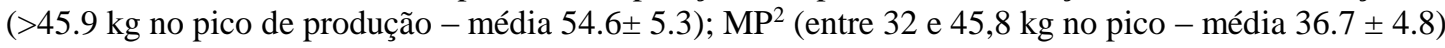


Figura 11A: Variação da concentração do colesterol HDL (HDL) (mg/dL) no soro de vacas de alta (AP) e média (MP) produção, no inverno (I) e no verão (V).

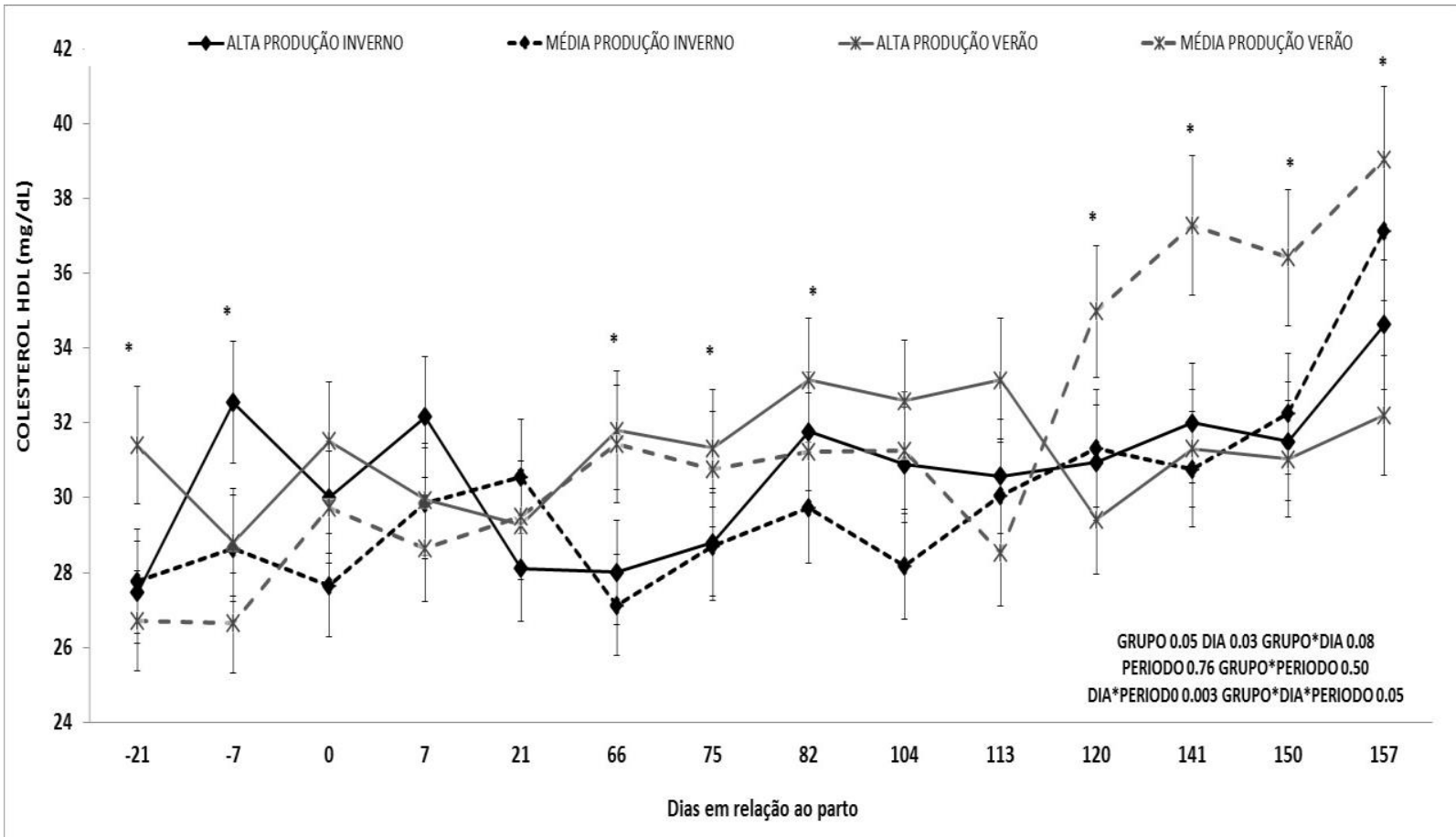

* $\mathrm{P}<0,05, * * \mathrm{P}=0,001, * * * \mathrm{P}<0,001$ para as comparações no período de transição e início da lactação. AP ${ }^{1}$

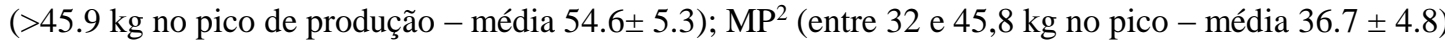

Figura 11B - Variação da concentração do colesterol HDL (HDL) (mg/dL) no soro das vacas leiteiras prenhes à primeira IATF ou vazias aos 150 DEL no inverno (I) e no verão (V)

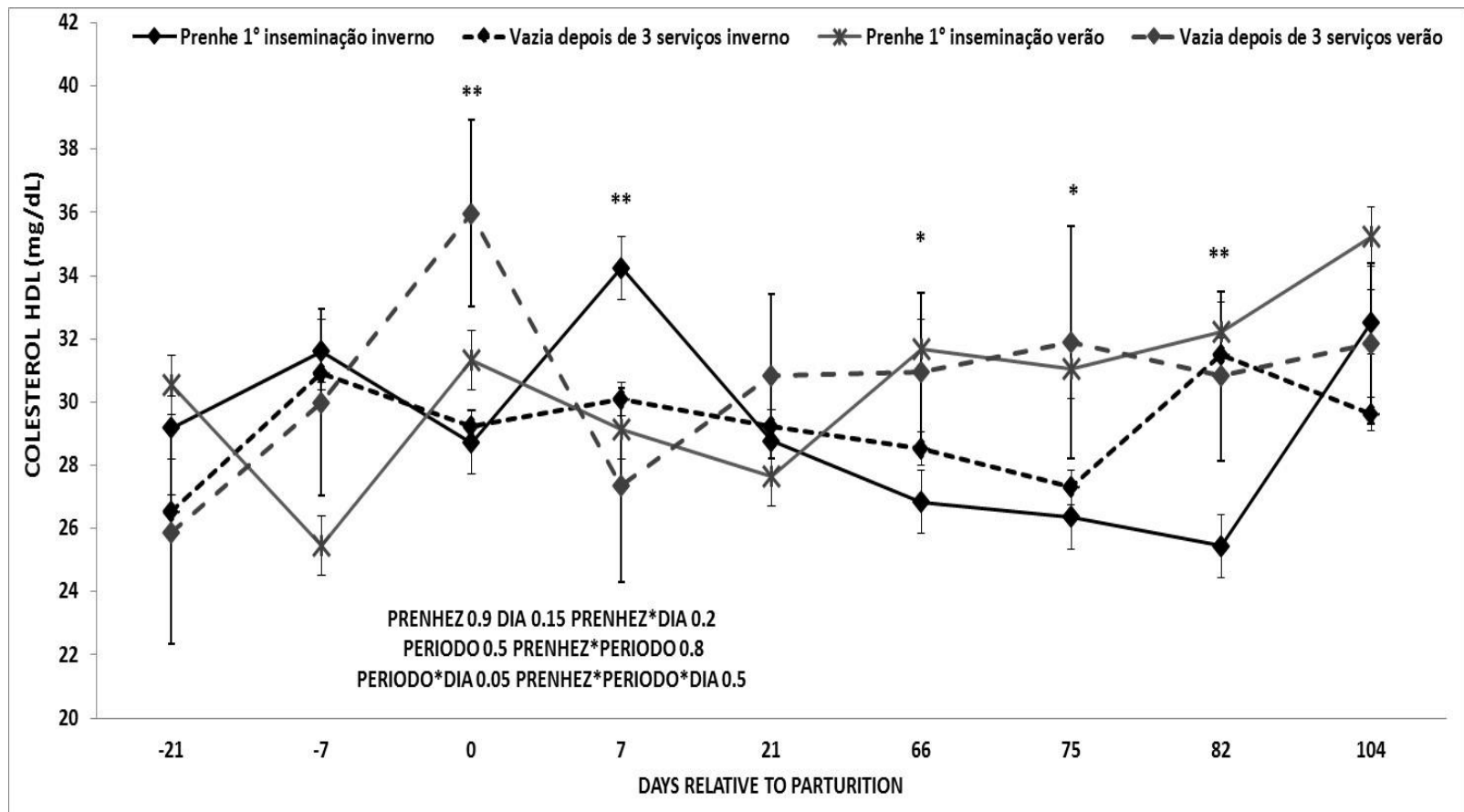

$* \mathrm{P}<0,05, * * \mathrm{P}=0,001, * * * \mathrm{P}<0,001$ para as comparações no período de transição e início da lactação. AP (>45.9 kg no pico de produção - média $54.6 \pm 5.3$ ); $\mathrm{MP}^{2}$ (entre 32 e 45,8 $\mathrm{kg}$ no pico - média $36.7 \pm 4.8$ ) 
Figura 12 - Variação da concentração do colesterol VLDL (VLDL) (mg/dL) no soro de vacas de alta (AP) e média (MP) produção, no inverno (I) e no verão (V)

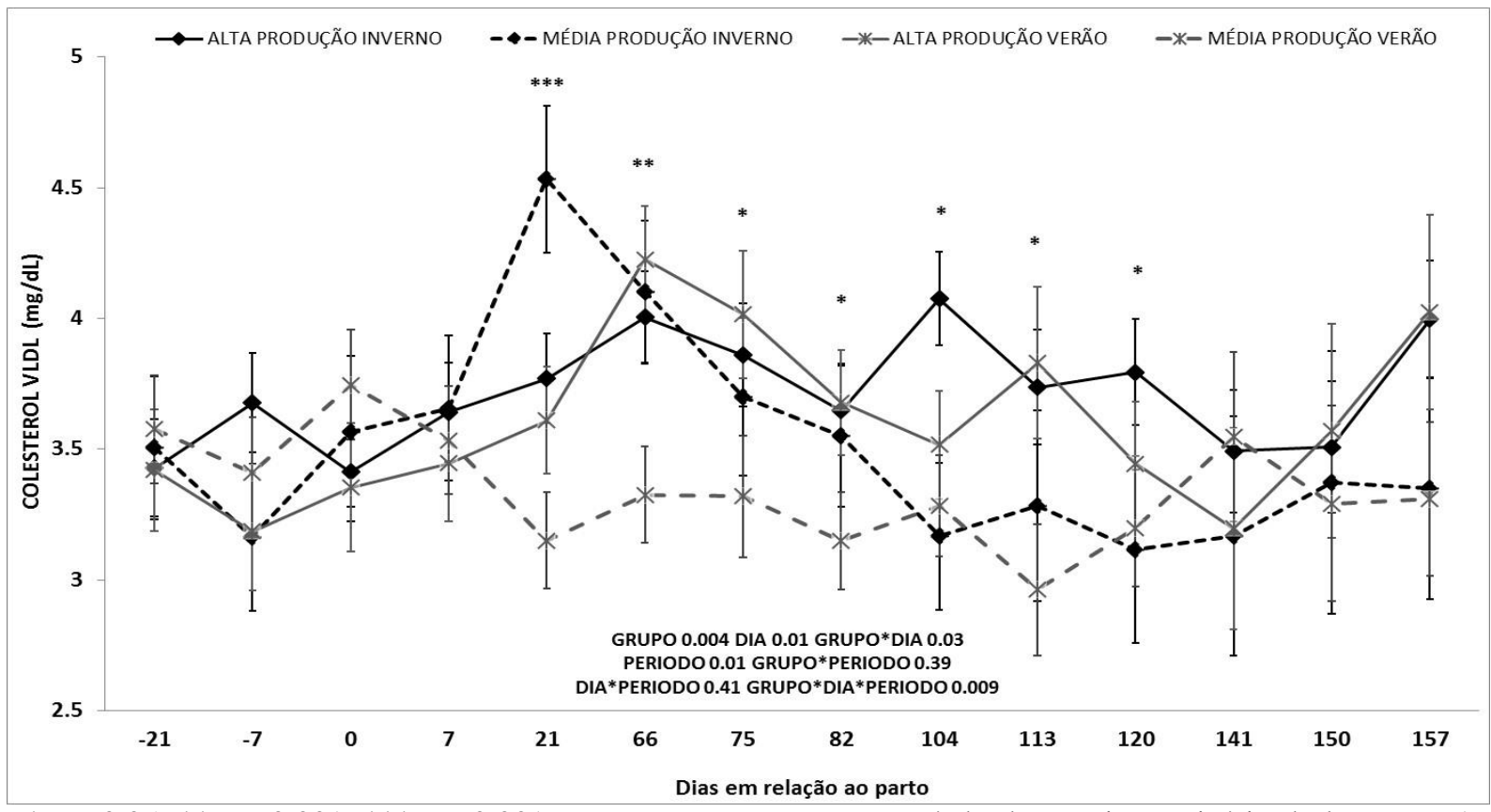

* $\mathrm{P}<0,05, * * \mathrm{P}=0,001, * * * \mathrm{P}<0,001$ para as comparações no período de transição e início da lactação. $\mathrm{AP}^{1}$

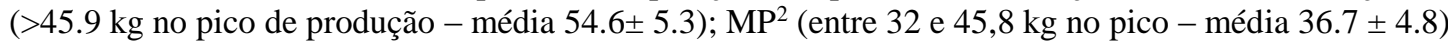

Figura 13 - Variação da concentração de colesterol LDL (LDL) (mg/dL) no soro de vacas de alta (AP) e média (MP) produção, no inverno (I) e no verão (V)

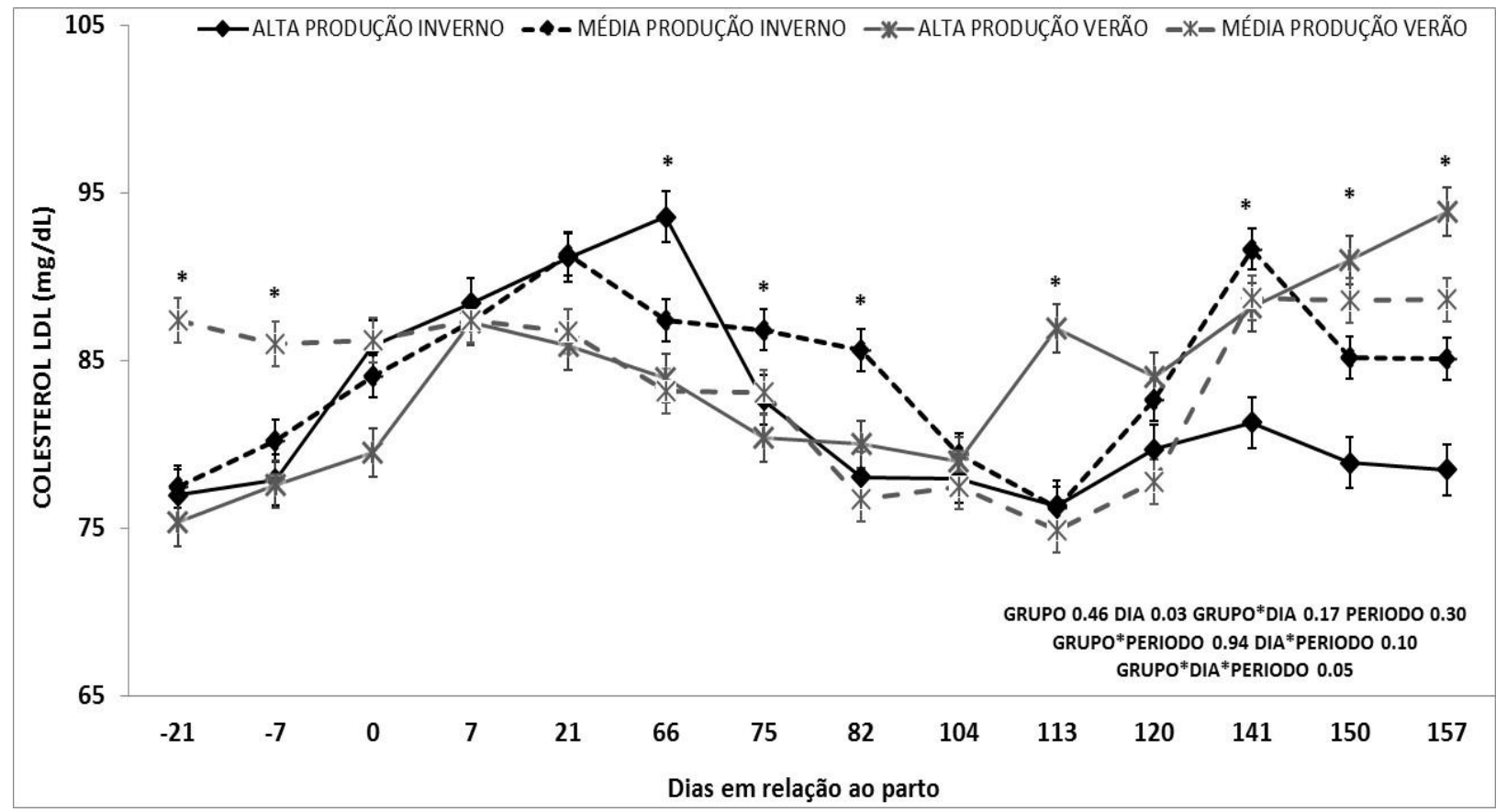

$* \mathrm{P}<0,05, * * \mathrm{P}=0,001, * * * \mathrm{P}<0,001$ para as comparações no período de transição e início da lactação. $\mathrm{AP}^{1}$

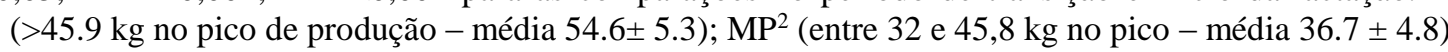


Figura 14 - Variação da relação colesterol:HDL (CTHDL) no soro de vacas de alta (AP) e média (MP) produção, no inverno (I) e no verão (V)

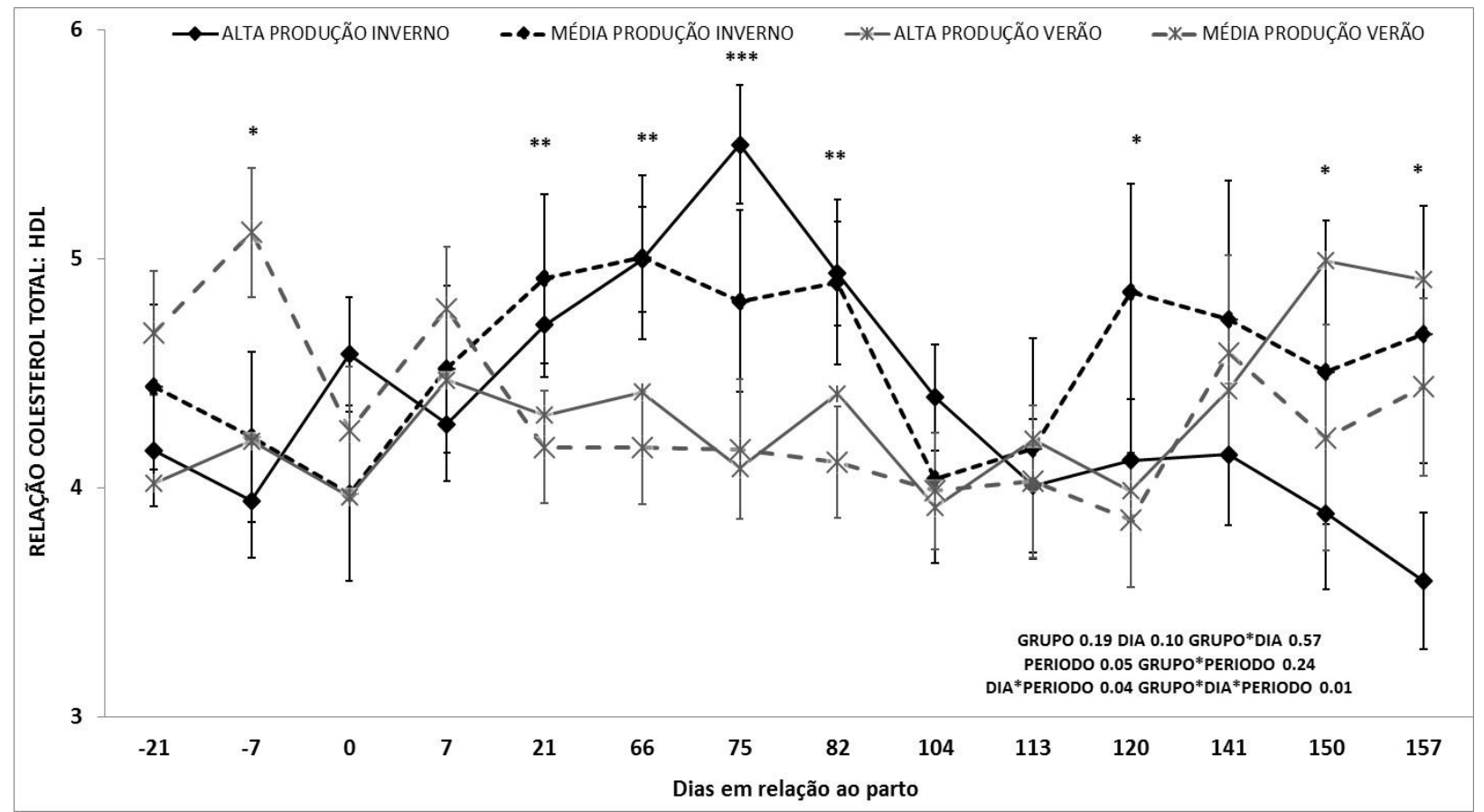

* $\mathrm{P}<0,05, * * \mathrm{P}=0,001, * * * \mathrm{P}<0,001$ para as comparações no período de transição e início da lactação. AP

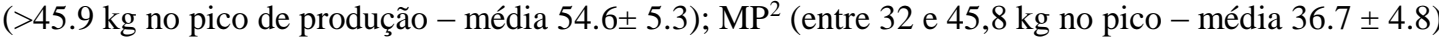

Figura 15 - Variação da relação LDL: HDL (LDLH) no soro de vacas de alta (AP) e média (MP) produção, no inverno (I) e no verão (V)

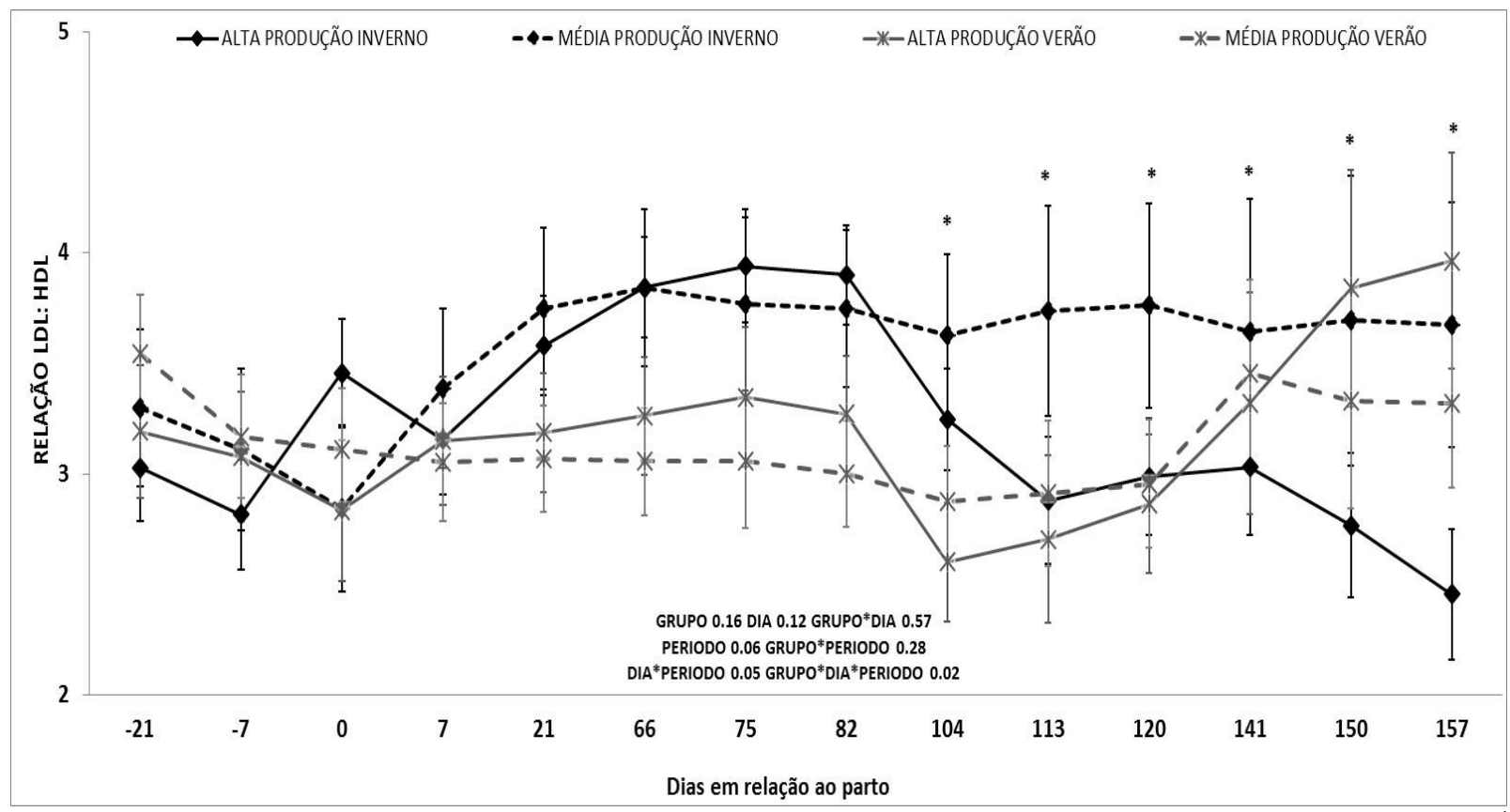

$* \mathrm{P}<0,05, * * \mathrm{P}=0,001, * * * \mathrm{P}<0,001$ para as comparações no período de transição e início da lactação. $\mathrm{AP}^{1}$

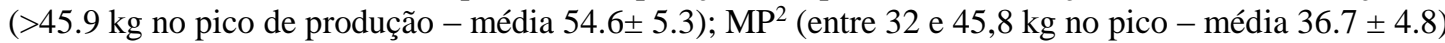


3.5.4 AGNE e BHBA

As diferenças no perfil lipídico, baseado na mobilização de reservas corporais, foram observadas tanto no modelo animal de grupo de produção nas estações do ano, como no modelo animal baseado na prenhez. Foi observado um efeito de grupo de produção (P $<0,001)$, dia $(\mathrm{P}<0,001)$ e interações entre dia $\mathrm{x}$ estação $(\mathrm{P}<0,001)$ e grupo $\mathrm{x}$ dia $\mathrm{x}$ estação do ano $(\mathrm{P}=0,009)$, conforme figura 16A. Houve somente um efeito de dias $(\mathrm{P}<0,001)$ para as variações das concentrações de AGNE no modelo de prenhez. Houve tendência de efeito de estação do ano $(\mathrm{P}=0,1)$, e de interação entre Prenhez e dias $(\mathrm{P}=0,1)$, Prenhez e dia $(\mathrm{P}=0,1)$ e Período e dias $(\mathrm{P}=0,1)$, conforme figura $16 \mathrm{~B}$.

Houve efeito de grupo de produção $(\mathrm{P}=0,002)$, estação $(\mathrm{P}=0,03)$ e tendência de efeito de dias $(\mathrm{P}=0,08)$ para as concentrações de BHBA. Houve interação entre grupo x dia $(\mathrm{P}=0,03)$ e grupo $x$ dia $x$ período $(\mathrm{P}=0,003)$ e tendência de interação entre grupo e estação $(\mathrm{P}=0,09)$ para as concentrações de BHBA, baseado no modelo de produção, conforme figura 17A.

De acordo com o modelo de prenhez, houve efeito de dia $(\mathrm{P}=0,03)$, estação $(\mathrm{P}=0,01)$ e tendências de efeito de grupo prenhez $(\mathrm{P}=0,09)$ e de interação entre prenhez x dia $(\mathrm{P}=0,1)$ para os teores de BHBA, conforme figura 17B.

Durante o período de transição até o pico de lactação, o perfil de variação e os teores de AGNE foram semelhantes entre as vacas APV e MPV. Embora os teores de AGNE tenham sido menores para as vacas API e MPI durante o período de transição, o perfil de variação e os teores plasmáticos médio não tiveram um padrão semelhante entre estes grupos.

Embora os padrões de variação tenham sido diferentes entre os grupos e períodos na maioria dos pontos avaliados. As concentrações de AGNE se apresentaram baixas no préparto $0,5 \pm 0,03 \mathrm{mmol} / \mathrm{L}$ e aumentaram de forma acentuada na primeira semana pós parto para as vacas do verão. Esses valores no pré parto e esse aumento na primeira semana pós parto foram da mesma magnitude dos valores encontrados no estudo de Maturana Filho (2009), mas, foram inferiores aos de Gandra (2012), onde foi observado pico médio de 0,936 mmol/L na concentração de AGNE no $7^{\circ}$ dia de lactação para todas as dietas experimentais (com diferentes fontes de gordura), sendo que a dieta com sais de cálcio (SC) nesse estudo citado, apresentou maior concentração $(1,071 \mathrm{mmol} / \mathrm{L})$. Isso provavelmente está relacionado ao baixo CMS do grupo SC e pelas diferenças na condição de ambiência para os animais do estudo citado. 
Após a primeira semana de lactação todos os grupos experimentais, exceto, MPI, apresentaram constante diminuição nas concentrações de AGNE até o pico de lactação. Após o diagnóstico de gestação da primeira inseminação aos 104 DEL, foi observada uma diferença significativa entre as vacas de alta e média produção, pois, a partir desse ponto, somente as vacas que não ficaram prenhes na primeira inseminação, que foram coletadas.

As vacas MPI o pico de AGNE $(0,57 \pm 0,06 \mathrm{mmol} / \mathrm{L})$ ocorreu somente no pico de lactação. As vacas API tiveram os maiores teores de AGNE no pico de lactação também, entretanto, os valores máximos observados foram $(0,42 \pm 0,03 \mathrm{mmol} / \mathrm{L})$. Após o pico de lactação estes grupos mantiveram um padrão de variação semelhante até o final do período experimental.

Duske et al. (2009) avaliando 80 vacas da raça Holandesa com média de produção de $35,0 \mathrm{~kg} / \mathrm{vaca} /$ dia utilizando as dietas controle com 2,7 \% de EE e com gordura 5,5 \% de EE, semelhante as do presente experimento, observaram valores de AGNE mais elevados aos obtidos neste estudo 0,85 $\mathrm{mmol} / \mathrm{L}$ para AGNE e $1,10 \mathrm{mmol} / \mathrm{L}$ para as concentrações de BHBA aos 21 dias pós-parto.

De acordo com Grummer et al. (1993) esse rápido aumento nas concentrações de AGNE no pós-parto pode ser resultado de uma regulação fisiológica que ocorre proveniente da redução acentuada no consumo de matéria seca e da alteração de sinais homeostáticos desencadeados pelo hormônio do crescimento $(\mathrm{GH})$, que gera um aumento na liberação de hormônios lipolíticos.

Apesar de não ter sido observado efeito de grupo, baseado no modelo de prenhez e de dias para o modelo de produção nas concentrações de BHBA (mmol/L) foi observado que vacas de alta produção ou vacas que ficam prenhes no primeiro serviço, tiveram menores concentrações de BHBA no período de transição. As vacas API e APV tiveram um padrão semelhante de variação deste metabólito no período pós-parto.

No estudo de Garverick et al. (2013) foi verificado que as concentrações de glicose e AGNE no plasma são significativamente maiores e menores, respectivamente, durante o período de transição, em vacas que emprenham no primeiro serviço. Esses achados estão em conformidade com o presente estudo.

Vacas com maior NEFA foram, presumivelmente, as mais predispostas a produzirem menos leite no pico de lactação e terem maior incidência de problemas metabólicos como retenção de placenta, metrite e cetose (conforme Tabelas 5A,B). Vacas acima de um limiar crítico de 1,2 mmol/L de AGNE e 0,5 mmol/L de BHBA tem um aumento na probabilidade de desenvolver doenças metabólicas e infecciosas no início do período pós parto e serem 
descartadas (OSPINA et al., 2010; CHAPINAL et al., 2011). Doenças metabólicas como cetose (clinica ou subclinica) foram associadas com a redução da fertilidade em vacas leiteiras de alta produção (OSPINA et al., 2010), pois além da alta taxa de mobilização de gordura corporal, voltada a síntese de lactose no leite (BAUMAN; CURRIE, 1980), a baixa de glicose, devido ao baixo CMS, diminui a disponibilidade deste metabólito para as gônadas, oócitos e embrião (WATHES et al., 2011; GREEN et al., 2012). Portanto, essas diferenças nos teores plasmáticos de NEFA e BHBA observadas no presente experimento entre as prenhes e vazias, refletem possíveis alterações na integridade de folículos e oócitos durante os 3 primeiros serviços. No estudo de Webb et al. (2003), foi observado que vacas que tiveram altos teores de AGNE e BHBA no inicio do período pós parto, tiveram um comprometimento da qualidade oocitária até 100 DEL. Esses dados, corroboram com as hipóteses de Britt (1992) e de Leroy et al. (2005a b).

As concentrações de AGNE, BHBA e glicose plasmática, indicaram uma maior gravidade do balanço energético negativo e foram boas preditoras de saúde e fertilidade, tanto do modelo baseado na produção como no modelo baseado na prenhez ao primeiro serviço. Assim como no presente estudo, Garverick et al. (2013); VanHoeck et al. (2013) e Van Knegsel et al. (2007), demonstram a importância desses três metabólitos sobre a ciclicidade, qualidade do oócito e sucesso de prenhez no primeiro serviço em vacas leiteiras, que corrobora com os estudos de (PASQUALI et al., 2003; LEROY et al., 2005 ab; ROBKER et al., 2009; JUNGHEIM et al., 2011a,b). 
Figura 16A Variação da concentração de ácidos graxos não esterificados (AGNE) (mmol/L) no soro de vacas de alta (AP) e média (MP) produção, no inverno (I) e verão (V)

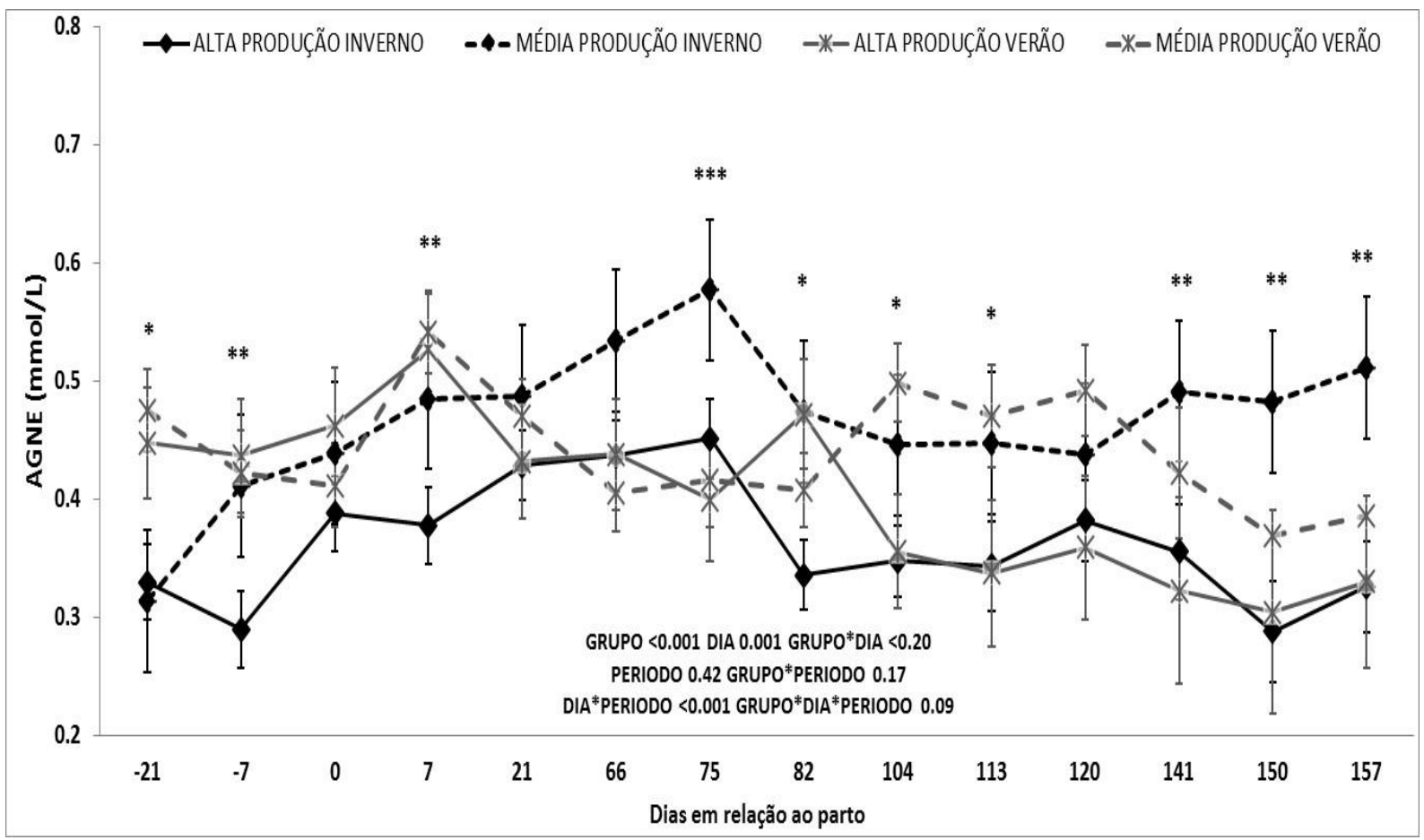

* $\mathrm{P}<0,05, * * \mathrm{P}=0,001, * * * \mathrm{P}<0,001$ para as comparações no período de transição e início da lactação. $\mathrm{AP}^{1}$

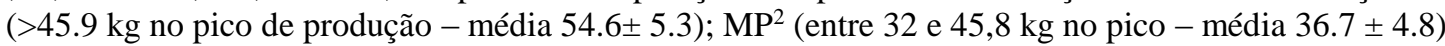

Figura 16B - Variação da concentração de ácidos graxos não esterificados (AGNE) (mmol/L) no soro das vacas leiteiras prenhes à primeira IATF ou vazias aos 150 DEL no inverno (I) e no verão (V)

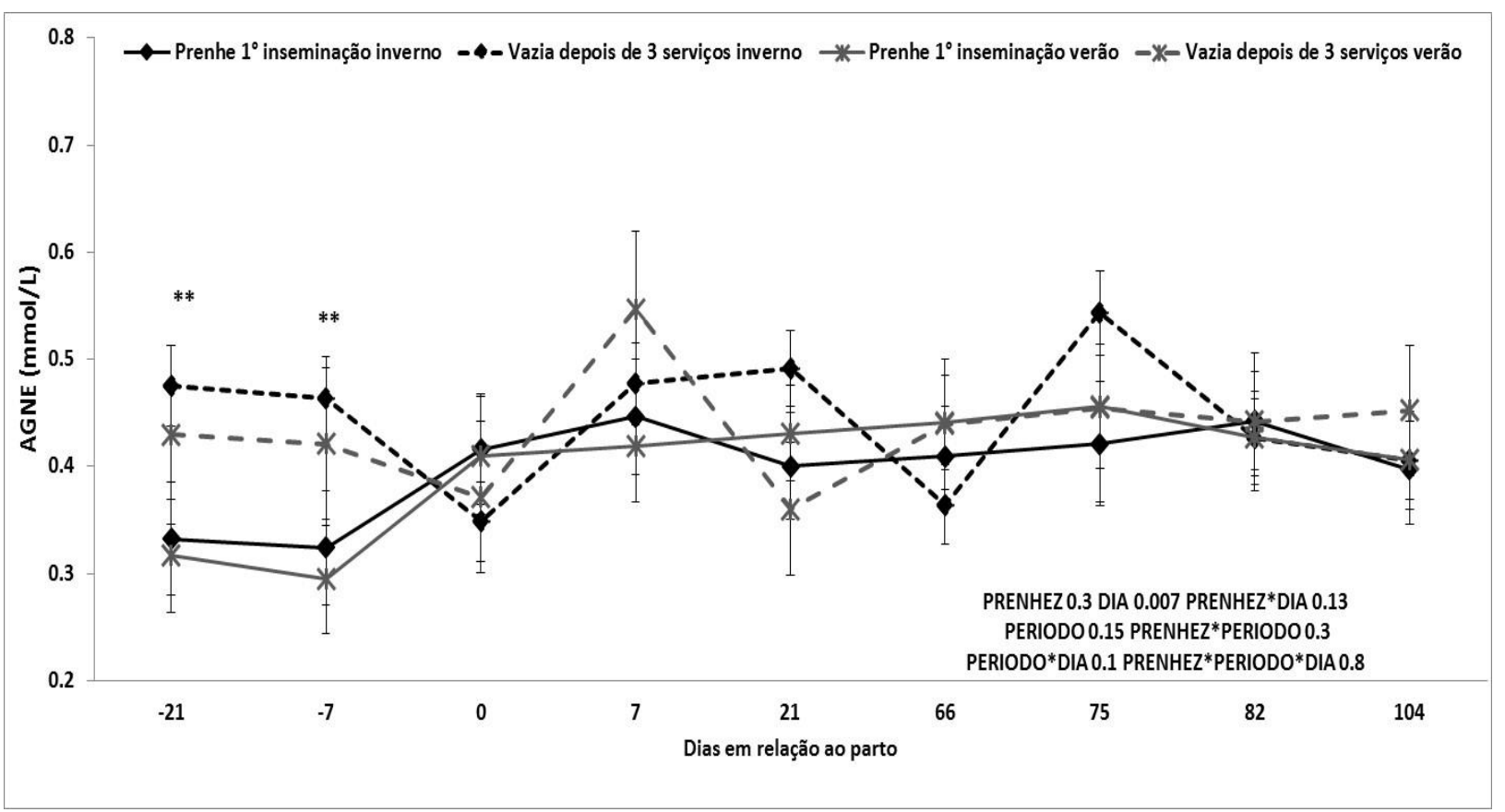

$* \mathrm{P}<0,05, * * \mathrm{P}=0,001, * * * \mathrm{P}<0,001$ para as comparações no período de transição e início da lactação. AP

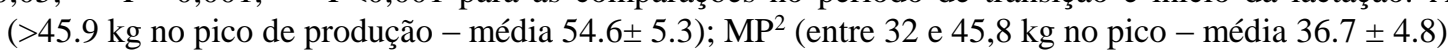


Figura 17A - Variação da concentração de beta hidroxibutirato (BHBA) (mmol/L) no soro de vacas de alta (AP) e média (MP) produção, no inverno (I) e no verão (V)

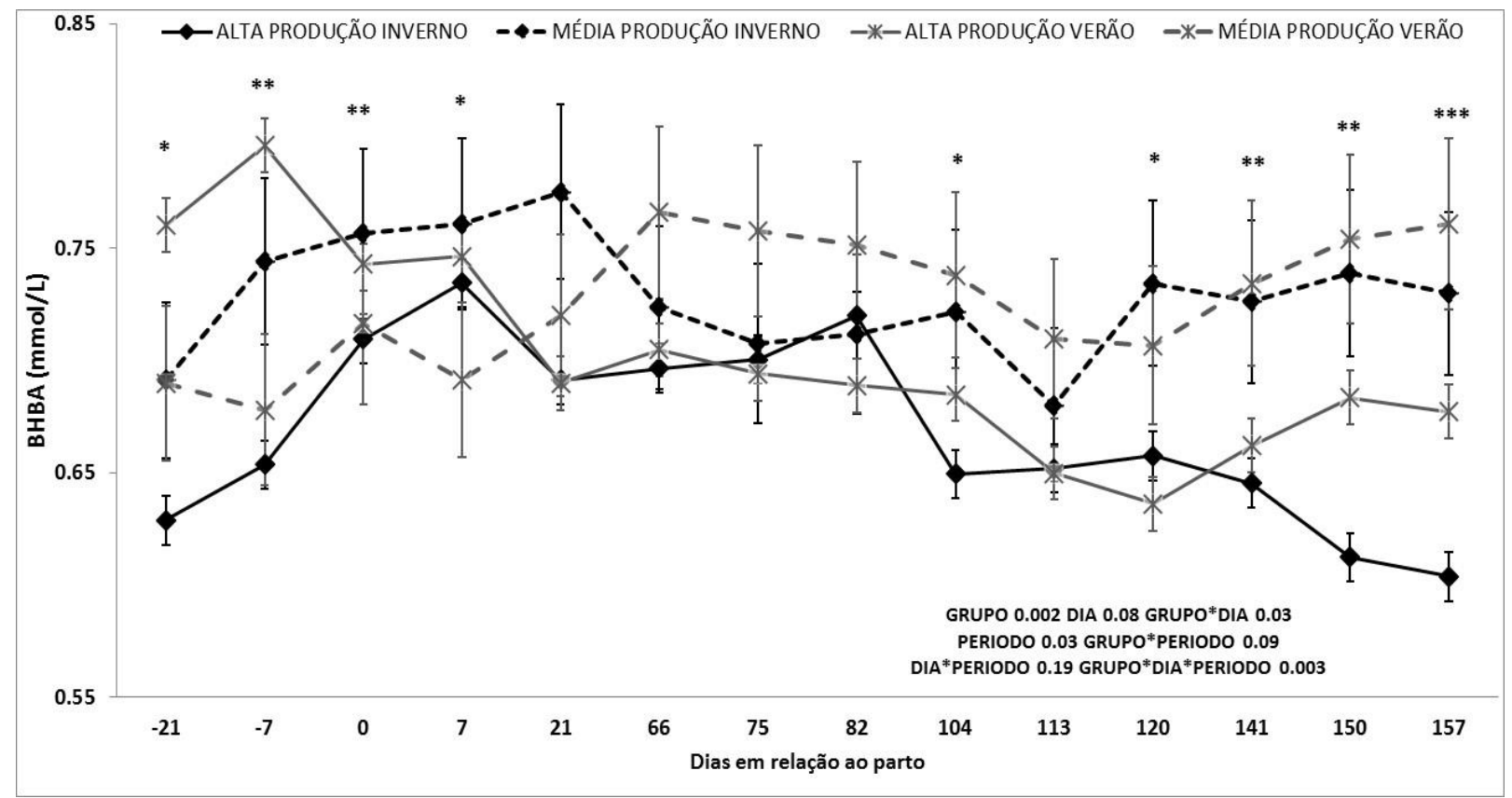

$* \mathrm{P}<0,05, * * \mathrm{P}=0,001, * * * \mathrm{P}<0,001$ para as comparações no período de transição e início da lactação. $\mathrm{AP}^{1}$

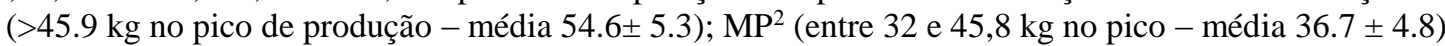

Figura 17B - Variação da concentração de beta hidroxibutirato (BHBA) (mmol/L) no soro das vacas prenhes à primeira IATF ou vazias aos 150 DEL no inverno (I) e no verão (V)

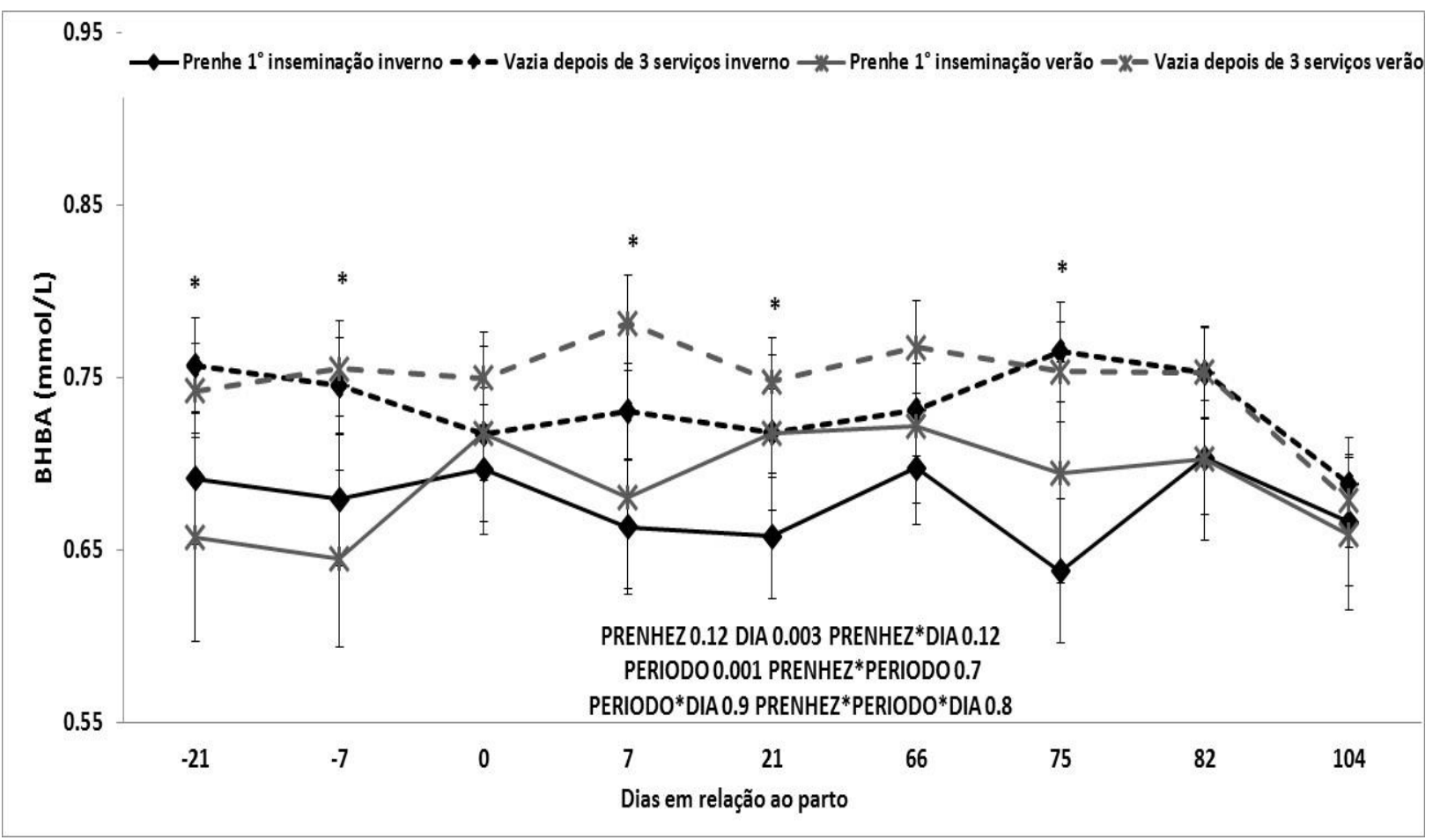

$* \mathrm{P}<0,05, * * \mathrm{P}=0,001, * * * \mathrm{P}<0,001$ para as comparações no período de transição e início da lactação. AP

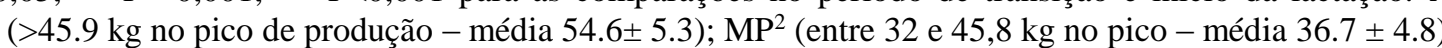


3.5.5 Metabolismo de Nitrogênio

Foi observado um efeito de dia $(\mathrm{P}<0,001)$ e interações entre grupo $\mathrm{x}$ dia $(\mathrm{P}<0,001)$, dia $\mathrm{x}$ estação $(\mathrm{P}<0,05)$ e grupo $\mathrm{x}$ dia $\mathrm{x}$ estação do ano $(\mathrm{P}=0,01)$ e tendência de efeito de grupo de produção $(\mathrm{P}=0,07)$ para as concentrações de uréia, conforme figura 18A.

Ainda em relação às variações de uréia. Houve efeito de grupo de prenhez $(\mathrm{P}=0,04)$, dias $(\mathrm{P}=0,007)$, interação entre prenhez $x$ dia $(\mathrm{P}=0,03)$. Houve tendência de efeito de prenhez x período $(\mathrm{P}=0,06)$ e período $\mathrm{x}$ dias $(\mathrm{P}=0,1)$, conforme figura $18 \mathrm{~B}$.

Houve efeito de dia $(\mathrm{P}<0,001)$ e interações entre grupo $\mathrm{x}$ dia $(\mathrm{P}<0,001)$, dia $\mathrm{x}$ estação $(\mathrm{P}=0,04)$ e grupo $\mathrm{x}$ dia $\mathrm{x}$ estação do ano $(\mathrm{P}<0,05)$ e tendência de efeito de grupo de produção $(\mathrm{P}=0,09)$ para as concentrações de nitrogênio uréico no sangue, conforme figura 19A. Houve efeito de grupo de prenhez $(\mathrm{P}<0,05)$, dias $(\mathrm{P}=0,03)$, período $(\mathrm{P}=0,04)$, interação entre prenhez $\mathrm{x}$ dia $(\mathrm{P}=0,01)$. Houve tendência de efeito de prenhez $\mathrm{x}$ período $(\mathrm{P}=0,06)$, conforme figura 19B.

Não foram observadas diferenças nos padrões de variação, nem nos valores de creatinina no soro, tanto no modelo animal baseado no grupo de produção, como no grupo de fertilidade $(\mathrm{P}>0,05)$ no presente estudo.

As vacas no período do inverno tiveram valores plasmáticos e variações semelhantes de uréia durante o período de transição, diferente de ambos os grupos no verão. Após o período de transição, as vacas APV tiveram valores mais elevados, bem como um padrão de variação de uréia diferente dos demais grupos até os 100 DEL.

De acordo com o modelo de prenhez, as vacas vazias, independente da estação do ano, tiveram um padrão de variação semelhante durante a transição e durante o inicio do período de lactação, entretanto, no período de transição, as vacas vazias do período de verão tiveram valores mais elevado de uréia, enquanto que no pico de lactação foram as do inverno.

As vacas que ficaram prenhes na primeira inseminação mantiveram um padrão de variação semelhante durante o período de transição em ambos os períodos. Além disso, os teores médios durante inicio de lactação até os 100 dias, não ultrapassaram $15 \mathrm{mg} / \mathrm{dL}$.

Os padrões de variação de nitrogênio uréico foram semelhantes aos padrões de variação de uréia durante o inicio de lactação. No entanto, durante período de transição as variações deste metabólito foram diferentes entre os grupos de fertilidade. Entre as vacas vazias após 3 serviços, as concentrações foram diferentes durante o período de transição e durante o pico de lactação. 
Essas mudanças nos teores e nos padrões de variação entre os grupos de produção e de fertilidade no presente estudo foram diferentes nas duas estações do ano, provavelmente, devido a uma maior utilização dos aminoácidos musculares, principalmente os glicogênicos, com o intuito de suprir um déficit de energia durante o período de transição. Por isso houve não houve um padrão de variação desses metabólitos. Apoiando essa hipótese, alguns estudos têm mostrado que as mudanças na condição corporal durante o período de transição têm sido um dos principais fatores ligados ao metabolismo de nitrogênio em vacas leiteiras de alta produção (DRACKLEY, 1999; VANDEHAAR et al., 1999).

Além disso, um maior aporte de aminoácidos para a glândula mamária tem sido apontado como um dos fatores de maior importância na síntese de lactose (OVERTON; WALDRON, 2004). No presente estudo, os teores de lactose, assim como os de nitrogênio uréico foram mais elevados tanto para as vacas que não ficaram prenhes no primeiro serviço, como para as vacas de alta produção, corroborando com o estudo de Overton e Waldron (2004) e de Maturana Filho (2009). Entretanto, os teores plasmáticos observados no período de transição e inicio de lactação no presente estudo, são inferiores aos estudos citados. Que provavelmente estão relacionados às diferenças na dieta, produção leiteira e sistema de estabulação dos animais.

$\mathrm{O}$ aumento dos teores de uréia e nitrogênio uréico a partir do dia -7 , em geral se estenderam até a sexta semana pós-parto e estão relacionados a balanço negativo de nitrogênio. Esses achados estão de acordo com Grummer (1995) e Chibisa et al. (2008).

Esse balanço negativo de nitrogênio nas vacas no período de transição, está relacionado também com a sobrecarga de metabolização hepática de gordura (GRUMMER, 1995; NRC, 2001). Nas vacas que ficaram prenhes na primeira inseminação foram observados alguns pontos importantes relacionados ao metabolismo hepático e que confirmam essas variações no metabolismo nitrogenado, como: maiores teores de triglicerídeos, glicose e colesterol na circulação, juntamente com baixos teores de AGNE, BHBA e VLDL. Estes achados (mais baixos teores de uréia e nitrogênio uréico) refletem provavelmente uma melhor eficiência na transformação de amônia em uréia.

Quando os teores de nitrogênio aumentam no sangue, existe um aumento de gasto energético para metabolizar esses compostos, o que ocasionaria um agravamento do balanço energético negativo, pois de acordo com o NRC (2001), para cada grama de N excretado via urina, são gastos 7,2 Mcal de energia. A retenção de nitrogênio no pré-parto de vacas leiteira sempre será positivo, mesmo com o déficit energético. Já no pós-parto imediato a retenção pode ficar negativa chegando a déficits de até 120 gramas/dia por volta da $1^{\mathrm{a}}$ a $2^{\mathrm{a}}$ semana de 
lactação em vacas com produção média de $38,5 \mathrm{~kg} / \mathrm{dia}$, assim como as do presente estudo, portanto, levando aos aumentos observados nestes metabólitos.

O retorno ao balanço nitrogenado positivo parece ter ocorrido por volta do dia 21 pós parto nas vacas que ficaram prenhes no primeiro serviço e foi caracterizado por uma redução de 10 a 15\% nos teores destes metabólitos, o que está de acordo com o estudo de Chibisa et al. (2008), entretanto, no estudo citado, esse restabelecimento só ocorreu por volta da $5^{\mathrm{a}}$ a $6^{\mathrm{a}}$ semana de lactação.

Ainda que a produção de amônia e uréia possa ser minimizada balanceando PDR e PNDR, o consumo elevado para manter a produção de leite e a variação na produção de proteína microbiana no rúmen torna difícil a previsão exata da disponibilidade de aminoácidos específicos (BUTLER, 1998,2004,2008 NRC 2001; BUTLER; SMITH, 1989; BUTLER et al., 2004). Portanto os maiores teores de uréia e nitrogenio uréico para as vacas API provavelmente foi conseqüência, de um alto CMS, por isso, provavelmente, a taxa de prenhez deste grupo de vacas não foi diferente das vacas de baixa produção. Em muitos estudos, os aumentos nas concentrações de NUS foram correlacionados com menor fertilidade em vacas leiteiras, tanto em confinamento como em rebanhos mantidos a pasto (BUTLER, 1998; WESTWOOD et al., 1998; WITTWER, 2000; TAMMINGA, 1997).

Alguns estudos mostram uma redução de cerca de $20 \%$ na taxa de prenhez quando o NUS é maior que > $19 \mathrm{mg} / \mathrm{dL}$ (BUTLER et al., 1996), entretanto, no presente estudo foram observados efeitos sobre a fertilidade, com teores mais baixos do que estes. Os resultados do presente estudo estão de acordo com os resultados de Rajala-Schultz et al. (2001), que verificaram uma redução na fertilidade de vacas leiteiras, quando os teores estavam por volta de 15,4 mg/dL. Em alguns estudos foram observados que teores de nitrogênio ureico a partir de $12 \mathrm{mg} / \mathrm{dL}$ já são capazes de gerar uma acidificação do pH uterino (ELROD et al., 1993ab), consequentemente, altera a disponibilidade de minerais que serão importantes para o desenvolvimento embrionário (HAMMON et al., 2005).

No presente estudo foi observado um aumento dos teores de ureia e nitrogenio ureico na primeira semana após a inseminação no grupo de vacas que não ficaram prenhes. Corroborando com estes dados, no estudo de Rhoads et al. (2006), também foi observado taxas de prenhez mais baixas em receptoras de embrião que tinham teores de uréia acima de $15,4 \mathrm{mg} / \mathrm{dl}$. Além destes efeitos sobre o $\mathrm{pH}$ uterino, alguns estudos in vitro mostraram que a uréia atua sobre a maturação do oócito (DE WIT et al., 2001; OCON; HANSEN, 2003), sendo, portanto, a fertilidade no primeiro serviço explicada também pelos efeitos deletérios de altos teores de $\mathrm{N}$ no plasma durante o período de transição, sobre a qualidade do oócito. 
Figura 18A - Variação da concentração de uréia (UR) (mg/dL) no soro de vacas de alta (AP) e média (MP) produção, no inverno (I) e no verão (V)

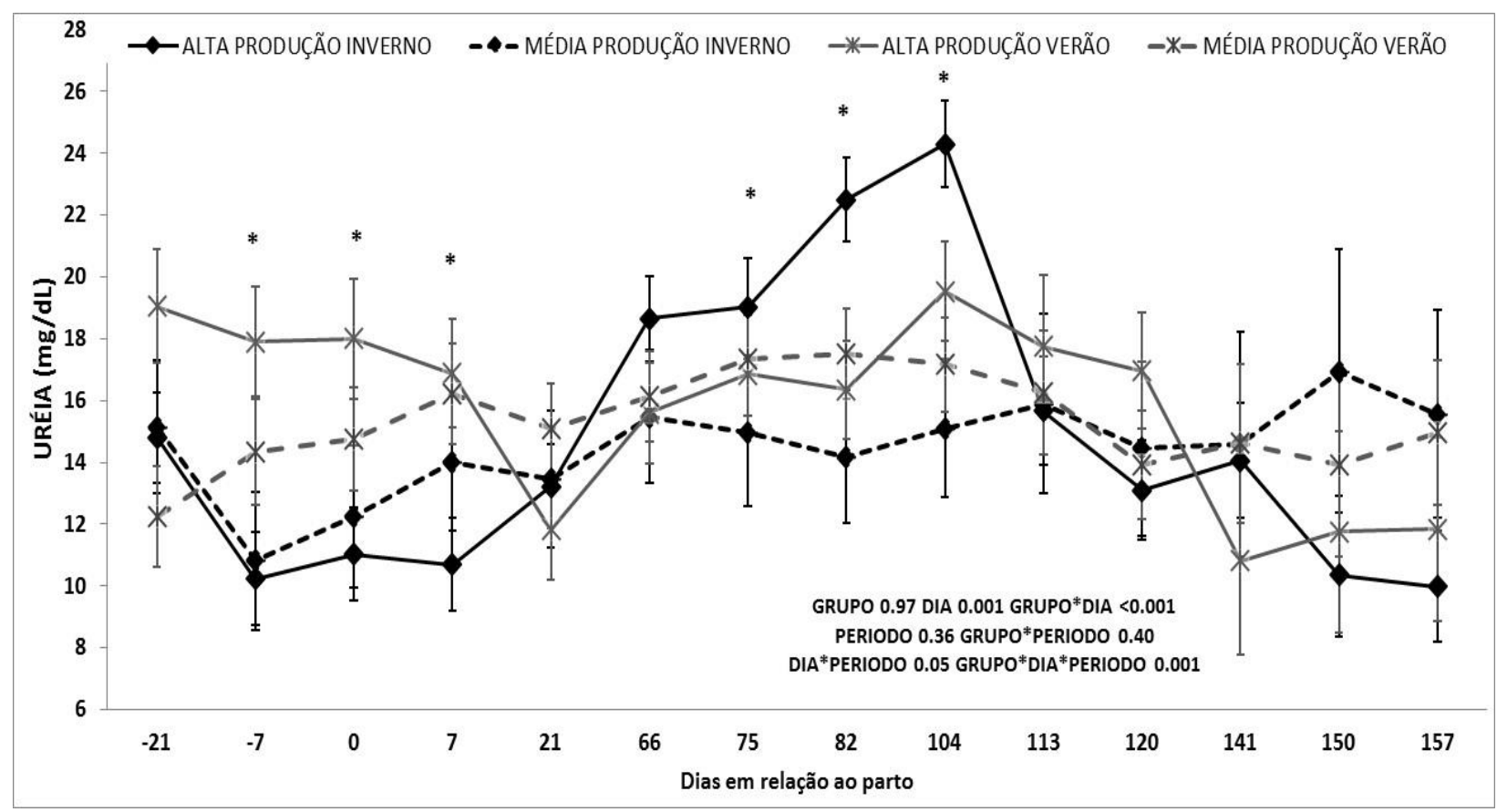

* $\mathrm{P}<0,05, * * \mathrm{P}=0,001, * * * \mathrm{P}<0,001$ para as comparações no período de transição e início da lactação. AP

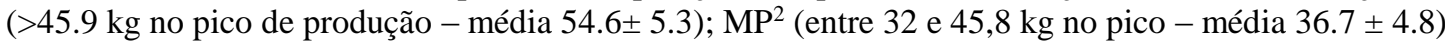

Figura 18B - Variação da concentração de uréia (UR) $(\mathrm{mg} / \mathrm{dL})$ no soro das vacas leiteiras prenhes à primeira IATF ou vazias aos 150 DEL no inverno (I) e no verão (V)

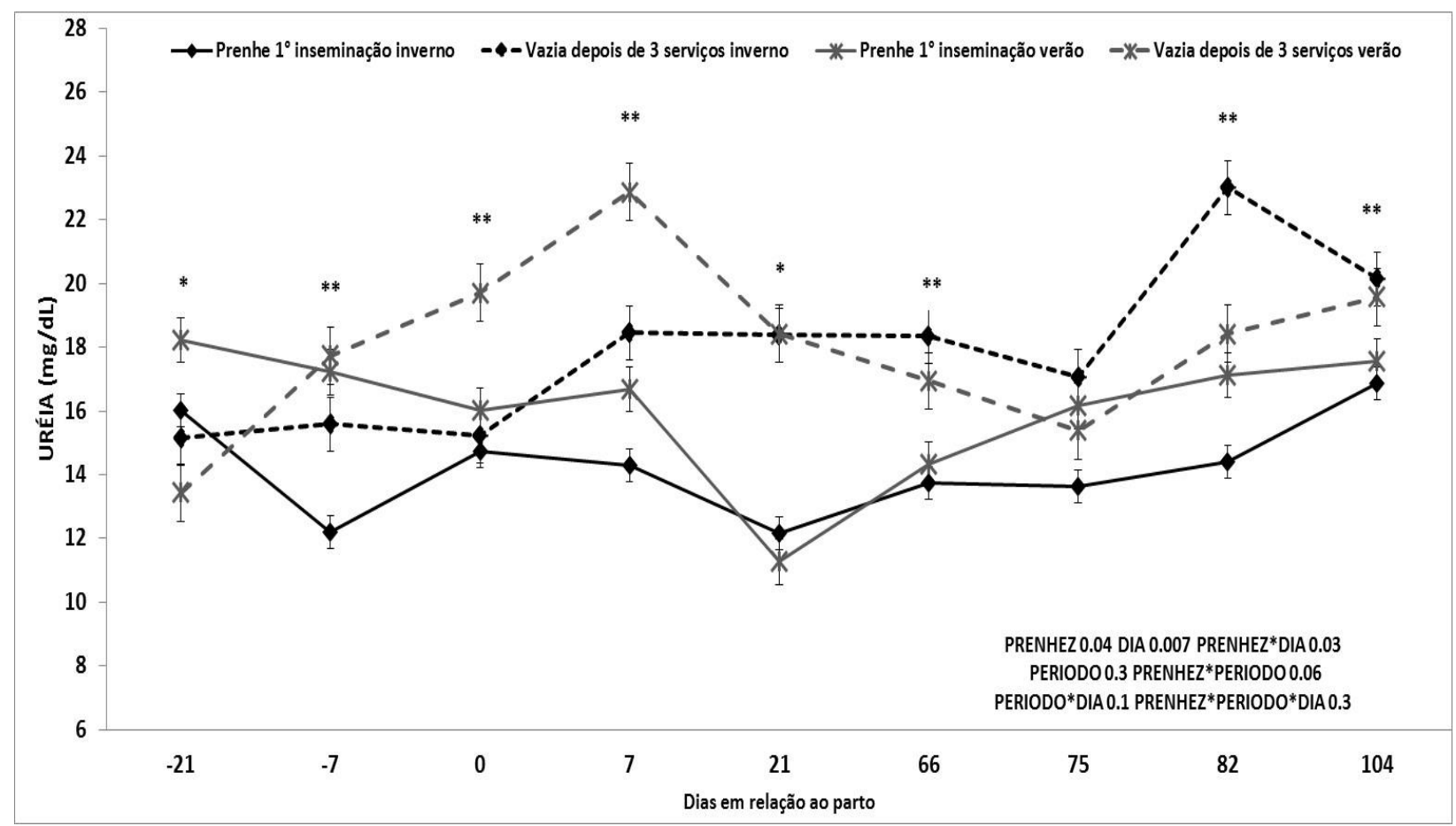

$* \mathrm{P}<0,05, * * \mathrm{P}=0,001, * * * \mathrm{P}<0,001$ para as comparações no período de transição e início da lactação. AP

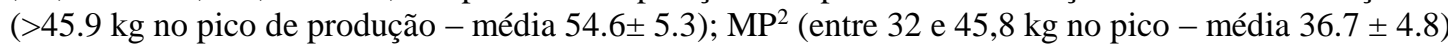


Figura 19A - Variação da concentração de nitrogênio uréico no sangue de vacas de alta (AP) e média (MP) produção, no inverno (I) e no verão (V)

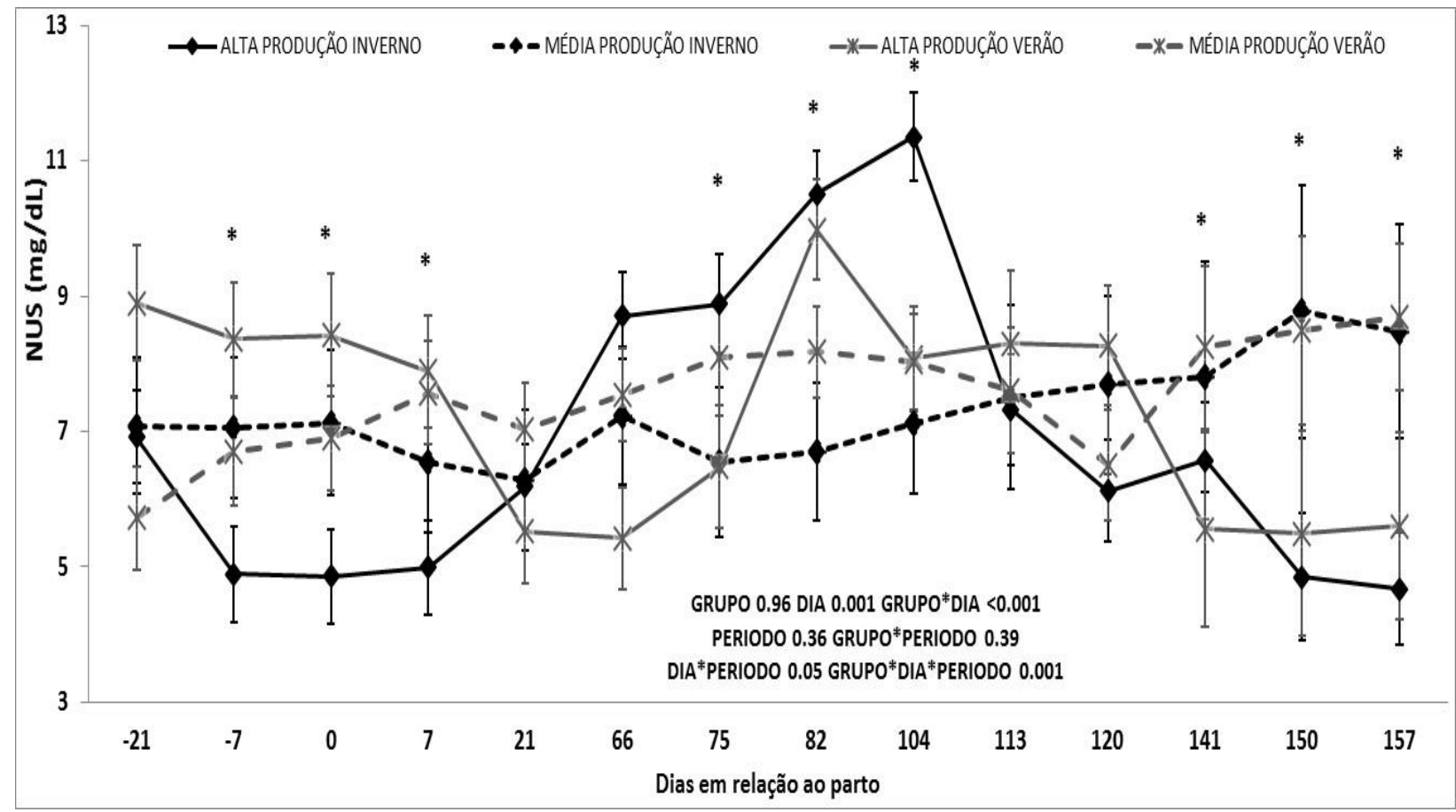

$* \mathrm{P}<0,05, * * \mathrm{P}=0,001, * * * \mathrm{P}<0,001$ para as comparações no período de transição e início da lactação. AP

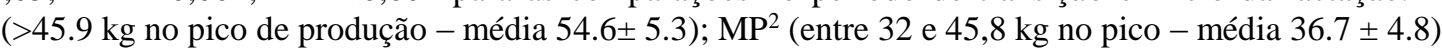

Figura 19B - Variação da concentração de nitrogênio uréico no sangue de vacas leiteiras prenhes à primeira IATF ou vazias aos 150 DEL no inverno (I) e no verão (V)

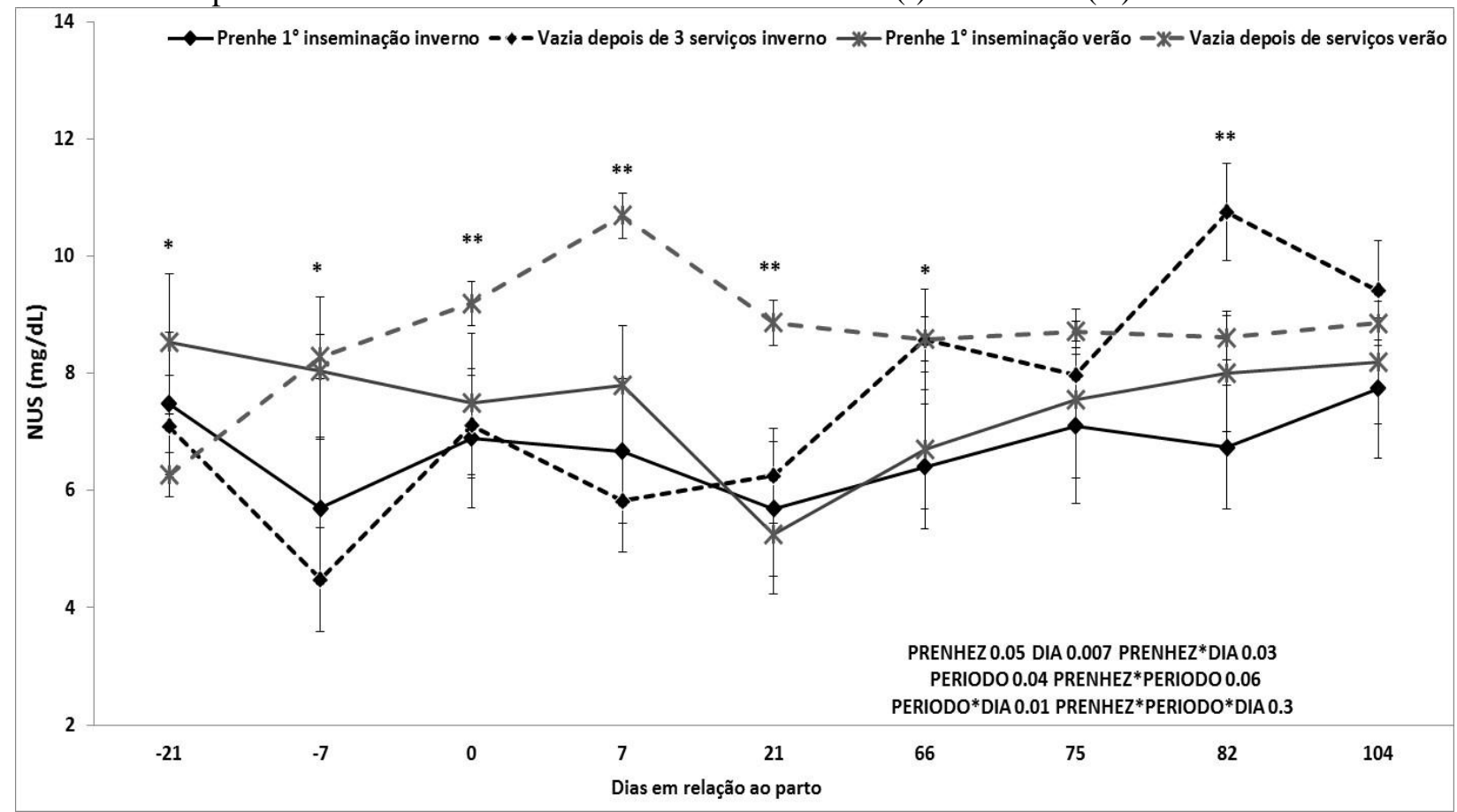

$* \mathrm{P}<0,05, * * \mathrm{P}=0,001, * * * \mathrm{P}<0,001$ para as comparações no período de transição e início da lactação. AP

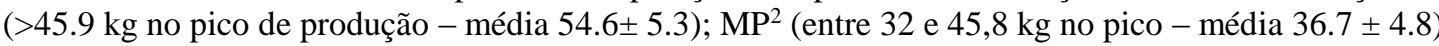


3.5.6 Conclusão do capitulo 1

As hipóteses gerais do presente estudo foram parcialmente comprovadas, pois, existem diferenças metabólicas entre vacas de mesma produção leiteira, na mesma estação do ano que podem afetar a fertilidade, tanto nas vacas leiteiras de alta, como nas de média produção, nos três primeiros serviços.

Os modelos animais utilizados no presente estudo, baseados em produção e fertilidade, foram eficientes para mostrar essas diferenças metabólicas ocorridas durante o período de transição e início de lactação.

As variações dos teores dos metabólitos avaliados são indicativas dos possíveis mecanismos que podem estar ligados às diferenças na produtividade leiteira e na fertilidade dos animais durante os primeiros 150 dias em lactação no inverno e no verão.

Portanto, os padrões de variações metabólicas durante o período de transição e inicio de lactação são determinados pela produtividade leiteira, mas, os teores e os padrões de variação metabólica são diferentes em cada período do ano, mesmo entre vacas leiteiras que ficam prenhes na primeira inseminação. 


\section{CAPÍTULO 2: AVALIAÇÃO E ESCOLHA DE VARIÁVEIS PREDITORAS DA INCIDÊNCIA DE DOENÇAS NO PERÍODO DE TRANSIÇÃO E INÍCIO DE LACTAÇÃO EM VACAS DE ALTA E MÉDIA PRODUÇÃO NO INVERNO E NO VERÃO}

\subsection{Justificativa e Hipótese}

As diferenças metabólicas são geradas principalmente pelo potencial genético da vaca leiteira, entretanto, as mudanças ambientais, como a estação do ano, aumentam as alterações fenotípicas entre vacas de alta e média produção, ou de vacas que tem melhor fertilidade. Essas alterações metabólicas, normalmente, geram um aumento na incidência de doenças durante período de transição. Estas doenças podem acarretar em perdas produtivas, infertilidade e aumento da chance da vaca ser descartada involuntariamente até os 150 dias em lactação.

Os transtornos de saúde (retenção de placenta, cetose, deslocamento de abomaso, metrite, mastite e problemas de casco) e de fertilidade podem ser explicados pela alteração dos padrões de variação metabólica no período de transição.

Compreender as variações de alguns parâmetros, pode auxiliar na prevenção de algumas doenças metabólicas durante o período de transição e inicio de lactação são diferentes em vacas de diferente produtividade leiteira, bem como nas estações do ano.

As Hipoteses gerais do presente capítulo são:

1) A alta produção leiteira é um fator de risco para aumentar a incidência de doenças puerperais;

2) O verão é um fator de risco para aumentar a incidência de doenças puerperais e a taxa de descarte;

3) A ocorrência de doenças puerperais é menor em vacas que ficam prenhes na primeira inseminação artificial, independente da estação do ano;

4) Em ambos períodos do ano, as principais variáveis preditoras de doenças puerperais, são aquelas ligadas ao metabolismo energético, como: glicose, AGNE e BHBA. 


\subsection{Objetivos}

O presente capítulo tem como objetivo avaliar a incidência de doenças em vacas leiteiras, baseado no modelo de produção ou de fertilidade (como descrito anteriormente no capítulo 3), durante os primeiros 150 dias de lactação no inverno e no verão. Além disso, visa elucidar as interações entre variáveis metabólicas que podem servir como preditoras de doenças;

\subsection{Objetivos Específicos}

Como objetivos específicos, este capítulo visa:

1) Compreender as relações entre o metabolismo protéico, energético e hepático sobre a incidência de doenças em vacas leiteiras;

2) Indicar quais variáveis são preditoras da saúde de vacas leiteiras no inverno e no verão;

3) Verificar a incidência de doenças puerperais em vacas leiteiras, baseado nos modelos de produção ou de fertilidade acordo com a produtividade leiteira;

4) Verificar quais fatores de rebanhos são importantes na predição de doenças;

5) Verificar se é eficiente utilizar o dia 21 que antecede o parto como um ponto de coleta para a predição de doenças pueperais em vacas leiteiras.

\subsection{Materiais e Métodos}

O manejo dos animais no experimento, foi dividido em duas fases, assim como descrito no tópico 3.4 do capitulo 1. 
4.4.1 Produção e composição do leite

Todas as vacas utilizadas no experimento foram ordenhadas três vezes por dia. Para a análise de dados foi feita uma média semanal da produção. As coletas de leite para análises de gordura, proteína, lactose e células somáticas foram realizadas quinzenalmente. A produção de leite foi corrigida para 3,5\% de gordura para posterior avaliação, segundo fórmula descrita por Sklan et al. (1992), onde PLC $=(0,432+0,1625 *$ teor de gordura do leite $) * \mathrm{~kg}$ de leite.

As amostras foram acondicionadas em frascos plásticos com conservante (Bronopol ${ }^{\circledR}$ ), mantidas entre 2 e $6^{\circ} \mathrm{C}$, até a realização das análises, em no máximo 72 horas. As análises de composição do leite foram realizadas por absorção infravermelha na Clínica do Leite na ESALQ/USP. Os dados de produção e composição do leite foram utilizados no modelo de predição de doenças. As mudanças dessas variáveis ao longo do experimento não são objetivo de discussão do presente estudo.

4.4.2 Avaliação de desordens uterinas

A avaliação clínica para avaliação de metrite foi realizada aos $10 \pm 3$ dias pós-parto e a

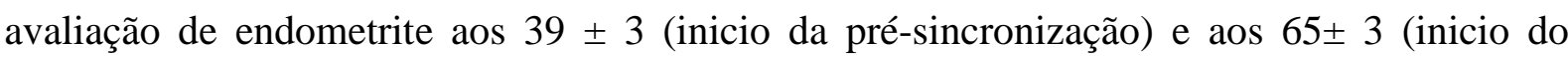
protocolo de IATF) de palpação retal e ultrassonografia.

$\mathrm{Na}$ avaliação uterina, avaliava-se: posicionionamento (pélvico ou abdominal); tamanho, simetria e consistência. Era feito uma massagem dos cornos uterinos para verificar a presença de muco, quando havia, era classificado quanto ao aspecto. 0 - sem muco; 1) muco limpo; 2) muco com poucas estrias de pús; 2) muco com pelo menos $25 \%$ de estrias de pus; 3) muco com 50\% de pús; 4) Muco purulento; 5) muco sero sanguinolento. A classificação 5 era utilizada somente na avaliação de metrite. Vacas com condição 3 de muco já eram consideradas com endometrite.

Aos 39 dias após o parto e também no incio do protocolo de IATF era avaliada ciclicidade dos animais, com um ultrassom da marca mindray®, modelo DP 2200 vet. Portanto, os animais que não tiveram o diagnóstico de endometrite após a palpação retal, foram submetidos a um exame ultrasonográfico do trato reprodutivo. Neste exame avaliaramse a presença de conteúdo ecogênico na base dos cornos ou na cervix. 


\subsubsection{Analises estatísticas}

As informações individuais das vacas foramm dispostas em uma única planilha, para a realização das análises estatísticas.

As análises estatísticas foram realizadas utilizando o programa SAS versão 9.3 (SAS / STAT ®, SAS Inst. Inc., Cary, NC, 2012). Os modelos estatísticos utilizados para avaliar esses dados, seguem os critérios adotados para avaliar as variáveis metabólicas, conforme descrito no item 3.4.3 do capitulo 1 .

As variáveis: escore de condição corporal (ECC), escore de claudicação (ECLAU), foram avaliados utilizando a matriz AIC para modelos mistos de medidas do PROC MIXED (SAS, 2012). Ao avaliar essas variáveis foram considerados os efeitos grupo de produção ou grupo de prenhez, período do ano, dias (pontos de coleta), e as interações duplas e triplas entre estes fatores.

Para todas as variáveis foram realizadas análises de homogeneidade das variâncias e normalidade dos resíduos (Shapiro-Wilk). Todos os out-liers foram excluídos ou transformados, quando necessário, antes dos dados serem submetidos a analise de regressão logística (Proc Logistic, SAS versão 9.3, 2012).

$\mathrm{Na}$ analise de regressão logística, foram incluídos todos os fatores metabólicos, produtivos e de rebanho (que foram usados para selecionar as vacas para entrar no experimento), para produzir, a partir desse conjunto de observações o modelo estatístico, aliado aos modelos animais de grupo de produção ou de fertilidade, de predição de valores binários, ligados a incidência de doenças. Nos modelos tomados e usados no Proc Logistic, foi utilizada a categorização das variáveis continuas para explicar as diferenças na frequiência das variáveis binárias.

Os dados foram analisados por regressão logística multivariada, usando o modelo "backward stepwise regression" e as variáveis explanatórias foram sequencialmente removidas do modelo estatístico, seguindo o critério de wald, onde: P> 0,10, excluí-se do modelo. Valores de $\mathrm{P}<0,05$ são considerados significantes.

Os dados são expressos como média como uma medida da tendência central, e o erro padrão da média como medida de dispersão. O nível de significância utilizado para rejeitar a hipótese H0 (hipótese nula) para todos os dados obtidos foi $\mathrm{P}<0,05$ e tendências estatísticas como $\mathrm{P}<0,10$ foi considerado. 


\subsection{Resultados}

Não houve interações entre grupo de produção e estação do ano $(\mathrm{P}>0,05)$, mas houve efeito isolado desses fatores $(\mathrm{P}<0,05)$ na incidência de doenças puerperias e nos modelos de predição de doenças nas vacas do presente estudo. Portanto, na tabela 5A serão apresentadas as frequiências das doenças de acordo com a produção leiteira ou de acordo com a estação do ano. No modelo animal, baseado na fertilidade, foi observado interação entre grupo e estação do ano $(\mathrm{P}<0,05)$, portanto, na tabela 5B serão apresentadas as frequências de cada grupo em cada período.

4.5.1 Incidência e fatores predisponentes na ocorrência de doenças puerperais

Não foi observada nenhuma diferença na incidência de doenças entre as vacas de alta ou média produção leiteira, ou nos períodos do inverno ou do verão ( $\mathrm{P}>0,05)$. De acordo com os grupos experimentais, houve somente tendência para a incidência de retenção de placenta $(\mathrm{P}=0,09)$, metrite $(\mathrm{P}=0,07)$. Avaliando a incidencia de doença nos períodos, foram observadas tendências de efeito para antecipação do parto $(\mathrm{P}=0,1)$, peso da cria $(\mathrm{P}=0,07)$, metrite $(\mathrm{P}=0,08)$, conforme tabela 5A.

Foram observadas de acordo com os grupos de prenhez, diferenças na nas variáveis: antecipação do parto $(\mathrm{P}=0,03)$, auxilio parto $(\mathrm{P}=0,05)$, retenção de placenta $(\mathrm{P}=0,009)$, metrite $(\mathrm{P}=0,04)$ e tendências de efeito nas variáveis peso da cria $(\mathrm{P}=0,07)$, deslocamento de abomaso $(\mathrm{P}=0,06)$, cetose $(\mathrm{P}=0,08)$ e endometrite $(\mathrm{P}=0,08)$, conforme tabela $5 \mathrm{~B}$.

Houve uma antecipação média do parto de 5,5 dias no verão, sendo que nas vacas que ficaram vazias após 3 serviços, a essa antecipação foi em média 11 dias, o que parto levou a um aumento de 3,8 vezes $(\mathrm{P}<0,001)$ na razão de chances para taxa de auxilio ao parto. Analisando os possíveis fatores predisponentes a estes dois eventos, são significativos no modelo de predição, os fatores descritos na tabela 6 .

Dos fatores metabólicos avaliados no $\mathrm{D}-21$, foram importantes preditores $(\mathrm{P}<0,05)$ da ocorrencia da ocorrência de doenças no período de transição: teores plasmáticos de AST acima de $90 \mathrm{U} / \mathrm{L}$, glicose abaixo de 52,4 mg/dL, AGNE acima de 0,4 mmol/L, BHBA acima de $0,7 \mathrm{mmol} / \mathrm{L}$ e SOD abaixo de 3037,6 U/g Hb, conforme tabela 7. 
Essa antecipação do parto no período do verão foi também um dos fatores de risco para o aumento da razão de chances em 6,74 vezes $(\mathrm{P}=0,001)$ da ocorrência de retenção de placenta nas vacas que não ficaram prenhes no verão e em 4,8 vezes $(\mathrm{P}=0,003)$ nas vacas que não ficaram prenhes no inverno.

Dos fatores predisponentes para a ocorrência de retenção de placenta, foram importantes no modelo (Tabela 8): condição corporal acima de 3,25 no dia 21 antes do parto; numero de lactações, sendo as vacas de segunda lactação as mais predispostas; intervalos entre partos $\geq$ 420 dias; antecipação do parto em mais de 7 dias, conforme tabela 8. Dos fatores metabólicos avaliados como fatores de risco no dia 21 antes do parto, destacaram-se: teores plasmáticos de glicose acima de $107 \mathrm{mg} / \mathrm{dL}$; NUS acima de 19,9 mg/dL; AGNE acima de 0,4 mmol/L e BHBA >0,7 mmol/L, conforme tabela 9.

A incidência de metrite foi maior nas vacas vazias em ambos os períodos estudados e também nas vacas de média produção (Tabela 5A). Entretanto, avaliando isoladamente os períodos, foi verificado um aumento dos casos principalmente no verão. Portanto, os fatores de risco para o aumento da razão de chances $(\mathrm{P}<0,05)$ foram: parto no verão; escore de claudicação maior que 2 no período pré parto; Numero de crias (aumento nas vacas com 3 ou mais crias); intervalo entre partos acima de 420 dias; a vaca ter sido repetidora de cio (>4 inseminações até a concepção) na lactação anterior; partos gemelares, conforme tabela 10. Destes fatores, correlacionaram-se $\left(\mathrm{R}^{2}=0,86 ; \mathrm{P}=0,03\right)$ o escore de claudicação com o numero de crias.

Dos fatores metabólicos medidos no D21, foram importantes no modelo de predição de metrite, baixos teores de GGT e CK, associados a alta glicose e nitrogênio uréico no sangue, conforme tabela 11.

Tanto a incidência de retenção de placenta como a de metrite foram maiores $(\mathrm{P}<0,05)$ nas vacas que ficaram vazias depois de 3 serviços, independente da estação do ano.

Houve uma tendência $(\mathrm{P}=0,08)$ de aumento de endometrite nas vacas que não ficaram prenhes depois de 3 serviços, independente da estação do ano (Tabela 5B). Embora a relação metrite: endometrite tenha sido maior de acordo com o modelo animal de grupo de produção (0,9 AP e 1,1 MP) ou de acordo com a estação do ano (0,9 I e 1,0 V), parece que as vacas que ficam vazias depois de três serviços, desenvolvem problemas ou talvez haja uma persistencia dos problemas uterinos por mais tempo (caracterizado por diminuição na relação metrite: endometrite), gerando um impacto maior sobre a fertilidade.

Não houve diferenças significativas $(\mathrm{P}>0,05)$ na ocorrência de casos de deslocamento de abomaso entre os grupos de produção, ou apenas quando foi avaliado somente o efeito de 
Capítulo 2 - Avaliação e escolha de variáveis preditoras da incidência de doenças

estação do ano. As vacas que ficaram vazias no período do verão tiveram maior incidência de deslocamento de abomaso em relação aos outros grupos, entretanto, foi apenas uma tendência de efeito $(\mathrm{P}=0,06)$ tanto para esta afecção, como para a incidência de cetose.

Tabela 4A - Incidência de doenças e fatores ligados ao parto em vacas holandesas de alta produção (AP) e vacas de média produção (MP), no inverno (I) e no verão $(\mathrm{V})$

\begin{tabular}{|c|c|c|c|c|c|c|}
\hline \multirow[b]{2}{*}{ Variáveis } & \multicolumn{2}{|c|}{$\begin{array}{c}\text { Grupos } \\
\text { Experimentais } \\
\end{array}$} & \multirow[b]{2}{*}{ Valor de P } & \multicolumn{2}{|c|}{ Período Experimental } & \multirow[b]{2}{*}{ Valor de $\mathrm{P}$} \\
\hline & $\begin{array}{c}\mathrm{AP}^{1} \\
(\mathrm{n}=130)\end{array}$ & $\begin{array}{c}\mathrm{MP}^{2} \\
(\mathrm{n}=125)\end{array}$ & & $\begin{array}{l}\text { Inverno }^{3} \\
(n=111)\end{array}$ & $\begin{array}{l}\text { Verão }^{4} \\
(\mathrm{n}=134)\end{array}$ & \\
\hline Antecipação do parto, dias & -4.0 & -3.5 & 0.34 & -2.0 & -5.5 & 0.1 \\
\hline Auxilio parto, $\%$ & 11.3 & 14.7 & 0.22 & 11.1 & 15.0 & 0.2 \\
\hline Peso da cria, Kg & 39.1 & 38.4 & 0.3 & 40.4 & 37.0 & 0.07 \\
\hline Natimortalidade, \% & 9.8 & 9.6 & 0.37 & 8.3 & 11.1 & 0.13 \\
\hline Retenção de placenta, \% & 19.0 & 23.5 & 0.09 & 20.1 & 22.4 & 0.32 \\
\hline Metrite, $\%$ & 10.0 & 16.9 & 0.08 & 10.0 & 16.4 & 0.1 \\
\hline $\begin{array}{c}\text { Deslocamento de abomaso, } \\
\%\end{array}$ & 6.0 & 6.0 & 1 & 4.6 & 7.4 & 0.62 \\
\hline Cetose, $\%$ & 18.8 & 15.6 & 0.35 & 19.5 & 15.0 & 0.32 \\
\hline Endometrite, \% & 18.7 & 15.7 & 0.15 & 17.9 & 16.5 & 0.56 \\
\hline Relação metrite:endometrite & 0.9 & 1.1 & 0.9 & 0.9 & 1.0 & 0.4 \\
\hline
\end{tabular}

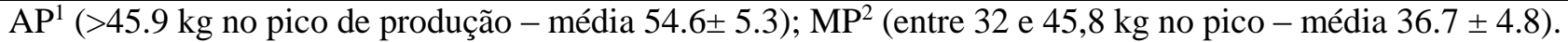

Tabela 4B - Incidência de doenças e fatores ligados ao parto em vacas holandesas prenhes à primeira IATF ou vazias aos 150 DEL no inverno (I) e no verão (V)

\begin{tabular}{cccccc}
\hline & \multicolumn{4}{c}{ Grupos experimentais } & \\
\cline { 2 - 4 } Variáveis & $\mathrm{PPII}^{1}(\mathrm{n}=28)$ & $\mathrm{VI}^{2}(\mathrm{n}=40)$ & $\mathrm{PPIV}^{3}(\mathrm{n}=38)$ & $\mathrm{VV}^{4}(\mathrm{n}=33)$ & Valor de P \\
\hline Antecipação do parto, dias & $-3.0 \mathbf{b}$ & $-1.9 \mathbf{c}$ & $-3.8 \mathbf{b}$ & $-11.0 \mathbf{a}$ & 0.03 \\
Auxilio parto, \% & $14.3 \mathbf{c}$ & $35.0 \mathbf{a}$ & $21.1 \mathbf{b}$ & $33.0 \mathbf{a}$ & 0.05 \\
Peso da cria, Kg & 39.9 & 42.1 & 37.2 & 38.3 & 0.07 \\
Natimortalidade, \% & 10.7 & 12.5 & 13.1 & 15.5 & 0.3 \\
Retenção de placenta, \% & $16.6 \mathbf{b}$ & $23.5 \mathbf{b}$ & $21.4 \mathbf{b}$ & $30.3^{\mathbf{a}}$ & 0.009 \\
Metrite, \% & $14.3 \mathbf{b}$ & $25.0 \mathbf{a}$ & $18.4 \mathbf{b}$ & $24.2^{\mathbf{a}}$ & 0.04 \\
Deslocamento de abomaso, \% & 0 & 5 & 5.2 & 9.1 & 0.06 \\
Cetose, \% & 21.4 & 30.0 & 21.1 & 30.3 & 0.08 \\
Endometrite, \% & 21.4 & 30.0 & 23.7 & 30.3 & 0.08 \\
Relação metrite:endometrite & 0.7 & 0.8 & 0.8 & 0.8 & 0.9 \\
\hline
\end{tabular}

PPII $^{1}$ (Vaca prenhe na primeira inseminação no inverno), VI $^{2}$ (Vacas vazias após três serviços no inverno), PPIV $^{3}$

(Vaca prenhe na primeira inseminação no verão) $\mathrm{VV}^{4}$ (Vacas vazias após três serviços no verão) 
Em estudo realizado por Ospina et al. (2010), avaliando mais de 1300 animais no período de transição, foram estabelecidos limites críticos nas concentrações de AGNE e BHBA, com relação a riscos para doenças metabólicas no pós-parto (deslocamento de abomaso, cetose clínica, metrite e retenção de placenta). Os valores críticos estabelecidos por estes autores para variáveis ligadas a metabolização foram iguais aos valores de corte do presente estudo, de $\geq 0,3 \mathrm{mmol} / \mathrm{L}$ para AGNE, entretanto, as coletas foram realizadas no dia 14 antes do parto e $\geq 0,96 \mathrm{mmol} / \mathrm{L}$ para BHBA no pós-parto $(+3 \mathrm{a}+14$ dias em relação ao parto). Tendo em vista a semelhança na eficiência de predição de ocorrência de doenças metabólicas tanto para grupos de produção ou de fertilidade no inverno e no verão, o dia 21 antes do parto pode ser usado como um ponto estratégico no monitoramento metabólico de rebanhos de vacas leiteiras, pois, normalmente é o ponto onde as vacas são trocadas de galpão ou reagrupadas.

De acordo com Smith (2006), no inicio do período pós-parto, devido a supressão imune, juntamente com altos teores plasmáticos de cortisol que ocorre principalmente em vacas de alta produção, pode antecipar o parto e causar distocias. Alguns estudos mostrasm que o útero normalmente é contaminado por uma grande variedade de microorganismos, mas a correta involução dependente do equilíbrio entre o crescimento bacteriano e os mecanismos de defesa do animal (SHELDON et al., 2004). Sendo que endotoxinas bacterianas nesses casos estimulam o sistema imunológico ativando a liberação de citocinas como as interleucinas que por sua vez estimulam o fígado a secretar proteínas de fase aguda (SHELDON et al., 2001; BEUTLER et al., 2003).

Quando isso ocorre, um aumento da atividade de algumas enzimas hepáticas como a GGT pode acontecer (REAHAGE et al., 1996). No presente estudo foi observado maiores teores dessa enzima no período pré-parto, e um aumento da atividade nas primeiras semanas de lactação nas vacas que anteciparam o parto, nas que tiveram retenção, nas vacas que tiveram metrite e endometrite.

Outro importante metabólito ligado a predição de doenças no presente estudo foi o NUS. As vacas que tiveram mais problemas de distocia e que desenvolveram infecções uterinas, foram aquelas tiveram maiores teores plasmáticos deste metabólito no pré parto ou um aumento acima de $13,3 \mathrm{mg} / \mathrm{dL}$ na primeira semana pós-parto, respectivamente. Jorristma et al. (2003) verificaram que vacas que tinham teores acima de $15,4 \mathrm{mgl} / \mathrm{dL}$ de NUS durante o período de transição, tiveram mais problemas uterinos e queda da fertilidade no primeiro serviço. Gonzalez (1997) também apontou o aumento dos níveis séricos de uréia como um fator negativo sobre a fertilidade. Além disso, de acordo com Butler (2003), altos teores de 
Capítulo 2 - Avaliação e escolha de variáveis preditoras da incidência de doenças

uréia no plasma geram alterações iônicas nas secreções uterinas, o que pode afetar os mecanismos de defesa local. Entretanto, Kaufmann et al. (2008) demonstraram que vacas multíparas com endometrite, apresentaram uma diminuição do valor de uréia quando comparado com vacas sadias.

Dietas com maiores teores protéicos no período de transição, como as dietas de inicio de lactação do presente estudo, podem ocasionar um umento dos níveis de uréia no rúmen e na circulação. Gonzalez (1997); Jorritsma et al. (2003) e Lacetera et al. (2005) provaram que níveis altos de uréia causariam problemas na fertilidade e na saúde de vacas leiteiras. Neste estudo compararam-se animais de diferentes produtividades leiteira em diferentes estações do ano, bem como as vacas mais férteis comparadas as vacas de menor fertilidade. As diferenças nos teores plasmáticos e no padrão de variação deste metabólito, corroboram com os achados dos três estudos citados. Além desses, no estudo de Henriques (2011), foi verficado também que vacas com infecções uterinas apresentavam níveis de uréia maiores do que os animais sadios. Portanto, pode-se inferir que o aumento de níveis de uréia poderia propiciar aumento de processos infecciosos no útero. O que vai de acordo com Butler (2000) que relatou que vacas com infecção uterina no inicio do pós parto, os teores de NUS são mais elevados e isso gera uma alteração de $\mathrm{pH}$ no interior do útero. Estudando mais afundo, alguns autores, verificaram que o aumento de níveis séricos de uréia teve um impacto negativo sob a função dos polimorfonucleares no meio uterino (ELROD; BUTLER, 1993; HOEBEN; HEYNEMANN; BURVENICH, 1997; BUTLER 1998; HOEBEN, 2000; RHOADS et al., 2004; HAMMON et al., 2006; HENRIQUES, 2011). Já os resultados obtidos por Kaufmann et al. (2008) não estão de acordo com os encontrados nesta pesquisa e com os resultados de Henriques (2011), pois para eles, valores diminuídos de uréia estariam relacionados com a presença de infecções uterinas.

Ainda comparando os resultados do presente estudo com os dados de Henriques (2011), foi verificada uma semelhança nos teores de proteína total entre as vacas com problemas uterinos e as vacas que não ficaram doentes. No estudo citado, também houve diferença estatística nos teores e no padrão de variação de uréia nas vacas com infecção uterina $(27,83 \pm$ $9,85 \mathrm{mg} / \mathrm{dL})$ ou não $(40,33 \pm 13,28 \mathrm{mg} / \mathrm{dL})$.

Em outro trabalho brasileiro, voltado a determinação de parâmetros bioquímicos de parâmetros de vacas leiteiras com afecções puerperais, Gregory (1995) encontrou valores de albumina em torno de $35,3 \pm 0,46 \mathrm{mg} / \mathrm{dL}$ parecidos com o do presente estudo e também dos valores propostos por Radostitis (2000) e Kaneko (2009), sendo 30,3 a 35,5 mg/dL e de 21,0 a $36,0 \mathrm{mg} / \mathrm{dL}$, respectivamente. Entretanto no estudo de Gregory (1995), as vacas utilizadas 
eram da raça Jersey. Os valores encontrados no presente estudo, no estudo de Gregory (1995) e Henriques (2011) são superiores aos valores este superior ao sugerido por Gonzalez (1997) para animais propensos a desenvolver infecções uterinas.

Diferente do trabalho de Henriques (2011) e assim como encontrado no presente estudo, Souza (2005) também encontrou um efeito significativo nos padrões de variação de albumina em vacas férteis no primeiro serviço, comparadas a vacas com infecções uterinas $(3,22 \pm 0,30$ $\mathrm{g} / \mathrm{dL}$ e $2,79 \pm 0,36 \mathrm{~g} / \mathrm{dL}$, respectivamente).

Portanto no que diz respeito as mudanças no metabolismo protéico e no teor plasmático de enzimas hepáticas (que serão discutidas mais adiante), devido a infecções uterinas, duas hipóteses podem ser levantadas: Vacas leiteiras que desenvolvem infecções uterinas estão menos propensas a ficarem prenhes nos três primeiros serviços, pois normalmente desenvolvem uma insuficiência hepática crônica no inicio de lactação. O que vai de acordo também com o estudo de Henriques (2011), que verificou que a insuficiência hepática de vacas com infecções uterinas, na verdade são uma consequiência de um processo endotóxico causado pelas bactérias que estão presentes no útero de vacas imunosuprimidas, que tem como caracteristica hipoalbuminemia. Outra hipótese, que também concorda com o estudo citado é a de que a hipoalbuminemia estaria ligada a diminuição no carreamento de colesterol para ser convertido em hormônios esteróides que regulam a atividade folicular, uterina e comportamental das vacas.

Baixas concentrações de glicose (por volta de $45 \mathrm{mg} / \mathrm{dL}$ ), aliadas a altas concentrações de $\operatorname{AGNE}(>0,4 \mathrm{mmol} / \mathrm{L})$ no pré-parto, foram características das vacas que tiveram distocia, retenção de placenta e metrite no presente estudo. No estudo de estudo Rukkwamsuk et al. (1999); Könyves et al. (2008) e Henriques (2011) também foi verificada a mesma condição em vacas que desenvolviam endometrites. Corroborando também com os resultados apresentados no presente estudo, Jorristma et al. (2004) também observaram um aumento de problemas uterinos em vacas com teores de $\operatorname{AGNE~(>0,4~mmol/L),~além~disso,~essas~vacas~}$ tiveram uma redução da fertilidade.

Nem todas as vacas que desenvolveram cetose durante o período de transição, no presente estudo, tiveram baixas concentrações plasmáticas de glicose, mas todas tiveram altas concentrações de AGNE e BHBA no soro. Além disso, as variações nos teores das enzimas hepáticas foram diferentes entre estas vacas. Não houve um padrão nos teores das enzimas AST e GGT nas vacas que desenvolveram cetose, o que pode estar ligado a diferentes graus de esteatose hepática nesses animais. Alguns estudos tem mostrado uma correlação positiva 
entre a concentração dos corpos cetônicos no sangue e o grau de esteatose hepática e negativa com o teor de glicogênio no fígado (CARSON et al., 2008).

Além disso, os teores de AGNE e BHBA, foram fatores determinantes na ocorrência de doenças uterinas no presente experimento, que está de acordo com LeBlanc (2010), que relatou que quando a liberação da placenta não ocorre adequadamente e a involução uterina é tardia, normalmente, está ligado a supressão imune prolongada. Esta supressão imune pode levar a um aumento de infecções uterinas no inicio do período pós-parto (SHELDON et al., 2004). Os teores de 0,4 e $0,7 \mathrm{mmol} / \mathrm{L}$ para AGNE e BHBA em vacas com problemas uterinos, são semelhantes aos valores encontrados por Kaufmann et al. (2008) e Henriques (2011).

Em relação aos teores séricos de AST pode se observar que as vacas que desenvolveram problemas uterinos, tinham altos teores dessa enzima, achado semelhante ao do estudo de Henriques (2011), entretanto, os teores médios de AST para as vacas que desenvolveram infecção uterina do estudo citado foram metade $(44,85 \mathrm{U} / \mathrm{L})$ dos valores encontrados nas vacas doentes do presente estudo. Como o objetivo do estudo citado era estudar as variações metabólicas em vacas que desenvolveram diferentes graus de endometrite, provavelmente a média geral desse modelo animal não tenha elucidado bem essas diferenças, pois o limite inferior dos intervalos de confiança do grupo sadio (49,08 U/L) era maior do do que o limite superior do grupo com infecção moderada (37,13 U/L).

Corroborando com os achados do presente estudo, Martin et al. (2008) relatam que o aumento de AST no período puerperal recente esta relacionado com o desenvolvimento de doenças uterinas, e calcularam o ponto de corte, para a predição a partir desta enzima, sendo: para a primeira semana o valor foi $78 \mathrm{U} / \mathrm{L}$ e para a segunda semana foi 75,9 U/L, que estão acima dos teores encontrados por Henriques (2011) (44,85 U/L) e por Souza (2005), $37,61 \pm 7,30 \mathrm{U} / \mathrm{L}$. Entretanto, foram inferiores ao ponto de corte do presente estudo (90 U/L), embora a metodologia laboratorial tenha sido a mesma para os estudos citados. Estas diferenças são explicadas principalmente por três fatores: 1) Produtividade leiteira das vacas, onde, as vacas do presente estudo e no estudo de Martin et al. (2008) era maior; 2) Dieta dos animais, onde, no presente estudo e no estudo de Martin et al. (2008), os teores de proteína e lipídios eram semelhantes. Enquanto, que não há uma descrição do conteúdo das dietas nas vacas dos outros dois estudos, que foram realizados em várias fazendas; 3) Pelo presente estudo ter sido realizado em diferentes estações do ano.

Para os teores séricos de GGT não foram encontradas diferenças estatísticas entre os grupos de produção no presente estudo, mas esta enzima medida no D21 que antecede o parto pode ser utilizada como preditora da ocorrência de doenças puerperais. 
No presente estudo, as vacas vazias em ambos os períodos, tiveram índices de cetose, metrite e endometrites maiores que as vacas que emprenharam no primeiro serviço. No estudo de Rehage et al. (1996) também foi verificada uma relação positiva entre esteatose e infecções uterinas.

O índice de deslocamento de abomaso foi maior para as vacas que ficaram vazias no verão, isso pode ser explicado pelo aumento de casos de cetose e infecções nesse período, o que provavelmente resultou em períodos maiores de anorexia e inapetência.

No modelo de predição desta afecção, os teores sanguíneos de AST e BHBA, foram de grande relevância, que corrobora com o estudo de Geishauser et al. (1997a). Os valores de referencia de AST foram parecidos com os teores encontrados no presente estudo (entre 100$180 \mathrm{UI} / \mathrm{L}$ ), no entanto, os teores de BHBA foram mais elevados no estudo citado (entre 1,01,6 mmol/L). Posteriormente, no mesmo grupo de pesquisa, LeBlanc, Leslie e Duffield (2005) encontraram que valores aumentados de AGNE e BHBA aumentados $(>0,4 \mathrm{mmol} / \mathrm{L}$, duas semanas antes do parto) e (1,4 mmol/L na primeira semana de lactação), respectivamente aumentam de 2 a 4 vezes a razão de chances o risco de deslocamento de abomaso à esquerda.

O aumento da incidência de cetose tanto em vacas com D.A, como naquelas que não ficam prenhes no primeiro serviço tem sido relatado em vários estudos (LEBLANC et al., 2002a,b,c; LEBLANC et al., 2004; DUFIELD et al., 2005; LEBLANC, 2005; LEBLANC et al., 2005; CARSON, 2008; DUFIELD et al., 2009). Nas vacas que ficaram vazias após três serviços, bem como no modelo de predição de D.A, foi verificado que um estado hiperglicêmico no período de transição e inicio de lactação, que provavelmente reflete um estado de resistência a insulina e a liberação mais intensa de glicocorticóides nesses tipos de vacas, respectivamente. De acordo com essa hipótese, Stariè et al. (2004) sugerem que a hiperglicemia, especialmente em animais com DA à direita, pode estar associada com o mau funcionamento pancreático devido ao prejuízo na saída do suco pancreático e distúrbio na circulação sanguínea no parênquima pancreático devido à mudança anatômica do duodeno e omento.

Foi verificado tanto nas vacas com cetose, como nas vacas com D.A altos teores de AST (por volta de $128 \mathrm{U} / \mathrm{L}$ ), que é bem parecido com os teores encontrados por Gruenberg et al. (2004), onde os valores de AST encontrados nas vacas com D.A foram por volta de 130 $\mathrm{UI} / \mathrm{L}$.

No presente estudo taxa média de ocorrência de D.A foi de $6 \%$, que é maior do que estes estudos canadenses utilizados na discussão dos dados $(2 \%$ em média nos estudos de GEISHASER et al.,1997b; LEBLANC et al., 2002a,b,c; LEBLANC et al., 2004; LEBLANC, 
2005; DUFIELD et al., 2005; LEBLANC et al., 2005; CARSON, 2008; DUFIELD et al., 2009). Entretanto esta incidência, reflete apenas 10 a $15 \%$ da realidade das fazendas brasileiras que possuem tecnificação semelhantes a do presente estudo. Portanto, mais estudos epidemiológicos necessitam ser realizados para elucidar a incidência e os fatores envolvidos em cada região do país, para que estratégias eficientes de manejo possam ser desenvolvidas.

4.5.2 Fatores preditores da taxa de auxilio ao parto e retenção de placenta

Tabela 5 - Razão de chances da estimativa e intervalo de confiança do perfil máximo de verossimilhança para taxa de auxilio ao parto, em vacas holandesas de alta produção (AP) e de média produção (MP), no inverno (I) e no verão (V), com base em eventos durante o período de transição

\begin{tabular}{|c|c|c|c|c|c|c|c|c|}
\hline Variável & Unidade & Efeito & Média & $\begin{array}{c}\text { Taxa } \\
(\%)\end{array}$ & Estimativa & \multicolumn{2}{|c|}{$\begin{array}{c}95 \% \text { Limites de } \\
\text { confiança }\end{array}$} & $\begin{array}{c}\text { Valor de } \\
\text { P }\end{array}$ \\
\hline \multirow[t]{2}{*}{ Período } & - & Inverno & - & 11.1 & 1.021 & 0.601 & 1.498 & $<.0001$ \\
\hline & - & Verão & - & 15 & Referente & - & - & - \\
\hline \multirow[t]{2}{*}{ ECC } & \multirow{2}{*}{0.25} & $2.5-3.0$ & 2.65 & 25.2 & 0.694 & 0.536 & 0.898 & 0.0055 \\
\hline & & $3.25-4.25$ & 3.45 & 14.6 & Referente & - & - & - \\
\hline \multirow{2}{*}{$\begin{array}{l}\text { Intervalo entre } \\
\text { partos }\end{array}$} & \multirow{2}{*}{ dias } & $290-360$ & 335 & 16.4 & 0.992 & 0.891 & 0.999 & $<.0001$ \\
\hline & & $370-550$ & 420 & 26.2 & Referente & - & - & - \\
\hline \multirow[t]{2}{*}{ Diferença Parto } & \multirow{2}{*}{ dias } & 5 a 9 & 7.8 & 29 & 1.004 & 1 & 1.009 & 0.0421 \\
\hline & & 2 a 4 & 2.9 & 12.6 & Referente & - & - & - \\
\hline \multirow[t]{2}{*}{$\begin{array}{l}\text { Número } \\
\text { Bezerro }\end{array}$} & \multirow{2}{*}{ Número } & 1 & - & 11.8 & 14.191 & 9.629 & 20.916 & $<.0001$ \\
\hline & & 2 & - & 28.2 & Referente & - & - & - \\
\hline
\end{tabular}

Tabela 6 - Razão de chances da estimativa e intervalo de confiança do perfil máximo de verossimilhança para taxa de auxilio ao parto, em vacas holandesas de alta produção (AP) e de média produção (MP), no inverno (I) e no verão (V), com base na mensuração de variáveis bioquímicas no dia -21 em relação ao parto

\begin{tabular}{|c|c|c|c|c|c|c|c|c|}
\hline \multirow{2}{*}{$\begin{array}{c}\text { Variável } \\
\text { AST }\end{array}$} & \multirow{2}{*}{$\begin{array}{c}\text { Unidade } \\
\text { U/L }\end{array}$} & \multirow{2}{*}{$\begin{array}{c}\text { Efeito } \\
100-160\end{array}$} & \multirow{2}{*}{$\begin{array}{c}\text { Média } \\
128.1\end{array}$} & \multirow{2}{*}{$\begin{array}{c}\text { Taxa }(\%) \\
20.6\end{array}$} & \multirow{2}{*}{$\begin{array}{c}\text { Estimativa } \\
2.992\end{array}$} & \multicolumn{2}{|c|}{$\begin{array}{l}\text { 95\% Limites de } \\
\text { confiança }\end{array}$} & \multirow{2}{*}{$\begin{array}{c}\begin{array}{c}\text { Valor de } \\
\text { P }\end{array} \\
<.0001\end{array}$} \\
\hline & & & & & & 0.989 & 3.996 & \\
\hline \multirow{3}{*}{ GLI } & \multirow{3}{*}{$\mathrm{mg} / \mathrm{dL}$} & $30-90$ & 65.6 & 13.3 & Referente & - & - & - \\
\hline & & $76-144$ & 107.6 & 13.5 & 0.997 & 0.964 & 1.009 & 0.0514 \\
\hline & & $35-75$ & 52.4 & 9.2 & Referente & - & - & - \\
\hline \multirow[t]{2}{*}{ BUN } & \multirow[t]{2}{*}{$\mathrm{mg} / \mathrm{dL}$} & $13-25$ & 19.9 & 15.1 & 1.06 & 1.033 & 1.088 & $<.0001$ \\
\hline & & $2.0-12$ & 4.7 & 7.8 & Referente & - & - & - \\
\hline \multirow[t]{2}{*}{ BHBA } & \multirow{2}{*}{$\mathrm{mmol} / \mathrm{L}$} & $1.2-2.4$ & 1.4 & 17.9 & 6.566 & 1.887 & 22.853 & 0.0031 \\
\hline & & $0.3-1.1$ & 0.7 & 10.6 & Referente & - & - & - \\
\hline \multirow[t]{2}{*}{ AGNE } & \multirow{2}{*}{$\mathrm{mmol} / \mathrm{L}$} & $0.9-1.6$ & 1.26 & 15.6 & 2.623 & 1.32 & 5.213 & 0.0059 \\
\hline & & $0.1-0.8$ & 0.4 & 9.3 & Referente & - & - & - \\
\hline \multirow[t]{2}{*}{ SOD } & \multirow{2}{*}{$\mathrm{U} / \mathrm{g} \mathrm{Hb}$} & $1800-3900$ & 3037.6 & 14.8 & 0.999 & 0.939 & 1.131 & $<.0001$ \\
\hline & & $4000-6000$ & 4391.6 & 8.8 & Referente & - & - & - \\
\hline
\end{tabular}


Tabela 7 - Razão de chances da estimativa e intervalo de confiança do perfil máximo de verossimilhança para incidência de retenção de placenta em vacas holandesas de alta produção (AP) e de média produção (MP), no inverno (I) e no verão (V), com base em eventos durante o período de transição.

\begin{tabular}{|c|c|c|c|c|c|c|c|c|}
\hline Variável & Unidade & Efeito & Média & $\begin{array}{c}\text { Taxa } \\
(\%)\end{array}$ & Estimativa & \multicolumn{2}{|c|}{$\begin{array}{l}\text { 95\% Limites de } \\
\text { confiança }\end{array}$} & $\begin{array}{c}\text { Valor de } \\
\mathrm{P}\end{array}$ \\
\hline \multirow[t]{2}{*}{ ECC } & \multirow{2}{*}{0.25} & $3.25-4.24$ & 3.45 & 23 & 0.72 & 0.544 & 0.95 & 0.0211 \\
\hline & & $2.5-3.0$ & 2.65 & 10 & Referente & - & - & - \\
\hline \multirow{2}{*}{$\begin{array}{l}\text { Intervalo entre } \\
\text { partos }\end{array}$} & \multirow{2}{*}{ dias } & $290-360$ & 335 & 12 & 1.004 & 1.002 & 1.006 & 0.0006 \\
\hline & & $370-550$ & 420 & 19 & Referente & - & - & - \\
\hline \multirow[t]{2}{*}{ Diferença Parto } & \multirow{2}{*}{ dias } & 5 to 9 & 7.8 & 27 & 1.014 & 1.006 & 1.028 & 0.0103 \\
\hline & & 2 to 4 & 2.9 & 12 & Referente & - & - & - \\
\hline
\end{tabular}

Tabela 8 - Razão de chances da estimativa e intervalo de confiança do perfil máximo de verossimilhança para incidência de retenção de placenta em vacas holandesas de alta produção (AP) e de média produção (MP), no inverno (I) e no verão $(\mathrm{V})$, com base na mensuração de variáveis bioquímicas no dia -21 em relação ao parto

\begin{tabular}{ccccccccc}
\hline \multirow{2}{*}{ Variável } & \multirow{2}{*}{ Unidade } & \multirow{2}{*}{ Efeito } & \multirow{2}{*}{ Média } & Taxa $(\%)$ & Estimativa & \multicolumn{2}{c}{ 95\% Limites de } & Valor de \\
confiança & P \\
\hline GLI & \multirow{2}{*}{$\mathrm{mg} / \mathrm{dL}$} & $76-144$ & 107.6 & 23.2 & 1.005 & 1.001 & 1.898 & 0.0057 \\
& & $35-75$ & 52.4 & 16.7 & Referente & - & - & - \\
BUN & \multirow{2}{*}{$\mathrm{mg} / \mathrm{dL}$} & $13-25$ & 19.9 & 23.4 & 0.962 & 0.933 & 0.991 & 0.0103 \\
& & & & & & & & - \\
& & $2.0-12$ & 4.7 & 18.3 & Referente & - & - & - \\
BHBA & \multirow{2}{*}{$\mathrm{mmol} / \mathrm{L}$} & $1.2-2.4$ & 1.4 & 24.6 & 4.58 & 1.823 & 6.467 & $<.0001$ \\
& & $0.3-1.1$ & 0.7 & 20.9 & Referente & - & - & - \\
AGNE & \multirow{2}{*}{$\mathrm{mmol} / \mathrm{L}$} & $0.9-1.6$ & 1.26 & 23.7 & 0.427 & 0.25 & 0.707 & 0.0013 \\
& & $0.1-0.8$ & 0.4 & 18.6 & Referente & - & - & - \\
\hline
\end{tabular}


4.5.3 Fatores preditores da ocorrência metrite e endometrite

Nas tabelas 10 e 11 estão os fatores e as estimativas, de fatores de rebanho e de fatores metabólicos, que explicam a incidência das doenças uterinas durante o período de transição e no ínicio do período de lactação em vacas de alta e média produção leiteira.

Tabela 9 - Razão de chances da estimativa e intervalo de confiança do perfil máximo de verossimilhança para incidência de metrite em vacas holandesas de alta produção (AP) e de média produção (MP), no inverno (I) e no verão $(\mathrm{V})$, com base em eventos durante o período de transição

\begin{tabular}{|c|c|c|c|c|c|c|c|c|}
\hline \multirow{2}{*}{$\begin{array}{c}\text { Variável } \\
\text { Grupo }\end{array}$} & \multirow{2}{*}{$\begin{array}{c}\text { Unidade } \\
-\end{array}$} & \multirow{2}{*}{$\begin{array}{c}\text { Efeito } \\
\text { Média Produção }\end{array}$} & \multirow{2}{*}{$\begin{array}{c}\text { Média } \\
34.8\end{array}$} & \multirow{2}{*}{$\begin{array}{c}\text { Taxa } \\
(\%) \\
16.9\end{array}$} & \multirow{2}{*}{$\begin{array}{c}\text { Estimativa } \\
1.701\end{array}$} & \multicolumn{2}{|c|}{$\begin{array}{l}\text { 95\% Limites } \\
\text { de confiança }\end{array}$} & \multirow{2}{*}{$\begin{array}{l}\begin{array}{l}\text { Valor } \\
\text { de P }\end{array} \\
0.06\end{array}$} \\
\hline & & & & & & 1.673 & 1.875 & \\
\hline & - & Alta Produção & 42.3 & 10 & Referente & - & - & - \\
\hline \multirow[t]{2}{*}{ Período } & - & Verão & - & 16.4 & 0.608 & 0.386 & 0.757 & 0.0317 \\
\hline & - & Inverno & - & 10 & Referente & - & - & - \\
\hline \multirow[t]{2}{*}{ ECLAU } & \multirow{2}{*}{1 to 5} & $\geq 3$ & 3.4 & 20.2 & 1.355 & 1.08 & 1.7 & 0.0086 \\
\hline & & $\leq 2$ & 1.54 & 10 & Referente & - & - & - \\
\hline \multirow[t]{2}{*}{ Lactação } & \multirow{2}{*}{ Número } & $3>5$ & 3.7 & 23.1 & 0.823 & 0.677 & 0.936 & 0.0496 \\
\hline & & 2 & 2 & 12 & Referente & - & - & - \\
\hline \multirow[t]{2}{*}{$\begin{array}{l}\text { Intervalo entre } \\
\text { partos }\end{array}$} & \multirow{2}{*}{ dias } & $290-360$ & 335 & 9.2 & 1.012 & 1.009 & 1.016 & $<.0001$ \\
\hline & & $370-550$ & 420 & 16.4 & Referente & - & - & - \\
\hline \multirow{3}{*}{$\begin{array}{c}\text { Serviços até } \\
\text { concepção na } \\
\text { lactação } \\
\text { anterior }\end{array}$} & \multirow[t]{3}{*}{ Número } & $4>6$ & 5.2 & 19.4 & 0.734 & 0.637 & 0.846 & \\
\hline & & & & & & & & $<.0001$ \\
\hline & & 1 to 3 & 2.3 & 13.5 & Referente & - & - & - \\
\hline \multirow[t]{2}{*}{$\begin{array}{l}\text { Número } \\
\text { Bezerro }\end{array}$} & \multirow{2}{*}{ Número } & 1 & - & 17.7 & 2.148 & 1.002 & 4.605 & 0.0495 \\
\hline & & 2 & - & 10.8 & Referente & - & - & - \\
\hline \multirow[t]{2}{*}{ Bezerro Peso } & \multirow{2}{*}{$\mathrm{kg}$} & $>40$ & 45.9 & 18 & 0.876 & 0.839 & 0.915 & $<.0001$ \\
\hline & & $35-40$ & 36.4 & 10.6 & Referente & - & - & - \\
\hline \multirow[t]{2}{*}{$\begin{array}{l}\text { Gordura do } \\
\text { leite }\end{array}$} & \multirow[t]{2}{*}{$\begin{array}{l}\% \text { aos } 14 \\
\text { DEL }\end{array}$} & $\leq 3.5$ & 3.2 & 16.6 & 0.386 & 0.155 & 0.961 & 0.0407 \\
\hline & & $\geq 3.5$ & 3.7 & 9.2 & Referente & - & - & - \\
\hline \multirow[t]{2}{*}{$\begin{array}{l}\text { Teor de } \\
\text { Lactose }\end{array}$} & \multirow[t]{2}{*}{$\begin{array}{l}\% \text { aos } 14 \\
\text { DEL }\end{array}$} & $\leq 3.8$ & 3.65 & 14.8 & 0.491 & 0.289 & 0.833 & 0.0083 \\
\hline & & $>3.8$ & 4.5 & 8.6 & Referente & - & - & - \\
\hline
\end{tabular}


Tabela 10 - Razão de chances da estimativa e intervalo de confiança do perfil máximo de verossimilhança para incidência de metrite em vacas holandesas de alta produção (AP) e de média produção (MP), no inverno (I) e no verão (V), com base na mensuração de variáveis bioquímicas no dia -21 em relação ao parto

\begin{tabular}{|c|c|c|c|c|c|c|c|c|}
\hline \multirow{2}{*}{$\frac{\text { Variável }}{\text { GGT }}$} & \multirow{3}{*}{$\begin{array}{c}\text { Unidade } \\
\text { U/L }\end{array}$} & \multirow{2}{*}{$\begin{array}{l}\text { Efeito } \\
46-90\end{array}$} & \multirow{2}{*}{$\begin{array}{c}\text { Média } \\
68.3\end{array}$} & \multirow{2}{*}{$\frac{\text { Taxa }(\%)}{19.3}$} & \multirow{2}{*}{$\frac{\text { Estimativa }}{1.009}$} & \multicolumn{2}{|c|}{$\begin{array}{l}95 \% \text { Limites de } \\
\text { confiança }\end{array}$} & \multirow{2}{*}{$\begin{array}{c}\text { Valor de } \\
\text { P } \\
0.069\end{array}$} \\
\hline & & & & & & 0.999 & 1.919 & \\
\hline \multirow{3}{*}{ CK } & & $15-45$ & 26.7 & 12.3 & Referente & - & - & - \\
\hline & \multirow{2}{*}{$\mathrm{U} / \mathrm{L}$} & $130-250$ & 228.2 & 18.2 & 1.002 & 1 & 1.003 & 0.0201 \\
\hline & & $20-120$ & 53.3 & 11.8 & Referente & - & - & - \\
\hline \multirow[t]{2}{*}{ GLI } & $\mathrm{mg} / \mathrm{dL}$ & $76-144$ & 107.6 & 19.2 & 0.993 & 0.988 & 0.999 & 0.014 \\
\hline & & $35-75$ & 52.4 & 16.9 & Referente & - & - & - \\
\hline \multirow[t]{2}{*}{ NUS } & $\mathrm{mg} / \mathrm{dL}$ & $13-25$ & 19.9 & 23.5 & 0.941 & 0.898 & 0.986 & 0.011 \\
\hline & & $2.0-12$ & 4.7 & 10 & Referente & - & - & - \\
\hline
\end{tabular}

4.5.4 Fatores preditores da ocorrência cetose e de deslocamento de abomaso

Tabela 11 - Razão de chances da estimativa e intervalo de confiança do perfil máximo de verossimilhança para incidência de cetose em vacas holandesas de alta produção (AP) e de média produção (MP), no inverno (I) e no verão $(\mathrm{V})$, com base na mensuração de variáveis bioquímicas no dia -21 em relação ao parto

\begin{tabular}{|c|c|c|c|c|c|c|c|c|}
\hline \multirow{2}{*}{$\begin{array}{c}\text { Variável } \\
\text { GGT }\end{array}$} & \multirow{2}{*}{$\begin{array}{c}\text { Unidade } \\
\text { U/L }\end{array}$} & \multirow{2}{*}{$\begin{array}{l}\text { Efeito } \\
46-90\end{array}$} & \multirow{2}{*}{$\begin{array}{c}\text { Média } \\
68.3\end{array}$} & \multirow{2}{*}{$\begin{array}{c}\text { Taxa }(\%) \\
38.3\end{array}$} & \multirow{2}{*}{$\begin{array}{c}\text { Estimativa } \\
1.022\end{array}$} & \multicolumn{2}{|c|}{$\begin{array}{c}95 \% \text { Limites de } \\
\text { confiança }\end{array}$} & \multirow{2}{*}{$\begin{array}{c}\begin{array}{c}\text { Valor de } \\
\mathrm{P}\end{array} \\
<.0001\end{array}$} \\
\hline & & & & & & 1.015 & 1.03 & \\
\hline \multirow{3}{*}{ GLI } & \multirow{3}{*}{$\mathrm{mg} / \mathrm{dL}$} & $15-45$ & 26.7 & 22.7 & Referente & - & - & - \\
\hline & & $76-144$ & 107.6 & 35.3 & 0.996 & 0.993 & 0.999 & 0.0159 \\
\hline & & $35-75$ & 52.4 & 25.6 & Referente & - & - & - \\
\hline \multirow[t]{2}{*}{ AGNE } & \multirow{2}{*}{$\mathrm{mmol} / \mathrm{L}$} & $0.9-1.6$ & 1.26 & 21.3 & 5.054 & 2.782 & 9.144 & $<.0001$ \\
\hline & & $0.1-0.8$ & 0.4 & 30.3 & Referente & - & - & - \\
\hline
\end{tabular}


Tabela 12 - Razão de chances da estimativa e intervalo de confiança do perfil máximo de verossimilhança para incidência de cetose em vacas holandesas de alta produção (AP) e de média produção (MP), no inverno (I) e no verão (V), com base em eventos durante o período de transição

\begin{tabular}{|c|c|c|c|c|c|c|c|c|}
\hline \multirow{3}{*}{$\begin{array}{l}\text { Variável } \\
\text { ECC }\end{array}$} & \multirow{3}{*}{$\begin{array}{l}\text { Unidade } \\
0.25\end{array}$} & \multirow{3}{*}{$\begin{array}{l}\text { Efeito } \\
2.5-3.0 \\
3.25-4.25\end{array}$} & \multirow{2}{*}{$\begin{array}{l}\text { Média } \\
2.65\end{array}$} & \multirow{2}{*}{$\begin{array}{l}\begin{array}{l}\text { Taxa } \\
(\%)\end{array} \\
10.1\end{array}$} & \multirow{2}{*}{$\begin{array}{l}\text { Estimativa } \\
0.755\end{array}$} & \multicolumn{2}{|c|}{$\begin{array}{l}\text { 95\% Limites de } \\
\text { confiança }\end{array}$} & \multirow{3}{*}{$\begin{array}{l}\begin{array}{l}\text { Valor } \\
\text { de P }\end{array} \\
0.0348 \\
-\end{array}$} \\
\hline & & & & & & 0.58 & 0.979 & \\
\hline & & & 3.45 & 23 & Referente & - & - & \\
\hline \multirow[t]{2}{*}{ Lactação } & \multirow[b]{2}{*}{ Número } & $3>5$ & 3.7 & 28 & 1.351 & 1.224 & 1.491 & $<.0001$ \\
\hline & & 2 & 2 & 13.6 & Referente & - & - & - \\
\hline \multirow[t]{2}{*}{$\begin{array}{l}\text { Diferença } \\
\text { Parto }\end{array}$} & \multirow{2}{*}{ dias } & 5 a 9 & 7.8 & 29.7 & 1.038 & 1.019 & 1.058 & 0.0001 \\
\hline & & 1 a 4 & 2.9 & 21.5 & Referente & - & - & - \\
\hline \multirow[t]{2}{*}{$\begin{array}{l}\text { Número } \\
\text { Bezerro }\end{array}$} & \multirow{2}{*}{ Número } & 2 & - & 32.9 & 10.47 & 6.876 & 16.132 & $<.0001$ \\
\hline & & 1 & - & 21.2 & Referente & - & - & - \\
\hline \multirow[t]{2}{*}{ Bezerro Peso } & \multirow{2}{*}{$\mathrm{kg}$} & $35-40$ & 36.4 & 17 & 0.935 & 0.915 & 0.955 & $<.0001$ \\
\hline & & $>40$ & 45.9 & 23 & Referente & - & - & - \\
\hline \multirow[t]{2}{*}{$\begin{array}{l}\text { Gordura } \\
\text { leite }\end{array}$} & \multirow{2}{*}{$\begin{array}{l}\% \text { Aos } 14 \\
\text { DEL }\end{array}$} & $\leq 3.5$ & 3.2 & 13.2 & 1.599 & 1.079 & 2.374 & 0.0196 \\
\hline & & $\geq 3.5$ & 3.7 & 27.1 & Referente & - & - & - \\
\hline \multirow{2}{*}{$\begin{array}{l}\text { Proteína do } \\
\text { leite }\end{array}$} & \multirow{2}{*}{$\begin{array}{l}\% \text { Aos } 14 \\
\text { DEL }\end{array}$} & $\geq 3.1$ & 3.55 & 27.7 & 1.428 & 1.127 & 1.811 & 0.0032 \\
\hline & & $\leq 3.1$ & 2.75 & 18.9 & Referente & - & - & - \\
\hline
\end{tabular}


Tabela 13 - Razão de chances do risco de deslocamento de abomaso em vacas holandesas de alta produção (AP) e de média produção $(\mathrm{MP})$, no inverno (I) e no verão $(\mathrm{V})$, com base em eventos durante o período de transição

\begin{tabular}{|c|c|c|c|c|c|c|c|c|}
\hline \multirow{2}{*}{$\begin{array}{c}\text { Variável } \\
\text { ECC }\end{array}$} & \multirow{2}{*}{ Unidade } & \multirow{2}{*}{$\begin{array}{c}\text { Efeito } \\
2.5-3.0\end{array}$} & \multirow{2}{*}{$\begin{array}{c}\text { Média } \\
2.65\end{array}$} & \multirow{2}{*}{$\begin{array}{c}\begin{array}{c}\text { Taxa } \\
(\%)\end{array} \\
7.6\end{array}$} & \multirow{2}{*}{$\begin{array}{c}\text { Estimativa } \\
0.55\end{array}$} & \multicolumn{2}{|c|}{$\begin{array}{l}\text { 95\% Limites de } \\
\text { confiança }\end{array}$} & \multirow{2}{*}{$\begin{array}{c}\begin{array}{c}\text { Valor de } \\
\text { P }\end{array} \\
0.0369\end{array}$} \\
\hline & & & & & & 0.312 & 0.957 & \\
\hline & 0.25 & $\begin{array}{l}3.25- \\
4.25\end{array}$ & 3.45 & 5.2 & Referente & - & - & - \\
\hline \multirow[t]{2}{*}{ ECLAU } & \multirow{2}{*}{1 to 5} & $\geq 3$ & 3.4 & 107 & 1.76 & 1.451 & 2.141 & $<.0001$ \\
\hline & & $\leq 2$ & 1.54 & 4.4 & Referente & - & - & - \\
\hline \multirow[t]{2}{*}{ Lactação } & \multirow{2}{*}{ Número } & $3>5$ & 2 & 8.9 & 0.994 & 0.989 & 0.999 & 0.0162 \\
\hline & & 2 & 3.7 & 3.7 & Referente & - & - & - \\
\hline \multirow{2}{*}{$\begin{array}{l}\text { Numero de } \\
\text { serviços na } \\
\text { lactação } \\
\text { anterior }\end{array}$} & \multirow[t]{2}{*}{ Número } & $4>6$ & 5.2 & 8.9 & 1.239 & 1.058 & 1.453 & 0.0079 \\
\hline & & 1 a 3 & 2.3 & 4.3 & Referente & - & - & - \\
\hline \multirow[t]{2}{*}{$\begin{array}{l}\text { Produção de } \\
\text { leite }\end{array}$} & $\begin{array}{c}\text { Média } \\
\text { (Kg/dia) de }\end{array}$ & $>40$ & 42.3 & 11 & 0.935 & 0.876 & 0.998 & 0.0435 \\
\hline & $\begin{array}{c}7 \text { até } 21 \\
\text { DEL }\end{array}$ & $20-40$ & 34.8 & 7 & Referente & - & - & - \\
\hline \multirow[t]{2}{*}{$\begin{array}{l}\text { Teor de } \\
\text { Lactose }\end{array}$} & \multirow{2}{*}{$\begin{array}{c}(\%) \text { aos } 14 \\
\text { DEL }\end{array}$} & $\leq 3.8$ & 3.65 & 8.5 & 0.498 & 0.281 & 0.894 & 0.0178 \\
\hline & & $>3.8$ & 4.5 & 0 & Referente & - & - & - \\
\hline
\end{tabular}

Tabela 14 - Razão de chances do risco de deslocamento de abomaso em vacas holandesas de alta produção (AP) e de média produção (MP), no inverno (I) e no verão $(\mathrm{V})$, com base na mensuração de variáveis bioquímicas no dia -21 em relação ao parto

\begin{tabular}{|c|c|c|c|c|c|c|c|c|}
\hline \multirow{2}{*}{$\frac{\text { Variável }}{\text { Período }}$} & \multirow{2}{*}{$\frac{\text { Unidade }}{-}$} & \multirow{2}{*}{$\begin{array}{l}\text { Efeito } \\
\text { Verão }\end{array}$} & \multirow{2}{*}{$\begin{array}{c}\text { Média } \\
-\end{array}$} & \multirow{2}{*}{$\frac{\text { Taxa }(\%)}{7.4}$} & \multirow{2}{*}{$\begin{array}{c}\text { Estimativa } \\
0.549\end{array}$} & \multicolumn{2}{|c|}{$\begin{array}{l}95 \% \text { Limites de } \\
\text { confiança }\end{array}$} & \multirow{2}{*}{$\begin{array}{c}\text { Valor de } \\
\text { P } \\
0.0183\end{array}$} \\
\hline & & & & & & 0.333 & 0.903 & \\
\hline & - & Inverno & - & 4.6 & Referente & - & - & - \\
\hline \multirow[t]{2}{*}{ GGT } & \multirow{2}{*}{$\mathrm{U} / \mathrm{L}$} & $46-90$ & 68.3 & 7.8 & 1.019 & 1.007 & 1.03 & 0.0008 \\
\hline & & $15-45$ & 26.7 & 5.6 & Referente & - & - & - \\
\hline \multirow[t]{2}{*}{ AST } & \multirow[t]{2}{*}{$\mathrm{U} / \mathrm{L}$} & $100-160$ & 128.1 & 7.8 & 1.011 & 1.005 & 1.016 & $<.0001$ \\
\hline & & $30-90$ & 65.6 & 5.1 & Referente & - & - & - \\
\hline \multirow[t]{2}{*}{ CK } & \multirow{2}{*}{ U/L } & $130-250$ & 228.2 & 7.5 & 0.995 & 0.992 & 0.998 & 0.0012 \\
\hline & & $20-120$ & 53.3 & 5.4 & Referente & - & - & - \\
\hline \multirow[t]{2}{*}{ BUN } & \multirow[t]{2}{*}{$\mathrm{mg} / \mathrm{dL}$} & $13-25$ & 19.9 & 11.6 & 1.031 & 1.005 & 1.057 & 0.0161 \\
\hline & & $2.0-12$ & 4.7 & 7.8 & Referente & - & - & - \\
\hline \multirow[t]{2}{*}{ AGNE } & \multirow{2}{*}{$\mathrm{mmol} / \mathrm{L}$} & $0.9-1.6$ & 1.2 & 12.6 & 2.029 & 1.974 & 2.366 & 0.0002 \\
\hline & & $0.1-0.8$ & 0.4 & 6.4 & Referente & - & - & - \\
\hline
\end{tabular}


Figura 20 - Porcentagem de eventos nos quais as variáveis metabólicas medidas no D-21 foram significantes no modelo de regressão logistica

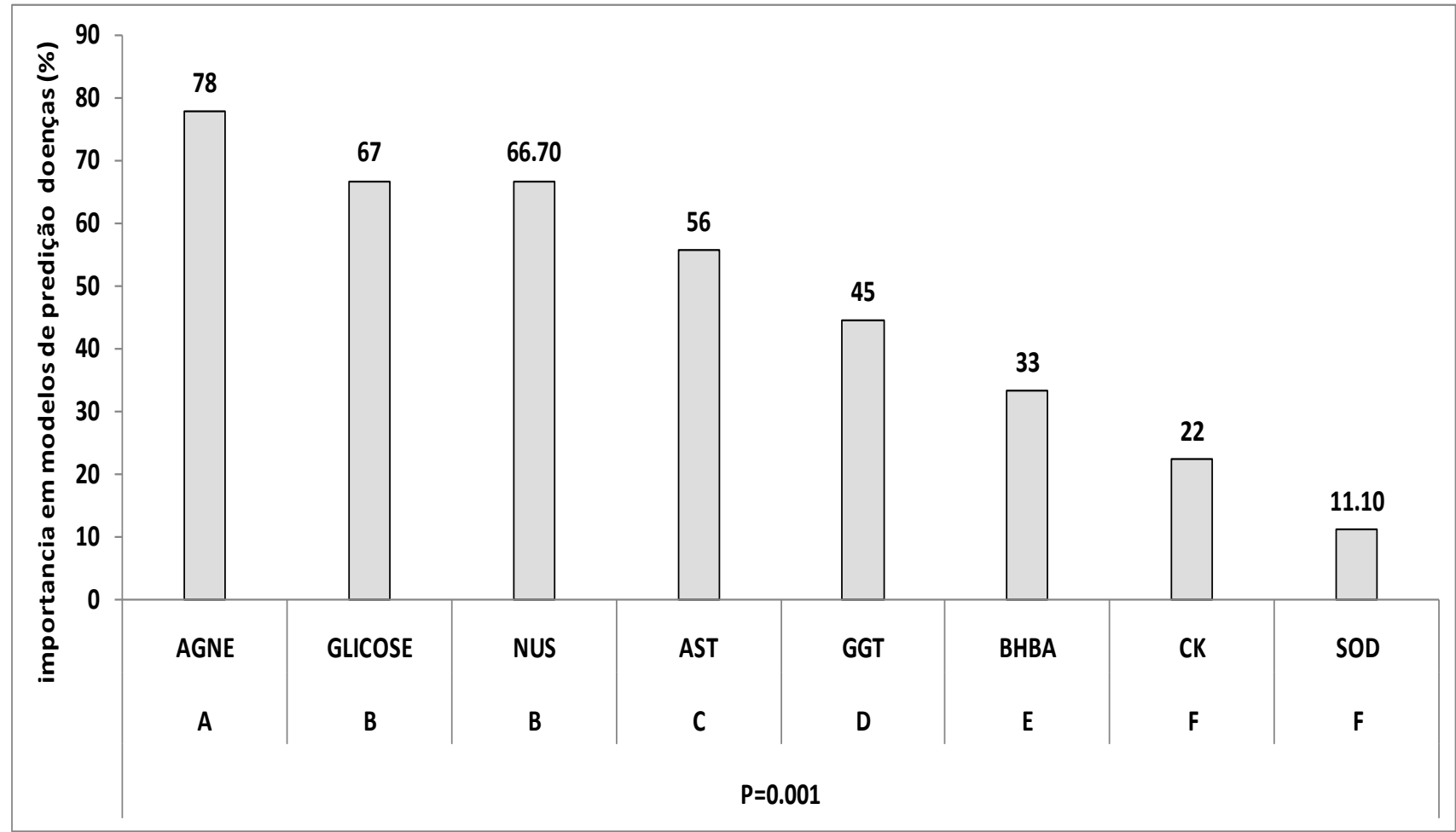

4.5.4 Conclusão Do Capitulo 2

As hipóteses deste capítulo foram parcialmente comprovadas, portanto:

1) A alta produção de leite não foi um fator de risco para a maioria das afecções puerperais estudadas nos modelos animais do presente estudo;

2) $\mathrm{O}$ verão foi fator de risco $(\mathrm{P}<0,05)$ para aumentar a incidência de doenças puerperais tanto em vacas de alta quanto média produção, como em vacas que não ficam prenhes depois de 3 serviços;

3) A ocorrência de doenças puerperais foi menor em vacas que ficaram prenhes na primeira inseminação artificial, mas a estação do ano influenciou em alguns casos

4) As variáveis glicose, AGNE, BHBA, NUS e AST, monitoradas no pré-parto, foram importantes preditoras de doenças no periodo pos-parto

5) A atividade da enzima superóxido dismutase foi importante para explicar problemas ligados à distocia. 


\section{CAPÍTULO 3: DESEMPENHO REPRODUTIVO E PRINCIPAIS VARIÁVEIS \\ PREDITORAS DA FERTILIDADE NOS TRÊS PRIMEIROS SERVIÇOS NO \\ INVERNO E NO VERÃO}

\subsection{Justificativa e Hipótese}

As diferenças metabólicas durante o período de transição, e os efeitos ambientais, como a estação do ano, tem sido relatado como fatores de risco na fertilidade de vacas leiteiras de alta produção. Embora estratégias de manejo reprodutivo, com protocolos hormonais, aliadas a melhoria da condição de conforto para vacas estabuladas tenham sido utilizadas nas ultimas décadas para melhorar a taxa de prenhez em rebanhos leiteiros, a eficiência reprodutiva ainda é afetada por inúmeros eventos metabólicos, que mesmo não afetando a incidência de doenças em alguns casos, tem gerado infertilidade e subfertilidade nas vacas leiteiras.

Esses problemas de fertilidade acarretam em perdas produtivas por lactação e por tempo de vida útil da vaca e afeta a rentabilidade da pecuária leiteira.

Os padrões de variações de alguns metabólitos podem auxiliar na compreensão destes eventos, sendo que, encontrar marcadores durante o período de transição que possam predizer a fertilidade no primeiro serviço é de suma importância na compreensão de fatores fisiológicos, para que abordagens mecanisticas bem como estratégias de manejo possam ser desenvolvidas após a interpretação de parâmetros gerados em estudos epidemilógicos. Principalmente, entendo as diferenças nos teores e nos padrões de variação como preditores da fertilidade em vacas de diferente produtividade leiteira, bem como o efeito das estações do ano.

As Hipoteses gerais do presente capítulo são:

1) A alta produção de leite compromete a fertilidade de vacas leiteiras nos três primeiros serviços, no inverno e no verão;

2) O verão é um fator de risco para diminuir a fertilidade nos três primeiros serviços em vacas leiteiras;

3) As principais variáveis preditoras de doenças (AGNE, glicose, BHBA. NUS e AST), também são eficientes para predição da prenhez no primeiro serviço, no inverno e no verão. 


\subsection{Objetivos}

O presente capítulo tem como objetivo verificar as diferenças metabólicas que influenciam a taxa de prenhez nos tres primeiros serviços em vacas leiteiras.

\subsection{Objetivos Específicos}

Como objetivos específicos, este capítulo visa:

1) Compreender as relações entre o metabolismo protéico, energético e hepático sobre a taxa de prenhez de vacas leiteiras no invernmo e no verão.

2) Indicar quais variáveis são importantes como preditoras da taxa de prenhez no primeiro serviço, independente da produtividade ou da estação do ano.

3) Apontar quais são as principais diferenças metabólicas durante os primeiros 150 dias de lactação que ocorrem entre vacas de média e alta produção leiteira no inverno e no verão.

4) Verificar quais variáveis metabólicas podem ser mensuradas no final do período de transição ou no dia da primeira inseminação que serão preditoras da fertilidade em vacas leiteiras no inverno e no verão.

\subsection{Materiais e Métodos}

O manejo dos animais no experimento, foi dividido em duas fases, assim como descrito no tópico 3.4 do capitulo 1. As variáveis mensuradas, os pontos de avaliação, bem como a descrição do protocolo de IATF estão descritas nas figuras 21 e 22.

Figura 21 - Caracterização do protocolo de IATF e dos manejos reprodutivos subseqüentes (ressincronizações) 
Capítulo 3 - Desempenho reprodutivo e principais variáveis preditoras da fertilidade

\section{Protocolo de IATF}

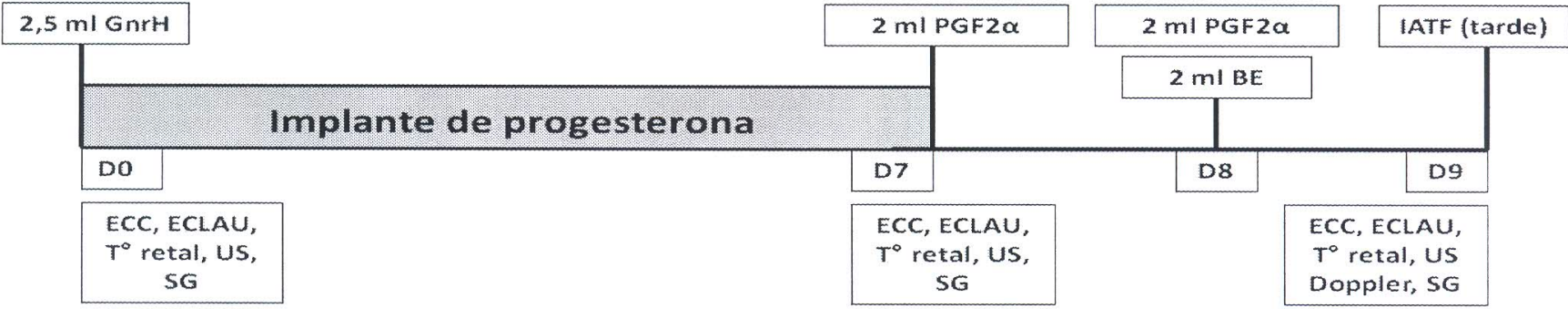

\section{Protocolo de ressincronização}

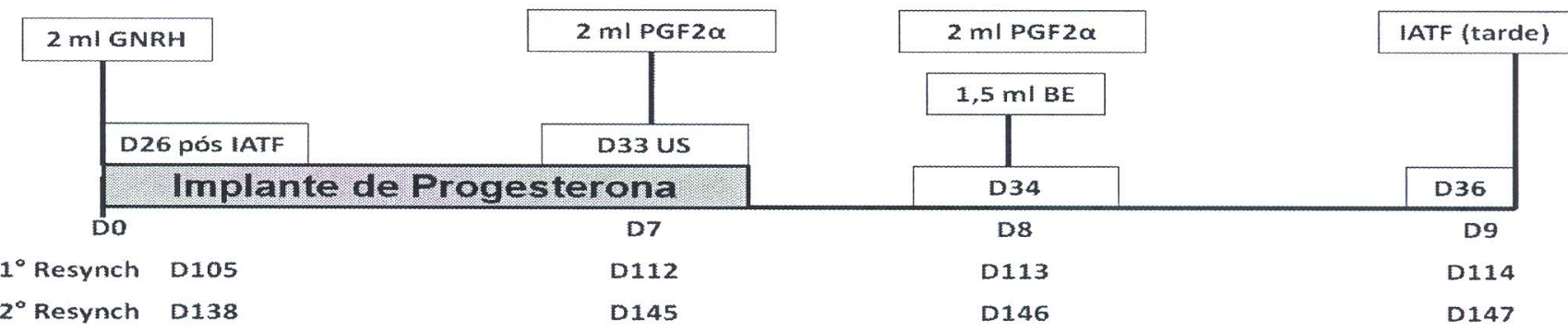

Fonte: (MATURANA FILHO, 2013).

Figura 22 - Caracterização do protocolo de pré sincronização e de IATF e as variáveis mensuradas

\section{Pré Sincronização e sincronização da $1^{\circ}$ IATF}

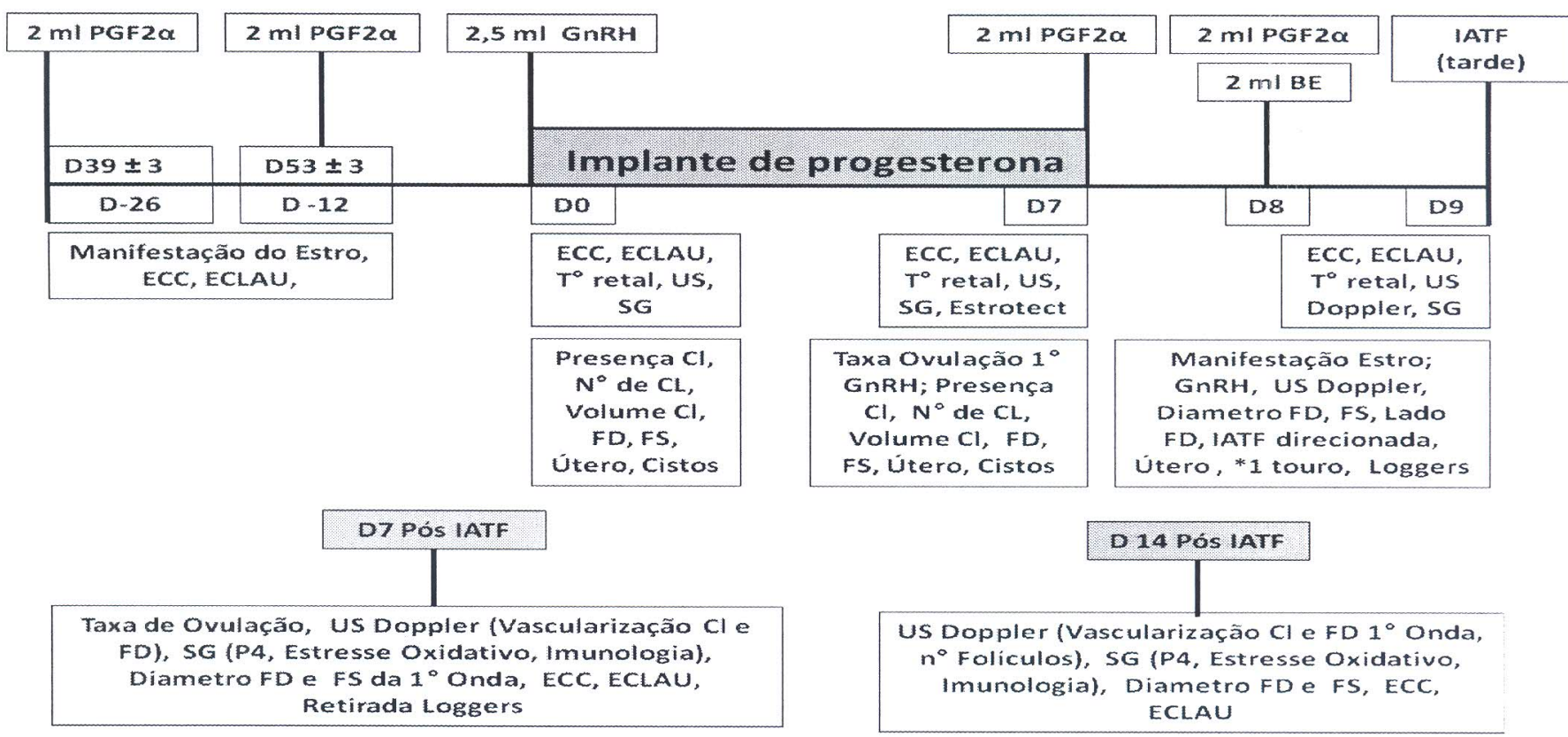

Fonte: (MATURANA FILHO, 2013). 
5.4.1 Analises estatísticas

As informações individuais das vacas foramm dispostas em uma única planilha, para a realização das análises estatísticas.

As análises estatísticas foram realizadas utilizando o programa SAS versão 9.3 (SAS / STAT ®, SAS Inst. Inc., Cary, NC, 2012). Os modelos estatísticos utilizados para avaliar esses dados, seguem os critérios adotados para avaliar as variáveis metabólicas, conforme descrito no item 3.4.3 do capitulo 1 .

As variáveis: escore de condição corporal (ECC), escore de claudicação (ECLAU), foram avaliados utilizando a matriz AIC para modelos mistos de medidas do PROC MIXED (SAS, 2012). Ao avaliar essas variáveis foram considerados os efeitos grupo de produção ou grupo de prenhez, período do ano, dias (pontos de coleta), e as interações duplas e triplas entre estes fatores.

Para todas as variáveis foram realizadas análises de homogeneidade das variâncias e normalidade dos resíduos (Shapiro-Wilk). Todos os out-liers foram excluídos ou transformados, quando necessário, antes dos dados serem submetidos a analise de regressão logística (Proc Logistic, SAS versão 9.3, 2012).

$\mathrm{Na}$ analise de regressão logística, foram incluídos todos os fatores metabólicos, produtivos e reprodutivos, aliado aos modelos animais para predição de valores binários, ligados a taxa de prenhez nos três primeiros serviços. Os dados foram analisados por regressão logística multivariada, usando o modelo "backward stepwise regression" e as variáveis explanatórias foram sequencialmente removidas do modelo estatístico, seguindo o critério de wald, onde: $\mathrm{P}>0,10$, excluí-se do modelo. Valores de $\mathrm{P}<0,05$ são considerados significantes.

Os dados são expressos como média como uma medida da tendência central, e o erro padrão da média como medida de dispersão. O nível de significância utilizado para rejeitar a hipótese H0 (hipótese nula) para todos os dados obtidos foi $\mathrm{P}<0,05$ e tendências estatísticas como $\mathrm{P}<0,10$ foi considerado. 


\subsection{RESULTADOS}

5.5.1 Taxa de prenhez e taxa de ciclicidade

Não houve diferenças $(\mathrm{P}>0,05)$ na taxa de prenhez média e na taxa de prenhez acumulada aos 150 dias entre os grupos e entre os períodos experimentais nos três primeiros serviços. Isso pode ser explicado por não ter ocorrido diferenças significativas na ocorrência de doenças, e na taxa de ciclicidade entre os grupos experimentais, embora alguns estudos tenham demonstrado que vacas de elevada produção leiteira têm apresentado um aumento gradativo em problemas reprodutivos ao longo dos anos (LUCY et al., 2001; WASHBURN et al., 2002). Outros autores tem relacionados a baixa fertilidade de vacas leiteiras nos primeiros serviços com o período de balanço energético negativo durante o início da lactação e redução dos pulsos de LH necessários para estimular os estágios finais do crescimento folicular e produção de E2 (BEAM; BUTLER, 1997; LAMMING; DARWASH, 1998; STAPLES et al., 2000; ROCHE et al., 2000; BUTLER, 2001; BUTLER 2003).

Foi hipotetizado no presente estudo que a fertilidade seria influenciada pela alta produção leiteira. Assim como mencionado anteriormente, a taxa de ciclicidade tem sido apontada como um fator que compromete a taxa de prenhez no primeiro serviço. Entretanto, isso não ocorreu no presente estudo, o que corrobora com Lopez et al. (2005), que não verificaram correlação entre o nível de produção de leite e a porcentagem de vacas anovulatórias entre os 50 e 71 dias em lactação (LOPEZ et al., 2005).

Alguns pesquisadores sugerem que um retorno mais cedo a ciclicidade seja benéfico ao desempenho reprodutivo (SENATORE et al., 1996; DARWASH et al., 1997). A justificativa seria de que o aumento no número de ciclos estrais antes da inseminação artificial (IA) estaria associado a uma atividade folicular e uterina mais regular, o que levaria a uma maior taxa de concepção na primeira IA (THATCHER; WILCOX, 1973). Entretanto, no presente estudo não foi verificado diferenças na taxa de prenhez em vacas que estavam ou não cíclicas nas avaliações realizadas. Provavelmente isso se deve ao manejo reprodutivo utilizado.

Em, outros estudos relataram foi verificado uma queda na eficiência reprodutiva em vacas de alta produção, mesmo aquelas com atividade luteal mais precoce no período pósparto (BALL; MCEWAN, 1998; SMITH; WALLACE, 1998), mas no presente estudo, isso também não se confirmou. 
No protocolo de sincronização utilizado no presente estudo, baseado no Ovsynch (PURSLEY et al., 1995) adicionado de pregesterona, após uma prévia pre sincronização, com duas prostaglandinas, foi um programa eficiente para garantir uma taxa de prenhez das vacas de verão semelhante as das vacas de inverno, o que corrobora com os achados de Stevenson et al. (2006).

Figura 23 - Taxa de prenhez acumulada aos 150 DEL de acordo com a estação do ano

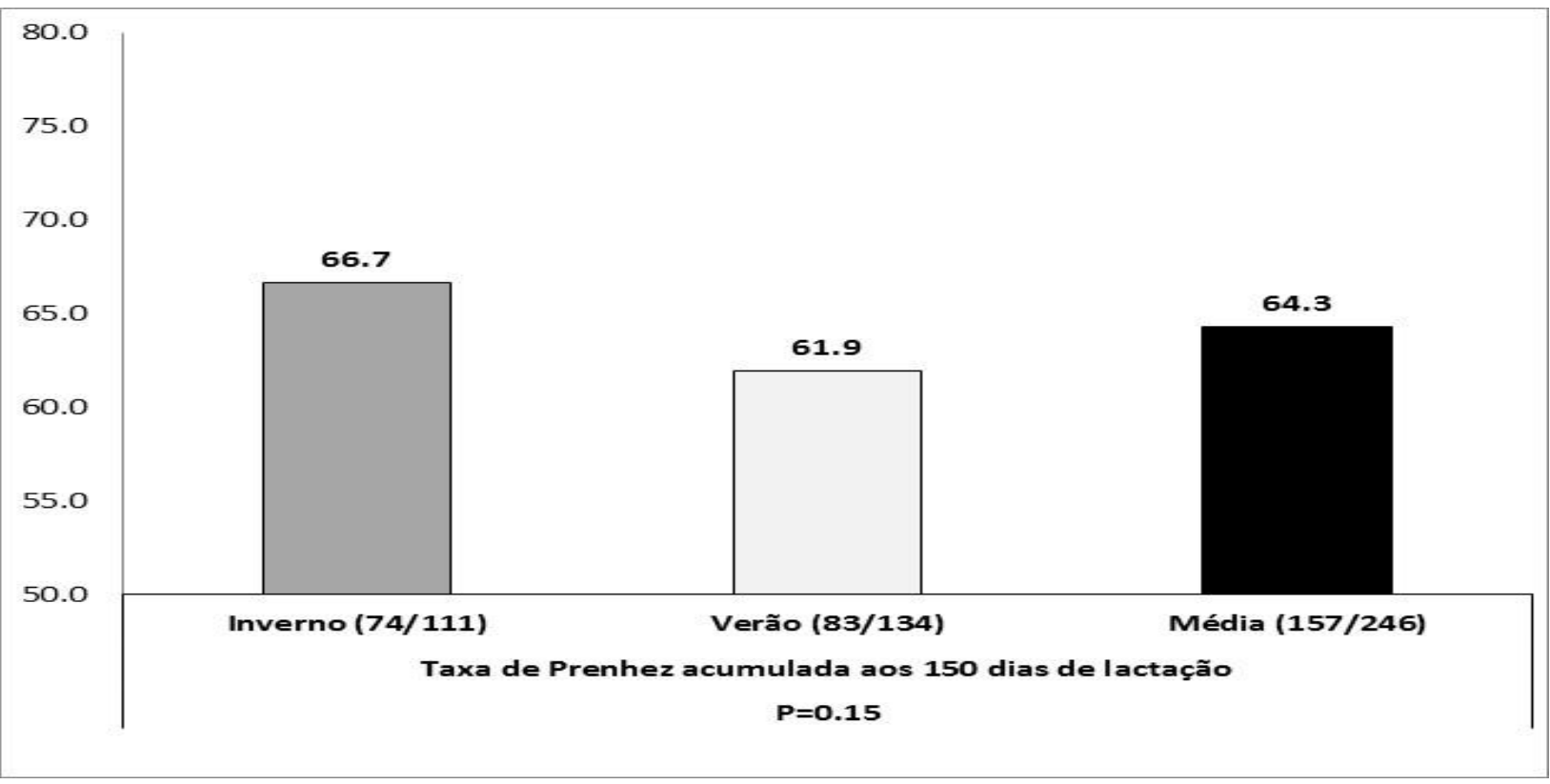

Figura 24 - Taxa de prenhez média durante os três serviços de acordo com a estação do ano

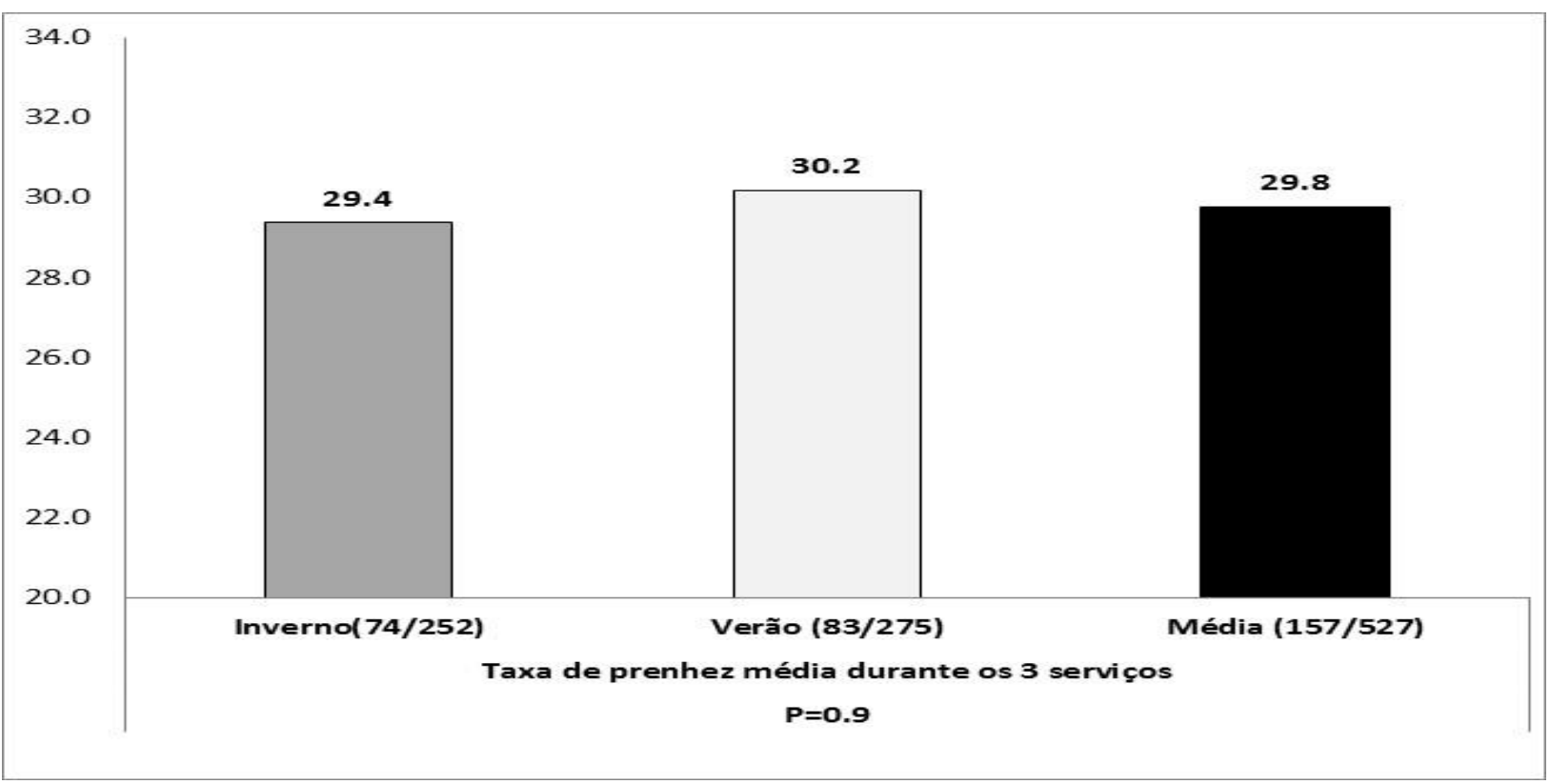


Figura 25 - Taxa de prenhez acumulada aos 150 DEL de acordo com a produção de leite

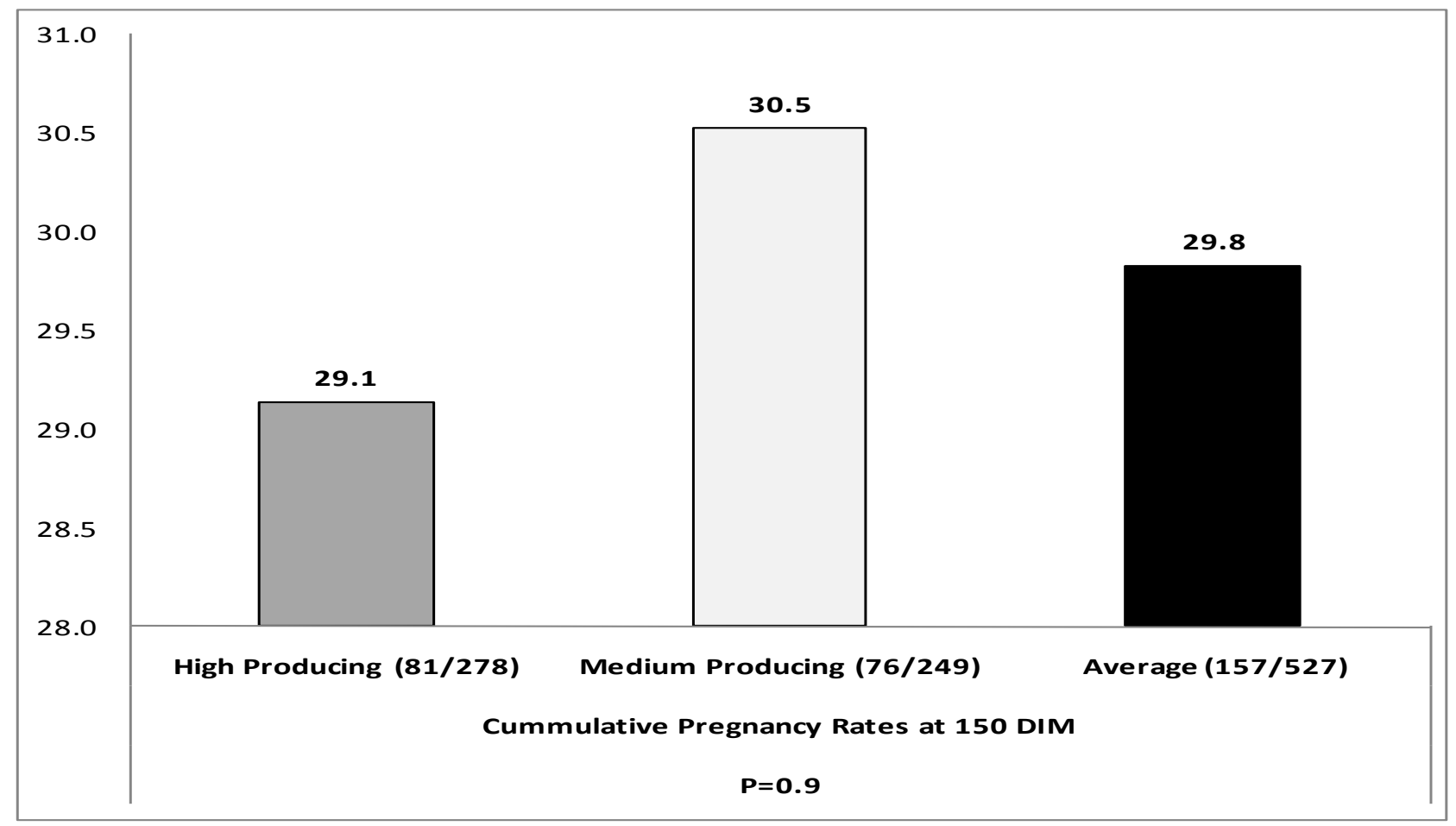

Figura 26 - Taxa de prenhez média durante os 3 primeiros serviços de acordo com a produção de leite

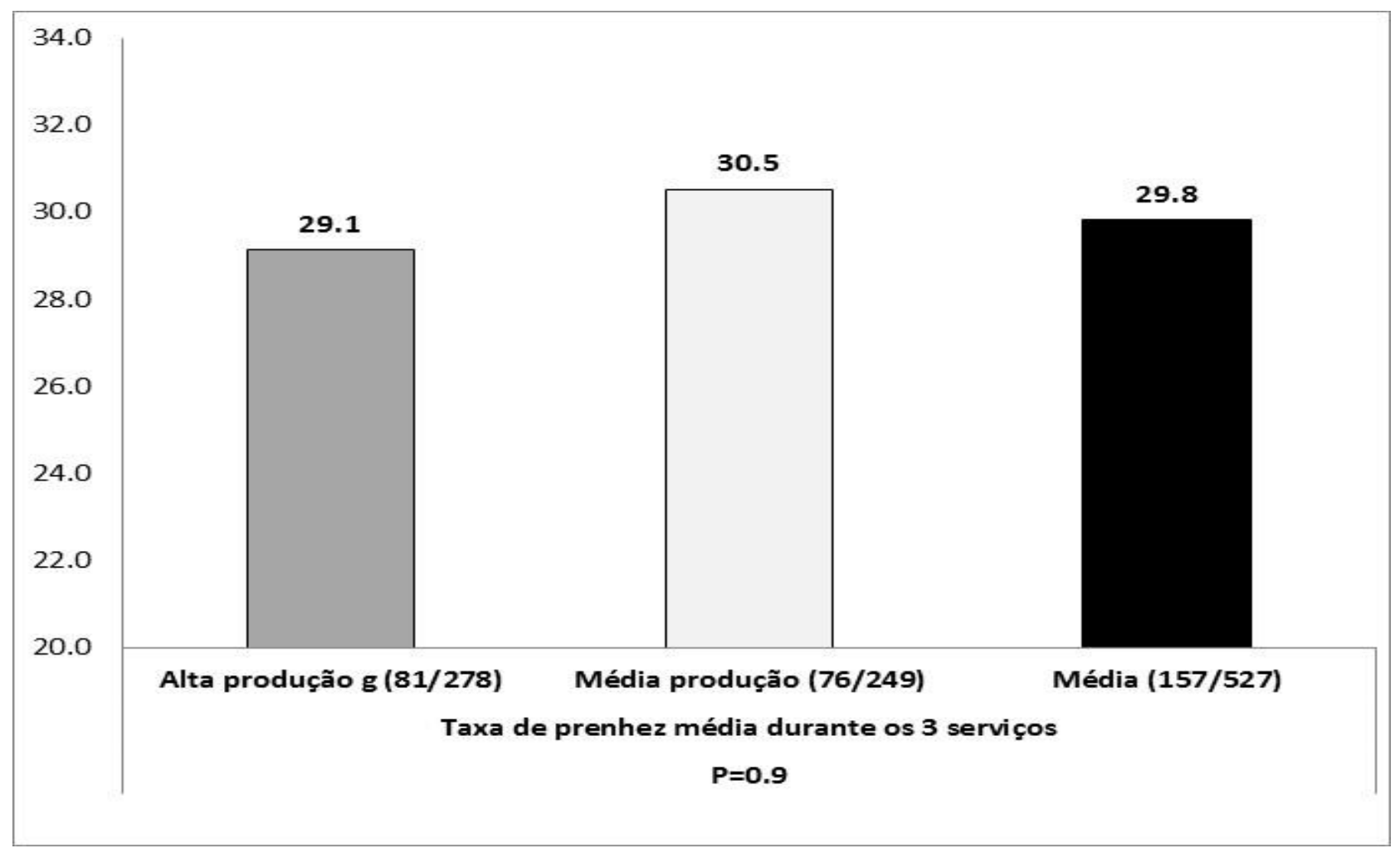


Tabela 15 - Taxa de ciclicidade de vacas holandesas de alta produção (AP) e de média produção (MP), no inverno (I) e no verão (V)

\begin{tabular}{|c|c|c|c|c|c|}
\hline \multirow[b]{2}{*}{ Variáveis } & \multicolumn{4}{|c|}{ Grupos experimentais } & \multirow[b]{2}{*}{ Valor de $\mathbf{P}$} \\
\hline & $\begin{array}{c}\text { API }^{1} \\
(n=60)\end{array}$ & $\begin{array}{c}\text { MPI }^{2} \\
(n=51)\end{array}$ & $\begin{array}{c}\text { APV }^{1} \\
(n=70)\end{array}$ & $\begin{array}{c}M^{M P V}{ }^{2} \\
(n=64)\end{array}$ & \\
\hline & & Ciclicidade & & & \\
\hline Taxa de ciclicidade aos $39 \pm 3$ DEL, $\%$ & 60 & 64.7 & 62.8 & 62.5 & 0.22 \\
\hline Taxa de ciclicidade aos $53 \pm 3$ DEL, $\%$ & 71.7 & 74.5 & 68.6 & 71.8 & 0.19 \\
\hline
\end{tabular}

5.5.2 Fatores metabólicos ligados a taxa de prenhez na primeira inseminação

No presente estudo, as variáveis: glicose, AGNE, PLC, Lactose e CCS, sendo mensuradas no D21 ou no dia da IATF foram importantes no modelo de predição da prenhez no primeiro $(\mathrm{P}<0,05)$, conforme tabelas 17,18 e figuras $27,28,29$ e 30 .

No modelo utilizado para predição da prenhez foi observado que os teores de glicose são diferente entre as vacas que ficam prenhes na primeira inseminação. Gonzalez (1997) acredita que os resultados obtidos nos estudos que relacionam a concentração de glicose e a fertilidade são inconsistentes.

No presente estudo os baixos teores de glicose foram condizentes com queda na taxa de prenhez. Seifi, Mirschokraie e Farzaneh (2003) encontraram em suas pesquisas correlação negativa entre altos teores de glicose e taxa de prenhez. Assim como no presente estudo, Nejad e Charaghi (2003) e Jorristma et al. (2004) observaram uma relação positiva entre a altos teores de glicose (por volta de $90 \mathrm{mg} / \mathrm{dL}$ ) com a atividade ovariana e com a fertilidade no primeiro serviço.

Concentrações elevadas AGNE foram encontradas em ambos os grupos de produção e em ambos os períodos experimentais. No caso das vacas que ficaram vazias ou doentes, também foi característico, baixos teores de glicose e altos teores de BHBA e AST no inicio do pós-parto. Essas altas concentrações de AGNE foram provavelmente, características de um metabolismo altamente exigente, no caso das vacas de alta produção, ou, caracteristicas em situações de grande instabilidade nas reações do organismo, como no caso das vacas doente ou nas vazias depois de três serviços. No estudo de VanHoeck et al. (2013), também foi hipotetizado que animais com altos teores de AGNE, apresentam mecanismos orgânicos 
comprometidos, semelhante ao de pacientes com diabetes tipo II, o que corrobora com outros estudos com vacas leiteiras (REAVEN et al., 1988; MOORADIAN et al., 2008).

No presente estudo, altas concentrações de NEFA, levaram a diminuição da fertilidade $(\mathrm{P}<0,05)$. Isso pode estar relacionado a mudanças no ambiente folicular e na qualidade do oócito. Embora os oócitos das vacas do presente trabalho não tenham sido estudado, outros estudos suportam essa hipótese sobre os efeitos das altas concentrações de AGNE sobre o desenvolvimento e capacidade do oócito capacidade, tanto in vitro como in vivo (JORRITSMA et al., 2004; LEROY et al., 2005; AARDEMA et al., 2011; VANHOECK et al., 2013).

Foi observado um comprometimento dos teores e nos padrões de variação da glicose e AGNE em vacas que não ficaram prenhes após três serviços no presente estudo $(\mathrm{P}<0,05)$. Essas mudanças provavelmente afetaram o metabolismo oxidativo, pois, nessas vacas os teores médios de SOD foram abaixo dos limites inferiores de $3037 \mathrm{U} / \mathrm{g} \mathrm{Hb}$ encontrado nas vacas que desenvolveram alguma infecção uterina. Embora essa enzima não tenha sido eficiente preditora da fertilidade nas vacas de leite do presente estudo, a baixa atividade dessa enzima foi uma característica nos animais que não ficaram prenhes, o que opde estar ligado a problemas no oócito ou no desenvolvimento do embrião. Esta hipótese corrobora com Van Hoeck et al. (2011) que verificou que embriões originados a partir de oócitos expostos a concentrações elevadas de AGNE apresentam um metabolismo oxidativo alterado, comprometimento do metabolismo da glicose e alterações da expressão gênica nos primeiros dias de desenvolvimento do embrião.

Tabela 16 - Razão de chances da estimativa e intervalo de confiança do perfil máximo de verossimilhança para o risco de prenhez (aos 60 dias) na primeira IATF $(75 \pm 3)$ em vacas holandesas de alta produção (AP) e de média produção (MP), no inverno (I) e no verão (V), com base na mensuração de variáveis bioquímicas, hematológicas e de produção no dia 21 pós parto

\begin{tabular}{|c|c|c|c|c|c|c|c|c|}
\hline Variável & Unidade & Efeito & Média & $\begin{array}{l}\text { Taxa de } \\
\text { Prenhez }\end{array}$ & Estimativa & \multicolumn{2}{|c|}{$\begin{array}{l}95 \% \text { Limites de } \\
\text { confiança }\end{array}$} & $\begin{array}{l}\text { Valor } \\
\text { de P }\end{array}$ \\
\hline \multirow[t]{2}{*}{ Proteína total } & \multirow{2}{*}{$\mathrm{mg} / \mathrm{dl}$} & $80-120$ & 92.2 & 37.9 & 1.972 & 1.895 & 2.098 & 0.0015 \\
\hline & & $35-79$ & 62.2 & 24.6 & Referente & - & - & - \\
\hline \multirow[t]{2}{*}{ Glicose } & \multirow[t]{2}{*}{$\mathrm{mg} / \mathrm{dL}$} & $76-144$ & 107.6 & 30.9 & 3.799 & 3.196 & 3.997 & 0.0051 \\
\hline & & $35-75$ & 52.4 & 23.4 & Referente & - & - & - \\
\hline \multirow[t]{2}{*}{ HDL } & \multirow{2}{*}{$\mathrm{mg} / \mathrm{dl}$} & $\begin{array}{l}16.2- \\
34.5\end{array}$ & 25.4 & 26.6 & 0.94 & 0.895 & 0.986 & 0.0116 \\
\hline & & $35-65$ & 45.2 & 20 & Referente & - & - & - \\
\hline \multirow[t]{2}{*}{ AGNE } & \multirow{2}{*}{$\mathrm{mmol} / \mathrm{L}$} & $0.9-1.6$ & 1.26 & 29.5 & 0.931 & 0.879 & 0.987 & 0.014 \\
\hline & & $0.1-0.8$ & 0.4 & 24 & Referente & - & - & - \\
\hline
\end{tabular}


Tabela 17- Razão de chances da estimativa e intervalo de confiança do perfil máximo de verossimilhança para o risco de prenhez (aos 60 dias) na primeira IATF $(75 \pm 3)$ em vacas holandesas de alta produção (AP) e de média produção (MP), no inverno (I) e no verão (V), com base na mensuração de variáveis bioquímicas e de produção no dia da IATF

\begin{tabular}{ccccccccc}
\hline \multirow{2}{*}{ Variável } & Unidade & Efeito & Média & $\begin{array}{c}\text { Taxa de } \\
\text { Prenhez }\end{array}$ & Estimativa & $\begin{array}{c}\text { 95\% Limites de } \\
\text { confiança }\end{array}$ & Valor de P \\
\hline Globulinas & \multirow{2}{*}{$\mathrm{mg} / \mathrm{dL}$} & $15-40$ & 31.2 & 34.6 & 0.962 & 0.892 & 0.997 & 0.0139 \\
& & $40-90$ & 49.7 & 28.6 & Referente & - & - & - \\
GGT & & $46-90$ & 68.3 & 29.3 & 0.986 & 0.972 & 1.021 & 0.0714 \\
& $\mathrm{U} / \mathrm{L}$ & $15-45$ & 26.7 & 25.1 & Referente & - & - & - \\
CK & & $130-250$ & 228.2 & 31.9 & 0.153 & 0.053 & 0.357 & 0.0495 \\
& \multirow{2}{*}{ U/L } & $20-120$ & 53.3 & 28.4 & Referente & - & - & - \\
\multirow{2}{*}{ Alicose } & \multirow{2}{*}{$\mathrm{mg} / \mathrm{dL}$} & $76-144$ & 107.6 & 30.5 & 0.99 & 0.971 & 1.001 & 0.0472 \\
& & $35-75$ & 52.4 & 25.2 & Referente & - & - & - \\
& \multirow{2}{*}{$\mathrm{mmol} / \mathrm{L}$} & $0.1-0.8$ & 0.4 & 33.1 & 0.567 & 0.365 & 0.862 & 0.0243 \\
& & $0.9-1.6$ & 1.26 & 27.2 & Referente & - & - & - \\
\hline
\end{tabular}

Figura 27 - Probabilidade de prenhez no primeiro serviço de acordo com as concentrações plasmáticas de glicose $(\mathrm{mg} / \mathrm{dL})$ no D21. [Probabilidade de prenhez $=\exp (-0.00484+$ $0.00178 *$ concentração de glicose / $1+\exp (-0.00484+0.00178 *$ concentração de glicose $)$; $\mathrm{P}=0.005)]$

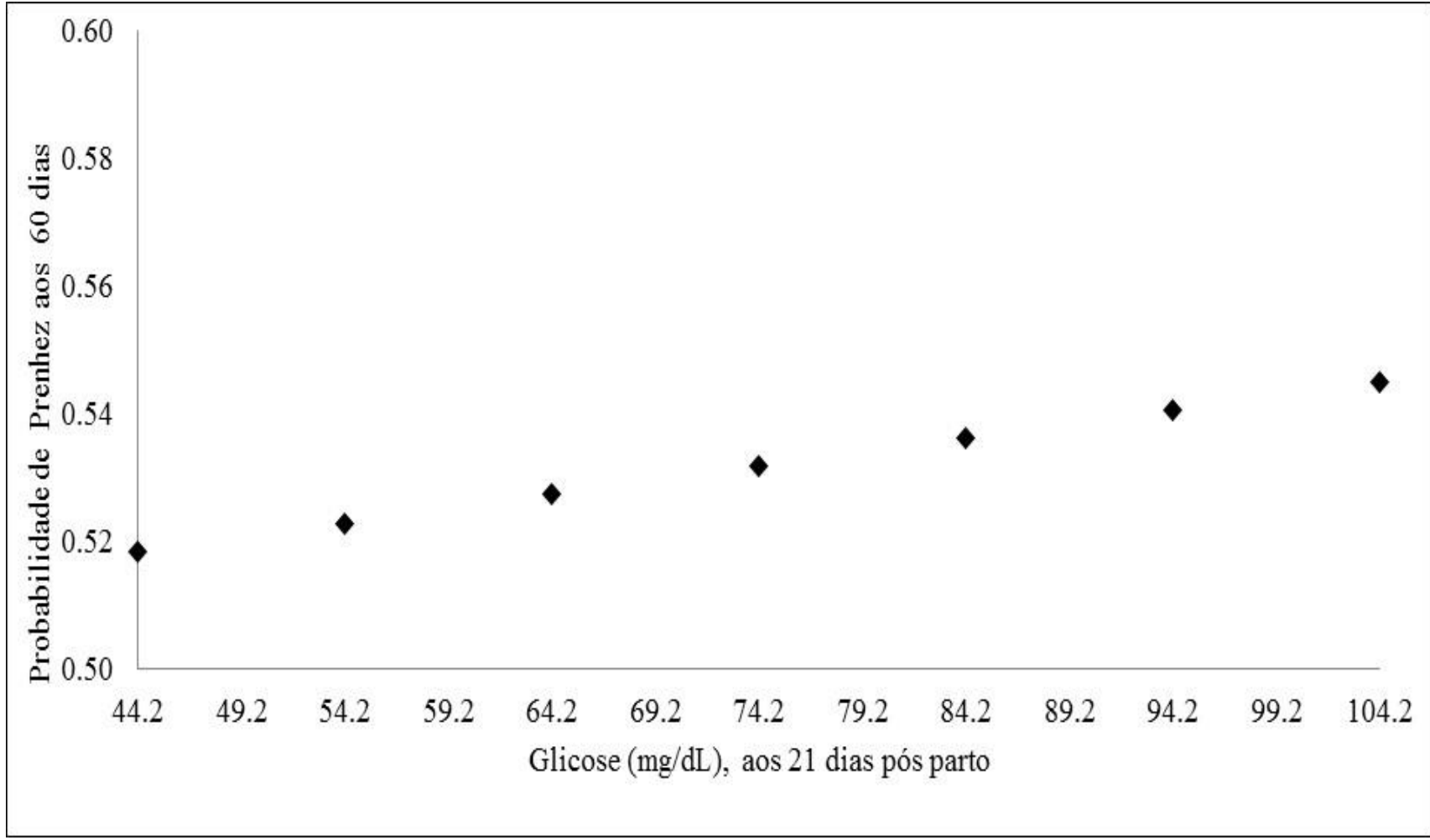


Figura 28- Probabilidade de prenhez no primeiro serviço de acordo com os teores de AGNE (mmol/L) no D21. [Probabilidade de prenhez $=\exp (0.30191-1.2281 *$ AGNE/ $1+\exp (0.30191-$ 1.2281*AGNE); $\mathrm{P}=0.014)$ ]

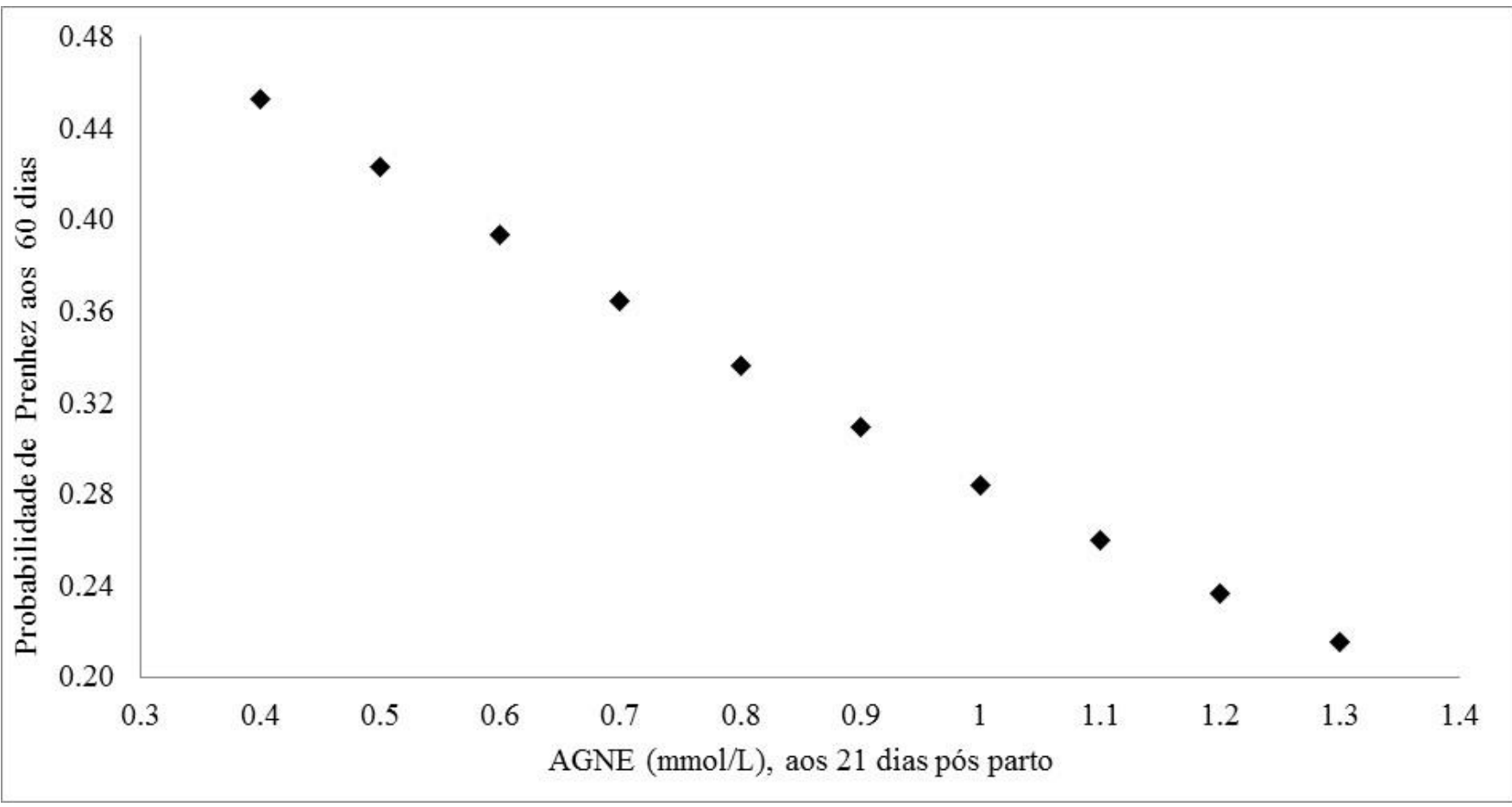

Figura 29 - Probabilidade de prenhez no primeiro serviço de acordo com as concentrações plasmáticas de glicose $(\mathrm{mg} / \mathrm{dL})$ no momento da IATF. [Probabilidade de prenhez $=\exp (-0.0209+$ $0.00783 *$ concentração de glicose $/ 1+\exp (-0.0209+0.00783 *$ concentração de glicose $)$; $\mathrm{P}=0.0047)]$

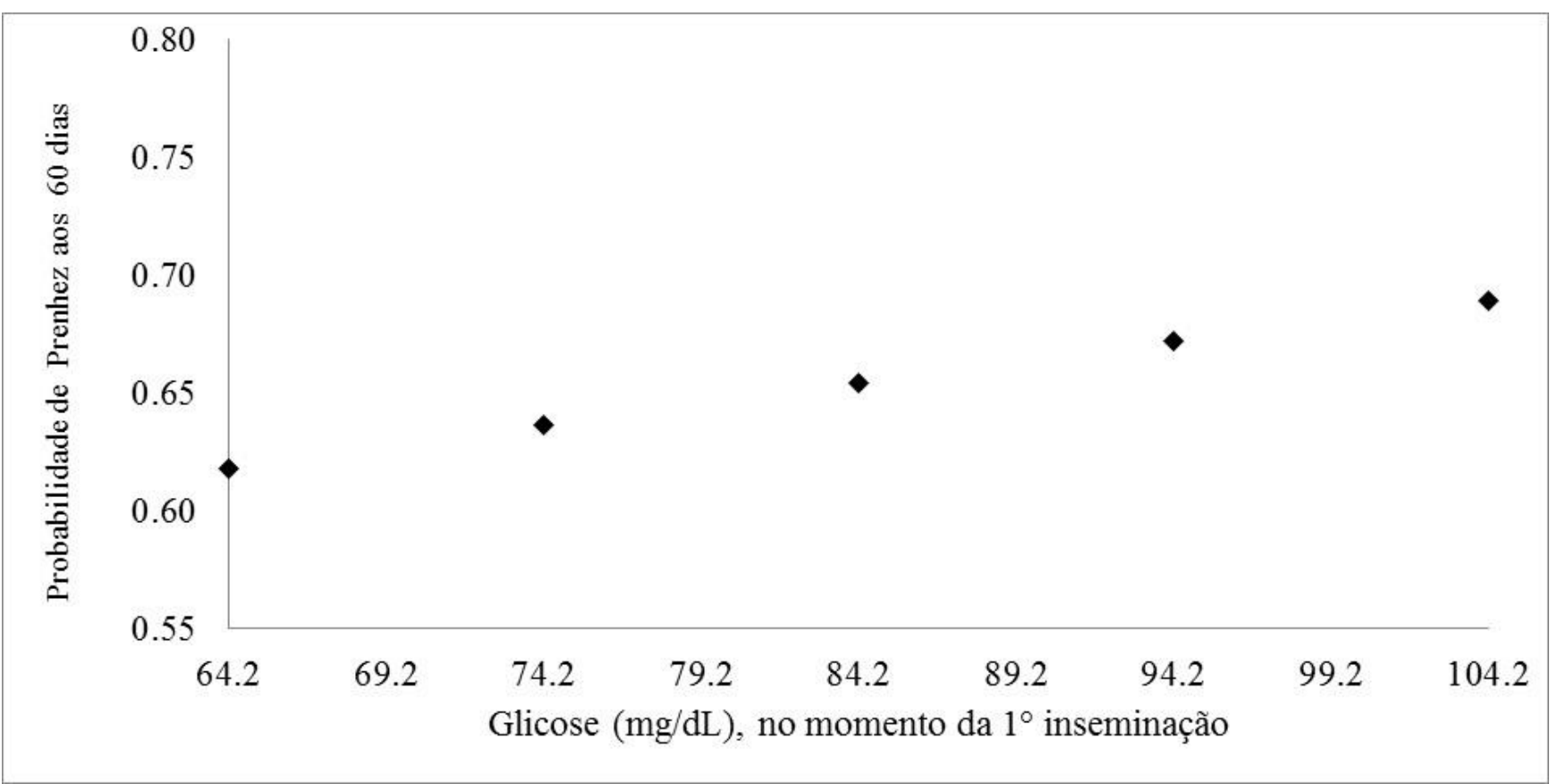


Figura 30 - Probabilidade de prenhez no primeiro serviço de acordo com os teores de AGNE (mmol/L) no momento da IATF. [Probabilidade de prenhez $=\exp (0.8812-0.2576 *$ AGNE/ $1+\exp$ (0.8812-0.2576*AGNE); $\mathrm{P}=0.024)]$

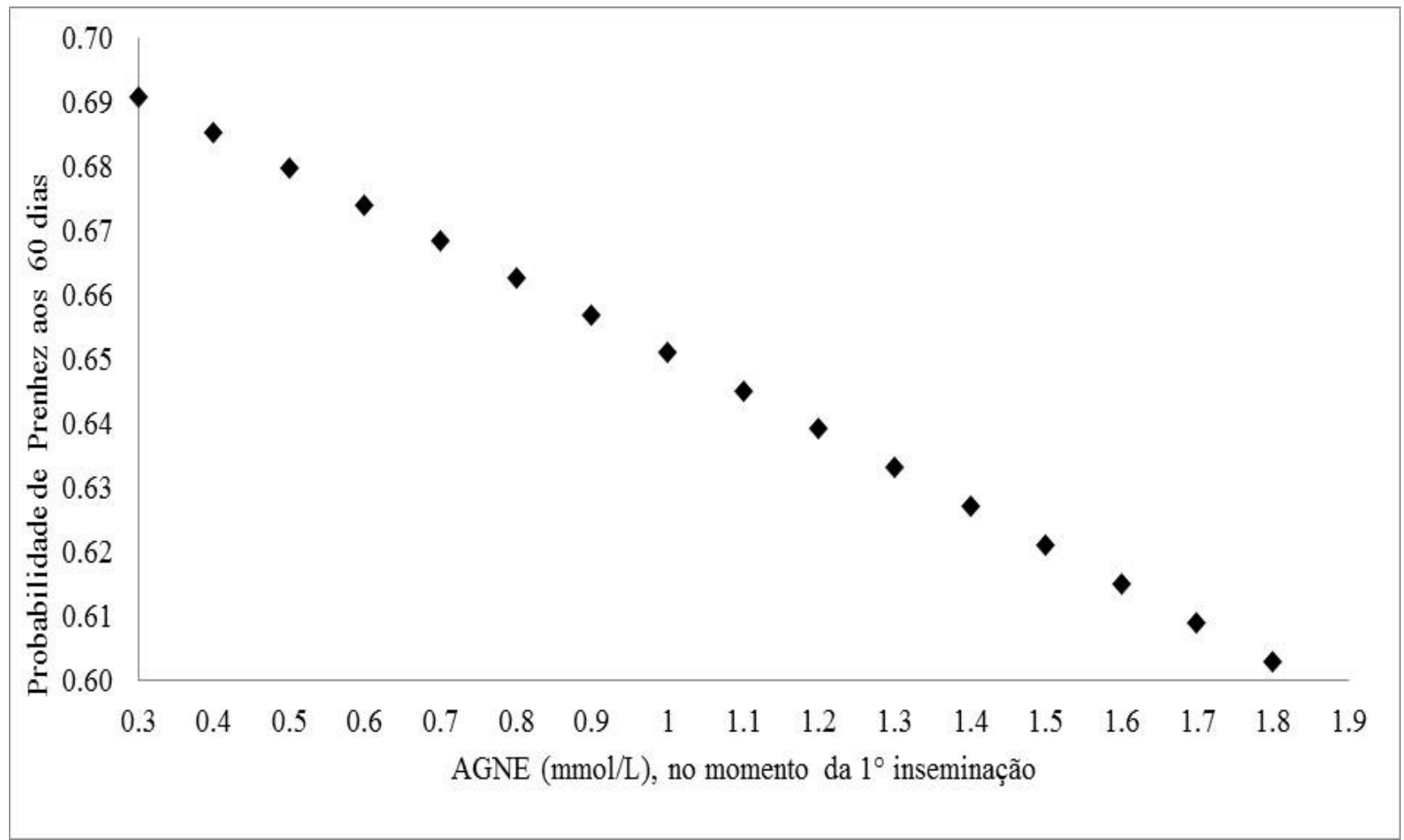

5.5.3 Conclusão capítulo 3

As diferenças metabólicas durante o período de transição, principalmente relacionado a variáveis ligadas ao perfil energético, afetam a fertilidade de vacas leiteiras no inverno e no verão. Baseado nas hipóteses do presente capítulo, foi possível concluir que:

1) A produção leiteira não é um fator de risco para as vacas permanecerem vazias após os três primeiros serviços, tanto no inverno como no verão, mas sim a condição e a recuperação de teores normais de variáveis metabólicas, principalmente ligadas ao metabolismo energético;

2) O verão é um fator de risco para diminuir a fertilidade nos três primeiros serviços em vacas leiteiras;

3) As variáveis AGNE e glicose são as preditoras mais eficientes da prenhez no primeiro serviço, independentemente da estação do ano e do potencial produtivo. 


\section{CONCLUSÕES GERAIS}

Com base nos resultados obtidos dentro das condições deste experimento conclui-se que:

1) O monitoramento metabólico no pré parto é uma ferramenta importante a ser difundida nas fazendas leiteiras no Brasil para direcionar quais são os animais com risco para desenvolver doenças no início do período de lactação;

2) O monitoramento metabólico no início do período de lactação é importante para direcionar na identificação de animais com problemas metabólicos inaparentes ao exame clinico, pois, existe diferenças no perfil metabólico até mesmo entre vacas de mesma produção leiteira e na mesma estação do ano que podem afetar a produção de leite e a fertilidade nos três primeiros serviços. De modo que esses animais possam ser tratados diferencialmente durante esse período de maior risco;

3) Estratégias de manejo, bem como os valores normais de cada fazenda, ou região produtora, possam ser ajustadas para maximizar a rentabilidade em diferentes sistemas de produção;

4) As variáveis glicose, AGNE, BHBA, NUS e AST, monitoradas no pré-parto e no início do período pós parto são importantes preditoras de doenças e também da fertilidade

5) A produção leiteira não é um fator de risco para as vacas permanecerem vazias após os três primeiros serviços, tanto no inverno como no verão, mas sim a condição e a recuperação de teores normais de variáveis metabólicas, principalmente ligadas ao metabolismo energético. 


\section{REFERÊNCIAS}

AARDEMA, H.; VOS PLAM, L. F.; ROELEN, B. A. J.; KNIJN, H. M.; VAANDRAGER, A. B.; HELMS, J. B.; GADELLA, B. M. Oleic acid prevents detrimental effects of saturated fatty acids on bovine oocyte developmental competence. Biology of Reproduction, v. 85, p. 62-69, 2011. (doi:10.1095/biolreprod.110. 088815).

AGARWAL. A.; APONTE-MELLADO, A.; PREMKUMAR, B. J.; SHAMAN, A.; GUPTA, S. 2012 The effects of oxidative stress on female reproduction: a review. Reproductive Biology and Endocrinology, v. 10, p. 49, 2012. (doi:10.1186/1477- 7827-10-49)

AITKEN, R. J.; HARKISS, D.; BUCKINGHAM, D. W. Analysis of Lipid Peroxidation Mechanisms in Human Spermatozoa. Molecular Reproduction and Development, v. 35, p. 302-315, 1993a.

AITKEN, R. J.; HARKISS, D.; BUCKINGHAM, D. W. Relationship Between Iron-catalysed Lipid Peroxidation Potential and Human Sperm Function. Journal of Reproduction and Fertility, v. 98, p. 257-265, 1993 b.

BAUMAN, D. E. Bovine somatotropin: review of na emerging animal technology. Journal Dairy Science, v.73. n.11, p. 3432-3440, 1992.

BAUMAN, D. E.; CURRIE, W. B. Partitioning of nutrients during Prenhez and lactation: A review of mechanisms involving homeostasis and homeorhesis. Journal of Dairy Science, v. 62 , n. 9 , p. $1514-1528,1980$

BAUMAN, D. E.; GRIINARI, J. M. Nutritional regulation of milk fat synthesis. Annual Review of Nutrition, v. 23, p. 203-227, 2003.

BEAM, S. M.; BUTLER, W. R. Energy balance and ovarian follicle development prior to the first ovulation postpartum in dairy cows receiving three levels of dietary fat. Biology of Reproduction, v. 56, p.133-142, 1997.

BEAM, S. W.; E BUTLER, W. R. Energy balance, jhmetabolic hormones, and early postpartum follicular development in dairy cows fed prilled lipid. Journal of Dairy Science, v. 81 , p. $121-131,1998$

BECONI, M. T.; AFFRANCHINO, M. A.; SCHANG, L. M.; BEORLEGUI, N. B. Influence of Antioxidants on SOD Activity in Bovine Sperm. Biochemistry International, v. 23, n. 3, p. 545-553, 1991. 
BELL, A. W. Regulation of organic nutrient metabolism during transition from late pregnancy to early lactation. Journal of Animal Science, v.73, p. 2804-2819, 1995.

BENDICH, A. Physiological role of antioxidants in the immune system. Journal of Dairy Science, v. 76, p. 2789-2794, 1993.

BERNABUCCI, U.; RONCHI, B.; LACETERA, N.; NARDONE, A. Influence of body condition score on relationships between metabolic status and oxidative stress in periparturient dairy cows. Journal of Dairy Science, v. 88, p. 2017-2026, 2005.

BERTICS, S. J.; GRUMMER, R. R.; CADORNIGA-VALINO, C.; STODDARD, E. E. Effect of prepartum dry matter intake on liver triglyceride concentration in early lactation. Journal of Dairy Science, v. 75, p. 1914-1922, 1992.

BEUTLER, E.; DURON, O.; KELLY, B. M. Improved method for the determination of blood glutatione. Journal Labiratirt Clinical Medicine, v. 61, n. 5, p. 882-888, 1963.

BEUTLER, W. R.; HOEBE, K.; DU, X.; ULEVITCH, R. J. How we detect microbes and respond to them: toll-like receptors and their transducers. Journal of Leukocyte Biology, $\mathrm{v}$. 74, p. 479-485, 2003.

BIRGEL, E. H.; GRUNERT, E. Obstetrícia vetreinária. Sao Paulo: falta editora, 2001. v. 1.

BOBE, G.; YOUNG, J. W.; BEITZ, D. C. Invited review: Pathology, etiology, prevention and treatment of fatty liver in dairy cows. Journal of Dairy Science, v. 87, p. 3105-3124, 2004.

BRADFORD, A.; ATKINSON, J.; FULLER, N.; RAND, R.O. The Efeito of Vitamin E on the Structure of Membrane Lipid Assemblies. Journal of Lipid Research, v. 44, n. 10, p. 1940-1945, 2003.

BRITT, J. H. Impacts of early post partum metabolism on follicular development and fertility. In: ANNUAL FLORIDA RUMINAL NUTRITION SYMPOSIUM, 1992, Orlando, Anais... 1992. p. 39-43.

BUTLER, W. R. Nutritional effects on resumption of ovarian cyclicity and conception rate in postpartum dairy cows. In: 26 Occ Publ Br Soc Anim Sci (ed.) Fertility in the high producing dairy cow. 2001: 133-145.

BUTLER, W. R. Review: Effect of protein nutrition on ovarian and uterine physiology in dairy cattle. J Dairy Sci, v. 81, p. 2533-2539, 1998. 
BUTLER, S. T.; PELTON, S. H.; BUTLER, W. R. Insulin increases $17 \beta$-estradiol production by the dominant follicle of the first posPTartum follicle wave in dairy cows. Reproduction, v. 127 , p. 537-545, 2004.

BUTLER, W. R. Efeito do balanço energético negativo na fertilidade de vacas leiteiras. In: CURSO DE NOVOS ENFOQUES NA PRODUÇÃO E REPRODUÇÃO DE BOVINOS, 7. 2004, Uberlândia. Anais... 2004. p. 101-111

BUTLER, W.R. PRODUÇÃO DE LEITE, BALANÇO ENERGÉTICO NEGATIVO E FERTILIDADE EM VACAS LEITEIRAS. CURSO: Novos Enfoques na Produção e Reprodução de Bovinos. 2008

BUTLER, W.R., SMITH, R. Interrelationships between energy balance and postpartum reproductive function in dairy cattle, Journal Of Dairy Science, v. 72, n. 3, p. 767-783, 1989.

\section{CAMMACK R. OXFORD DICTIONARY OF BIOCHEMISTRY AND MOLECULAR} BIOLOGY. 2 edition.2006

CARSON, M. The association of selected metabolites in peripartum dairy cattle with health and production. MSc dissertation. University of Guelph. 2008.

CARSON, M.; LEBLANC, S.; GOLDEN, S.; CAPEL, M.; OVERTON, M.; SANTOS, J.; LESLIE, K. DUFFIELD, T. Serun non-Esterified fatty acid and Beta-hidroxybutyrate in the transition period and their associantions with disease in dairy cows. Hungarian Veterinary Journal, v. 130, 2008. Supplement, 2.

CASTILLO, C., HERNANDEZ, J., BRAVO, A., LOPEZ-ALONSO, M., PEREIRA, V., BENEDITO, J.L., Oxidative status during late Prenhez and early lactation in dairy cows. Vet. J. 169, 286-292.2005.

CERRI , R. L. A. ; JUCHEM , S. O. ; CHEBEL , R. C.; RUTIGLIANO , H. M. BRUNO , R. G. S. ; GALVÃO, K. N. ; THATCHER, W. W. ; J. E. P. SANTOS, J. E. P. Efeito of fat source differing in fatty acid profile on metabolic parameters, fertilization, and embryo quality in high-producing dairy cows. Journal of Dairy Science, vol. 92, p.1520-1531, 2009

CHANDRA J, SAMALI A, ORRENIUS S., Triggering and modulation of apoptosis by oxidative stress, Free Radic Biol Med. 2000 Aug;29(3-4):323-33

CHIBISA, G. E.; GOZHO, G. N.; VAN KESSEL, A. G.; OLKOWSKI, A. A.; MUTSANGWA, T. Effects of peripartum propylene glycol supplementation on nitrogen metabolism, body composition, and gene expression for the major protein degradation 
pathways in skeletal muscle in dairy cows. Journal of Dairy Science, v. 91, n. 9, p. 3512-27. 2008

CONTRERAS, G.A.; SORDILLO, L. M. Lipid mobilization and inflammatory responses during the transition period of dairy cows. Comparative Immunology, Microbiology and Infectious Diseases, v. 34, p. 281-289, 2011.

COPPOCK, C. E.; WILKS, D. L. Milk yield, and composition Supplemental fat in highenergy rations for lactating cows: Efeitos on Intake, Digestion. Journal Animal Science, v. 69, p. 3826-3837, 1991.

COTE, J.F., HOFF, B. Interpretation of blood profiles in problem dairy herds. The Bovine Practitioner, v. 26, p. 7-11, 1991.

Cozzi, G; Ravarotto, L; Gottardo, F; Stefani, A. L; Contiero, B; Moro, L; Brscic, M and Dalvit, P. Short communication: Reference values for blood parameters in Holstein dairy cows: Effects of parity, stage of lactation, and season of production. Journal of Dairy Science. 94 :3895-3901. doi: 10.3168/jds.2010-3687, 2011

D’ANGELO, L.S. Fontes de gordura na alimentação de vacas leiteiras no período de transição e início de lactação. Dissertação (mestrado). Departamento de Nutrição e Produção Animal. Faculdade de Medicina Veterinária e Zootecnia. Universidade de São Paulo. Pirassununga, SP, 91 f. 2009.

DE WIT, A. A. C.; CESAR, M. L. F.; KRUIP, T. A. M. Effect of urea during in vitro maturation on nuclear maturation and embryo development of bovine cumulus-oocytecomplexes. J. Dairy Sci., v. 84, p. 1800-1804, 2001.

DOEPEL, L.; LAPIERRE, H.; KENNELLY, J. J. Peripartum performance and metabolism of dairy cows in response to prepartum energy and protein intake. Journal Dairy Science, v. 85, p. 2315-2334, 2002.

ĐOKOVIĆ, R., ŠAMANC, H., BOŠKOVIĆ-BOGOSAVLJEVIĆ, S., RADOVIĆ, V. Changes of characteristic blood parameters in ketotic cows. Veterinarski Glasnik,v. 59, suppl. 1-2, p. 221-228, 2005.

DRACKLEY, J. K. Biology of dairy cows during the transition period: The final frontier? Journal of Dairy Science, v. 82, p. 2259-2273, 1999.

DUFFIELD T, LEBLANC S, LESLIE K. Impact of subclinical disease on risk of early lactation culling. Journal of Dairy Science, 2005a; 1:199. 
DUFFIELD, T. F., LISSEMORE, K, D., MCBRIDE, B. W., LESLIE, K.E. Impact of Hyperketonemia in early lactation dairy cows on health and production. Journal of Dairy Science J. Dairy Sci. v. 92, p.571-580, 2009.

DUFFIELD, T., LEBLANC S, LESLIE K. Impact of subclinical metabolic disease on risk of early lactation culling. Journal of Dairy Science. 2005b; 88(Suppl. 1)

DUSKE, K.; HAMMON, H. M.; LANGHOF, A.-K.; BELLMANN, O.; LOSAND, B.; NÜRNBERG, K.; NÜRNBERG, G.; SAUERWEIN, H.; SEYFERT, H. M.; METGES, C. C. Metabolism and lactation performance in dairy cows fed a diet containing rumen-protected fat during the last twelve weeks of gestation. Journal of Dairy Science, v. 92, p. 1670-1684, 2009.

EDMONSON, A. J.; LEAN, I. J.; WEAVER, L. D. et al. A body condition scoring chart for Holstein dairy cows. Journal of Dairy Science, vol.72, n.1, p.68-78, 1989.

ELROD, C. C.; BUTLER, W. R. Reduction of fertility and alteration of uterine pH in heifers fed excess ruminally degradable protein. Journal Animal Science, v.71, p.694- 701, 1993a.

Elrod, C.C., M.E. Van Amburgh, and W.R. Butler (1993b) Alterations of pH in response to increased dietary protein incattle are unique to the uterus. J. Anim. Sci. 71:702-706.

EMERY, R. S.; LIESMAN, J. S.; HERDT, T. H. Metabolism of long chain fatty acids by ruminant liver. Journal of Nutrition, v.122, p.832-839, 1992.

Farrugia A (January 2010). "Albumin usage in clinical medicine: tradition or therapeutic?". Transfus Med Rev 24 (1): 53-63. doi: 10.1016/j.tmrv.2009.09.005. PMID 19962575.

FAUSTMAN, C.; CHAN, W.K.; SCHAEFER, D.M.; HAVENS, A. Beef color update: the role for vitamin E. Journal of Animal Science, v.76, p.1019-1026, 1998

FORMAN HJ, FUKUTO JM, TORRES M. Redox signaling: thiol chemistry defines which reactive oxygen and nitrogen species can act as second messengers. Am J Physiol Cell Physiol. 2004 Aug;287(2):C246-56

FOSSATI, P.; PRENCIPE, L. Serum triglycerides determined colorimetrically with a enzyme that produces hydrogen peroxide. Clinical Chemistry. v.28, p.2077-2080; 1982.

FREITAS JÚNIOR, J. E.; RENNÓ, F. P.; SILVA, L. F. P.; GANDRA, J. R.; MATURANA FILHO, M.; FODITSCH, C.; VENTURLLI, B. C. Parâmetros sanguíneos de vacas leiteiras 
suplementadas com diferentes fontes de gordura. Ciência Rural, v. 40, n. 4, p. 950-956, Revista Brasileira de Zootecnia, v. 30, n. 4, p. 1376-1380, 2010.

GANDRA, J. R. Fontes de ácidos graxos $\omega 3$ e $\omega 6$ em dietas de vacas leiteiras no período de transição e início de lactação. 2012. 170 f. Tese (Doutorado em Ciências) - Faculdade de Medicina Veterinária e Zootecnia, Universidade de São Paulo, Pirassununga, 2012.

Garverick , H. A.; H arris, M .N; Vogel-Bluel , R; Sampson, J.D; Bader , J; Lamberson, W.R; Spain ,* M . C. L ucy, * and R. S. Y oungquist. Concentrations of nonesterified fatty acids and glucose in blood of periparturient dairy cows are indicative of pregnancy success at first insemination. J. Dairy Sci. 96 :181-188 http://dx.doi.org/ 10.3168/jds.2012-5619

Garverick HA. Ovarian follicular cysts in dairy cows. J Dairy Sci 1997;80:995-1004.

GONZÁLEZ F.H.D., DÜRR, J.W., FONTANELI, R.S. (Eds.) Uso do leite para monitorar a nutrição e o metabolismo de vacas leiteiras. Porto Alegre: Universidade Federal do Rio Grande do Sul. 2001. 77p.

GONZÁLEZ, F.H.D. O perfil metabólico no estudo de doenças da produção em vacas leiteiras. Arquivos da Faculdade de Veterinária da UFRGS, v. 25, p. 13-33,1997.

GONZÁLEZ, F.H.D., MUIÑO, R., PEREIRA, V. et al. Indicadores sanguíneos de lipomobilização e função hepática no início da lactação em vacas leiteiras de alta produção. VIII CONGRESSO BRASILEIRO DE BUIATRIA. Belo Horizonte, Brasil, 2009. Anais.

GREGORY, L. Valores parões de referência de parâmetros bioquímicos séricos utilizados na avaliação das funções hepáticas e renal de bovinos da raça Jersey, criados no Estado de São Paulo. Influência dos fatores etários, sexuais e da infecção pelo Vírus da Leucose de Bovinos. 1995. 161f. Dissertação (Mestrado) - Faculdade de Medicina Veterinária e Zootecnia, Universidade de São Paulo, São Paulo, 1995.

GRUMMER, R. R. Etiology of lipid-related metabolic disorders in periparturient dairy cows. Journal of Dairy Science, v.76, p.3882-3893, 1993.

GRUMMER, R. R. Gordura da dieta: Fonte energética e/ou regulador metabólico? In: NOVOS ENFOQUES NA PRODUÇÃO E REPRODUÇÃO DE BOVINOS, 8, 2004, Uberlândia. Anais... Uberlândia: CONAPEC Jr-UNESP-BOTUCATU, p.83-108, 2004.

GRUMMER, R. R. Impact of changes in organic nutrients metabolism on feeding the transition cow. Journal of Animal Science, v.73, p.2820-2833, 1995. 
GRUNERT, E.; BIRGEL, E.H.; VALE, W.G. Patologia e clínica da reprodução dos animais mamíferos domésticos. $1^{\text {a }}$ edição, Livraria Varela, 2005.

GWAZDAUSKAS, F. C.; KENDRICK, K. W.; PRYOR, A. W. et al. Impact of follicular aspiration on folliculogenesis as influenced by dietary energy and stage of lactation. Journal of Dairy Science, v.83, p.1625-1634, 2000.

HAFEZ, E. S. E; HAFEZ, B. Reprodução Animal. Sétima Edição - Editora Manole, 2004.

HALLIWELL, B; GUTTERIDGE, J., M. Free Radicals in Biology and Medicine, $4^{\mathrm{a}}$ ed., Oxford University Press, 2007

HAMMON, D.S., G.R. HOLYOAK, AND T.R. DHIMAN (2005) Association between blood plasma urea nitrogen levels andreproductive fluid urea nitrogen and ammonia concentrations in early lactation dairy cows. Anim. Reprod. Sci.86:195-204.

HATAMOTO, L.K. Efeito do Estresse e da Suplementação com Vitamina E Sobre Parâmetros Espermáticos, Peroxidação Lipídica de Componentes Seminais e Atividade das Enzimas Antioxidantes Presentes no Plasma Seminal de Cães. 2004, 180 f. Tese- Faculdade de Medicina Veterinária e Zootecnia, Universidade de São Paulo, São Paulo, 2004.

HEKIMSOY, ZELIHA; OKTEM, IRIS KAVALALI. SERUM CREATINE KINASE LEVELS IN OVERT AND SUBCLINICAL HYPOTHYROIDISM Endocrine Research, 31(3):171-175, (2005) ISSN 0743-5800 print/1532-4206 online DOI: $10.1080 / 07435800500371706$

HENRIQUES, Laura Cristina Sant'Anna. Perfil metabólico de vacas da raça Holandesa com catarro genital de graus I, II e III entre o final do puerpério clínico e no puerpério tardio, São Paulo e Paraná, Brasil. 2011. Dissertação (Mestrado em Clínica Veterinária) - Faculdade de Medicina Veterinária e Zootecnia, Universidade de São Paulo, São Paulo, 2011. Disponível em: <http://w w w .teses.usp.br/teses/disponiveis/10/10136/tde-06072012-152739/>. Acesso em: 2013-11-16.

HERDT, T. H. Variability characteristics and test selection in herd level nutritional and metabolic profile testing. Veterinary clinics of North America: Food Animal Practice, 16 (2), 387-403, 2000.

HOEDEMAKER, M.; PRANGE, D.; ZERBE, H.; FRANK, J.; DAXENBERGER, A.; MEYER, H. H. D. Peripartal propylene glycol supplementation and metabolism, animal health, fertility, and production in dairy cows. Journal of Dairy Science, v. 87. p. 2136-2145, 2004. 
JORRISTMA, R.; RUBIO POMAR, F. J.; BEVERS, M. M.; KRUIP, T. A. M.;

NOORDHUIZEN, J. P. T. M. Wensing, Th. Possible clues concerning the adverse relationship between dairy cow fertility and negative energy balance. Acta Veterinaria.

Scandinavica. Supplement, 98.2003

JORRITSMA R, CESAR ML, HERMANS JT, KRUITWAGEN CL, VOS PL. Effects of non-esterified fatty acids on bovine granulosa cells and developmental potential of oocytes in vitro. Animal Reproduction Science 81: 225-235. 2004.

KANEKO, J.J.; HARVEY, J.W.; BRUSS, M.L. Clinical biochemistry of domestic animals. $5^{\circ}$ edição, California: Academic Press, 932p., 1997.

KAUFMANN, T.; DRILLICH, M.; TENHAGEN, B.; HEUWIESER, W. Relationship between periparturient serum concentrations of non-esterified fatty acids (nefa), betahidroxybutyrat, bilirubin and urea and the prevalence of postpartum bovine endometritis. Hungarian Veterinary Journal, v. 130, 2008. Supplement, 2.

KIMURA, K.; GOFF, J. P.; KEHRLI, M. E.; REINHARDT, T. A. Decreased neutrophil function as a cause of retained placenta in dairy cattle. Journal Dairy Science, v. 85, p. 544$550,2002$.

KLEPPE, B. B., R. J. AIELLO, R. R. GRUMMER, AND L. E. ARMENTANO. Triglyceride accumulation and very low-density lipoprotein secretion by rat and goat hepatocytes in vitro. J. Dairy Sci. 71:1813-1822. 1988.

KÖNYVES, L.; SZENCI, O.; JURKOVICH, V.; MRS. TEGZES, L.; TIRIÁN, A.; SOLYMOSI, N.; GYULAY, G. Y.; BRYDL, E. Periparturient risk assessments for placenta retention in dairy cow. Hungarian Veterinary Journal, v.130, 2008. Supplement, 2.

Kruip TAM, Meijer GAL, Rukkwamsuk Th, Wensing Th. Investigation into the mechanisms of reduction in fertility of high yielding cows. In 10th Intern. Conf. Production Diseases in Farm Animals. 1998;183-190: Utrecht, The Netherlands.

KRUIP, T. A. M.; MEIJER; G. A. L.; RUKKWAMSUK, T.; WENSING, T. Effects of feeding in the dry period on fertility of dairy cows post partum. Reproduction In Domestic Animals, v. 33, p. 165-168, 1998.

LACETERA, N.; SCALIA, D.; FRANCI, O.; BERNABUCCI, U.; RONCHI, B.; NARDONE, A. Short communication: effects of nonesterified fatty acids on lymphocyte function in dairy heifers. Journal of Dairy Science, v.87, p. 1012-1014, 2004a. 
LEBLANC SJ, HERDT J, SEYMOUR T. Factors associated with peripartum serum concentrations of vitamin $\mathrm{E}$, retinol, and $\beta$-carotene in Holstein dairy cattle, and their associations with periparturient disease. Journal of Dairy Science 2004b; 87:609-619.

LEBLANC, S. MONITORING PROGRAMS FOR TRANSITION DAIRY COWS. XXIV WORLD BUIATRIC CONGRESS. FRANCE.2006

LEBLANC, S.J.; LESLIE, K.E.; DUFFIELD, T.F. Metabolic Predictors of Displaced Abomasum in Dairy Cattle. Journal of Dairy Science, 88,159-170, 2005a.

LEBLANC, S.J; DUFFIELD, T.F; LESLIE, K.E; BATEMAN, K.G; KEEFE, G.P; WALTON, J.S; JOHNSON, W.H. Defining and Diagnosing Postpartum Clinical Endometritis and its Impact on Reproductive Performance in Dairy Cows. Journal of Dairy Science. 85:2223-2236. 2002.

LEHNINGER A. Princípios de bioquímica. 4. ed. São Paulo: Sarvier; 2006.

LEROY JL, VANHOLDER T, MATEUSEN B, CHRISTOPHE A \& OPSOMER G 2005a Non-esterified fatty acids in follicular fluid of dairy cows and their effect on developmental capacity of bovine oocytes in vitro. Reproduction 130 485-495. (doi:10.1530/rep.1.00735)

LEROY, J. L. M. R.; PSOMER, G.; VAN SOOM, A.; GOOVAERTS, I. G. F.; BOLS, P. E. J. Reduced fertility in high yielding dairy cows: are the oocyte and embryo in danger? Part I: The importance of negative energy balance and altered corpus luteum function to the reduction of oocyte and embryo quality in high yielding dairy cows. Review. Reproduction of Domestic Animals, v. 43, p. 612-622, 2008.

LEROY, J. L.; VANHOLDER, T.; DELANGHE, J. R.; OPSOMER, G.; VAN SOOM, A.; BOLS, P. E.; DE KRUIF, A. Metabolite and ionic composition of follicular fluid from different-sized follicles and their relationship to serum concentrations in dairy cows. Animal Reproduction Science, v. 80, p. 201-211, 2004 b.

LEROY, J.; VANHOLDER, T.; MATEUSEN, B.; CHRISTOPHE, A.; OPSOMER, G.; de KRUIF, A.; GENICOT, G.; VAN SOOM, A. Nonesterified fatty acids in follicular fluid of dairy cows and their effect on developmental capacity of bovine oocytes in vitro.

Reproduction. v. 130, p. 485-495, 2005.

LEWIS, K.; MCKAY, D.M. Metabolic stress evokes decreases in epithelial barrier function. Annals of the New York Academy of Sciences. May;1165, p. 327-37, 2009. 
LILLIG CH, BERNDT C, VERGNOLLE O, LÖNN ME, HUDEMANN C, BILL E, HOLMGREN A. Characterization of human glutaredoxin 2 as Fe-S protein a possible role as redox sensor. Proc Natl Acad Sci U S A. 2005 Jun 7;102(23):8168-73. Epub 2005 May 25.

Lopez H, Caraviello DZ, Satter LD, Fricke PM, Wiltbank MC. Relationship between level of milk production and multiple ovulations in lactating dairy cows. J Dairy Sci 2005;88:27832793.

LUCY, Matthew C. Regulation on follicular growth by somatotropin and insulin-like growth factors in cattle. Journal dairy science. V. 83, n.7, p.1635-1647, 2000.

M. C. LUCY. Reproductive Loss in High-Producing Dairy Cattle: Where Will It End? Journal of Dairy Science V. 84, No. 6, 2001

MASHEK, D. G.; BERTICS, S. J.; GRUMMER, R. R. Effects of intravenous triacylglycerol emulsions on hepatic metabolism and blood metabolites in fasted dairy cows. Journal of Dairy Science, v. 88, n. 1, p. 100-109, 2005.

MATURANA FILHO, M. Desempenho produtivo e reprodutivo e parâmetros sanguíneos de vacas leiteiras alimentadas com diferentes fontes de gordura durante o período de transição e inicio de lactação. 2009. 102 f. Dissertação (mestrado) - Faculdade de Medicina Veterinária e Zootecnia da Universidade de São Paulo, São Paulo, 2009.

MATURANA FILHO, M; RENNÓ, F.P; MADUREIRA, E.H, GANDRA, J.R; FREITAS JUNIOR, J.E; BARLETTA, R.V. Dinâmica folicular de vacas leiteiras de 2 ou 3 ondas de crescimento folicular alimentadas com diferentes fontes de ácidos graxos insaturados de cadeia longa no período de transição e início de lactação. 47a Reunião Anual da Sociedade Brasileira de Zootecnia Salvador, BA - UFBA, 27 a 30 de julho de 2010

MCDOWELL, L. R. Minerais para ruminantes sob pastejo em regiões tropicais enfatizando o Brasil. Gainesville, Fl.: University of Flórida, 2000.

MCNAMARA, S.; BUTLER, T.; RYAN, D. P.; MEE, J. F.; DILLON, P.; O’MARA, F. P.; BUTLER, S. T.; ANGLESEY, D.; RATH, M.; MURPHY, J. J. Effect of offering rumen protected fat supplements on fertility performance in spring-calving Holstein-Friesian cows. Animal Reproduction Science, v. 79, p. 45- 56, 2003.

MIKALSEN SO, SANNER T. Increased gap junctional intracellular communication in Syrian hamster embryo cells treated with oxidative agents, Carcinogenesis. 1994 Feb;15(2):381-7. 
MOALLEM, U.; KATZ, M.; ARIELI, A.; LIVSHITZ; YAKOB, Y. S. Effects of peripartum propylene glycol or fats differing in fatty acid profiles on feed intake, production, and plasma metabolites in dairy cows. Journal of Dairy Science, v. 90, p. 3846-3856, 2007.

MULLIGAN F.J., GRADY L.O., RICE D.A., DOHERTY M.L. A herd health approach to dairy cow nutrition and production diseases of the transition cow. Animal reproduction Science, v. 96, p. 331-353, 2006.

NATIONAL RESEARCH COUNCIL - NRC 2001. Nutrient requirements of dairy cattle. 7 ed. Washinton, D.C.: National Academic Press. 381p.

NEJAD, S. G.; CHERAGHI, J. The study of serum leval of glucose, cholesterol, triglyceride, albumin and total protein in repeat breeder native cows in Ahwaz (Iran). Acta Veterinaria Scandinavica, v. 44, p. 124, 2003. Supplement, 1, doi:10.1186/1751- 0147-44-S1-P124. Disponível em: <http://www.actavetscand.com/content/44/S1/P124>.

NICHI, M. Sistemas de Proteção Enzimática e Níveis de Peroxidação Espontânea dos Lipídios Seminais de Touros Zebuínos e Taurinos Criados a Campo na Região de Dourados, MS. 2003, 101 f. Dissertação (Mestrado) - Faculdade de Medicina Veterinária e Zootecnia, Universidade de São Paulo, São Paulo, 2003.

OETZEL, G. R. Monitoring and testing dairy herds for metabolic diseases. Veterinary Clinics of North America. Food Animal Practice, Philadelphia, v. 20, p. 651-674,2004

OSPINA, P.A.; NYDAM , D.V.; STOKOL, T.; OVERTON, T.R. Evaluation of nonesterified fatty acids and $\beta$-hydroxybutyrate in transition dairy cattle in the northeastern United States: Critical thresholds for prediction of clinical diseases. Journal of Dairy Science. v. 93, p. 546-554, 2010.

OVERTON, T. R.; DRACKLEY, J. K.; OTTEMANN-ABBAMONTE, C. J. SubstTaxa utilization for hepatic gluconeogenesis is altered by increased Glicose demand in ruminants. Journal of Animal Science, v. 77, p. 1940-1951, 1999.

OVERTON, T. R.; WALDRON, M. R. Nutritional management of transition dairy cows: strategies to optimize metabolic health. Journal of Dairy Science, v. 87, p. 105-119, 2004, Supplement, E.

PAYNE, J.M., DEW, S.M., MANSTON, R., FAULKS, M. The use of metabolic test in dairy herds. Veterinary Record, v. 87, p. 150-157, 1970. 
PEETERS, E.; NEYT, A.; BECKERS, F.; DE SMET, S.; AUBERT, A.E.; GEERS, R. Influence of supplemental magnesium, tryptophan, vitamin $C$, and vitamin $E$ on stress responses of pigs to vibration. Journal of Animal Science, v.83,p.1568-1580, 2005.

Pursley JR, Mee MO, Wiltbank MC. Synchronization of ovulation in dairy cows using PGF $2 \alpha$ and GnRH. Theriogenology 1995;44:915-923.

RAJALA-SCHULTZ, P.J., SAVILLE, J.A., FRAZER, G.S., WITTUM, T.E. Association between milk urea nitrogen and fertility in Ohio dairy cows. Journal of Dairy Science v. 84, p. 482-489, 2001.

Rhoads, M. L; Rhoads, R. P, Gilbert, R.; Toole, R. and Butler, W. R (2006) Detrimental effects of high plasma urea nitrogen levels on viability of embryos from lactating dairy cows. Anim.Reprod.Sci. 91:1-10.

RIVERA, J. D.; DUFF, G.C.; GALYEAN, M.L.; WALKER, D.A.; NUNNERY, G.A. Efeitos of supplemental vitamin $\mathrm{E}$ on performance, health, and humoral immune response of beef cattle. Journal of Animal Science, v.80, p.933-941, 2002.

ROCHA, D. R; ARAÚJO, A.A.; MOURA, A.A.A.N; SALES, M.G.F. Avaliação de estresse térmico em vacas leiteiras mestiças (Bos taurus x Bos indicus) durante os períodos chuvoso e seco no Estado do Ceará. $\mathbf{4 5}^{\circ}$ Reunião anual da Sociedade Brasileira de Zootecnia. P.13.2008 .

RONCHI B, STRADAIOLI G, VERINI SUPPLIZI A, BERNABUCCI U, LACETERA N, ACCORSI PA, NARDONE A, SEREN E. Influence of heat stress or feed restriction on plasma progesterone, oestradiol-17ß, LH, FSH, prolactin and cortisol in Holstein heifers. Livest Prod Sci 2001;68:231-241.

ROSSATO W., GONZÁLEZ F.H.D., DIAS M.M., FARIA S.V., RICCÓ D. Condição metabólica e desempenho reprodutivo no pós-parto em vacas leiteiras do sul do Brasil. Revista Brasileira de Reprodução Animal, v.23, p.155-156, 1999.

RUKKWAMSUK, T.; KRUIP, T. A. M.; GERWIN, A. L.; MEIJER, ??; WENSING, T. Hepatic Fatty Acid Composition in Periparturient Dairy Cows with Fatty Liver Induced by Intake of a High Energy Diet in the Dry Period. Journal Dairy Science, v. 82, p. 280- 287, 1999.

SAUT, JOÃO PAULO ELSEN. Influência do puerpério e da retenção dos anexos fetais no proteinograma de fêmeas bovinas da raça Holandesa, criadas no Estado de São Paulo. 2008. Tese (Doutorado em Clínica Veterinária) - Faculdade de Medicina Veterinária e Zootecnia, 
Universidade de São Paulo, São Paulo, 2008. Disponível em: <http://w w w .teses.usp.br/teses/disponiveis/10/10136/tde-28052008- 141522/>. Acesso em: 2013-05-31.

Schlattner, U; Forstner, M; Eder, M; Stachowiak, O; Fritz-Wolf, K; Wallimann, T Functional aspects of the X-ray structure of mitochondrial creatine kinase: a molecular physiology approach, Mol. Cell. Biochem. 184 (1998) 125-140.

SHAVER, R. D. Nutritional risk factors in the etiology of left displaced abomasums in dairy cows: A review. Journal of Dairy Science.80:2449-2453. 1997

SHELDON, I. M.; DOBSON, H. Postpartum uterine health in cattle. Animal Reproduction Science, v. 82-83, p. 295-306, 2004.

SHELDON, I. M.; NOAKES, D. E.; RYCROFT, A. N.; DOBSON, H. Acute phase protein response to postpartum uterine bacterial contamination in cattle. The Veterinary Record, v. 148, p. 172-175, 2001.

SMITH, B.P. Medicina Interna dos Grandes Animais, $3^{\text {a }}$ edição, Manole, 2006.

SORDILLO LM, AITKEN SL.. Impact of oxidative stress on the health and immune function of dairy cattle. Vet Immunol Immunopath 2009; 128:104-109.

SORDILLO, L. M.; SHAFER-WEAVER, K.; DEROSA, D. Immunobiology of the mammary gland. Journal of Dairy Science, v. 80, n. 8, p. 1851-1865, 1997.

SOUZA, Regiane Machado de. Avaliação da função hepática e do lipidograma no período puerperal e pós-puerperal e suas inter-relações com os distúrbios reprodutivos de fêmeas bovinas da raça Holandesa, criadas no Estado de São Paulo. 2005. Dissertação (Mestrado em Clínica Veterinária) - Faculdade de Medicina Veterinária e Zootecnia, Universidade de São Paulo, São Paulo, 2005. Disponível em: <http:// w w w.

teses.usp.br/teses/disponiveis/10/10136/tde-19102006-115359/>. Acesso em: 2013-05-31.

SPICER, L. J.; TUCKER, W. B.; ADAMS, G. D. Insulin-like growth factor-I in dairy cows: relationships among energy balance, body condition, ovarian activity, and estrous behavior. Journal of Dairy Science, vol.73, p.929-937, 1990.

STAPLES, C. R.; BURKE, J. M.; THATCHER, W. W. Optimizing energy nutrition for reproducing dairy cows: Influence of supplement fats on reproductive tissues and performance of lactating cow. Journal of Dairy Science, v. 81, p. 856-871, 1998.

STAPLES, C. R.; WILTBANK, M. C.; GRUMMER, R. R.; GUENTHER, J.; SARTORI, R.; DIAZ, F. J.; BERTICS, S.; MATTOS, S.; THATCHER, W. W. Effect of long chain fatty 
acids on lactation performance and reproductive tissues of Holstein cows. Journal of Dairy Sience, v. 83, p. 278, 2000. Supplement 1.

STATISTICAL ANALYSIS SYSTEM - SAS. SAS OnlineDoc. Version 9.3. Cary: SAS Institute, 2011. (CD-ROM).

STEFANON, B., SGORLON, S., GABAI, G., 2005. Usefulness of nutraceutics in controlling oxidative stress in dairy cows around parturition. Vet. Res.Commun. 29 (Suppl. 2), 387-390.

STEVENSON, J. S. A review of oestrous behaviour and detection in dairy cows. In: Fertility in the high producing dairy cow. Occ Publ Br Soc Anim Sci 2001;26:43-62.

STRANG, B. D.; BERTICS, S. J.; GRUMMER, R. R. et al. Efeito of long-chain fatty acids on triglycerides accumulation, gluconeogenesis, and ureagenesis in bovine hepatocytes.

Journal of Dairy Science, vol.81, p.728-739, 1998.

SUGIO S , KASHIMA A , MOCHIZUKI S , NODA M , KOBAYASHI K (June 1999). "Crystal structure of human serum albumin at 2.5 A resolution.". Protein Engineering 12 (6): 439-446. doi:10.1093/protein/12.6.439. PMID 10388840.

SURIYASATHAPORN, W., HEUR, C., NORDHUIZEN-STASSEN, E.N.,SCHUKKEN, Y.H., Hyperketonemia and the impairment of udder defense: A review.Vet. Res. 31:397-412. 2000 .

SUTTLE, N.F., JONES, D.G., 1989. Recent developments in trace element metabolism and function: trace elements. Disease resistance and immune responsiveness in ruminants.

Journal of Nutrition. 119, 1055-1061.

SUZUKI, T; MATSUURA, T; OHKAWA, K; MIYAMURA, T; OKAZAKI, I; WATANABE, T; SUZUKI, T (July 2006). "All-trans retinoic acid down-regulates human albumin gene expression through the induction of C/EBPbeta-LIP". Biochem J. 397 (2): 34553. doi:10.1042/BJ20051863.PMC 1513275. PMID $\underline{\text { 16608438. }}$.

TAMMINGA, S., LUTEIJN, P. A., MEIJER, R. G. M. Changes in composition and energy content of liveweight loss in dairy cows with time after parturition. Livestock Production Science, vol.52, p.31-38, 1997.

THATCHER, W. W.; WILCOX, C. J. Post partum estrus as an indicator of reproductive status in the cow. Journal of Dairy Science, v. 56, p. 608-610, 1973.

VAN DEN TOP, A.M., GEELEN, M.J.H., WENSING, T., WENTINK, G.H.,VAN'T KLOOSTER, A.T., BEYNEN, A.C., Higher posPTartum hepatic triacylglycerol 
concentrations in dairy cows with free rather than restricted access to feed during the dry Período are associated with lower activities of hepatic glycerolphosphate acyltransferase. J. Nutr. 126:76-851996.

VAN HOECK V, STURMEY RG, BERMEJO-ALVAREZ P, RIZOS D, GUTIERREZADAN A, et al. (2011) Elevated Non-Esterified Fatty Acid Concentrations during Bovine Oocyte Maturation Compromise Early Embryo Physiology. PLoS ONE 6(8): e23183. doi:10.1371/journal.pone.0023183

VAN HOECK V, VALCKX S \& BOLS PEJ 2012 Intrafollicular conditions as a major link between maternal metabolism and oocyte quality: a focus on dairy cow fertility. Reproduction, Fertility, and Development 24 1-12 (invited review). (doi:10.1071/RD11901)

VAN HOECK,V; LEROY, J.L; ARIAS ALVAREZ, M; RIZOS, D; GUTIERREZ-ADAN, A; SCHNORBUSCH, K ; BOLS, P. E. J; LEESE, H.J AND STURMEY, R. G; Oocyte developmental failure in response to elevated nonesterified fatty acid concentrations: mechanistic insights Reproduction (2013) 145 33-44 DOI: 10.1530/REP-12-0174 Reproduction and Fertility

VAN KNEGSEL, A. T.; VAN DEN BRAND, H.; DIJKSTRA, J.; TAMMINGA, S.; KEMP, B. Effect of dietary energy source on energy balance, production, metabolic disorders and reproduction in lactating dairy cattle. Reprodoction Nutrition Development,v.45, p. 665$88,2005$.

VANDEHAAR, M. J.; YOUSIF, G.; SHARMA, B. K.; HERDT, T. H.; EMERY, R. S.; ALLEN, M. S.; LIESMAN, J. S. Effect of energy and protein density of prepartum diets on fat and protein metabolism of dairy cattle in the periparturient period. Journal of Dairy Science, v. 82, n. 6, p. 1282-1295, 1999.

WALSH, R, LEBLANC, S, DUFFIELD, T, LESLIE, K Retrospective analysis of the association between subclinical ketosis and conception failure in Ontario dairy herds Proc World Buiatrics Congress/ Med Vet Quebec 34:152. 2004

WALSH, R. B.; KELTON, D.F.; DUFFIELD, T.F.;LESLIE, K.E.;. WALTON, J.S.; LEBLANC, S.J. Prevalence and Risk Factors for Post partum Anovulatory Condition in Dairy Cows Journal of Dairy Science V. 90, No. 1, 2007

WASHBURN SP, SILVIA WJ, BROWN CH, MCDANIEL BT, MCALLISTER AJ. Trends in reproductive performance in southeastern Holstein and Jersey DHI herds. J Dairy Sci 2002;85:244-251.

WEBB, R.; GARNSWORTHY, P. C.; CAMPBELL, B. K.; HUNTER, M. G. Intra-ovarian regulation of follicular development and oocyte competence in farm animals.

Theriogenology, v. 68S, p. S22-S29, 2008. 
WEBB, R.; NICHOLAS, B.; GONG, J. G.; CAMPBELL, B. K.; GUTIERREZ, C. G.; GARVERICK, H. A.; ARMSTRONG, D. G. Mechanisms regulating follicular development and selection of the dominant follicle. Reproduction Supplment, v. 61, p. 71-90, 2003.

WILTBANK, M. Factors affecting reproductive efficiency in U.S dairy herds. NOVOS ENFOQUES NA PRODUÇÃO E REPRODUÇÃO DE BOVINOS, 10, Uberlândia. Anais, p. 3- 9, 2006

WILTBANK, M.; LOPEZ, H.; SARTORI, R.; SANGSRITAVONG, S.; GUMEN, A. Changes in reproductive physiology of lactating dairy cows due to elevated steroid metabolism. Theriogenology, v. 65, p. 17-29, 2006.

WILTBANK, M.C; GUMEN, A; SARTORI, R. PHYSIOLOGICAL CLASSIFICATION OF ANOVULATORY CONDITIONS IN CATTLE.Theriogenology 57:21-52, 2002 0093-691X

WILTBANK, MILO. Novos estudos sobre cistos foliculares e outras condições anovulatórias. NOVOS ENFOQUES NA PRODUÇÃO E REPRODUÇÃO DE BOVINOS, 8 Uberlândia. Anais. 2004.

WITTWER, F. Diagnóstico dos desequilíbrios metabólicos de energia em rebanhos bovinos In: GONZALEZ, F. H. D.; BARCELLOS, J. O.; OSPINA, H.; RIBEIRO, L. A. O. (Ed.) Perfil metabólico em ruminantes: seu uso em nutrição e doenças nutricionais. Porto Alegre: Gráfica da Universidade federal do Rio Grande do Sul, p. 9- 22, 2000.

ZACHUT, M; HONIG, H; STRIEM, S; ZICK, Y; BOURA-HALFON, S AND MOALLEM, U. Periparturient dairy cows do not exhibit hepatic insulin resistance, yet adipose-specific insulin resistance occurs in cows prone to high weight loss J. Dairy Sci. 96 :5656-5669 http://dx.doi.org/10.3168/jds.2012-6142, 2013 